EFFECTS OF POTENTIAL GEOTHERMAL DEVELOPMENT IN THE CORWIN SPRINGS KNOWN GEOTHERMAL RESOURCES AREA, MONTANA, ON THE THERMAL FEATURES OF YELLOWSTONE NATIONAL PARK

Michael L. Sorey, Editor

U.S. GEOLOGICAL SURVEY

Water-Resources Investigations Report 91-4052

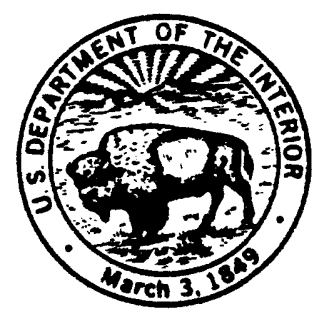

Menlo Park, California 


\section{U.S. DEPARTMENT OF THE INTERIOR}

MANUEL LUJAN, JR., Secretary

U.S. GEOLOGICAL SURVEY

Dallas L. Peck, Director

For additional information write to:

Regional Hydrologist

U.S. Geological Survey

345 Middlefield Road, MS 470

Menlo Park, CA 94025
Copies of the report can be purchased from: U.S. Geological Survey

Books and Open-File Reports Section

Federal Center, Bldg. 810

Box 25425

Denver, Colorado 80225 


\section{Contents}

Abstract

Chapter A. Summary and Conclusions

by Michael L. Sorey

Chapter B. Introduction

by Michael L. Sorey

Chapter C. Geologic Setting of the Corwin Springs Known Geothermal Resources Area-Mammoth Hot Springs Area in and Adjacent to Yellowstone National Park

by Kenneth L. Pierce, Kenneth D. Adams, and Neil C. Sturchio

Chapter D. Electrical Geophysical Investigations in The Norris-Mammoth Corridor, Yellowstone National Park, and the Adjacent Corwin Springs Known Geothermal Resources Area by William D. Stanley, Donald B. Hoover, and Michael L. Sorey

Chapter E. Soil Mercury and Streambed-Temperature Anomalies in the Norris-Mammoth-La Duke Corridor

by W.L. Hamilton and R.L. Chambers

Chapter F. Geochemical Investigations of Hydraulic Connections Between the Corwin Springs Known Geothermal Resources Area and Adjacent Parts of Yellowstone National Park by Yousif K. Kharaka, Robert H. Mariner, Thomas D. Bullen, B. Mack Kennedy, and Neil C. Sturchio

Chapter G. Hydrologic Investigations in the Corwin Springs Known Geothermal Resources Area and Adjacent Parts of Yellowstone National Park

by Michael L. Sorey, Elizabeth M. Colvard, D.A. Nimick, R.R. Shields, J.J. Thordsen, and Gil Ambats

Chapter H. Effects of Potential Geothermal Development

by Michael L. Sorey

\section{Illustrations}

Figure A-1. Map showing Corwin Springs Known Geothermal Resources Area -

Yellowstone National Park study area and principal areas of hotspring discharge

Figure A-2. Map of the Mammoth Hot Springs area in Yellowstone National Park ..................A-4

Figure A-3. Conceptual 3-dimensional model of flow systems associated with thermal areas in and adjacent to Yellowstone National Park

Figure A-4. Geologic sections in the Mammoth-La Duke area 
Figure A-5. Map showing important structures in the Roaring MountainMammoth-La Duke area

Figure B-1. Map showing Corwin Springs Known Geothermal Resources Area -

Yellowstone National Park study area and principal areas of hotspring discharge

Figure B-2. Map showing topography of the study area in and adjacent to Yellowstone National Park

Figure C-1. Map showing geology of the Norris-Mammoth-La Duke area in and adjacent to Yellowstone National Park

Figure C-2. Geologic sections in the Mammoth-La Duke area

Figure C-3. Columnar section of pre-Cenozoic rocks in the study area

Figure C-4. Map showing important structures in the Roaring MountainMammoth-La Duke area

Figure C-5. Composite longitudinal section along the Yellowstone River valley and up the Gardner River valley showing altitudes of volcanic deposits and the upper limit of glaciation

Figure C-6. Map showing location of postulated glacial scour basin extending from Gardiner to below La Duke Hot Springs

Figure C-7. Schematic east-west section showing possible relation between Norris - Mammoth corridor and East Gallatin fault

Figure C-8. Map showing ages of travertine deposits and their relation to structures in the Mammoth - La Duke area

Figure D-1. Map showing locations of magnetotelluric soundings and model profiles in the study area

Figure D-2. Graph showing example magnetotelluric sounding from location 20

Figure D-3. Detailed two-dimensional models for magnetotelluric profiles $\mathrm{AA}^{\prime}$ and BB'

Figure D-4. Map showing the location of telluric traverses and inferred faults

Figure D-5. Graph showing multifrequency telluric voltage data for the western part of traverse 1

Figure D-6. Graphs showing multifrequency telluric voltage data for traverse 5 D-14

Figure D-7. Graph showing multifrequency telluric voltage data for traverse line 7 D-16

Figure E-1. Map of the study area showing soil mercury traverses and summed mercury anomaly amplitudes

Figure E-2. Graph of a portion of the Black Arrow (BA) traverse showing soil mercury concentrations associated with faults.

Figure E-3. Map of the study area showing contours of mercury background concentrations

Figure E-4. Graph showing streambed-temperature anomalies on the east bank of the Gardner River in the Chinese Garden - Hot River area near Mammoth Hot Springs

Figure E-5. Map showing soil-mercury traverses and streambed-temperature stations near Hot River

Figure E-6. Map showing streambed thermal-anomaly zones on the Gardner and Yellowstone Rivers between the Hot River area and the north boundary of Yellowstone National Park. 
Figure E-7. Map showing locations of streambed-thermal anomaly zones and mercury anomalies in the Gardiner airport area

Figure E-8. Map showing locations of streambed-thermal anomaly zones and mercury anomalies near La Duke Hot Spring.

Figure F-1. Location map showing the regional setting for the Norris-Mammoth corridor and selected springs and wells in the Mammoth Hot Springs area

Figure F-2. Location map showing the distribution of travertine deposits and locations of the $\mathrm{Y}-10$ well and selected thermal springs

Figure F-3. Graphs showing concentration of $\mathrm{B}, \mathrm{Br}$ and $\mathrm{Li}(\mathrm{a})$, and the $\mathrm{Br} / \mathrm{Cl}$ weight ratios (b) as a function of $\mathrm{Cl}$ concentrations in thermal waters from the study area.

Figure F-4. Trilinear diagrams showing the percentage proportions of major cations and anions.

Figure F-5. Graph showing the $\delta \mathrm{D}$ and $\delta^{18} \mathrm{O}$ values of selected thermal waters F-12

Figure F-6. Graph showing permil deviations in the ${ }^{36} \mathrm{Ar}{ }^{\mu 0} \mathrm{Ar}$ ratios of gas samples

Figure F-7. Graph showing relation between ${ }^{87} \mathrm{Sr} /{ }^{86} \mathrm{Sr}$ ratios and $\mathrm{Sr} / \mathrm{Cl}$ weight ratios

Figure F-8. Graph showing the $\delta^{11} \mathrm{~B}$ values and concentrations of $\mathrm{B}$ in selected thermal waters.

Figure G-1. Map of the Mammoth Hot Springs area in Yellowstone National Park showing hydrologic monitoring sites and thermal features.

Figure G-2. Map of the Corwin Springs Known Geothermal Resources Area and adjacent parts of Yellowstone National Park showing wells and springs

Figure G-3. Graphs showing hydrologic-monitoring data for Mammoth Outflow G-7

Figure G-4. Graphs showing hydrologic-monitoring data for Hot River. G-8

Figure G-5. Graph showing hydrologic monitoring data from continuous monitoring system on Hot River

Figure G-6. Graphs showing chloride-flux values at four sites along or adjacent to the Gardner River below Mammoth Hot Springs

Figure G-7. Chart showing well construction, temperature, lithologic, and flowmeter data for well Y-10 at Mammoth Hot Springs G-14

Figure G-8. Graphs showing hydrologic-monitoring data for La Duke Hot Springs G-16

Figure G-9. Chart showing well construction, temperature, and flow-meter data for Church Universal and Triumphant (CUT) geothermal well, Royal

Teton Ranch Spring Creek well, and Miller geothermal well near La Duke Hot Spring G-18

Figure G-10 Maps showing the area around Bear Creek Springs in the Corwin Springs Known Geothermal Resources Area (A) and Sheepeater Canyon Hot Spring in Yellowstone National Park (B) G-23

Figure H-1. Conceptual model of possible flow systems associated with thermal areas in and adjacent to Yellowstone National Park 


\section{Tables}

Table C-1. Travertine deposits and active hot springs......................................................................36

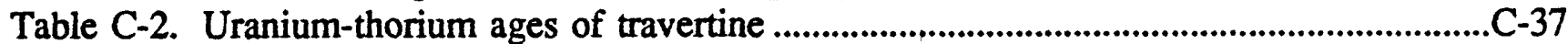

Table F-1. Chemical composition of water from selected springs and wells ...............................F-32

Table F-2. Water and solute isotopes from selected springs and wells ....................................F-33

Table F-3. Chemical compositions of dissolved gases in thermal springs and wells.................F-34

Table F-4. Chemical and isotopic compositions of gas from gas discharges ..................................35

Table F-5. Isotopic values for selected rock, travertine, and mineral samples .............................F-36

Table F-6. Subsurface temperature calculated from selected chemical geothermometers

Table F-7. Calculated possible amounts of Mammoth-type thermal water in that of La Duke Hot Spring and Bear Creek-1

Table G-1. Hydrologic monitoring data for Mammoth Outflow ....................................................-27

Table G-2. Hydrologic monitoring data for Hot River ..................................................................30

Table G-3. Hydrologic monitoring data for La Duke Hot Spring..............................................34

Table G-4. Values of thermal-water discharge in the vicinity of La Duke Hot Spring .............G-38

Table G-5. Selected data for wells in Corwin Springs Known Geothermal Resources

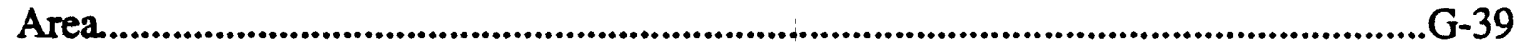

Table G-6. Total discharge of Clearwater Springs .................................................................-40

Table G-7. Partial chemical analyses for spring BC-1 at Bear Creek Springs in the Corwin Springs Known Geothermal Resources Area and for Sheepeater Canyon Hot Spring in Yellowstone National Park. 


\section{Conversion Factors, Vertical Datum, and Abbreviations}

$\underline{\text { Multiply }}$

bar

meter (m)

kilometer $(\mathrm{km})$

liter per second $(\mathrm{L} / \mathrm{s})$

meter squared per second $\left(\mathrm{m}^{2} / \mathrm{s}\right)$
By

0.0000145

3.281

0.6214

15.85

10.8

12,500
To obtain

pounds per square inch (psi)

foot $(\mathrm{ft})$

mile (mi)

gallons per minute (gal/min)

foot squared per second $\left(\mathrm{ft}^{2} / \mathrm{s}\right)$

gallons per day per foot $(\mathrm{gpd} / \mathrm{ft})$

Other abbreviations used:

$\delta$ - standard delta notation (isotopic ratios)

$\%$ - parts per thousand, or per mil (isotopic ratios)

ka - thousand years ago

$\mathrm{Ma}$ - million years ago

$\mathrm{mg} / \mathrm{L}$ - milligrams per liter (chemical concentration)

$\mu \mathrm{S} / \mathrm{cm}$ - microsiemens per centimeter at $25^{\circ} \mathrm{C}$ (specific electrical conduction)

ppm - parts per million

$\mathrm{ppb}$ - parts per billion

RSD - relative standard deviation; (standard deviation $\div$ mean) $\times 100 \%$

$\mathrm{TU}$ - tritium units; one atom of tritium in $10^{18}$ hydrogen atoms

$\mathrm{W} / \mathrm{m}^{2}$ - watts per meter squared (heat flow)

Temperature is given in degrees Celsius $\left({ }^{\circ} \mathrm{C}\right)$, which can be converted to degrees Fahrenheit $\left({ }^{\circ} \mathrm{F}\right)$ by the following equation:

$$
\text { Temp. }{ }^{\circ} \mathrm{F}=1.8\left(\text { temp. }{ }^{\circ} \mathrm{C}\right)+32
$$

"Sea level" refers to the National Geodetic Vertical Datum of 1929 (NGVD of 1929)--a geodetic datum derived from a general adjustment of the first-order level nets of both the United States and Canada, formerly called "Sea Level Datum of 1929."

Terms used:

The hydraulic head in a reservoir is given by the height of the water column above an arbitrary datum in a well tapping an aquifer. Hydraulic head is related to fluid pressure by the equation:

Hydraulic head $=$ (pressure/specific gravity $)+$ elevation above arbitrary datum

Alkaline earth metals - elements whose oxides form mildly alkaline solutions; $\mathrm{Ca}, \mathrm{Mg}, \mathrm{Be}, \mathrm{Ba}, \mathrm{Sr}$, Ra.

Alluvium - deposits resulting from the operation of modern rivers. 
Aquifer - a permeable formation that stores and transmits ground water in sufficient quantity to supply wells.

Basalt - a dark extrusive rock composed primarily of calcium-, magnesium-, and iron-rich minerals. Basement fault - a fault that extends into basement rocks.

Basement rocks - a complex of metamorphic and igneous rocks that underlies the sedimentary formations.

Bedrock - any solid rock exposed at the surface or overlain by unconsolidated material.

${ }^{14} \mathrm{C}$ age - the age of an object or a rock unit as determined by the amount of radioactive decay of its carbon-14 isotope.

Caldera - a large, circular depression in a volcanic terrain, typically caused by explosion, collapse, or erosion.

Conservative chemical - Constituent of thermal water that is useful as a naturally occurring tracer because once dissolved by high-temperature rock/water interaction its concentration is unchanged by subsequent passage through the flow system.

Dedolomitization - The alteration of dolomite $\left(\mathrm{MgCO}_{3}\right)$ to form calcite $\left(\mathrm{CaCO}_{3}\right)$ and magnesium $(\mathrm{Mg})$.

Dike - a tabular body of rock formed by the intrusion of magma, cutting across the structure of adjacent rocks.

Dip - the angle at which a stratum is inclined from the horizontal. At right angle to the strike.

Footwall - the mass of rock beneath a fault plane.

Geothermometer - method for determining the maximum temperature of an underground system.

Glacial erratic - a large rock transported by glacial ice.

Graben - a block that has been downthrown along faults relative to the rocks on either side.

Horst - a block that has been uplifted along faults relative to the rocks on either side.

Hot spring - thermal spring that is warmer than body temperature $\left(37^{\circ} \mathrm{C}\right)$

Hydraulic connection - a continuous permeable zone (aquifer) between thermal areas through which thermal fluid is being transmitted by a positive gradient in hydraulic head.

Hydrogeologic connection - a continuous permeable zone (aquifer) between thermal areas that could transmit thermal fluid if a positive gradient in hydraulic head exists.

Hydrothermal system - circulation of meteoric water from a recharge area to depths where heat is supplied by some combination of regional crustal heat flow and magmatic sources, then upward to eventual discharge at or near the land surface.

Isothermal - having equal degrees of heat.

Lithology - the mineral composition and texture of a rock.

Lacustrine - pertaining to, produced, or formed by lakes.

Laramide - a period of major earth deformation lasting from approximately 136 - 37 million years ago.

Meteoric water - water derived from the atmosphere.

Meteoric water line - the linear correlation between ${ }^{2} \mathrm{H}$ and ${ }^{18} \mathrm{O}$ concentrations obtained from precipitation surveys.

Morphology - the form and structure of a surface.

Noble gas - an inert or chemically non-reactive gas. Includes $\mathrm{He}, \mathrm{Ar}$, and $\mathrm{Ra}$.

Normal fault - a high-angle fault in which the block above the fault has moved downward relative to the block below.

Piezometric surface - the surface to which the water from a given aquifer will rise under its full head. 
Quaternary - The most recent geologic time period (2 Ma to present). Subdivided into two epochs: Pleistocene (2-0.01 Ma) and Recent (0.01 Ma to present).

Radiogenic - formed as a consequence of radioactive decay.

Reverse fault - a high-angle fault in which the block above the fault has moved upward relative to the lower block.

Rhyolite - a light colored extrusive rock composed of silica-, aluminum-, sodium-, and potassiumrich minerals.

Scarp - an escarpment, cliff, or steep slope.

Slickenside - polished surface with parallel grooves that results from friction along a fault plane. Slough - a place of deep mud or mire.

Storage Coefficient - a dimensionless measure of the water released from storage due to compression of the reservoir rock and expansion of water per unit volume and unit decline of head.

Stratigraphic - consisting of mainly sedimentary rocks that are grouped for description.

Strike - the bearing of the horizontal line formed by the intersection of an inclined stratum or fault plane with the earth's surface.

Strike ridge - a ridge that is parallel to the strike of nearby rock units.

Syncline - a large fold whose limbs are higher than its center.

Tectonic - pertaining to structures formed by large scale deformation of the earth's crust.

Telluric - pertaining to the depths of the earth.

Thermal spring - spring whose water has a temperature more than $\sim 10^{\circ} \mathrm{C}$ above the mean annual temperature of the atmosphere in the vicinity of the spring $\left(4^{\circ}-5^{\circ} \mathrm{C}\right.$ in the Mammoth Hot Springs -Corwin Springs KGRA area).

Thrust fault - a low angle reverse fault; the block above the fault has moved up and over the block below the fault.

Transmissivity - a measure of the volumetric flow rate of ground water per unit width of reservoir for a unit hydraulic gradient. It is equal to reservoir hydraulic conductivity times reservoir saturated thickness.

Travertine - calcium carbonate rock deposited from solution in ground and surface waters.

Warm spring - thermal spring that is cooler than body temperature $\left(37^{\circ} \mathrm{C}\right)$. 


\title{
EFFECTS OF POTENTIAL GEOTHERMAL DEVELOPMENT IN THE CORWIN SPRINGS KNOWN GEOTHERMAL RESOURCES AREA, MONTANA, ON THE THERMAL FEATURES OF YELLOWSTONE NATIONAL PARK
}

\author{
Michael L. Sorey, Editor
}

\begin{abstract}
A two-year study by the U.S. Geological Survey, in collaboration with the National Park Service, Argonne National Laboratory, and Los Alamos National Laboratory was initiated in 1988 to determine the effects of potential geothermal development in the Corwin Springs Known Geothermal Resources Area (KGRA), Montana, on the thermal features of Yellowstone National Park. Congressional directive for the study is under Sec. 8 (a) of the Geothermal Steam Act Amendments accompanying Public Law 100-443. The Corwin Springs KGRA is adjacent to the northern boundary of the Park, and includes the towns of Gardiner and Corwin Springs, Montana. Hot springs discharge in the KGRA at and near La Duke Hot Spring and Bear Creek Springs; the nearest known hot springs in the Park are located at and near Mammoth Hot Springs, approximately $14 \mathrm{~km}$ (kilometers) southeast of La Duke Hot Spring and $8 \mathrm{~km}$ south of Bear Creek Springs.

Potential development of geothermal resources in the Corwin Springs KGRA would involve thermal water at temperatures less than about $80^{\circ} \mathrm{C}$ (Celsius) for direct-use applications. In April 1986 the Church Universal and Triumphant (CUT) drilled a 140-m(meter)-deep well in the KGRA across the Yellowstone River from La Duke Hot Spring. Pumping of this well at $25 \mathrm{~L} / \mathrm{s}$ for 13 hours in September 1986 resulted in a significant reduction in the flow of La Duke Hot Spring. No production of geothermal fluids has occurred in the KGRA since that time and geothermal leasing activities were suspended on public lands surrounding the Park in 1988.

Our study addressed three principal issues: (1) the sources of thermal water in the hot springs at Mammoth, La Duke, and Bear Creek, (2) the degree of subsurface connection between these areas, and (3) the effects of geothermal development in the Corwin Springs KGRA on the Park's thermal features. Our investigations included, but were not limited to, geologic mapping, electrical geophysical surveys, chemical sampling and analyses of waters and rocks, determinations of the rates of discharge of various thermal springs, and hydrologic tracer tests. A related investigation of mercury concentrations in shallow soils and streambed temperatures in the Yellowstone and Gardner Rivers was conducted by the National Park Service. The study area extended from the Norris Geyser Basin at the south to the northern end of the Corwin Springs KGRA at the north. Although additional useful information could have come from drilling and testing new wells, such work was beyond the scope and authorization of this study.

We used the results of geologic mapping, determinations of the ages of hot-spring travertine deposits, and geophysical surveys to assess the likelihood that permeable flow paths exist between thermal areas in the Park and in the KGRA. Comparisons of thermal-water chemistry were used to determine whether or not thermal water actually flows from one area to another. Distances and travel times for flow between thermal areas were too great to be detected by more direct injection of chemical tracers, except for sites within the Mammoth Hot Springs area itself.
\end{abstract}


Our results indicate that there could be flow paths between Mammoth Hot Springs and La Duke Hot Spring, but there is no chemical evidence that such flow is actually occurring. There is, however, chemical evidence of a small component of Mammoth-type thermal water in Bear Creek Springs and evidence of substantially greater flow in the past $(>12,000$ years ago) between Mammoth and other parts of the KGRA. The apparent lack of flow from Mammoth to La Duke could be due either to geologic barriers or to the existing distribution of hydraulic head in subsurface reservoirs. In the latter case, large-scale geothermal development in the Corwin Springs KGRA that caused substantial head changes could result in decreased discharge of thermal springs in Yellowstone National Park.

Decreases in discharge of thermal features in the Mammoth Hot Springs area can be avoided by limiting development to (1) the natural flow of La Duke Hot Spring $(7 \mathrm{~L} / \mathrm{s})$, (2) the use of downhole heat exchangers in wells, and under certain conditions (3) fluid production from wells at rates less than the total natural rate of outflow of thermal water into the Yellowstone River in the La Duke and Bear Creek areas. We estimate these total natural discharge rates to be about $60 \mathrm{~L} / \mathrm{s}$ and $17 \mathrm{~L} / \mathrm{s}$, respectively. Under development option (3), it is necessary that production be obtained from the same reservoir that supplies the natural thermal-water outflow so that there is a reduction in this outflow that is close to the rate of well production.

Fluid production from the existing geothermal well drilled by the Church Universal and Triumphant near La Duke Hot Spring at rates up to about $25 \mathrm{~L} / \mathrm{s}$ most likely meets these criteria, and therefore, poses no discernible risk of decreased discharge of the Park's thermal springs. Production from any additional wells that might be drilled in the La Duke area would also not cause adverse effects on the Park's thermal springs, provided the combined production from all wells was less than about $60 \mathrm{~L} / \mathrm{s}$ and each well obtained most of its production by capturing natural thermalwater discharge. Determinations that the latter condition is met could be more difficult to make for these wells than for the existing CUT geothermal well.

A production-rate limit close to $17 \mathrm{~L} / \mathrm{s}$ for wells drilled near Bear Creek Springs could prevent adverse effects on Mammoth Hot Springs, but would result in a decrease in the natural thermalwater outflow into the Yellowstone River in the Bear Creek area. Such a change could be viewed as an adverse effect on the Park's thermal features because this thermal-water discharge occurs adjacent to and partly within the Park boundary. For the region between Bear Creek Springs and La Duke Hot Spring, additional information from well drilling is needed before a production-rate limit can be specified to prevent adverse effects on the Park's thermal features.

Geothermal development anywhere in the Corwin Springs KGRA involving well production at rates exceeding the natural thermal-water outflow could cause more substantial reservoir head changes that would tend to spread toward the Mammoth Hot Springs area, provided permeable flow paths exist. In this case, a monitoring system with observation wells located near the Park boundary could provide early detection of the spread of head changes away from the development area and thereby reduce the risk of decreases in discharge of the Park's thermal springs. Additional subsurface information is needed, however, to enable such observation wells to be properly sited and completed. 


\title{
CHAPTER A
}

\section{SUMMARY AND CONCLUSIONS}

\author{
By Michael L. Sorey
}

\section{Contents}

Introduction

La Duke and Bear Creek Systems.......................................................................................A-8

\section{Introduction}

Scientific investigations were done by the U.S. Geological Survey from 1988 to 1990, in collaboration with the National Park Service, Argonne National Laboratory, and Los Alamos National Laboratory, to determine the effects of potential geothermal development in the Corwin Springs Known Geothermal Resources Area (KGRA), Montana, on the thermal features in Yellowstone National Park. Congressional directive for the study is under Sec. 8 (a) of the Geothermal Steam Act Amendments accompanying Public Law 100-443. The Corwin Springs KGRA is adjacent to the northern boundary of the Park, and includes the towns of Gardiner and Corwin Springs, Montana (fig. A-1). Thermal-water discharges in the KGRA at and near La Duke Hot Spring and Bear Creek Springs; the nearest known hot springs in Yellowstone National Park are located at and near Mammoth Hot Springs, approximately $14 \mathrm{~km}$ southeast of La Duke Hot Spring and $8 \mathrm{~km}$ south of Bear Creek Springs.

Potential development of geothermal resources in the Corwin Springs KGRA would involve production of thermal water at temperatures less that about $80^{\circ} \mathrm{C}$ for direct-use applications. In April 1986, the Church Universal and Triumphant (CUT) drilled a 140-m-deep well on the Royal Teton Ranch directly across the Yellowstone River from La Duke Hot Spring. Pumping of this well at $25 \mathrm{~L} / \mathrm{s}$ for 13 hours in September 1986 resulted in a significant reduction in the flow of La Duke Hot Spring. No production of geothermal fluids has occurred in the KGRA since that time. Public and governmental concerns over the potential effects on thermal features in Yellowstone National Park from long-term production from this well and other such wells that might be drilled in the Corwin Springs KGRA led to suspension of geothermal leasing activities on public lands surrounding the Park in 1988.

Our study addressed three principal issues: (1) the sources of thermal water in the hot springs 


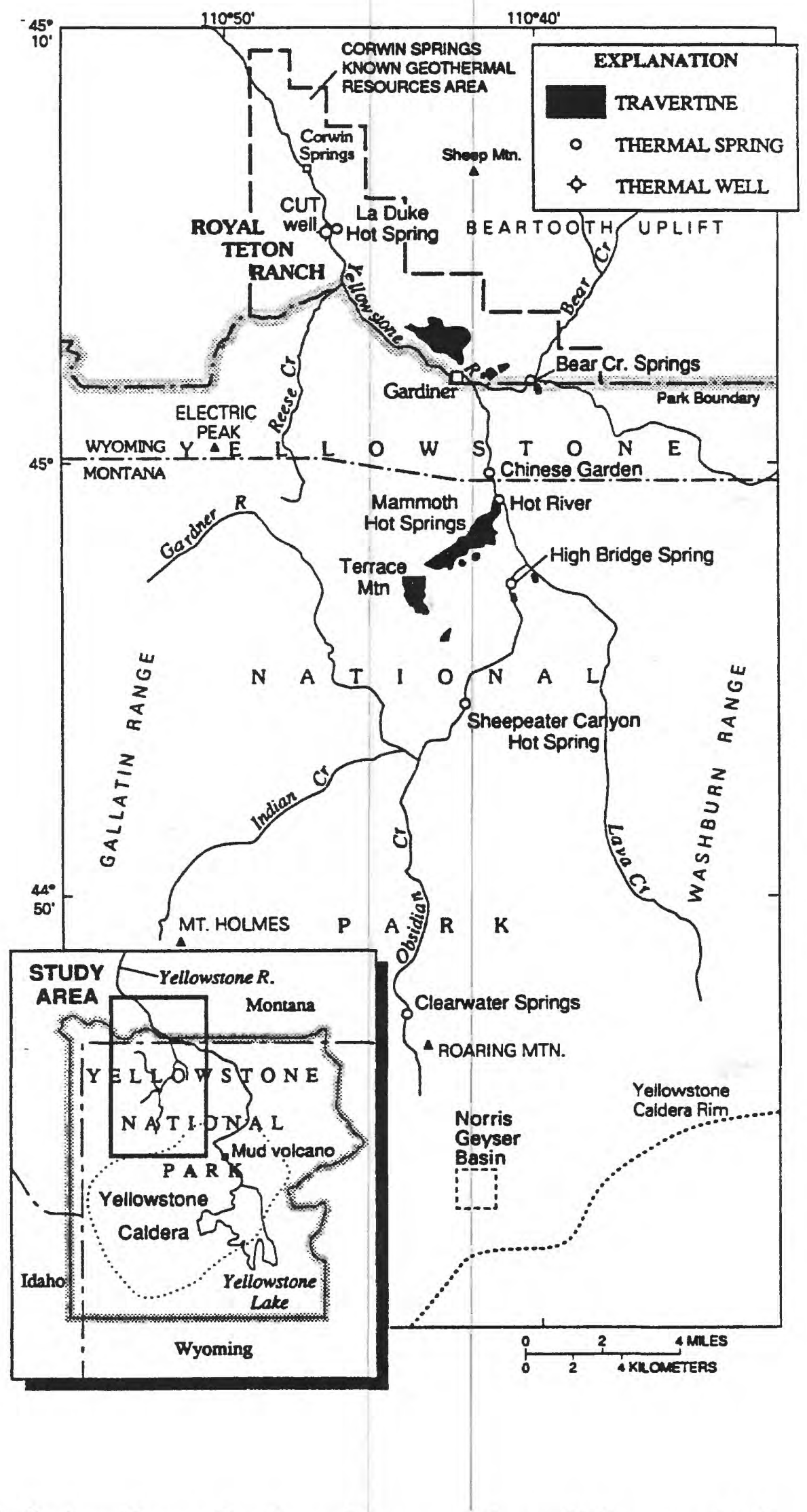

Figure A-1. Corwin Springs Known Geothermal Resources Area - Yellowstone National Park study area showing areas of hot-spring discharge noted in text and the gecthermal well drilled by the Church Universal and Triumphant (CUT well) on the Royal Teton Ranch. 
at Mammoth, La Duke, and Bear Creek, (2) the degree of subsurface connection between Mammoth and La Duke and between Mammoth and Bear Creek, and (3) the effects of geothermal development in the Corwin Springs KGRA on thermal features in Yellowstone National Park. In 1988-1990, geologic, geophysical, and geochemical investigations were done to provide data useful in addressing these issues. This chapter of the report presents a summary of our findings and conclusions of the study. Subsequent chapters of the report present more detailed discussions of the scientific findings. The report provides an appraisal of existing conditions and an assessment of potential effects of geothermal development based on information available as of 1990. Although additional useful information could have come from drilling and testing new wells, such work was beyond the scope and authorization of this study.

Our study focused on potential effects of development on thermal features in the Mammoth area. However, the entire Park is currently listed as a significant thermal feature in the Federal Register notice of August 3,1987. Strictly speaking, changes in head in thermal aquifers located inside the park boundary could be viewed as an adverse effect to be considered following the guidelines set forth in Geothermal Steam Act Amendments accompanying Public Law 100-443. One potential effect of such a change is a decrease in thermal-water discharge to the Yellowstone River in the vicinity of Bear Creek Springs where the river is inside or adjacent to the Park boundary.

The investigations done in this study include geologic mapping, electrical geophysical surveys, geochemical sampling and analyses, hydrologic tracer tests, and monitoring of the discharge characteristics of thermal springs. The U.S. Geological Survey was assisted in some of these investigations by the National Park Service, Argonne National Laboratory, and Los Alamos National Laboratory. In addition, the National Park Service conducted surveys of soil-mercury concentrations and streambed-temperature anomalies. Data were collected from thermal and nonthermal springs and wells in the study area, which extended from the Norris Geyser Basin at the south to the northern end of the Corwin Springs KGRA at the north (fig. A-1). Lack of information from wells on hydrologic conditions at depths greater than about $150 \mathrm{~m}$ limits our ability to delineate specific flow paths for thermal water within the study area, and requires us to use more indirect methods to meet our study objectives.

Critical to a determination of effects of potential geothermal development in the Corwin Springs KGRA on thermal features in Yellowstone National Park are the concepts of hydrogeologic connections and hydraulic connections. By hydrogeologic connections we mean continuous permeable zones, or flow paths, between thermal areas through which fluid could potentially flow from one area to another, provided that a positive gradient in hydraulic head existed. By a hydraulic connection we mean that such a gradient does exist and that fluid does flow from one area to the other. We used results from geologic mapping, travertine-age determinations, electrical geophysical surveys, and soil-mercury and streambed-temperature measurements to assess the likelihood that hydrogeologic connections exist between thermal areas in the Park and the Corwin Springs KGRA. The existence of hydraulic connections was evaluated mainly from the results of the geochemical and isotopic investigations, although tracer tests established that there is a hydraulic connection between the Mammoth Terraces and thermal features along the Gardner River in the vicinity of and including Hot River (fig. A-2). 


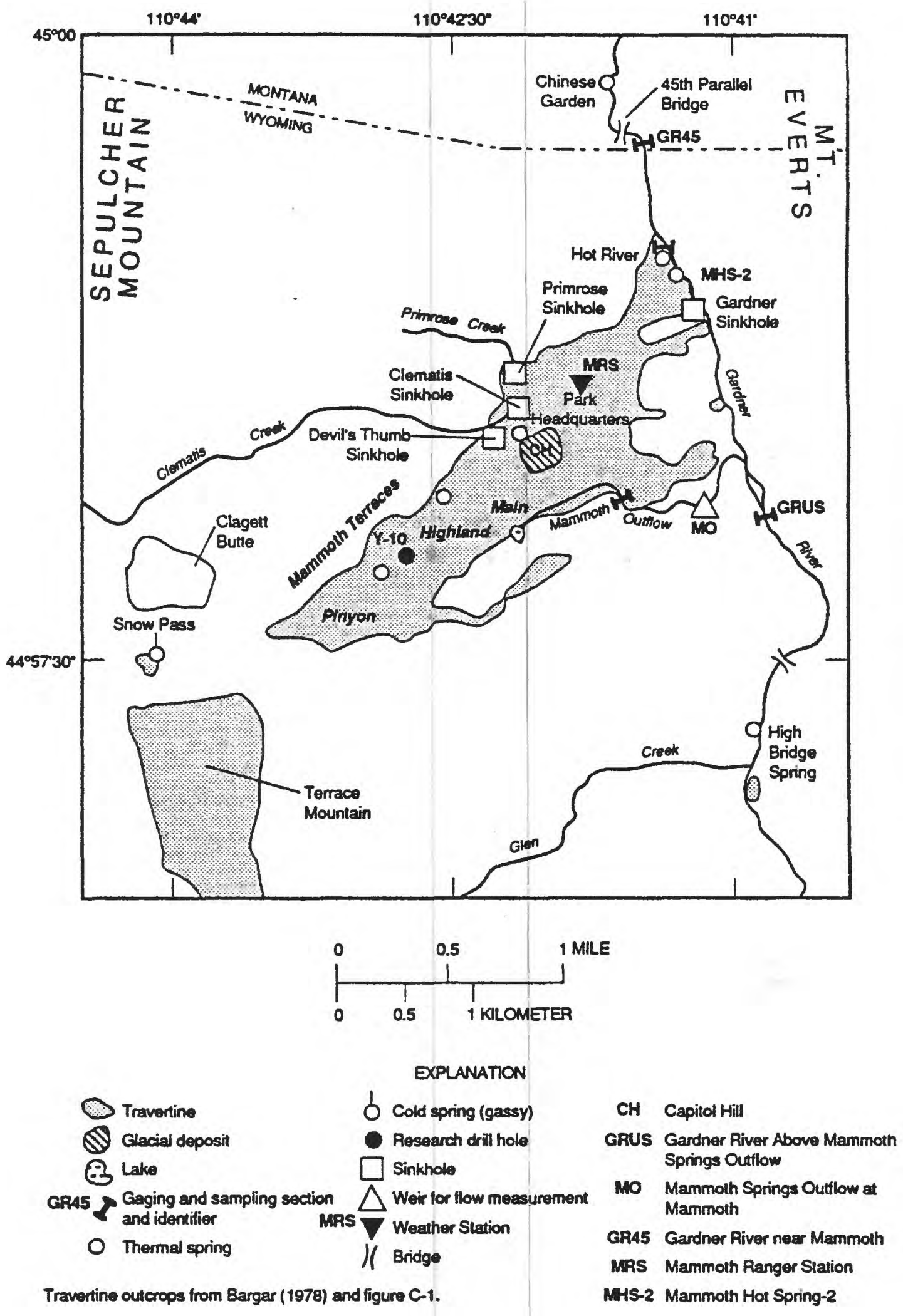

Figure A-2. Mammoth Hot Springs area in Yellowstone National Park showing locations of hydrologic monitoring sites, selected thermal features, and outcrops of travertine. 


\section{Sources of Thermal Water}

Detailed comparisons were made of the chemical and isotopic characteristics of thermal waters from Norris Geyser Basin, Clearwater Springs, Mammoth Hot Springs, Bear Creek Springs, and La Duke Hot Spring (fig. A-1). The dominant chemical signature of thermal waters from these areas changes from a volcanic reservoir-rock influence (with $\mathrm{Na}, \mathrm{Cl}$, and $\mathrm{SiO}_{2}$ the principal dissolved constituents) at Norris and Clearwater to increasing sedimentary reservoir-rock influence (with $\mathrm{Ca}$, $\mathrm{HCO}_{3}$, and $\mathrm{SO}_{4}$ the principal dissolved constituents) moving northward to Mammoth and the Corwin Springs KGRA.

A common feature of hydrothermal systems at Mammoth Hot Springs, Bear Creek Springs, and La Duke Hot Spring is flow through pre-Cretaceous sedimentary rocks in the Gardiner syncline (fig. A-3), where reservoirs for thermal fluids and sources of dissolved chemicals are most likely provided by Paleozoic carbonate rocks, such as the Mississippian Mission Canyon Limestone (Pierce and others, this volume). Stratigraphic and hydrologic relations favor an overall south-to-north direction for ground-water flow in the syncline from Mammoth toward the Gardiner fault. Reservoir temperature estimates based on chemical geothermometers are consistent with such a flow system, ranging from $100^{\circ} \mathrm{C}$ for Mammoth thermal water to $80^{\circ} \mathrm{C}$ for $\mathrm{La}$ Duke and $70^{\circ} \mathrm{C}$ for Bear Creek thermal waters (Kharaka and others, this volume). Minimum depths of fluid circulation required to reach these temperatures range from $2-3 \mathrm{~km}$. The Paleozoic carbonate rocks occur at such depths under the Sepulcher structural low west of Mammoth and beneath the Yellowstone River valley between Bear Creek and La Duke (fig. A-4).

\section{Mammoth Hot Springs System}

Hot-spring discharge from the Mammoth hydrothermal system totals $590 \mathrm{~L} / \mathrm{s}$, approximately 10 percent of which flows from springs in the Mammoth Terraces. Most of the remaining 90 percent flows into the Gardner River from the vent at Hot River. Mammoth thermal water is derived from some combination of lateral flow moving northward in the Norris-Mammoth corridor and deep circulation originating from more local sources (for example, the Gallatin Range to the west). Chemical and isotopic evidence for each of these possibilities is discussed by Kharaka and others (this volume). Similar ratios of conservative constituents, relatively high $\mathrm{Cl}$, and shifts in oxygen-18 from the meteoric-water line in thermal waters at Norris, Clearwater, and Mammoth are consistent with a 30-40 percent component of Norris water in Mammoth thermal water. However, differences in the rates and compositions of gas discharge from Mammoth Hot Springs and thermal areas between Mammoth and Norris could indicate a source of magmatic volatiles (and heat) independent of the main Yellowstone hydrothermal system. Kharaka and others (this volume) suggest a separate magmatic source beneath Mammoth Hot Springs because the highest helium isotope ratios, gas discharges, and heat fluxes are obtained there.

The most significant aspect of the Mammoth hydrothermal system is its rate of heat and fluid discharge. The rate of convective heat output $\left(2.5 \times 10^{8} \mathrm{~W}\right)$, together with elevated helium-isotope ratios, indicate that magmatic heating occurs somewhere in the Mammoth flow system. However, heat-balance calculations show that it is not possible to provide this rate of heat input in a localized flow system of limited areal extent $\left(<100 \mathrm{~km}^{2}\right)$, unless a long-lived magma chamber exists at relatively shallow depths beneath the Mammoth area, or fluid circulation extends down to depths on the order of 10 kilometers. Similar heat-balance calculations applied to a flow of high- 


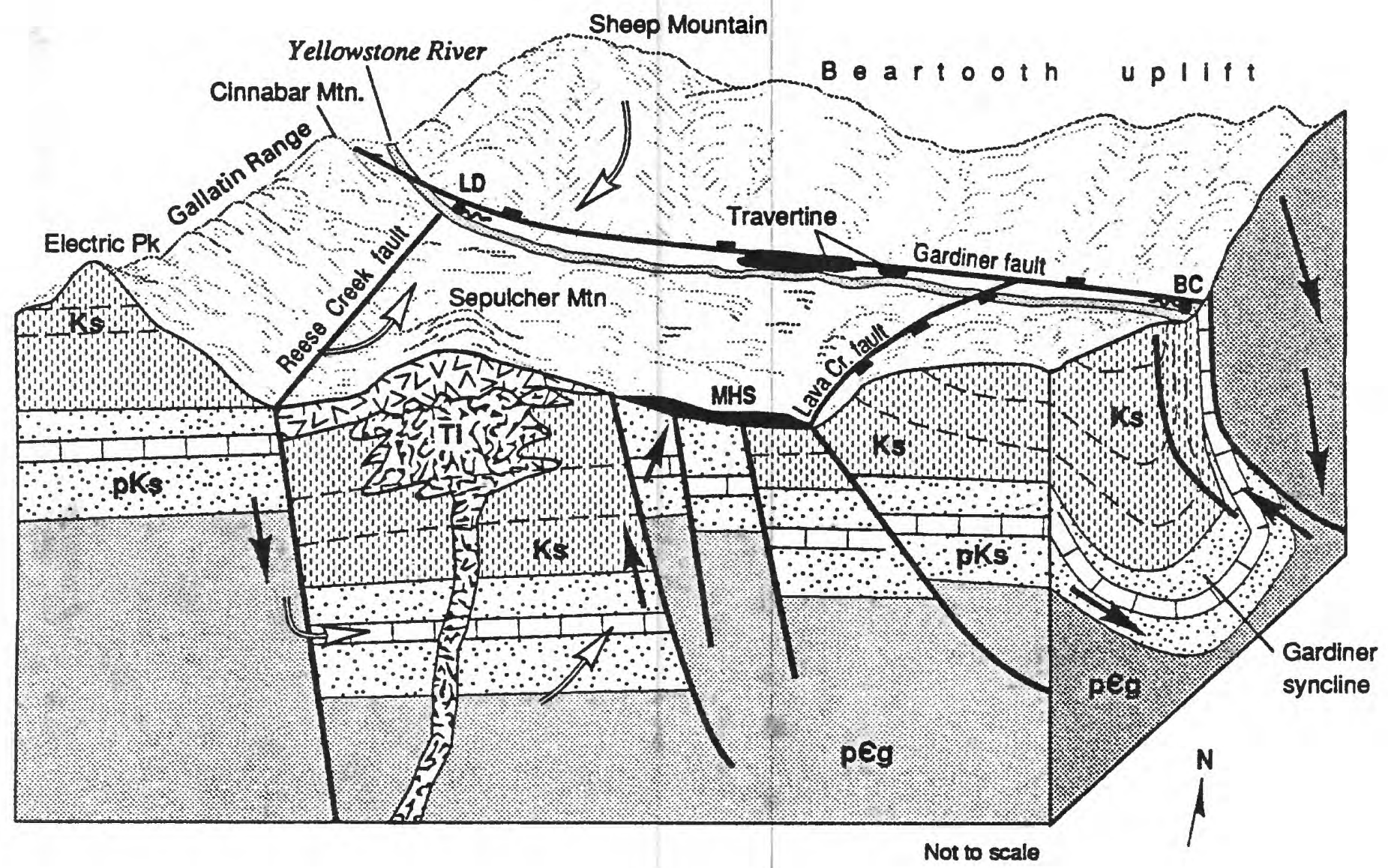

Figure A-3. Conceptual model of possible flow systems associated with thermal areas at Mammoth Hot Springs (MHS), Hot River (HR), Bear Creek Springs (BC), and La Duke Hot Spring (LD). Arrows indicate general directions of fluid flow (solid in exposed planes of the diagram and open along zones unseen in exposed planes of the diagram). Faults shown as heavy solid lines, with block teeth on overriding plate of reverse faults. Simplified stratigraphic units are labeled Ks (Cretaceous sedimentary rocks), pKs (pre-Cretaceous sedimentary rocks), Tvc (Tertiary volcaniclastic rocks), Ti (Tertiary intrusives), and $\mathrm{p} € \mathrm{~g}$ (Precambrian gneiss and schist). Approximate position of the Mississippian Mission Canyon Limestone, a regionally continuous aquifer, is shown by blocky pattern. 


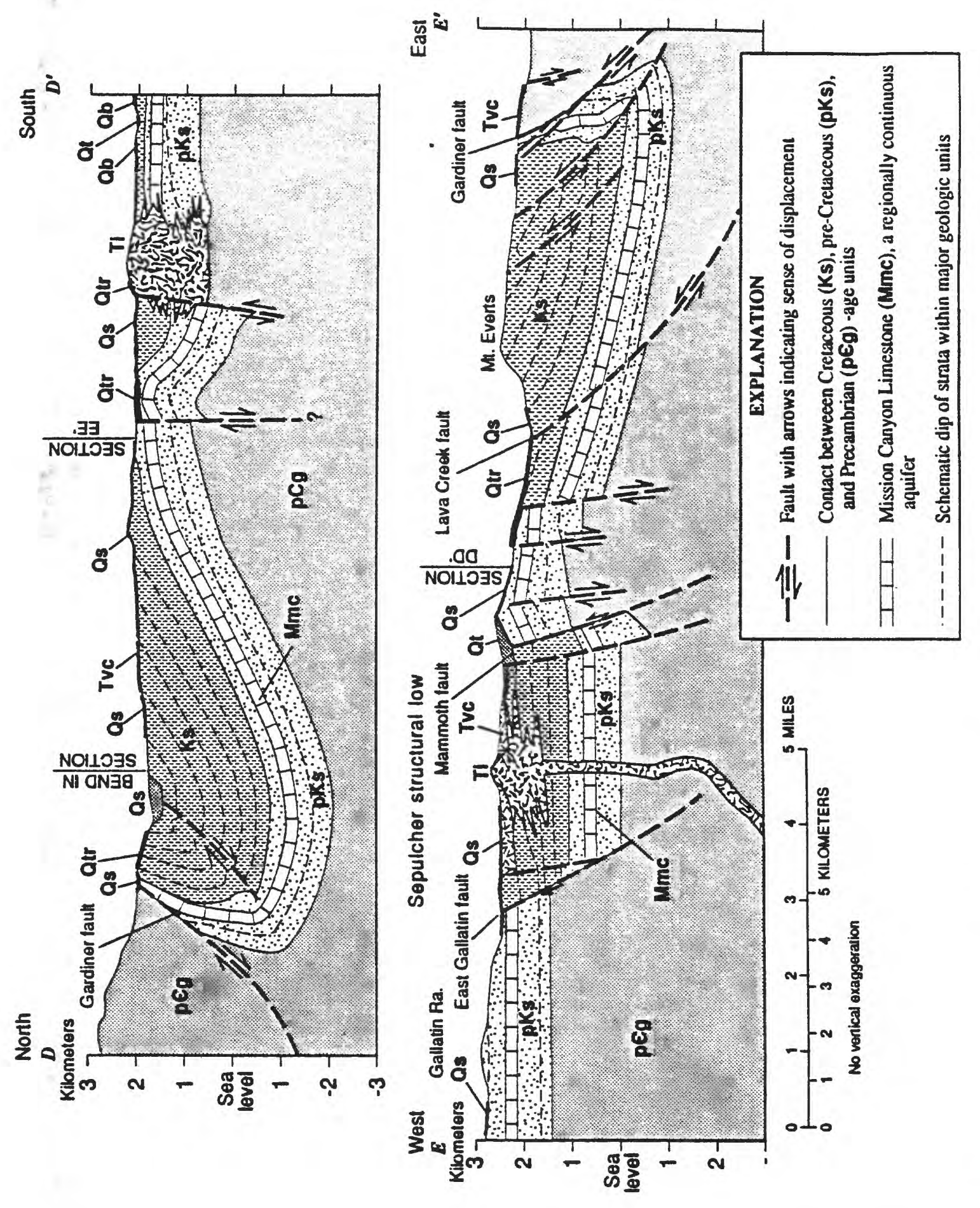

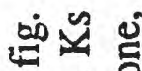

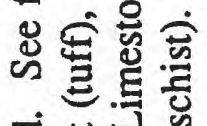

ఫ்

를

淽

월율

월 总

을 츨 종

응 응

तै त्रु

볼

䒕苟岂

드월ㄹㄹㄹ

퓰

을 응 흘

들

틍 ज

연 닐 은

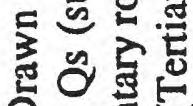

ด 롤

ษึ 몽

늘 矛

뽈

ด. 일.

ษ

홍. 널

을 馬总

E.

$\sum \pi$ 告氙

¿ थ कิ ए

.5 ยู

는을

융 包?

边的

. 드응

응

응 豆?

-

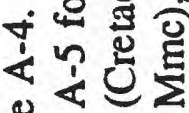

总 
temperature $\left(300^{\circ} \mathrm{C}\right)$ thermal water from the Norris area to Mammoth indicate that most of the heat and about 40 percent of the fluid for the Mammoth system could originate from Norris, provided flow from Norris to Mammoth occurred in permeable zones at depths sufficient to minimize conductive cooling $(2-3 \mathrm{~km})$. These mixing proportions are consistent with those indicated by the conservative constituent ratios noted above.

Interpretations of electrical geophysical soundings indicate that partial-melt conditions $\left(500^{\circ}\right.$ $600^{\circ} \mathrm{C}$ ) exist at depths below about $6 \mathrm{~km}$ in the Norris-Mammoth corridor south of Bunsen Peak (fig. A-5; Stanley and others, this volume). Deep resistivities are generally much higher north of Bunsen Peak, although the sounding data indicate low resistivity at depths below $10 \mathrm{~km}$ in the Mammoth area that could also be related to partial-melt conditions (Stanley and others, this volume). Taken together, the geophysical results and the heat-balance considerations favor a component of flow in the Mammoth system originating from southerly sources in the Norris-Mammoth corridor, although not necessarily from as far south as Roaring Mountain or Norris as postulated by White and others (1988) and Fournier (1989).

Upflow of thermal fluid beneath the Mammoth area may be associated with conduits provided by the Mammoth fault or the Swan Lake fault west of Terrace Mountain or other north-south trending faults to the east of Terrace Mountain (Pierce and others, this volume). Similarities in strontium isotope ratios of travertine in older deposits at Terrace Mountain, Snow Pass, and Pinyon Terrace and those of the active terraces at Mammoth indicate that present-day discharge at Mammoth and Hot River is derived by lateral flow of thermal water from upflow zone(s) located to the west of the active spring vents.

\section{La Duke and Bear Creek Systems}

The discharge rate of La Duke Hot Spring averages $7 \mathrm{~L} / \mathrm{s}$. The flow of the three principal vents at Bear Creek Springs totals 5-10 L/s. Additional thermal water of chemical composition similar to these hot springs discharges into the Yellowstone River from springs and seeps at river level at each area. The total thermal-water discharge, calculated from four measurements of sulfate flux in the river at sites upstream and downstream from La Duke, ranged from 49 to $67 \mathrm{~L} / \mathrm{s}$. A single set of sulfate-flux measurements in the Bear Creek area indicated a total thermal water discharge of $17 \mathrm{~L} / \mathrm{s}$. The total discharge in the La Duke area exceeds the production rate of the CUT geothermal well $(25 \mathrm{~L} / \mathrm{s})$, but is less than the temporary water right to La Duke Hot Spring held by the Church Universal and Triumphant $(328 \mathrm{~L} / \mathrm{s})$.

Several conceptual models are possible for flow systems and reservoir rocks supplying thermal water to La Duke Hot Spring and Bear Creek Springs. These include (1) flow from the south along permeable zones associated with the northward-trending East Gallatin-Reese Creek fault system and other north and northeast-trending faults, (2) flow from the south through Paleozoic carbonate rocks within the gently dipping southern limb of the Gardiner syncline, and (3) flow from the north and east through Precambrian rocks of the Beartooth uplift and/or from more local sources within the Gardiner fault or the vertical limb of the Gardiner syncline. Geochemical data indicate that thermalwater chemistry at La Duke and Bear Creek is influenced by low-temperature $\left(<100^{\circ} \mathrm{C}\right)$ interactions with carbonate rocks and Precambrian metamorphic rocks. Both types of rocks occur in the vicinity of the Gardiner reverse fault and the vertical limb of the Gardiner syncline, so that the chemical characteristics of these thermal waters could be attainable from a flow system localized along the 
Gardiner fault. However, heat-balance considerations based on total thermal-water discharge estimates of 61 and $17 \mathrm{~L} / \mathrm{s}$ for the La Duke and Bear Creek areas, respectively, indicate that the areal extents of flow systems supplying these features are more regional in scale $\left(\sim 100 \mathrm{~km}^{2}\right)$.

Geochemical and isotopic data are useful in assessing the likelihood of hydraulic connections between thermal features in the KGRA and at Mammoth, as discussed below, but do not allow us to clearly delineate actual flow paths and recharge areas for each hydrothermal system. For example, the stable water-isotope data set for the KGRA thermal waters is consistent with recharge in the Gallatin Range or the Beartooth uplift. Oxygen-isotope values for the KGRA thermal waters are not shifted from the meteoric-water line, whereas values for thermal water from Mammoth Hot Springs are. This lack of oxygen shift could be due either to long residence-time flow through the Precambrian rocks of the Beartooth uplift and short residence-time flow through carbonate rocks in upflow zones adjacent to the Gardiner fault, or to lower reservoir temperatures in hydrothermal systems supplying thermal features in the KGRA (Kharaka and others, this volume). In the vicinity of La Duke Hot Spring, thermal springs with similar water chemistry are aligned along segments of the Reese Creek fault system, indicating that intersections of these north-trending faults with the vertical limb of the Gardiner syncline or the Gardiner fault are important in localizing and transmitting upflow through the fine-grained valley fill deposits (Pierce and others, and Hamilton and Chambers, this volume).

Geologic considerations favor permeable zones for deep fluid circulation in the Paleozoic carbonate rocks of the Gardiner syncline and along fault zones such as the Reese Creek fault system rather than in the metamorphic rocks of the Beartooth uplift. Evidence of intense hydrothermal alteration along the Reese Creek fault south of La Duke Hot Springs near the Park boundary, seen in the electrical-sounding data, is indicative of thermal water flowing northward along permeable zones associated with this fault from recharge areas in the Gallatin Range inside the Park to the La Duke area.

\section{Connections Between Thermal Areas}

Hydrogeologic connections between the Mammoth area and the Corwin Springs KGRA could exist within Paleozoic carbonate rocks down the dip of the gentle southern limb of the Gardiner syncline (fig. A-4). Thermal waters in the northern half of the study area are carbonate-rich and are actively depositing travertine. Data collected on these travertine deposits, including their age and isotopic characteristics, indicate that thermal water from the Mammoth hydrothermal system probably discharged in the Gardiner area and near Rattlesnake Butte south of Bear Creek Springs prior to the last glacial recession about 12,000-15,000 years ago. More recent travertine accumulations and associated thermal springs at Bear Creek Springs and La Duke Hot Spring show different chemical and isotopic characteristics from thermal water and travertine at Mammoth Hot Springs, indicating that different flow paths and reservoir conditions may be involved with presentday thermal-water discharge in the KGRA.

The role of faults in enhancing or disrupting thermal-water flow northward from the Mammoth hydrothermal system to the KGRA is poorly understood. In the geologic map and the simplified structural map (fig. A-5) compiled in this study, a distinction is made between faults whose existence is evidenced by offsets of stratigraphic units or by geophysical data and faults whose 


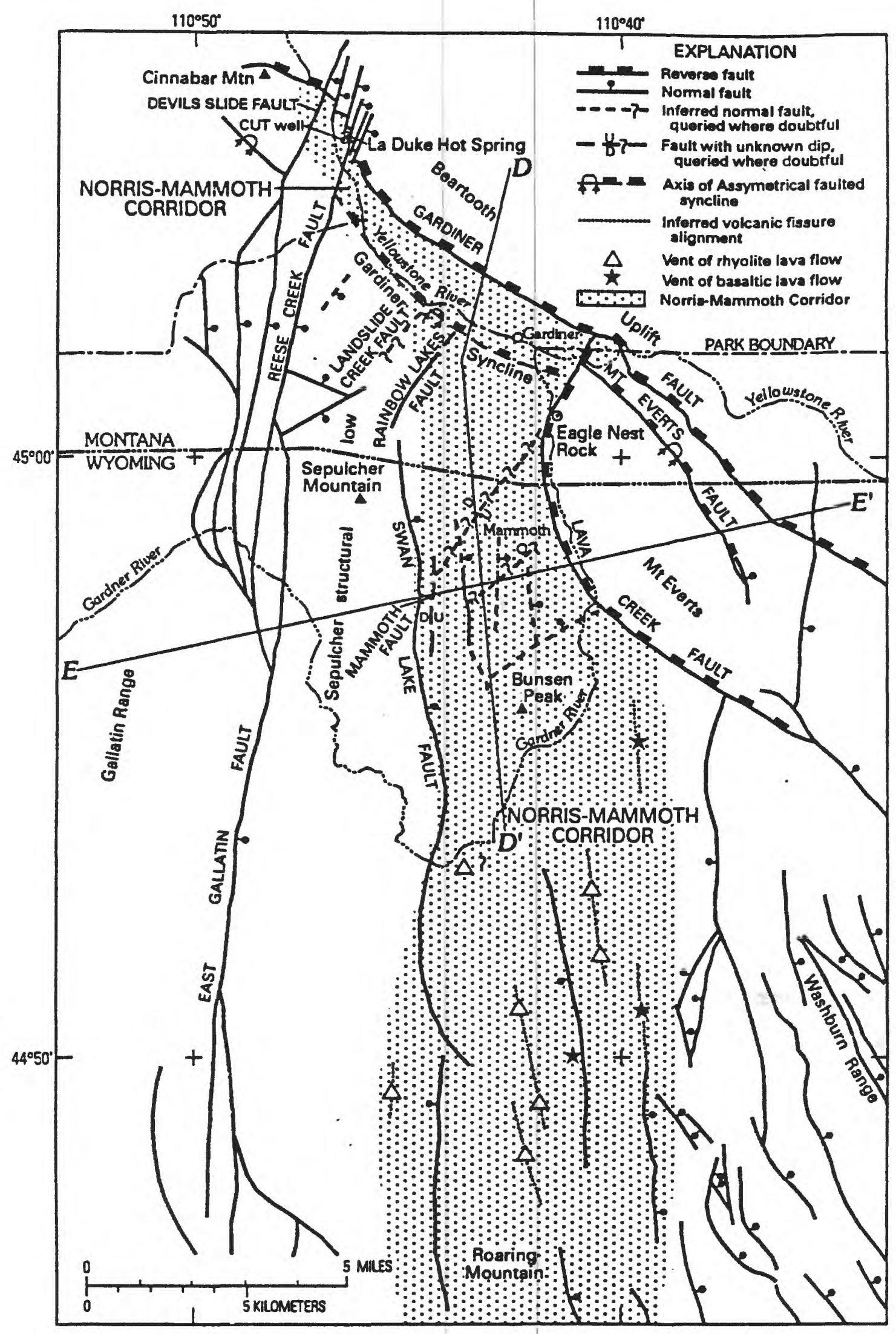

Figure A-5. Important structures in the Roaring Mountain-Mammoth-La Duke area. Shaded area -Norris-Mammoth corridor. Traces of geologic sections shown in figure A-4 are labeled EE' and DD'. 
existence is more speculative. In general, faults in the Mammoth Hot Springs area that might affect thermal-water flow cannot be confidently extended northward to the KGRA because of a lack of surface traces and subsurface structural information. There is evidence from electrical geophysical data of intense hydrothermal alteration along several faults near the north boundary of the Park that could signify thermal water flow at present or in the past. Soil-mercury anomalies and weak streambed-temperature anomalies, with associated faulting, were found at several locations near the Yellowstone River between the town of Gardiner and the confluence with Reese Creek (Hamilton and Chambers, this volume). The geothermal significance of these anomalies is unclear, but existing wells in this region $\left(27-40 \mathrm{~m}\right.$-deep) produce relatively dilute ground water at temperatures $\left(\sim 10^{\circ} \mathrm{C}\right)$ consistent with the observed streambed-temperature anomalies. Sulfate-flux measurements in the Yellowstone River did not detect input of Mammoth- or La Duke-type thermal water in this region.

Detailed geochemical investigations were done in 1989 and 1990 to evaluate whether components of thermal water from the Mammoth hydrothermal system could be detected in waters from La Duke Hot Spring and Bear Creek Springs, and to delineate possible hydraulic connections between the Mammoth hydrothermal system and thermal waters farther south along the NorrisMammoth corridor. The KGRA thermal waters are similar to thermal water from Mammoth Hot Springs in salinity and concentrations of major cations and anions. However, thermal waters from La Duke Hot Spring and the CUT geothermal well show significant differences from thermal waters at Mammoth Hot Springs in terms of (1) ratios of conservative constituents, (2) pressures of dissolved $\mathrm{CO}_{2}$, (3) stable water isotopes (deuterium and oxygen-18), and (4) isotopes of helium, strontium, boron, and lithium. These differences are consistent with the existence of separate hydrothermal systems involving reactions with different reservoir rocks under different thermodynamic conditions at each area. The stable-isotope data and relatively high chloride concentration $(170 \mathrm{mg} / \mathrm{L})$ show that thermal water from the Mammoth system has undergone hightemperature water/rock reactions at some point in its flow path, whereas La Duke (and Bear Creek) thermal water has not. The helium-isotope data show a substantial mantle-derived helium component in Mammoth thermal water but virtually none in La Duke thermal water.

The percentage of Mammoth-type water that could be in La Duke Hot Spring can be quantified using differences in conservative chemical characteristics such as helium concentration and helium-isotope ratio, chloride concentration, stable water isotopes, and isotopes of boron and lithium. There are limitations to the accuracy of these calculation due to uncertainties in the chemical and isotopic characteristics of the diluting end-member water, and in some cases, analytical accuracy and lack of undegassed thermal-water samples. Allowing for these uncertainties, the results of mixing-model calculations indicate that there could be at most a 5 percent Mammoth-type component, and most likely no Mammoth component, in La Duke Hot Spring water. In terms of the conservative characteristics used in these calculations, Mammoth-type thermal water should be the same as thermal water from deep reservoirs in the Mammoth hydrothermal system.

The hottest thermal waters from Bear Creek Springs have nearly the same concentrations of major constituents as the waters from Mammoth Hot Springs, but significant differences in other constituents such as chloride $(43 \mathrm{mg} / \mathrm{L}$ at Bear Creek Springs and $170 \mathrm{mg} / \mathrm{L}$ at Mammoth Hot Springs). Ratios of conservative constituents are similar at each area, but Bear Creek Spring water shows no oxygen-18 shift. This indicates that thermal water from both areas has been influenced by the same low-temperature processes and reservoir rock types, but that Mammoth water first undergoes high-temperature rock/water interactions. Strontium, boron, and lithium isotope values 
for Bear Creek thermal water are significantly different from those for Mammoth water, indicating that although the low-temperature rock/water interactions are similar, the rocks that are the source of these constituents are different. Alternatively, the chemical constituents in Bear Creek thermal water could be derived from the Mammoth system by mixing Mammoth-type water with three parts dilute cold water, reheating, and dissolving additional major ions (for example, $\mathrm{Ca}$ and $\mathrm{SO}_{4}$ ). Mixing-model calculations using stable water isotopes and isotopes of helium, boron, and lithium, are consistent with a $10 \pm 10$ percent Mammoth component in Bear Creek Springs, but do not prove that such a component exists. Elevated tritium concentrations in Bear Creek thermal water requires some near-surface mixing of thermal water with cold water of local origin.

The lack of a recognizable component of Mammoth-type thermal water in La Duke Hot Spring can be taken to mean that no hydraulic connection exists between these areas. There might be a small component of Mammoth-type water in Bear Creek Springs, but most of this thermal water must be derived from other sources. Lack of hydraulic connection implies either that there are no continuous flow paths (hydrogeologic connections) between these areas or that the existing distribution of hydraulic head effectively prevents or restricts thermal water flow from the Mammoth system to La Duke and Bear Creek. Although the altitude difference between hot springs at Mammoth and La Duke of about $450 \mathrm{~m}$ (higher at Mammoth) would tend to drive ground-water flow northward from Mammoth toward La Duke, information on the distribution of hydraulic head in permeable zones between these areas does not exist. The observation that very little, if any, Mammoth-type water reaches La Duke Hot Spring despite the large head difference available to drive thermal-water flow from Mammoth to La Duke, indicates the possibility of geologic barriers to such flow. Such barriers could take the form of fault-related stratigraphic discontinuities or Tertiary intrusives beneath the Sepulcher Mountain area. However, we cannot rule out the alternative possibility that the proximity of potential high-altitude recharge areas supplying water to La Duke Hot Spring and Bear Creek Spring causes higher heads in underlying thermal aquifers than in adjacent aquifers that might be transmitting thermal water northward from the Mammoth hydrothermal system. Thus, we conclude that hydraulic-head conditions, rather than geologic barriers, could be preventing thermal water from the Mammoth hydrothermal system from reaching La Duke Hot Spring.

If hydrogeologic connections exist between the Mammoth hydrothermal system and thermal areas in the Corwin Springs KGRA, geothermal development in the KGRA that resulted in large head declines in production reservoirs could conceivably alter the existing head distribution enough to establish hydraulic connections with the Mammoth system. In that case, decreases in hot-spring flow in the Mammoth area could occur. If, instead, separate hydrothermal systems supply hot springs at each area and there are no hydrogeologic connections between areas, then geothermal development in the KGRA could not affect Mammoth Hot Springs and associated thermal features. The available information does not allow us to determine with certainty which situation exists.

\section{Development Factors}

Geothermal development in the Corwin Springs KGRA could involve production of thermal water from wells, utilization of downhole heat exchangers in wells to extract heat but not fluid from reservoirs, or diversion of hot-spring discharge. Unmanipulated diversion of natural hot-spring discharge would pose no risk of adverse effects to thermal features in Yellowstone National Park. 
The same would be true for developments involving downhole heat exchangers and water from sources other than geothermal reservoirs to circulate through wells.

For geothermal development involving production of thermal water from wells, factors such as the location and rate of production influence the distribution of reservoir drawdown and the possibility of effects on the Park's thermal features. Fluid production that resulted in only relatively small, localized, drawdown in production reservoirs would pose no threat to thermal features at Mammoth Hot Springs, whether or not a hydraulic connection existed between the development area and Mammoth Hot Springs. Reservoir drawdown would be minimized if geothermal production were limited in the La Duke area to rates less than the total natural discharge of thermal water to the Yellowstone River and if wells produced water from the same reservoir that feeds the natural thermal-water discharge. We have determined from four sets of measurements that under present conditions this total natural discharge is $61 \pm 8.5 \mathrm{~L} / \mathrm{s}$, all of which enters the Yellowstone River upstream of Corwin Springs. Similar chemical compositions of water from La Duke Hot Spring and water from springs at river level indicate that these features are derived from the same thermal reservoir.

Fluid production from the existing CUT geothermal well has been shown to divert thermal water from La Duke Hot Spring to the well. Thus, sustained production of this well at rates near the flow of La Duke Hot Spring (5-9 L/s) would pose no risk of adverse effects on thermal features in Yellowstone National Park. It is most likely that sustained production from this well at rates near $25 \mathrm{~L} / \mathrm{s}$, which is near its capacity, would also be obtained mainly from diversion of thermal water from La Duke Hot Spring and other thermal springs and seeps that currently discharge into the Yellowstone River. Under this condition, reservoir drawdown would remain small and the risk of adverse effects on the Park's thermal features would also be avoided.

Additional geothermal wells drilled in the La Duke area into the same reservoir as the existing CUT geothermal well could also obtain most of their production from diversion of the natural thermal-water discharge, provided the combined production from all such wells was less than about $60 \mathrm{~L} / \mathrm{s}$. Determination that these conditions are met may be more difficult than for the existing CUT geothermal well if sustained production from this well had caused La Duke Hot Spring to stop flowing.

A corresponding production-rate limit of about $17 \mathrm{~L} / \mathrm{s}$ could prevent adverse effects on thermal features at Mammoth from geothermal development in the Bear Creek Springs area. This limit, however, is based on one set of measurements of sulfate flux in the Yellowstone River near Bear Creek and additional measurements are needed for confirmation. Geothermal-fluid production that captured this natural thermal-water discharge would pose no risk to Mammoth Hot Springs, but might constitute an adverse effect to the Park because this discharge occurs near or inside the Park boundary.

For the region in the Corwin Springs KGRA between Bear Creek Springs and La Duke Hot Spring, a production-rate limit cannot be specified at this time that would eliminate the risk of adverse effects to the Park's thermal features. There are no active thermal springs in this region, and sulfate-flux measurements in the Yellowstone River have not delineated significant inflow of thermal water to the river. Additional information from well drilling and testing is needed before a meaningful assessment of reservoir conditions and effects of potential geothermal development 
in this region can be made.

Geothermal development involving well production at rates that greatly exceed the natural thermal-water discharge in the development area could cause substantial reservoir drawdown both within and away from the production area. Under these conditions, detection of head changes in permeable zones beneath the Park would require a monitoring program with observation wells completed near the Park boundary in formations that are hydraulically connected with the production reservoir.

Additional information on the existing distribution of hydraulic head is required to estimate the degree of reservoir drawdown needed to establish a hydraulic connection with the Mammoth hydrothermal system. Should such a connection be established, the rate and amplitude of the spread of subsequent production-induced head changes would depend on the hydraulic properties of the connection, which could be determined from monitor wells and well flow tests. Relatively rapid (0.5-1.5 years) propagation of head changes could occur if properties similar to those determined from the 1986 flow test on the CUT geothermal well were applicable. The flow of hot springs on the Mammoth Terraces is likely to be sensitive to small changes in head in underlying reservoirs. Thus, a well monitoring system would be needed to provide early detection of the spread of head changes toward the Mammoth area. Data from an effective well monitoring system could be used to eliminate or significantly reduce the risk of adverse effects of large-scale development on the Park's thermal features, but completion of observation wells that are adequate for this purpose requires collection and interpretation of considerable subsurface information from drilling and subsequent well testing.

An alternative method of minimizing reservoir drawdown during fluid production is to inject some or all of the produced fluid back into the production reservoir. For this purpose, injection wells need to be located as close as possible to production wells without causing premature cooling of produced fluids. Selection of adequate spacing between production and injection wells requires knowledge of the hydraulic properties of the reservoir, in the case of the Corwin Springs KGRA, the location and properties of potential production reservoirs are largely unknown. Thus, considerable additional hydrogeologic data need to be collected from well drilling and testing before a production-injection scheme could be devised that would assure prevention of adverse effects to thermal features in Yellowstone National Park.

\section{Conclusions}

The principal conclusions of the U.S. Geological Survey study of the effects of potential geothermal development in the Corwin Springs KGRA on the thermal features of Yellowstone National Park are listed below.

1. The only areas of hot-spring discharge in the Corwin Springs KGRA are at or near La Duke Hot Spring and Bear Creek Springs. Travertine is actively being deposited by thermal waters at each area. Extensive travertine deposits north of the town of Gardiner, Montana, where there are no active thermal springs, were formed 19,000-23,000 and $50,000-60,000$ years ago. These older deposits are isotopically similar to travertine at Mammoth Hot Springs, indicating that they could have been derived from the same 
hydrothermal system that has been intermittently active in the Mammoth area for at least the past 400,000 years.

2. The available geologic and geophysical evidence indicates that hydrogeologic connections, or permeable pathways, could exist between thermal areas in the Corwin Springs KGRA and Mammoth Hot Springs, but does not prove their existence.

3. Thermal waters in the La Duke area, although generally similar in chemical composition to thermal waters at Mammoth Hot Springs, have some distinctly different chemical and isotopic characteristics from those in Mammoth-type thermal water. These differences indicate that there is little or no Mammoth-type thermal water in La Duke Hot Spring. This implies that the flow system supplying La Duke Hot Spring is separate from and is not hydraulically connected to the Mammoth hydrothermal system. This lack of connection could result from geologic barriers (impermeable rock or stratigraphic discontinuities) to flow from Mammoth to La Duke or from the existing distribution of hydraulic head beneath the La Duke area.

4. If the apparent lack of thermal-water flow between Mammoth and La Duke reflects hydraulic head conditions rather than geologic barriers, a hydraulic connection could conceivably be established between these areas if geothermal development caused substantial changes in hydraulic head within production reservoir(s).

5. Should a hydraulic connection be established between the La Duke area and Mammoth Hot Springs as a result of large-scale geothermal development, head changes could conceivably be induced beneath the Mammoth area that would cause decreases in spring flow at Mammoth Hot Springs.

6. Chemical and isotopic evidence is consistent with a minor component of Mammoth-type thermal water in Bear Creek Springs, indicating that there could be a hydraulic connection between these two areas. The major part of the thermal-water discharge in the Bear Creek area, however, appears to come from sources. other than the Mammoth hydrothermal system.

7. Geothermal development in the Bear Creek area that induced substantial reservoir drawdown could also affect Mammoth Hot Springs. The chances of adverse effects from such development could be greater than for development in the La Duke area because of the closer proximity of Bear Creek to Mammoth and the possibility that a hydraulic connection already exists. Similar effects could accompany geothermal development in other parts of the KGRA between the Bear Creek and La Duke areas if large reservoir drawdowns are induced. However, the degree of hydraulic connection between such areas and thermal features in the Park is unknown.

8. Restricting geothermal well production in the Corwin Springs KGRA to reservoirs that supply the natural thermal-water discharge near La Duke Hot Spring and Bear Creek Springs would allow capture of some or all of this discharge, and hence minimize reservoir drawdown. Production from the existing geothermal well drilled by the Church Universal and Triumphant at rates up to $25 \mathrm{~L} / \mathrm{s}$ most likely meets these criteria and 
therefore poses no discernible risk of adverse effects on the Park's thermal springs.

9. Additional geothermal wells could be produced in the La Duke area without risk to the Park's thermal features if the combined production rate from all such wells were less than the total natural rate of thermal-water outflow $(50-70 \mathrm{~L} / \mathrm{s})$ and each well produced from the same reservoir as the CUT geothermal well. A combination of well tests and chemical sampling, spring monitoring, sulfate-flux measurements, and possibly observation-well drilling is needed to show that such wells obtained most or all of their production from the capture of natural thermal-water discharge.

10. A decline in natural thermal-water discharge into the Yellowstone River is likely to accompany geothermal well production in the Bear Creek Springs area. Such discharge presently occurs within or immediately upstream from the Park boundary at rates near 17 L/s.

11. A decline in natural thermal-water discharge into the Yellowstone River is likely to accompany geothermal well production in the La Duke Hot Spring area. Such discharge presently occurs within a distance of about $1 \mathrm{~km}$ upstream and $1 \mathrm{~km}$ downstream from La Duke Hot Spring.

12. Surface diversion of the natural, unmanipulated flow of La Duke Hot Spring for direct heat applications on the Royal Teton Ranch would pose no threat to the thermal features in the Park. The flow of La Duke Hot Spring currently ranges from about 5 to $9 \mathrm{~L} / \mathrm{s}$.

13. Utilization of downhole heat exchangers in wells to extract heat but not fluid from geothermal reservoirs would also pose no threat to thermal features in Yellowstone National Park.

14. Injection of produced geothermal fluid back into production reservoirs would lessen reservoir drawdown and reduce the possibility of adverse effects on thermal features inside the Park. Locating and completing injection wells to accomplish this purpose will require collection and interpretation of geologic and hydrologic data that currently do not exist for the KGRA.

The results of this study point to scientifically valid reasons for concern regarding adverse effects of large-scale geothermal development in the Corwin Springs KGRA on thermal features at and near Mammoth Hot Springs in Yellowstone National Park. Such development could cause reservoir head changes large enough to establish or enhance a positive head gradient for northward flow within permeable zones that might exist between the KGRA and Mammoth Hot Springs. Because of the absence of subsurface hydrogeologic data in this area, we do not know for certain that such zones do not exist, and instead can offer several lines of indirect evidence to indicate that they could be present. Given this situation, there exist several technical options for development that would minimize or eliminate adverse effects on the Park's thermal features. The level of risk that geothermal development poses for adverse effects on thermal features depends on where development occurs, which development option is followed, and which of the Park's thermal features is considered. 


\section{References Cited}

Fournier, R.O., 1989, Geochemistry and dynamics of the Yellowstone National Park hydrothermal system: Annual Review of Earth and Planetary Science, v. 17, p. 13-53.

White, D.E., Hutchinson, R.A., and Keith, T.E.C., 1988, The geology and remarkable thermal activity of Norris Geyser Basin, Yellowstone National Park, Wyoming: U.S. Geological Survey Professional Paper 1456, 84 p. 


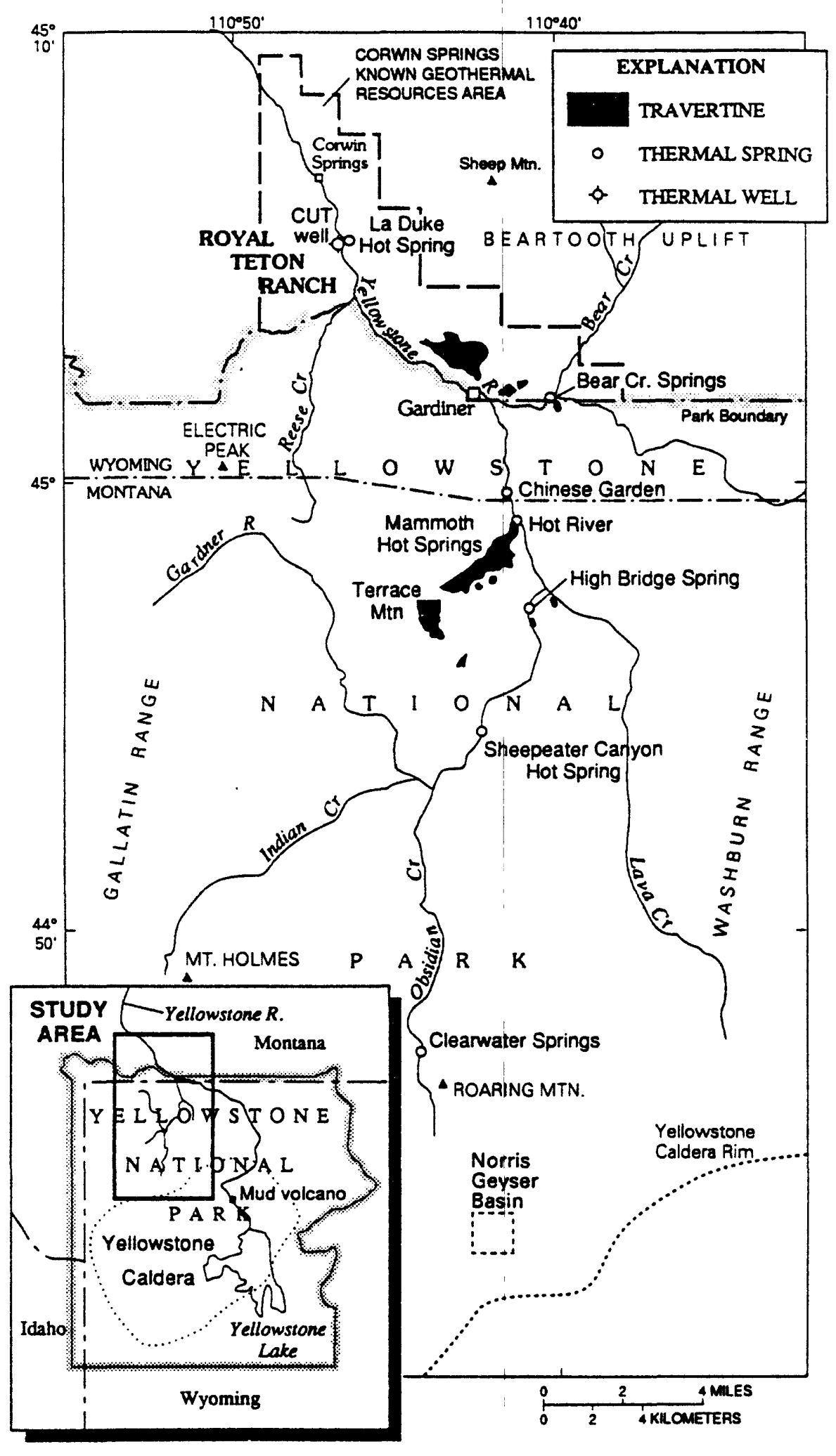

Figure B-1. Corwin Springs Known Geothermal Resources Area - Yellowstone National Park study area showing areas of hot-spring discharge noted in text and the geothermal well drilled by the Church Universal and Triumphant (CUT well) on the Royal Teton Ranch. 
Springs KGRA since that time. Public and governmental concerns over the potential effects on thermal features within Yellowstone National Park from long-term production from this well and other such wells that might be drilled within the Corwin Springs KGRA led to suspension of geothermal leasing activities on public lands surrounding the park in 1988 (Public Law 100-443).

Mammoth Hot Springs and Hot River are the principal thermal features in Yellowstone Park that are nearest to La Duke Hot Spring, although thermal seeps have been detected in the area referred to as Chinese Garden located about $1 \mathrm{~km}$ north of Hot River. These areas are about $14 \mathrm{~km}$ southeast of La Duke. Thermal waters in the Mammoth area and in the adjacent KGRA contain relatively high concentrations of bicarbonate ions and are actively depositing travertine (calcium carbonate). Extensive travertine deposits that occur just north of the town of Gardiner, between La Duke and Bear Creek, indicate voluminous discharge of carbonate-rich thermal waters in the geologic past. The similarities in thermal-fluid chemistry at Mammoth, Bear Creek, and La Duke and the occurrence of numerous geologic features (faults and sedimentary formations) that could provide flow paths at depth between each area provide some reasons for concern regarding the potential effects of future geothermal development in the Corwin Springs KGRA on thermal features within the Park.

For the purposes of this report, the study area encompasses a rectangular region from the Norris Geyser Basin on the south to the northern end of the Corwin Springs KGRA on the north (fig. B-1). The Gallatin and Washburn Ranges and Beartooth uplift lie on the western, eastern, and northeastern sides of the study area, respectively. Several ranges comprise the Beartooth uplift. Land-surface elevations in the study area decrease from about $2,400 \mathrm{~m}(8,000 \mathrm{feet})$ at the south to about $1,700 \mathrm{~m}$ (5,600 feet) at the north end of the study area, although elevations exceeding 2,900 $\mathrm{m}(9,600$ feet) are attained in the Gallatin Range and the Beartooth uplift (fig. B-2). The study area was extended as far south as the Norris Geyser Basin to evaluate the possibility of a thermal-water flow between Mammoth and hot spring areas near the edge of the Yellowstone caldera, as suggested in previous studies (White and others, 1988; Fournier, 1989). Several unpublished reports describe possible sources of water for the hot springs in the Corwin Springs KGRA and possible hydrologic connections with geothermal reservoirs inside the Park (Struhsacker, 1976; Sonderegger, 1987; and Hydrometrics, 1986).

\section{Purpose and Scope}

Our study addressed three principal issues: (1) the sources of thermal water for the hot springs at Mammoth, La Duke, and Bear Creek, (2) the degree of hydraulic connection between these areas, and (3) the effects of geothermal development in the KGRA on thermal features in the Mammoth area. During 1988-90, geologic, geochemical, and geophysical investigations were done to provide data useful in addressing these issues. An additional objective was to collect baseline data on the variability in discharge characteristics of thermal springs in the study area. Collaborative investigations were done by the National Park Service, Argonne National Laboratory, and Los Alamos National Laboratory. Subsequent chapters of this report present detailed discussions of the findings of these investigations. 


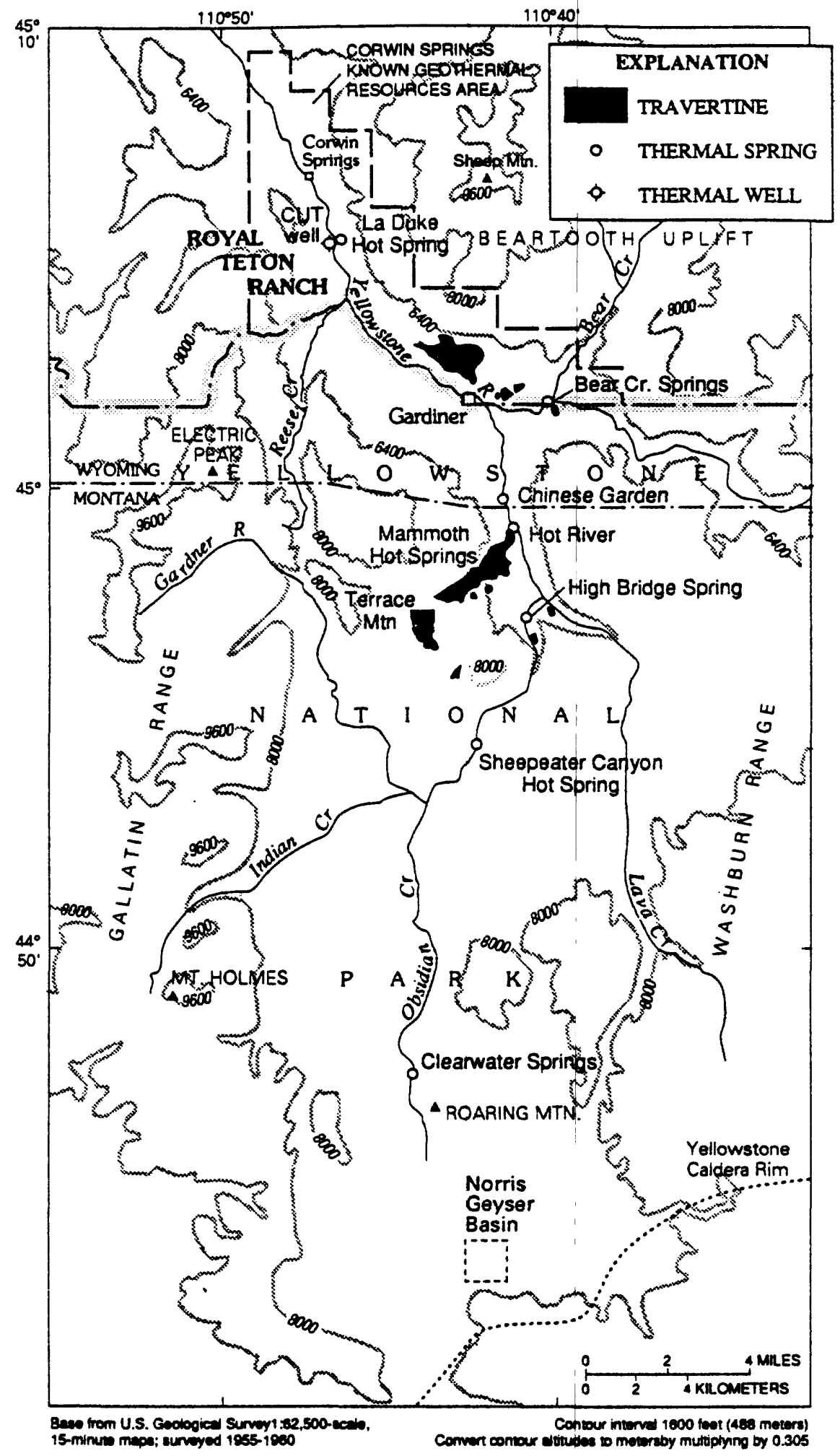

Figure B-2. Corwin Springs Known Geothermal Resources Area - Yellowstone National Park study area in and adjacent to Yellowstone National Park, showing land-surface altitude and principal areas of hot-spring discharge. 
The following persons were responsible for conducting different aspects of the study:

Technical coordinator:

Geologic investigations:

Geophysical investigations:

Geochemical investigations:

Hydrologic investigations:

Soil mercury and streambedtemperature investigations:
M.L. Sorey (U.S. Geological Survey)

K.L. Pierce (U.S. Geological Survey)

D.B. Hoover (U.S. Geological Survey)

W.D. Stanley (U.S. Geological Survey)

Y.K. Kharaka (U.S. Geological Survey)

R.H. Mariner (U.S. Geological Survey)

N.C. Sturchio (Argonne National Lab)

M.L. Sorey (U.S. Geological Survey)

D.R. Janecky (Los Alamos National Laboratory)

W.L. Hamilton (National Park Service)

\section{Terminology}

Definitions of many of the scientific terms used in this report are given in "Conversion Factors, Vertical Datum, and Abbreviations" on pages VIII-X. Of particular significance are the terms "thermal spring", "hot spring", and "warm spring". The definition of Meinzer (1923) that thermal springs are those springs whose water has a temperature appreciably above the mean annual temperature of the atmosphere in the vicinity of the spring was used for this study. Following the U.S. Geological Survey assessment of low-temperature geothermal resources (Reed, 1982), $10^{\circ} \mathrm{C}$ above ambient was used as the criterion for "appreciably." The term "thermal water" is more loosely considered in this report to apply to water derived from a hydrothermal system involving elevated fluid and rock temperatures and concentrations of dissolved chemicals substantially in excess of typical shallow ground water. "Hot spring" is defined as a thermal spring warmer than body temperature $\left(37^{\circ} \mathrm{C}\right)$; "warm spring" is a thermal spring cooler than body temperature. In regard to the Mammoth hydrothermal system, a distinction between thermal water derived from the Mammoth hydrothermal system and Mammoth-type thermal water was made, the later being any thermal water with chemical characteristics similar to those found in water sampled at Mammoth Hot Springs. A final introductory note is that the spelling of the town of Gardiner, Montana, is different from the spelling of the Gardner River.

\section{Acknowledgments}

The editor would like to thank each author for their contributions to the investigations described in this report. This report represents a team effort by numerous individuals with expertise in different disciplines and specialties. Answers to the questions addressed in this study were difficult to develop and differences of opinion and emphasis between authors required considerable discussion and debate to reach consensus. This process was facilitated by technical reviews of the report provided by Manuel Nathenson, Christopher D. Farrar, L.J. Patrick Muffler, Robert O. Fournier, Irving Friedman, and Robert L. Christiansen of the U.S. Geological Survey, and by Fraser Goff of Los Alamos National Laboratory. In particular, the editor expresses his thanks to Manuel Nathenson and Christopher D. Farrar for their efforts to improve this report. 


\section{References Cited}

Francis, E.L., 1987, Testimony given July 14, 1987 by Edward L. Francis of the Church Universal and Triumphant to Senate Subcommittee on Mineral Resource Development and Production, $10 \mathrm{p}$.

Fournier, R.O., 1989, Geochemistry and dynamics of the Yellowstone National Park hydrothermal system: Annual Review of Earth and Planetary Science, v. 17, p. 13-53.

Goodwin, L.H., Haigler, R.L., Rioux, R.L., White, D.E., Muffler, L.J.P., and Wayland, R.G., 1971, Classification of public lands valuable for geothermal steam and associated geothermal resources: U.S. Geological Survey Circular 647, 9 p.

Hydrometrics, 1986, Aquifer testing and evaluation of a geothermal well at Royal Teton Ranch near Corwin Springs, Montana: Report prepared for Edward L. Francis, Royal Teton Ranch by Hydrometrics, 2727 Airport Rd, Helena, Montana 59021, 37 p.

Meinzer, O.E., 1923, Outline of ground-water hydrology: U.S. Geological Survey Water Supply Paper 494, $71 \mathrm{p}$.

Reed, M.J., ed., 1983, Assessment of low-temperature geothermal resources of the Unites States 1982: U.S. Geological Survey Circular 892, 73 p.

Sonderegger, J.L., 1987, Potential effects of production from a geothermal well located near La Duke Hot Spring: Montana Bureau of Mines unpublished report to Montana State Department of Health and Environmental Sciences and Department of Natural Resources and Conservation, $12 \mathrm{p}$.

Struhsacker, E.M., 1976, Geothermal systems of the Corwin Springs-Gardiner area, Montana: Possible structural and lithologic controls: M.S. thesis, Montana State University, Bozeman, Montana, $93 \mathrm{p}$.

White, D.E., Hutchinson, R.A., and Keith, T.E.C., 1988, The geology and remarkable thermal activity of Norris Geyser Basin, Yellowstone National Park, Wyoming: U.S. Geological Survey Professional Paper 1456, 84 p. 


\title{
CHAPTER C
}

\section{GEOLOGIC SETTING OF THE CORWIN SPRINGS KNOWN GEOTHERMAL RESOURCES AREA-MAMMOTH HOT SPRINGS AREA IN AND ADJACENT TO YELLOWSTONE NATIONAL PARK}

\author{
By Kenneth L. Pierce, U.S. Geological Survey \\ Kenneth D. Adams, Montana State University \\ and Neil C. Sturchio, Argonne National Laboratory
}

\section{Contents}

Introduction. C-1

Bedrock Geology.

Structures That Could Affect Geothermal-Fluid Circulation

Gardiner Reverse Fault and Associated Syncline

Lava Creek Reverse Fault

East Gallatin-Reese Creek Normal Fault System. C-18

Norris-Mammoth Corridor C-18

Structures in the Mammoth Area

Sepulcher Structural Low

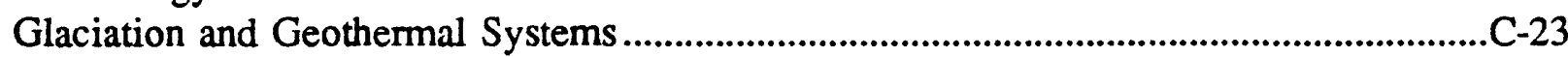

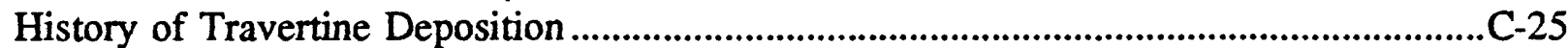

Hydrothermal Systems and Their Possible Interconnections .....................................................28

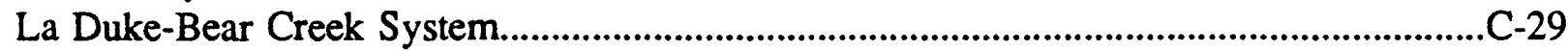

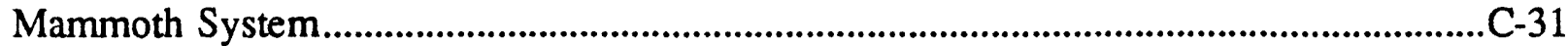

Travertine and Springs South of Mammoth ...................................................................

Hydrogeologic Connections Between Mammoth and La Duke .............................................32

Hydrogeologic Connections Between Mammoth and the Gardiner Travertine Bench.......C-33

Hydrogeologic Connections Between Mammoth and Bear Creek .....................................C-34

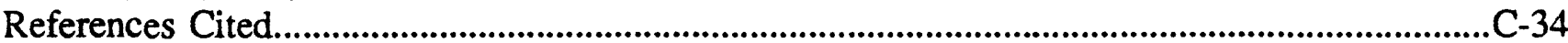

\section{Introduction}

Flanking the northern margin of Yellowstone National Park is the Corwin Springs Known Geothermal Resources Area (KGRA), which includes hot springs at La Duke and Bear Creek and the travertine deposits above Gardiner (fig. B-1). A north-south alignment of geothermal features extends from the Yellowstone caldera northward through Mammoth Hot Springs to the Corwin Springs KGRA. This section of the report describes the apparent geologic controls for thermal features in the northern part of this region, the geologic history of thermal activity, and some 
possible hydrogeologic connections between thermal springs in the KGRA and Mammoth Hot Springs.

Thermal features and their possible hydrogeologic connections are controlled by the subsurface geology, particularly the distribution of permeability related to either stratigraphic units or fault zones. Travertine deposits and active springs indicate a complex history of thermal activity interspersed with times of glaciation. In addition, the landscape has evolved due to valley deepening through time. During the last glaciation, glacial scour eroded a basin well below the present level of the Yellowstone River. The thermal waters encountered in bedrock in the CUT geothermal well are blanketed by about $130 \mathrm{~m}$ of relatively impermeable lake-sediment deposited in this scour basin.

\section{Bedrock Geology}

Although the bedrock geology of the Mammoth-La Duke area has been mapped and described in recent reports, no sufficiently detailed compilation covers the entire area. This is largely because three important boundaries occur between Mammoth Hot Springs and La Duke Hot Spring: the northern boundary of Yellowstone National Park, the state boundaries between Wyoming and Montana, as well as the common boundary of four $15^{\prime}$ quadrangles. For this reason a new compilation of the geology of the study area has been prepared for this report.

Figure C-1 shows the distribution of generalized geologic units and structures of the study area. The geologic map is based on a more detailed compilation and local field observations at a scale of 1:62,500 from the following sources: the pre-Tertiary geology of northern Yellowstone National Park at 1:62,500 by Ruppel (1972); an unpublished map of the Mammoth quadrangle at 1:62,500 (written commun., 1989) by R.L. Christiansen (U.S. Geological Survey), H.J. Prostka, E.T. Ruppel (Montana Bureau of Mines and Geology), and H.W. Smedes; the southwest quarter of the Gardiner quadrangle at 1:24,000 by Fraser and others (1969); the geology north of Yellowstone National Park in the La Duke area at 1:62,500 by Struhsacker (1976); the bedrock geology of Yellowstone National Park at 1:125,000 by the U.S. Geological Survey (1972); and a small-scale map of the Gardiner reverse fault area by Wilson (1934). Five geologic sections were developed through the northern part of the study area at 1:62,500, on the basis of our geologic map compilation and field relations observed during our study, and on published sections by Ruppel (1972), Fraser and others (1969), and Wilson (1934).

Figure $\mathrm{C}-2$ shows simplified versions of the geologic sections. Subsurface control is provided by projections of stratigraphic units in outcrops and other field relations, and by geologic sections by Ruppel (1972), Fraser and others (1969), and Wilson (1934). With increasing depth, particularly below $1-2 \mathrm{~km}$, the geologic sections become increasingly uncertain and therefore should be regarded as only diagrammatic. In an area of complex structure like this, such uncertainty is normal for geologic sections extending to depths of several kilometers but lacking subsurface geologic control 
from deep drilling or seismic profiles. Also, the dip of faults and their changes with depth are not known and intrusive bodies (Ti) may be present at depth and not yet recognized. For the Sepulcher structural low (Sections $\mathrm{CC}^{\prime}$ and $\mathrm{EE}^{\prime}$ ), surface geology provides very poor control for the vertical position of pre-Cenozoic stratigraphic units, as discussed below.

Figure $\mathrm{C}-3$ shows the pre-Cenozoic stratigraphy of the area. The carbonate units and probably to a lesser extent the sandstone units are aquifers, whereas the shales are confining units. The Mission Canyon Limestone (upper part of the Madison Group) forms an important aquifer in the Rocky Mountains and Great Plains due to solution porosity, especially near its top (Downey, 1984; Struhsacker, 1976). Solution caverns in the Mission Canyon Limestone and a karst topography beneath the overlying Amsden Formation are also noted by Ruppel (1972) from exposures in the Gallatin Range.

Cenozoic stratigraphic units are not shown in the columnar section (fig. C-3) because they are of minor importance to geothermal circulation and have complex inset stratigraphic relations not amenable to diagraming in columnar sections. Volcanic rocks of the Eocene Absaroka Volcanic Supergroup reach a thickness of about $1 \mathrm{~km}$ on Sepulcher Mountain. Quaternary volcanic rocks of ash-flow tuff, rhyolite flows, and basalt flows occur at and near the surface, and in the northern part of the area form an inset sequence related to valley deepening (fig. C-1). Glacial and other surficial deposits thinly mantle the bedrock over much of the area and are shown on Pierce (1973a, 1973b, and 1979).

\section{Structures That Could Affect Geothermal-Fluid Circulation}

\section{Gardiner Reverse Fault and Associated Syncline}

The Gardiner reverse fault strikes northwest and forms the southwest margin of the Beartooth uplift (fig. C-4). The Beartooth uplift (Brown, 1961) is a large block exposing Precambrian basement and extends from near Gardiner north to near Livingston, Montana, and east to Red Lodge, Montana. On the Gardiner reverse fault, Precambrian rocks were moved southwest and upward over Upper Cretaceous rocks, producing an asymmetrical syncline in the footwall block (Wilson, 1934; Fraser and others, 1969; Ruppel, 1972; Struhsacker, 1976). Stratigraphic offset on this compressional fault exceeds $3 \mathrm{~km}$ and occurred in Laramide time (Fraser and others, 1969) about 50 and 75 million years ago (Ma). On the footwall block, beds in the syncline are locally overturned, accompanied by much subsidiary shearing and thrusting. Where the synclinal axis is exposed on the north slope of Mt. Everts, the fold axis is occupied by the Everts reverse fault (fig. C-4). The Gardiner reverse fault does not offset Eocene Absaroka volcanic rocks to the northwest or southeast of the map area, but strongly folds Upper Cretaceous rocks, indicating Laramide activity (Wilson, 1934, Struhsacker, 1976; Foose and others, 1961). 


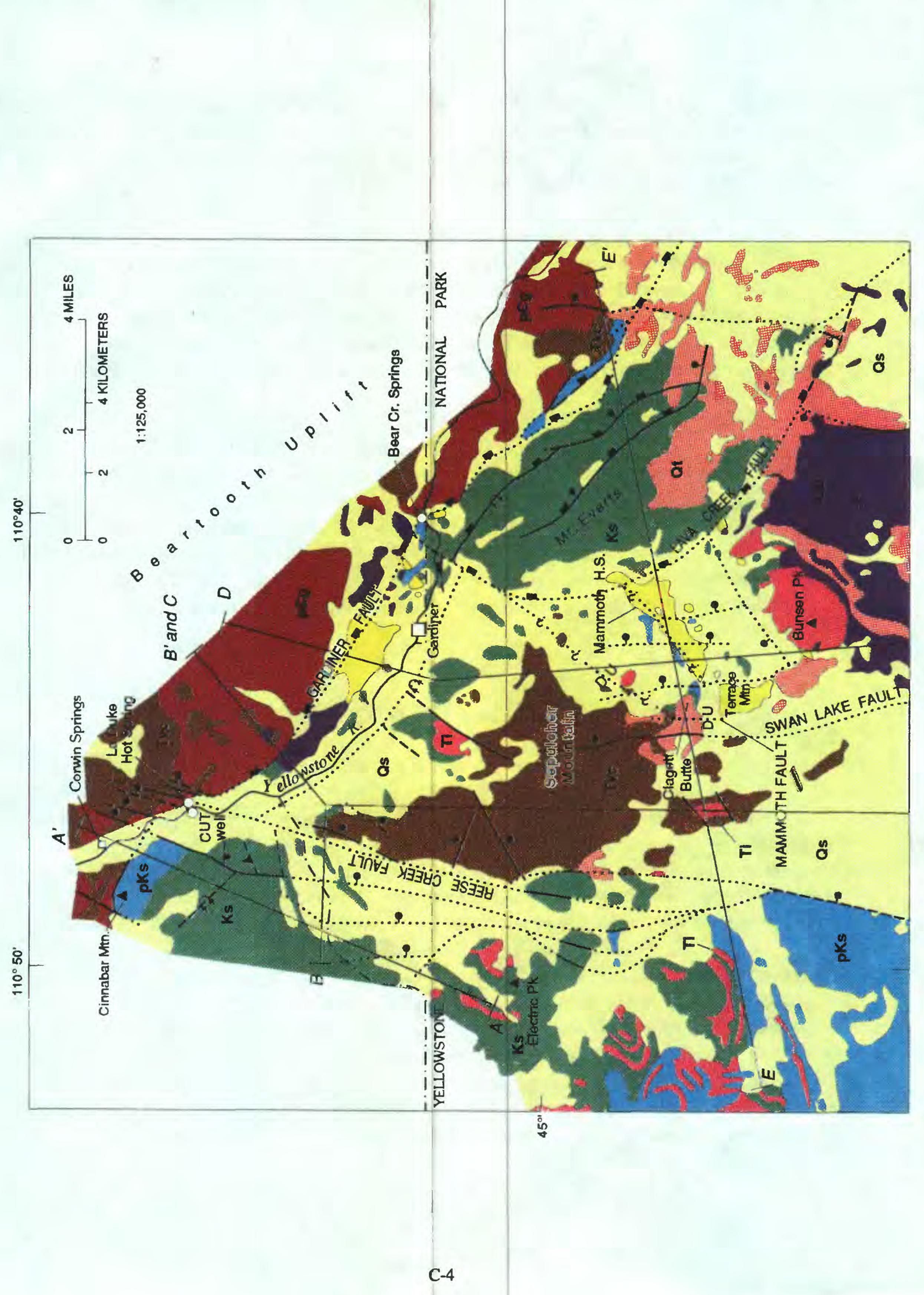




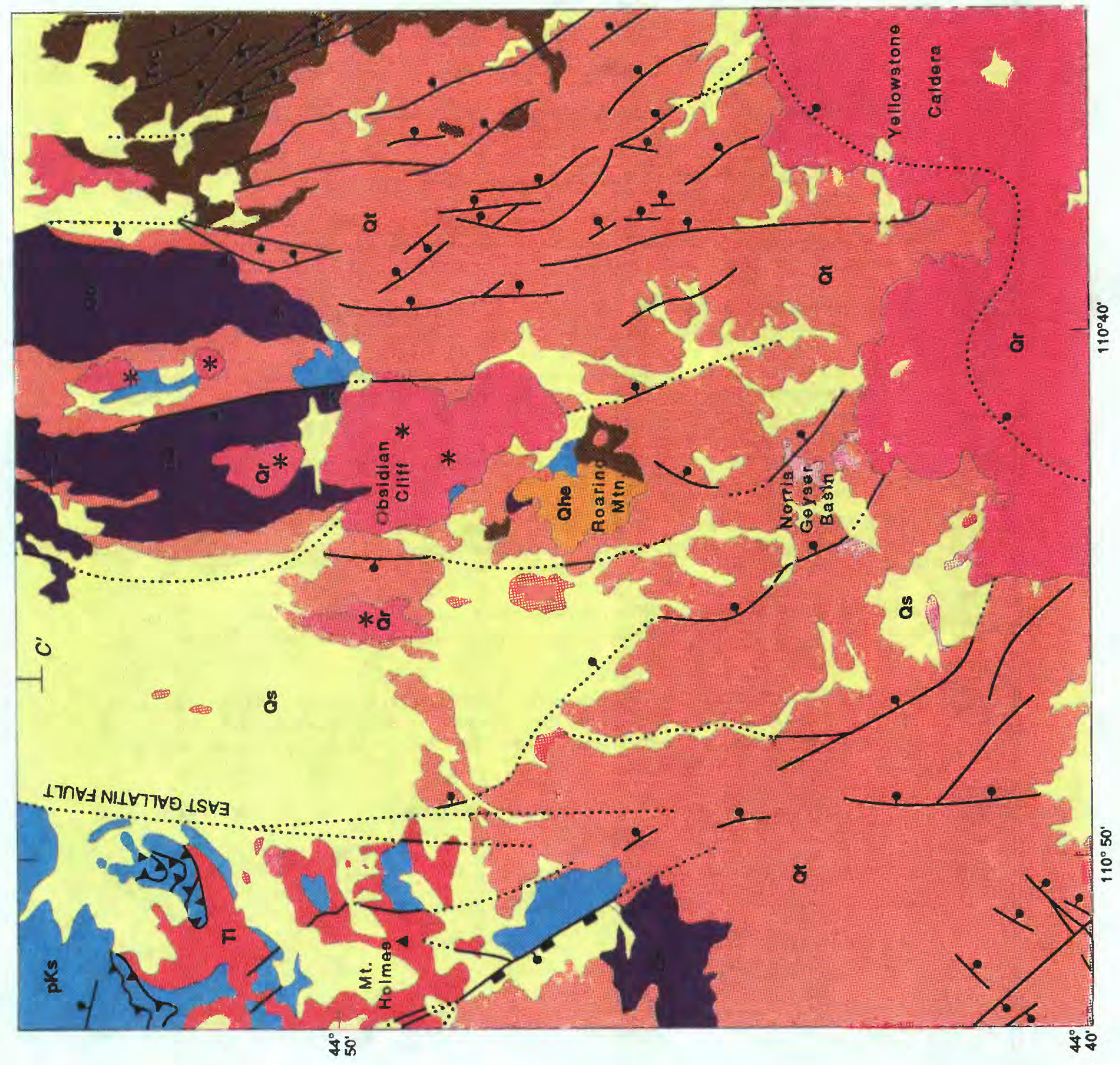


Q9

Qhe HYDROTHERMAL-EXPLOSION DEPOSITS -- Hydrothermal-explosion deposits from the Roaning Mountain explosion crater (U.S. Geological Survey, 1972).

Qtr TRAVERTINE - Calcium carbonate deposited by present and former hot springs. Includes travertine of pre-and post-Pinedale age $(0-400 \mathrm{ka})$.

Cs1 SINTER - Silica deposited by present and former hot springs. Includes noncarbonate (non-travertine) hot-spring deposits (Qt) of U.S. Geological Survey (1972).

BASALT -- Basait flows. Includes Osprey Basalt (Qo), Swan Lake Flat Basalt (Qsl), Madison River Basalt (Qmr), Undine Falls Basalt (Quf), and Junction Butte Basalt (Qjb) of U.S. Geological Survey (1972).

Cr RHYOLITE - Rhyolite flows and domes; myolite-basalı mixed lavas. Includes Gibbon river flow (Qpci), Solfatara Plateau flow (Qpcf), Roaring Mountain Member (Qpr) and Obsidian Creek Member (Qpo and Qpom) of Plateau Rhyolite of U.S. Geological Survey (1972).

at

TUFF -- Welded ash flows. Includes Lava Creek Tuff (Qyl) and Huckleberry Ridge Tuff (Qyh) of Yellowstone Group of U.S. Geological Survey (1972).

TI INTRUSIVE ROCKS -- Includes rhyodacite, quartz latite, quarz monzonite, granodiorite ( $T \mathrm{i}$ ), dacite (Tid) and intrusive rocks probably related to the Absaroka Volcanic Supergroup. Only larger bodies are shown from U.S. Geological Survey (1972).

VOLCANICLASTIC AND VOLCANIC ROCKS - Includes Sepulcher Formation (Ts) and other rocks of the dominantly andesitic Washbum Group of Absaroka Volcanic Supergroup of Eocene age (U.S. Geological Survey, 1972).

SANDSTONE AND SHALE OF CRETACEOUS AGE -- Includes Upper Cretaceous Landslide Creek Formation, Everts Formation, Eagle Sandstone, Telegraph Creek Formation. Cody Shale, and Frontier Sandstone Lower Cretaceous Mowry Shale, Thermopolis Shale, and Kootenai Formation; of U.S. Geological Survey (1972) See figure C-3 for lithologic column.

PRE-CRETACEOUS SEDIMENTARY ROCKS -- Limestone, sandstone, shale, siltstone, mudstone, and dolomite ranging in age from Jurassic to Cambrian.

GNEISS AND SCHIST - Undifferentiated metamorphic rocks of Precambrian age . 
Contact

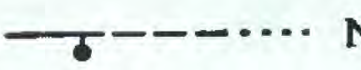

Normal fault - Dashed where inferred; dotted where concealed; queried where uncertain. Bar and ball on downthrown side

- -... Reverse fault - Dashed where inferred; dotted where concealed

- Reverse fault along which later normal faulting took place -- Dashed where inferred; dotted where concealed. Block teeth on overriding block. Bar and ball on downthrown side

T- $\boldsymbol{\nabla}-\boldsymbol{v}$. Thrust fault -- Dashed where inferred; dotted where concealed. Sawteeth on overniding plate

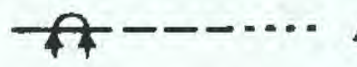

Axis of asymmetrical, overturned syncline -- Dashed where inferred; dotted where concealed

4ि Axis of asymmetrical, overtumed syncline with known or inferred reverse fault

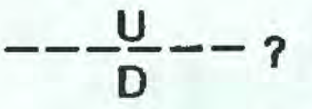

Fault of unknown dip -- Queried where doubtful. Sense of displacement indicated by $\mathbf{U}$ (up) and $\mathbf{D}$ (down)

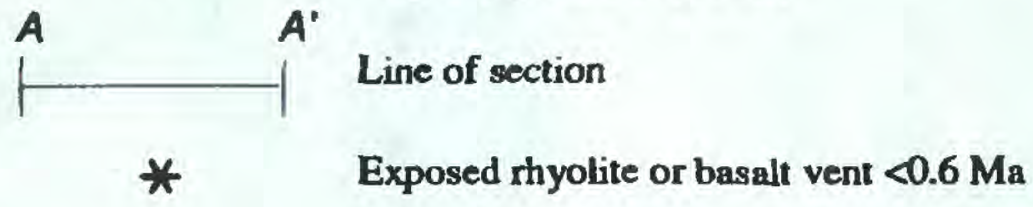

CORRELATION OF MAP UNITS
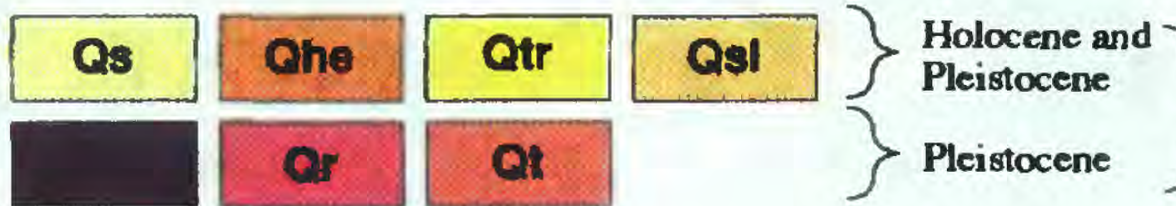

QUATERNARY
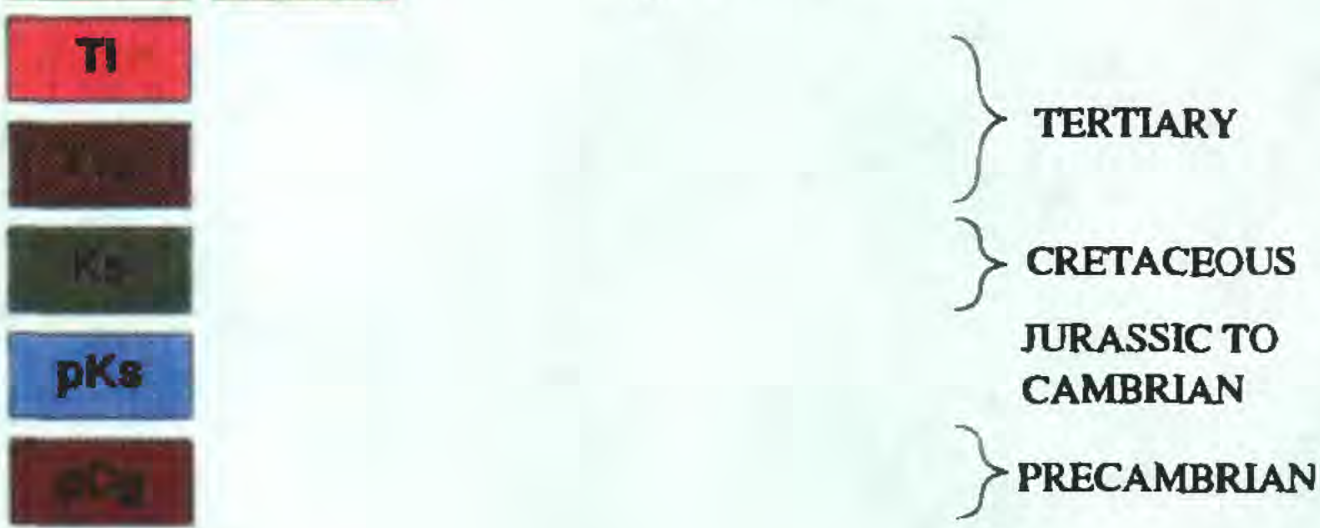

Compiled by F.H. Olmsted from U.S. Geological Survey (1972) and an unpublished map of the Mammoth quadrangle (written commun., 1989) by R.L. Christiansen, H.J. Prostka, E.T. Ruppel, and H.W. Smedes for southern part of area; and from a 1:62,500 compilation by K.D. Adams for the northem part, based on U.S. Geological Survey (1972); Ruppel (1972), Fraser and others (1969); Struhsacker (1976); Wilson (1934) for the northem part of the area.

Figure C-1. Geology of the Norris-Mammoth-La Duke area in and adjacent to Yellowstone National Park. 

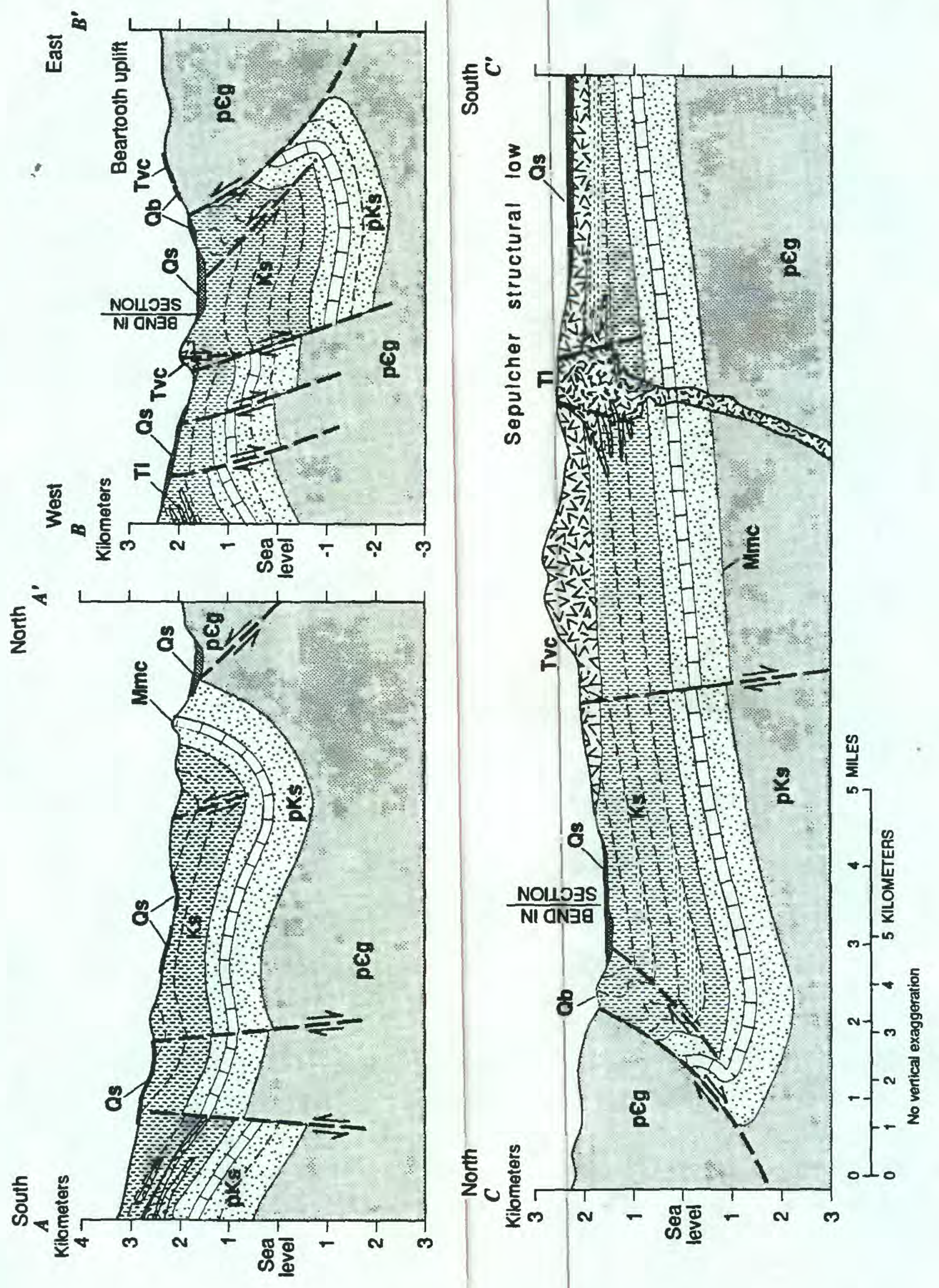

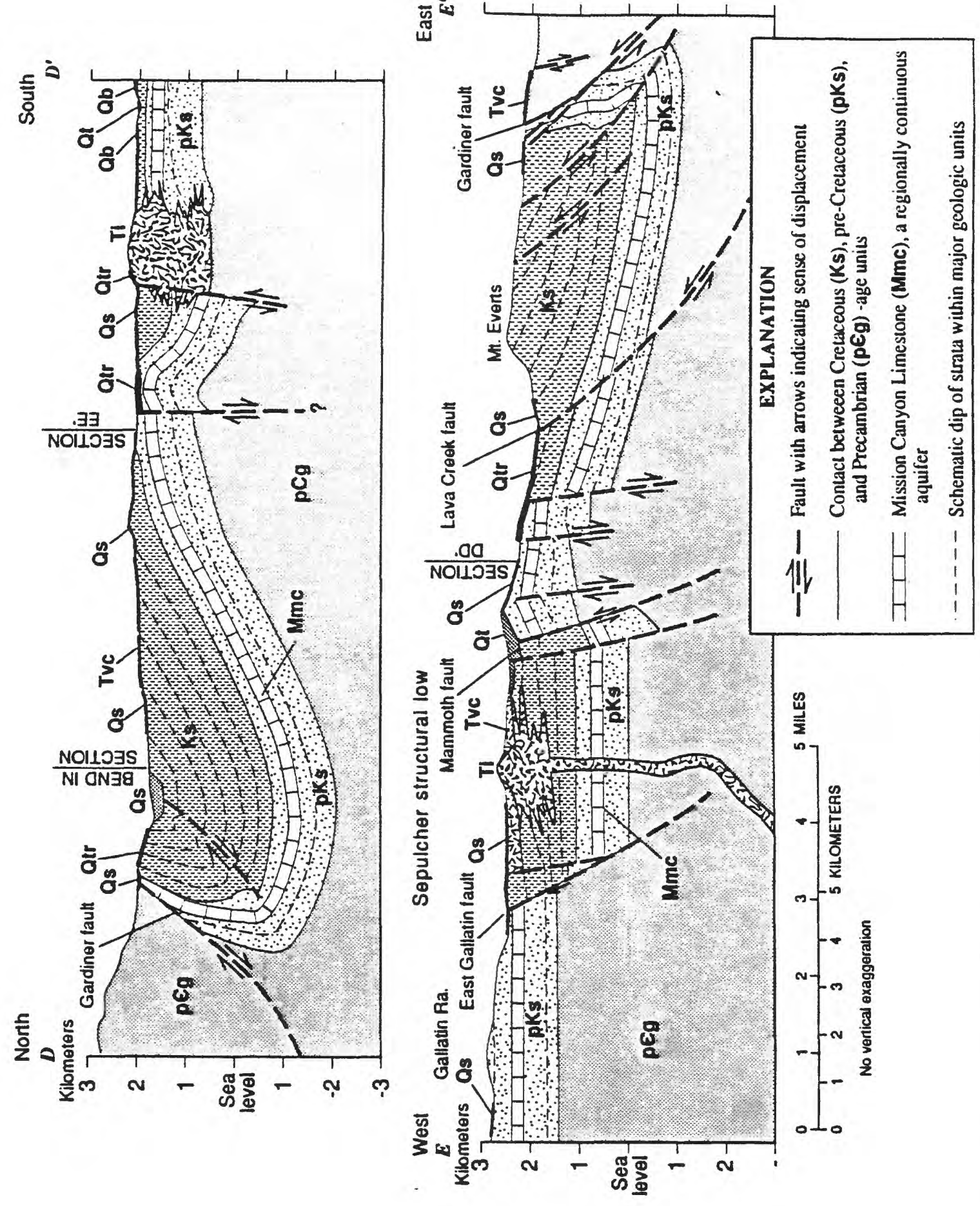


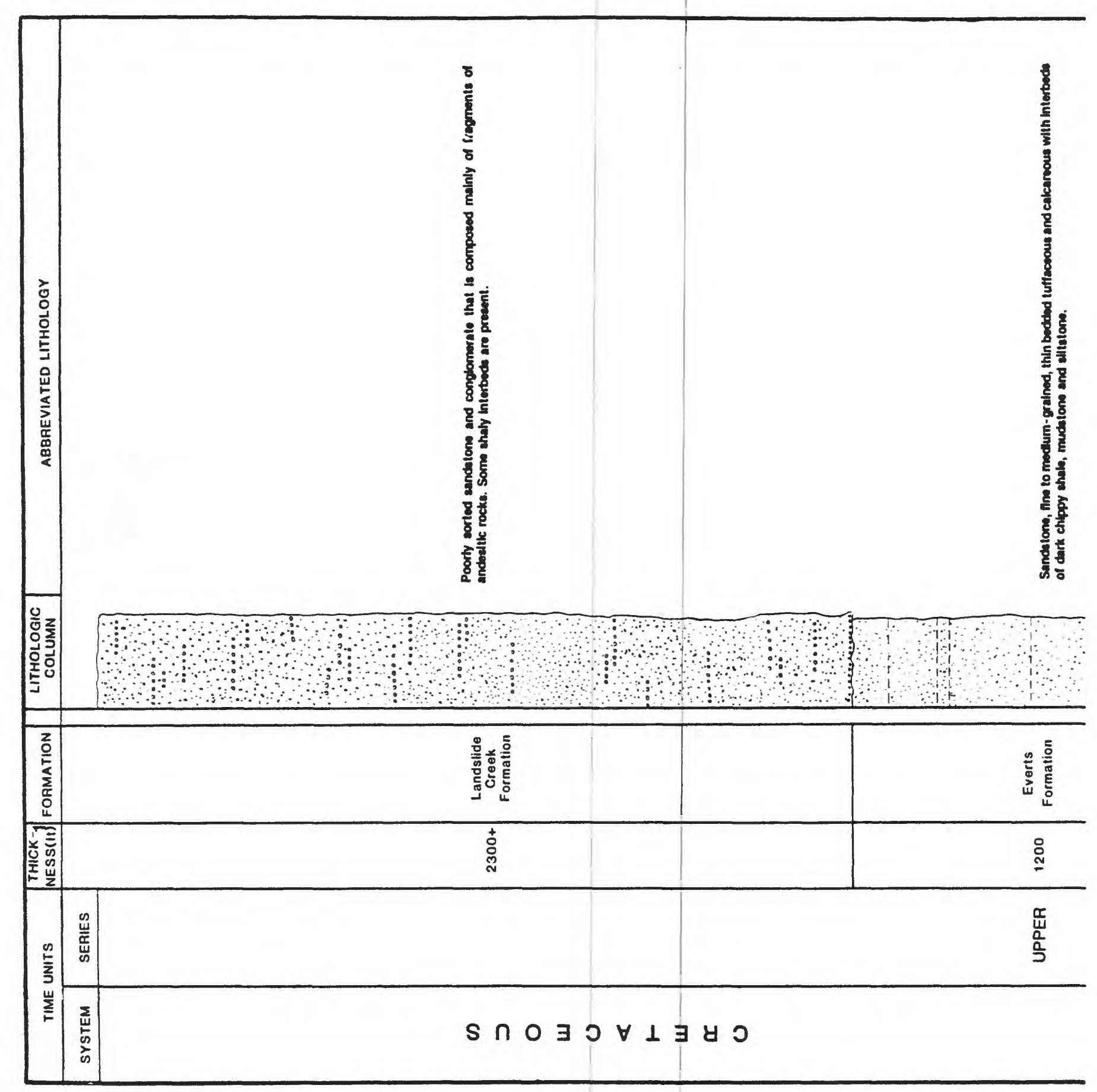




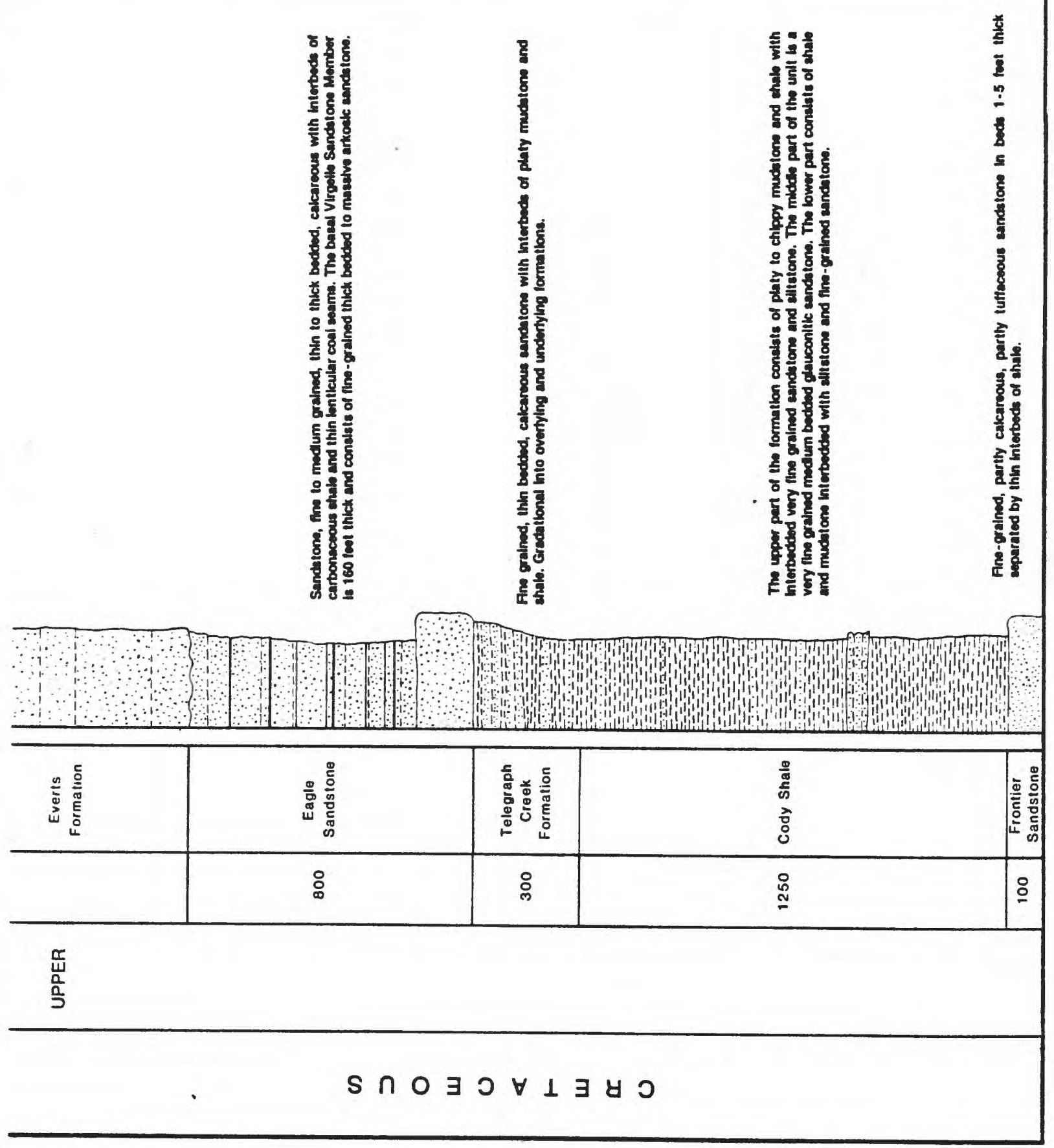




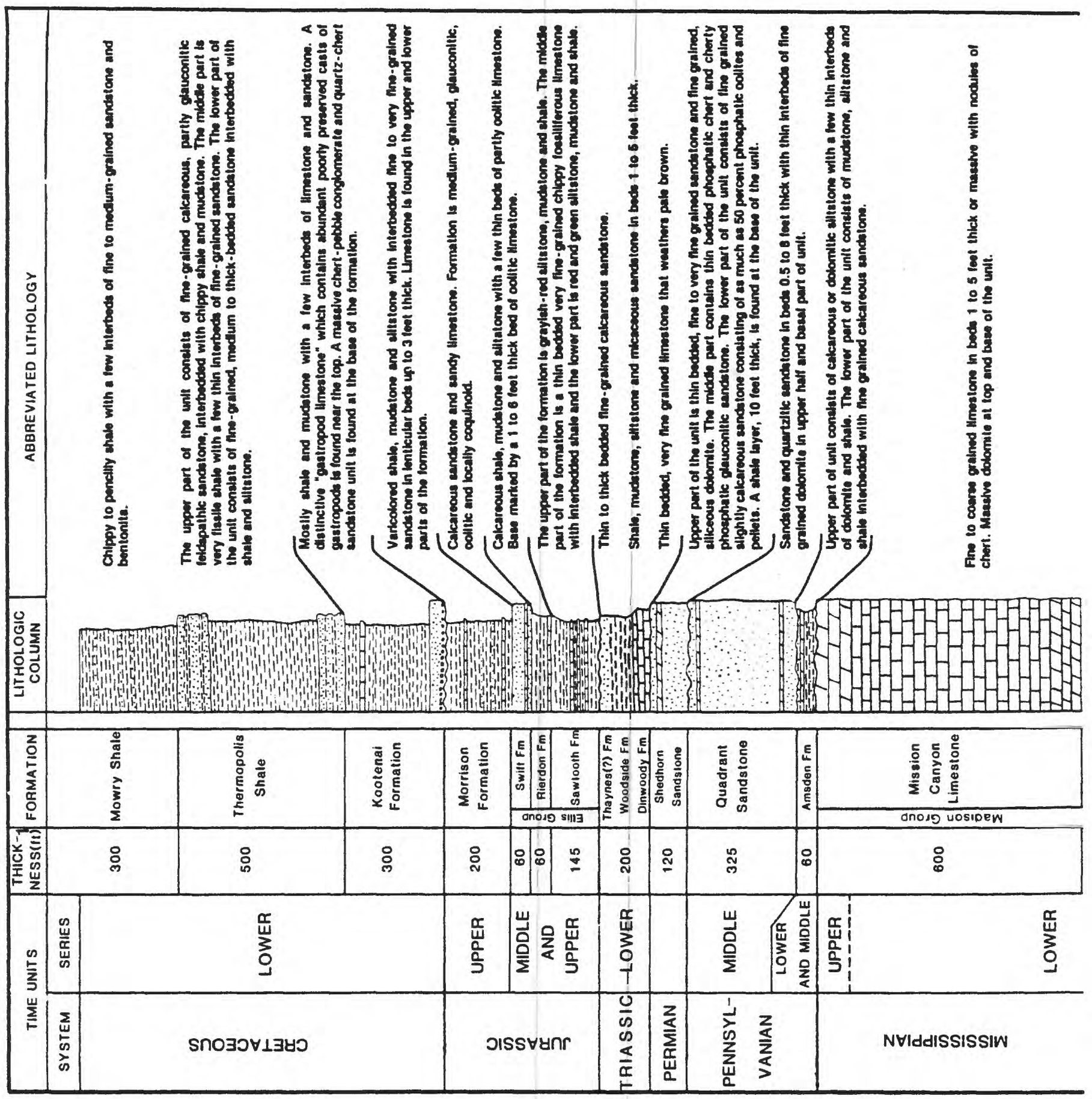



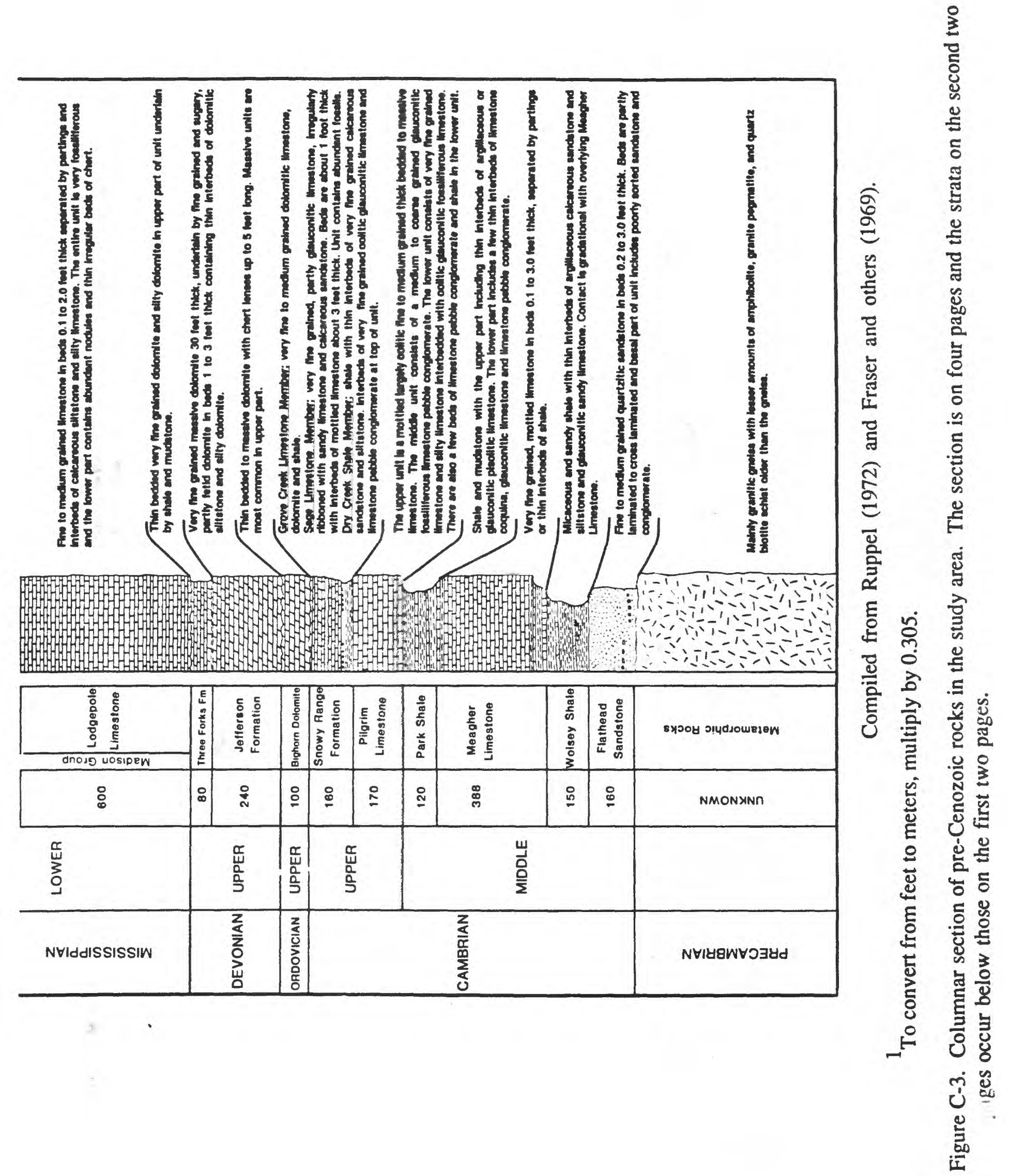


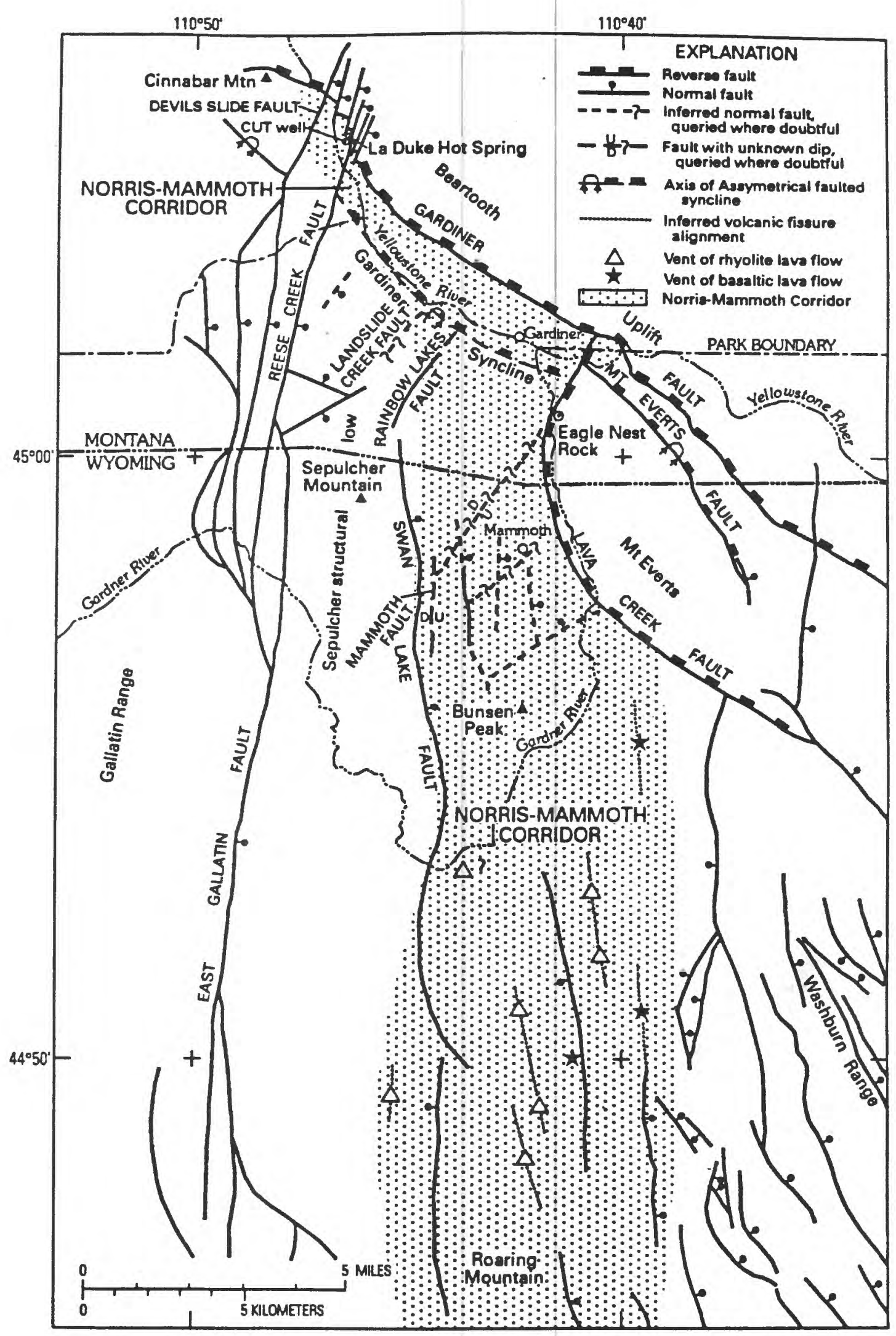

Figure C-4. Important structures in the Roaring Mountain-Mammoth-La Duke area (based on figure $\mathrm{C}-1$, but some minor faults distant from thermal areas are not shown). 
Although Fraser and others (1969) thought Quaternary reactivation along the Gardiner reverse fault was indicated by two levels of late Cenozoic basalt and by subparallel scarps on the travertine bench above Gardiner, we conclude that both the basalt and scarps are readily explained by nontectonic means. The higher level of basalt near Little Trail Creek (fig. C-6) was mapped by R.L. Christiansen (U.S. Geological Survey, written commun., 1989) as an older basalt, most likely the Junction Butte Basalt. The Junction Butte Basalt is mapped further south on the southeast side of Mt. Everts underlying the 2 Ma Huckleberry Ridge Tuff (fig. C-5; U.S. Geological Survey, 1972; Christiansen and Blank, 1972). This older basalt (Qob, fig. C-6) occurs at about the same height above drainage as the Huckleberry Ridge Tuff (fig. C-5), and thus its altitude above the Undine Falls Basalt (fig. C-5) is readily explained by an older age, and does not require faulting (fig. C-5). In the Mt. Everts area, the Junction Butte Basalt is normally polarized and stratigraphically beneath the 2 Ma Huckleberry Ridge Tuff (fig. C-5; R.L. Christiansen, U.S. Geological Survey, written commun., 1989). For the older basalt near Little Trail Creek, fluxgate magnetometer determinations on all flows measured (flows 1, 3, 4, and 5) also indicated normal polarity. In this report, we designate the Huckleberry Ridge Tuff and Junction Butte Basalt as Quaternary (Q) consistent with most published reports on the area; more recent definition of the start of the Quaternary as about 1.65 Ma, as discussed by Richmond and Fullerton (1986), would place these units in the Pliocene.

A fundamental problem with the hypothesis of Fraser and others (1969) that the northeastdipping Gardiner reverse fault was reactivated by normal faulting is that normal displacement on this fault should result in downdropping to the north, whereas the postulated offset is down to the south. A normal fault having down-to-the south offset could not be coplanar with the north-dipping Gardiner reverse fault.

Fraser and others (1969) also thought the subparallel scarps on the travertine bench were crustal faults associated with down-to-the south normal faulting on the Gardiner reverse fault, as rejected above. These scarps are readily explained by surficial slumping of the 300 -m-high travertine bench towards the Yellowstone valley, facilitated by and parallel to strike of the underlying incompetent Cretaceous bedrock (Pierce, 1973a; Struhsacker, 1976).

\section{Lava Creek Reverse Fault}

The Lava Creek reverse fault (fig. C-4) trends northerly near the foot of Mt. Everts and dips east (Ruppel, 1972; U.S. Geological Survey, 1972). We extend the Lava Creek reverse fault from its previously mapped northern limit near the Wyoming-Montana State line northward to the Gardiner reverse fault (fig. C-1) on the basis of the following, from south to north: (1) a fault required between Cody Shale and Landslide Creek Formation $1.5 \mathrm{~km}$ south-south-west of Eagle Nest Rock, (2) rollover of gently dipping beds on Mt. Everts to dips of up to $60^{\circ}$ along the Gardiner River just west of Eagle Nest Rock (fig. C-4), (3) small-scale reverse faults exposed in the high road cut $0.5 \mathrm{~km}$ south of Eagle Nest Rock that strike N5 $5^{\circ} \mathrm{E}$ and dip $65^{\circ} \mathrm{E}$ with polished shale and slickensides on carbonate vein filling inclined $60^{\circ}$ to the $S 60-70^{\circ} \mathrm{E}$, (4) telluric and other geophysical anomalies indicating a fault $1.5 \mathrm{~km}$ southeast of Gardiner, and (5) the high-angle fault 


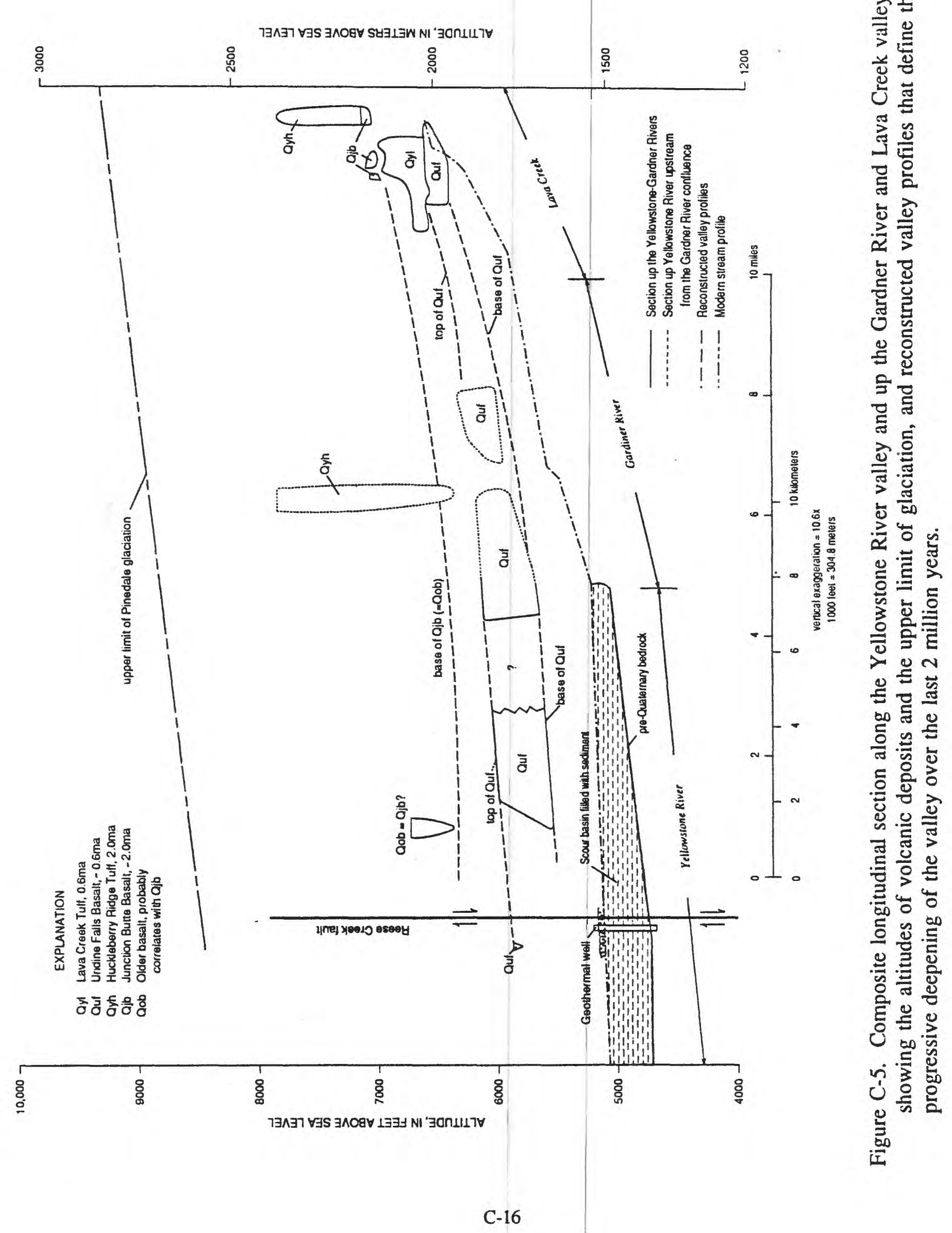




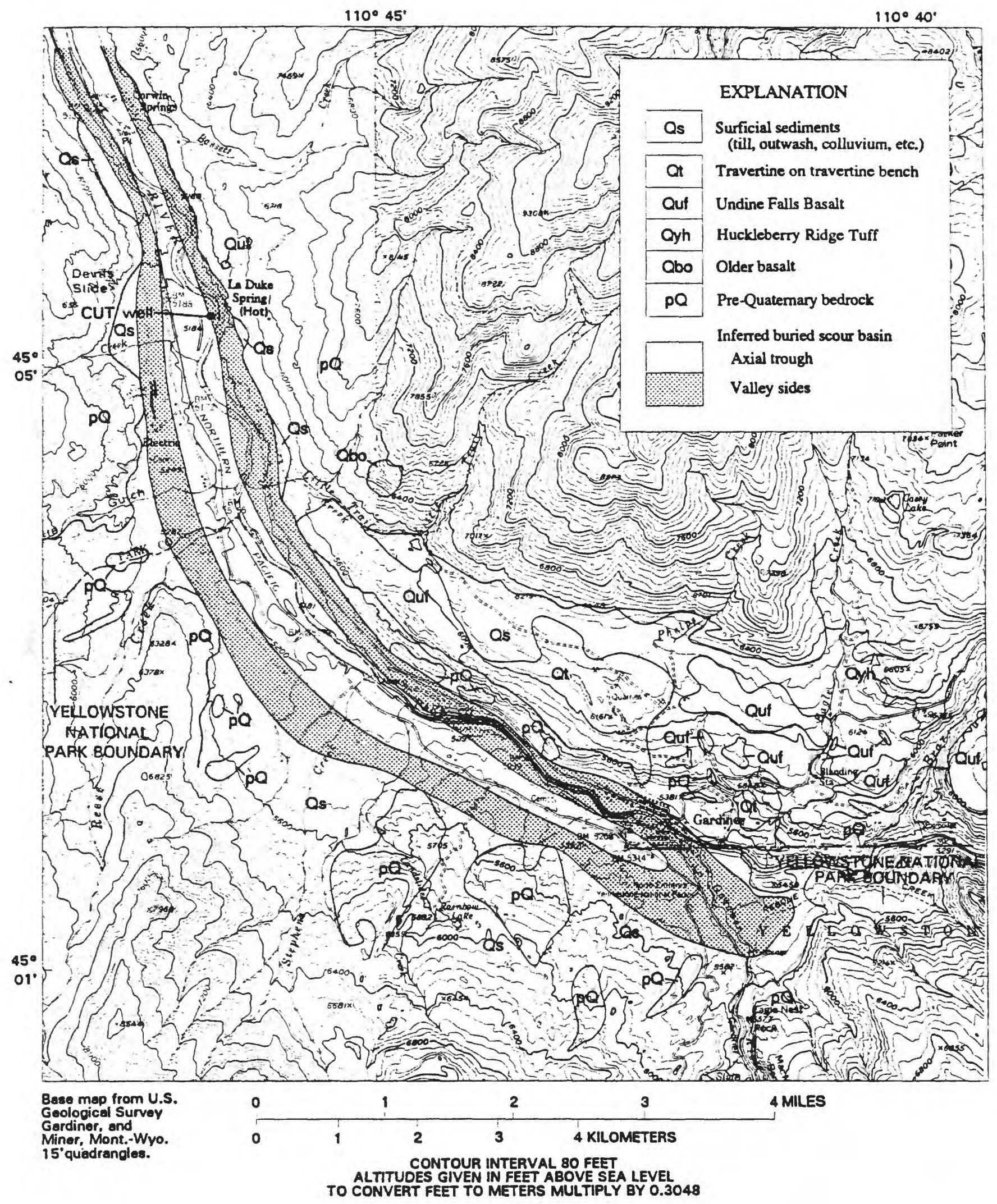

Figure C-6. Map showing location of postulated glacial scour basin extending from Gardiner to below La Duke Hot Spring. The darker shading brackets the deeper part of the trough. We interpret the well log for the geothermal well drilled for the Church Universal and Triumphant to indicate that the scour basin there is $130 \mathrm{~m}$ ( $430 \mathrm{ft}$ ) deep $0.2 \mathrm{~km}$ southwest of La Duke Hot Spring. 
mapped north of the Yellowstone River by Fraser and others (1969) as west side down that has changes in trend with changes in topographic slope that indicates it is an east-dipping reverse fault. The entire trace of what we show as the Lava Creek fault in Montana is the same as that mapped by Fraser and others (1969), but called by them the Mammoth fault.

\section{East Gallatin-Reese Creek Normal Fault System}

The East Gallatin normal fault (fig. C-4; Ruppel, 1972) forms a northerly trending escarpment up to $600 \mathrm{~m}$ high. Ruppel (1972) shows that northward on this trend, this fault branches into a set of east-dipping faults with as many as five strands. The Reese Creek fault is the eastern major strand of this system and has more than $1.2 \mathrm{~km}$ of stratigraphic displacement (Wilson, 1934). The southeast escarpment of Cinnabar Mountain is controlled by the Devils Slide fault, the western main fault in this system. From Cinnabar Mountain southeast towards La Duke Hot Spring, this fault system downdrops the Gardiner syncline to increasingly greater depths.

This fault system offsets the Gardiner fault as well as Eocene volcanic rocks, and is thus of younger Cenozoic age (Ruppel, 1972; Struhsacker, 1976). A small basalt remnant of 0.6 Ma Undine Falls Basalt (fig. C-6) occurs downvalley across the Reese Creek fault but is apparently not offset within the limits of resolution, which is about $50 \mathrm{~m}$ (fig. C-5). We could find no post-glacial fault scarps along this fault system.

Near La Duke Hot Spring, the Reese Creek fault zone consists of several strands (fig. C-4; Struhsacker, 1976). La Duke Hot Spring occurs about on what is drawn as the throughgoing strand of the Reese Creek fault zone and $100 \mathrm{~m}$ south of the Gardiner reverse fault (figs. C-1, C-4). Such a fault trend through La Duke is supported by an alignment of hot springs and streambedtemperature anomalies that trend southward from La Duke along the Yellowstone River (Hamilton and Chambers, this volume). Forty meters northeast of La Duke, a vertical quartzite bed forms a strike ridge important to definition of where the La Duke Spring occurs relative to the geologic section (fig. C-3). On the riverward side of this ridge occur elongate nodules of tubular chert like that in the Shedhorn Sandstone. On the valley wall side of the ridge are small exposures of tan and pink mudstone. Although the sedimentary rocks are strongly altered by geothermal solutions and probably sheared and thinned by faulting, we think the main quartzite is the Pennsylvanian Quadrant Sandstone overlain on its riverward side by the Permian Shedhorn Sandstone (see fig. C-3).

\section{Norris-Mammoth Corridor}

The Norris-Mammoth corridor (figs. C-1, C-4) is a structural zone that extends north from Norris Geyser Basin through Mammoth Hot Springs to La Duke Hot Spring on the Gardiner fault (Eaton and others, 1975; Smith and Braile, 1984; White and others, 1988). Struhsacker (1976) used the term Norris-Corwin Springs corridor, making prominent the inclusion of La Duke Hot Spring. The primary basis for the corridor's definition is somewhat ambiguous and varies with authors. For the purpose of this report, we emphasize that the corridor is characterized by both a north-south 
concentration of active and inactive geothermal features and, south of Bunsen Peak, by a belt containing 9 exposed rhyolite and basalt vents (fig. C-4) and about 5 additional buried vents, nearly all of which erupted after $0.6 \mathrm{Ma}$. Northerly trending normal faults, also active since $0.6 \mathrm{Ma}$ occur within and tend to bracket this corridor. In addition, the volcanic vents can be interpreted to lie on trends parallel to the normal faults. These vents are likely to occur along extensional faults or fissures although such features, if present, have not been identifiable, perhaps because of their burial by younger volcanic rocks and glacial deposits or because of only minor offset. On the basis of the north-south alignment of normal faults that indicate the trends of extensional features in the area, figure C-4 shows inferred volcanic fissures drawn approximately north-south through vent locations and locally connected with other vents or ends of mapped normal faults. Although inferred, this probable north-south alignment of fissures parallel to the length of the corridor is important to consider both in relation to the flow of geothermal fluids in the corridor and to the injection of subsurface dikes associated with the volcanism in the corridor.

Eaton and others (1975) place both Norris Geyser Basin and Mammoth Hot Springs on the eastern boundary of the corridor, and thereby exclude many vents and geothermally altered areas; they also extend the western boundary to the east Gallatin fault, thereby including a $5 \mathrm{~km}$ wide band without geothermal alteration and volcanic vents. For its east-west extent, our concept of the corridor is similar to that of White and others (1988) and R.L. Christiansen (U.S. Geological Survey, written commun., 1991). For its north-south extent, all place the northern margin of the corridor to include at least some of the hot springs and travertine deposits near the Gardiner fault.

The Norris-Mammoth corridor extends about $40 \mathrm{~km}$ northward from the 0.6-Ma Yellowstone caldera margin (figs. C-1 and C-4). The corridor contains the only major alignment of volcanic vents and geothermally altered areas in the Yellowstone area that lie outside this caldera (Christiansen, 1984, fig. 6.7). The corridor is marked by an electrically conductive upper crust from its southern limit at the caldera boundary to just south of Bunsen Peak, indicating intense alteration associated with geothermal fluids (Stanley and others, this volume).

The Norris-Mammoth corridor forms a linear appendage tied to the $0.6 \mathrm{Ma}$ Yellowstone caldera by volcanic, magmatic, geothermal, and structural features and extending about a caldera diameter away from it. A similar appendage extends northward from the Long Valley caldera in California and is demarcated by the Inyo and Mono alignment of volcanic vents; Bursick and Sieh (1989) showed that extension alternated in time between faulting on the eastern front of the Sierra Nevada Range and dike intrusion beneath the Inyo-Mono alignment.

As shown in figure C-7, structures associated with the Norris-Mammoth corridor and the East Gallatin-Reese Creek fault system are likely to intercept at depth. The dikes feeding the 14 volcanic vents in the Norris-Mammoth corridor were injected from depth. If, as likely, the least principal stress is horizontal, their dip would be vertical. Assuming that East Gallatin normal fault has an east dip of about $50^{\circ}$, typical of basin-range faults in the region (Barrientos and others, 1987), and dikes and fissures are vertical, it would intersect the feeder dike system at 8-12 km. The actual 


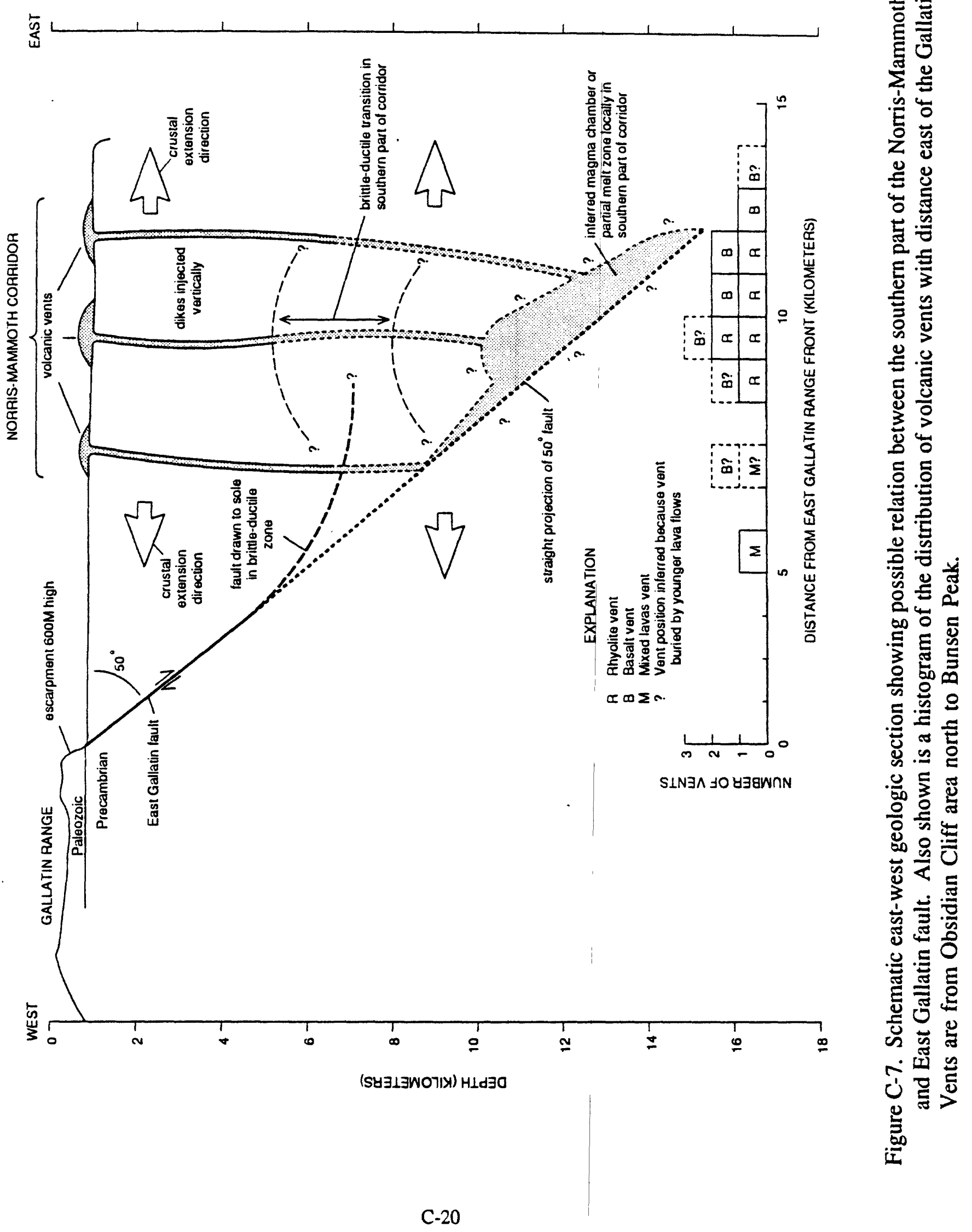


intersection is likely to be shallower (dashed line, fig. C-7) if the east Gallatin fault soles into ductile material estimated to be at depths of $6-7 \mathrm{~km}$ (Stanley and others, this volume). These two structures may also be closely related in that they both appear to accommodate east-west extension. Dike intrusion in the Mammoth-Norris corridor reflects east-west extension as does normal fault movement on the East Gallatin-Reese Creek fault. We have observed no post-glacial offset on the East Gallatin-Reese Creek fault system and no post-glacial tensional opening in the Norris-Mammoth corridor. The probable time of latest major extension in the corridor was 80-320 ka when about 70 percent of the volcanic vents erupted. Historic altitude changes have occurred in the corridor with local relative uplift of $0.5 \mathrm{~m}$ in the 1923-60 interval (Reilinger and others, 1977). Modeling of magnetotelluric sounding data indicates that south of Bunsen Peak the corridor is characterized by near magmatic temperatures below depths of 6-7 km (Stanley and others, this volume).

\section{Structures in the Mammoth Area}

The location and continuity of regional structures in the Mammoth Hot Springs area are poorly understood. This is because of a combination of poor exposures, abundant landsliding, and cover by Quaternary glacial deposits, volcanic rocks, travertine, and Eocene volcanic rocks.

What is clear is that the Mammoth Hot Springs area is located on a structural high. The Jurassic outcrops near Mammoth Hot Springs indicate structural elevation of about half a kilometer relative to Cretaceous rocks exposed within. $2 \mathrm{~km}$ north, east, or south. Ruppel (1972; fig. C-4) showed that a major structure, which he called the Mammoth fault and inferred to be north-trending, occurs somewhere west of Snow Pass, which is $3 \mathrm{~km}$ southwest of Mammoth. This fault elevates Jurassic rocks exposed at Snow Pass above Upper Cretaceous rocks exposed along the Gallatin Range front, $5 \mathrm{~km}$ further west. Section EE' (fig. C-2) shows this fault with $1 \mathrm{~km}$ uplift on its east side. As noted by Ruppel (1972, p. A53), the southward continuation of the uplifted (eastern) side of the Mammoth fault is probably indicated by the band of outcrops of Paleozoic rocks that extend from Roaring Mountain for $12 \mathrm{~km}$ to the north (fig. C-1); this trend also suggests a roughly northward strike for the Mammoth fault. South of the latitude of Snow Pass, no pre-Eocene rocks are exposed between this inferred structural high west and the Gallatin Range, thus preventing firm definition of the location and strike of the Mammoth fault of Ruppel (1972).

A north-striking extension of the Mammoth fault into Montana is not recognized, as no large changes in structural level are known in the area containing patchy exposures of Cretaceous Landslide Creek Formation that extend from $2 \mathrm{~km}$ due south of Gardiner for $8 \mathrm{~km}$ northwest to the Reese Creek fault. A northeast continuation of the Mammoth fault is postulated by Ruppel (1972) to strike north or northeast towards what we have mapped as the northern extension of the Lava Creek reverse fault (fig. C-4). Between the Reese Creek fault and this possible northeast-trending Mammoth fault, no major offset has affected the basal part of the Eocene volcanic sequence, indicating either that the Mammoth fault is older than Eocene, or that it strikes east of the easternmost Eocene volcanic exposure (Tvc, fig. C-1). 
The dip of the Mammoth fault is not known. It does not offset Quaternary deposits and is not recognized to offset Eocene rocks. Consequently, it conceivably could be Laramide in age and be an east-dipping reverse fault. The trace of the Mammoth fault inferred by Ruppel (1972) is close to a north-south normal fault, here named the Swan Lake fault, which passes just west of Snow Pass and has $50 \mathrm{~m}$ of down-to-the-east offset of Quaternary and Eocene volcanic rocks (fig. C-1; U.S. Geological Survey, 1972; R.L. Christiansen, written, commun., 1989). The Swan Lake fault is the only fault with demonstrated Quaternary movement in the Mammoth area. If the Mammoth fault were a reverse fault and dipped east, this normal fault might represent the actual trace of the Mammoth fault with extensional "backsliding" on it, thus providing a unifying explanation for older down-to-the-west faulting and younger down-to-the-east faulting in essentially the same place.

The possibility that the Swan Lake and Mammoth faults may represent compressional deformation followed by extensional deformation on the same fault is supported by such a history being determined for the better exposed Buffalo Fork thrust (Love and Keefer, 1975), which is located southeast across the Yellowstone calderas from the south end of the Norris-Mammoth corridor. There, Laramide thrusting with relative uplift of about $3 \mathrm{~km}$ on the east side of the thrust was followed by late Cenozoic normal faulting with the east side relatively down about $500 \mathrm{~m}$.

\section{Sepulcher Structural Low}

A north-trending structural low exists between the East Gallatin-Reese Creek fault system and the Mammoth fault (Ruppel, 1972; Struhsacker, 1976). This has been has been called the Sepulcher Mountain graben for Sepulcher Mountain, which preserves about $1 \mathrm{~km}$ of Eocene volcanic rocks in this structural low. If the Mammoth fault bounding the east side of this low is a reverse fault, then the term graben would be inappropriate; thus we use the designation Sepulcher structural low.

The structural depth of the Sepulcher structural low south of Sepulcher Mountain is poorly defined because pre-Cenozoic rocks are exposed there in only one area. Ruppel (1972) maps Upper Cretaceous Telegraph Creek Formation along the Gardner River west across two strands of the East Gallatin-Reese Creek fault system from the Sepulcher structural low (figs. C-1, C-3, and C-4). Between these two fault strands, undifferentiated Upper Cretaceous rocks are mapped by the U.S. Geological Survey (1972; shown as Cretaceous on fig. C-1). Based on the fault offset, these outcrops would be higher in the Cretaceous than the Telegraph Creek. The Sepulcher structural low is across another fault whose offset would place the stratigraphic level there even higher in the Cretaceous section. For the geologic sections (fig. C-2), we have assumed this part of the Sepulcher structural low contains Cretaceous strata as high as the lower part of the Everts Formation (fig. C-3).

\section{Surficial Geology and Thermal Features}

Volcanic rocks in the valleys of the Yellowstone and Gardner Rivers record different stages in the erosion of these valleys (fig. C-5; volcanic rocks mapped and described by R.L. Christiansen, 
(written commun., 1989; Christiansen and Blank, 1972; U.S. Geological Survey, 1972). The amount of downcutting from the top of the volcanic fill represented by the volcanic deposits is: (1) for the older basalt (Junction Butte? = $2 \mathrm{Ma}$ ), as much as $500 \mathrm{~m}(2)$ for the $0.6 \mathrm{Ma}$ Undine Falls Basalt, as much as $275 \mathrm{~m}$. The net downcutting is only about half these amounts because it is referenced to the valley floors down which these basalts flowed and does not include the thickness of the basalt valley fills that had to be recut (fig. C-5.). The net downcutting is as follows: (1) since just prior to the 2?-Ma Junction Butte Basalt, about $300 \mathrm{~m}$, and (2) since just prior to the 0.6-Ma Lava Creek Tuff, about 75-125 m. This history of erosion provides limiting ages for the travertine deposits in the area. These depths of incision in the study area are much deeper than on the Yellowstone Plateau south of Mammoth where the 2 and $0.6 \mathrm{Ma}$ volcanic tuffs commonly occur within $100 \mathrm{~m}$ of the present drainages (fig. C-5).

\section{Glaciation and Geothermal Systems}

A large icecap formed on the Yellowstone Plateau and surrounding mountains during the last major glaciation, which climaxed between about 20-40 thousand years ago (ka) and had largely receded by about $11 \mathrm{ka}$, (Pierce, 1979). Glacial flow from the northern part of this thick ice cap converged towards Gardiner to form a major outlet glacier that flowed to its terminus $65 \mathrm{~km}$ further downvalley near Chico Hot Springs. At Gardiner, the ice thickness was about 1,100 m (fig. C-5); at Mammoth Hot Springs, it was about $800 \mathrm{~m}$; southward from Mammoth above the NorrisMammoth corridor it was 700-800 m (Pierce, 1979).

Beneath this glacial ice, pressures on geothermal systems probably were increased due to water in and at the base of the glacier. The water pressure at the base of a glacier varies in both space and time as summarized by Patterson (1980). More than several kilometers from the glacier terminus, hydrostatic head at the base of the glacier are typically between 50 and 90 percent the ice thickness (Patterson, 1980; Andrew Fountain, oral commun., 1990). For carbonate-rich waters, these increased pressures near the ice-ground interface are likely to have favored $\mathrm{CO}_{2}$ transport rather than carbonate deposition in the shallow parts of the geothermal system now depositing travertine at Mammoth, La Duke, and other areas. Thus for the Mammoth-La Duke area, the time of deglaciation about 12-15 ka (Pierce, 1979) is the starting time for the present cycle of carbonate buildup.

From Gardiner downstream to below La Duke Hot Spring, flow of the northern Yellowstone outlet glacier apparently scoured a basin more than $100 \mathrm{~m}$ below present river level (fig. C-6). Upon deglaciation, a lake formed in this basin and rapidly filled with fine-grained sediment. Along the Yellowstone River within about half a mile upstream and downstream from La Duke, lake sediments are exposed from the river bed up to about $8 \mathrm{~m}$ above the river. These lake sediments have zones of ripple-bedded sand overlying contorted and rolled lake sediments, interpreted to represent glacially dammed floods surging through the lake. Except where being actively undercut by the Yellowstone River, exposures of these unconsolidated lake sediments are typically obscured by colluvium from the overlying flood deposits. 
These lake sediments with interbeds of flood sands probably extend more than $100 \mathrm{~m}$ below the present river level, as indicated by our interpretation of the $\log$ of the CUT geothermal well, located across the Yellowstone River from La Duke Hot Spring (fig. C-6). This well has been inferred to have been drilled largely in shale (Hydrometrics, 1986), apparently assuming that the "blue mud" described in the drill logs was the same as nearby exposures of Cretaceous shales. We interpret the well $\log$ to indicate the following, based on (1) discussions with the driller, William Kupfer (original well log, 1986; oral commun., 1989), (2) exposures in the nearby riverbanks, and (3) the log of the nearby Miller geothermal well:

$\begin{array}{ll}\text { Depth } & \text { Description and interpretation } \\ 0-9 \mathrm{~m} & \begin{array}{l}\text { Gravel and sand. Same as bouldery flood gravels exposed in river } \\ \text { banks nearby. } \\ \text { Blue mud. Drilled with water because could not be drilled with air. }\end{array} \\ \text {-128 m } & \begin{array}{l}\text { Unconsolidated lake sediments with sand layers, as noted in nearby } \\ \text { Miller well. } \\ \text { Bedrock, rock type not known. Material below } 128 \mathrm{~m} \text { drilled much } \\ \text { differently than that from 9-128 m. Circulation was lost at } 128 \mathrm{~m} \text { and } \\ \text { drilling switched to air. }\end{array}\end{array}$

Shallow movement of geothermal fluids in the area of the geothermal well would be affected by this scour basin and its fine-grained sedimentary fill. The fill of interbedded lake sediments and more permeable sandy interbeds probably has horizontal permeability in the sandy beds, whereas vertical permeability is restricted by the clayey beds. This fill would tend to act as a blanket over the underlying bedrock, with localized upward permeability controlled by the old valley wall and perhaps upward penetration only where conduits have become established above fault zones in the bedrock. Two zones of hot springs near river level, one upstream and one downstream from La Duke Hot Spring, are aligned along branches of the Reese Creek fault system (Hamilton and Chambers, this volume; Sorey and others, this volume). When the Yellowstone River was at very low water, two springs were observed venting through these lake sediments south of La Duke Hot Spring.

\section{History of Travertine Deposition}

In the northern part of the Norris-Mammoth corridor, travertine deposits exist in a north-south band $25 \mathrm{~km}$ long that broadens along its northem margin to a width of $10 \mathrm{~km}$ along the northwest trending Gardiner reverse fault (fig. C-8, table C-1). Table C-2 lists 20 uranium-thorium ages obtained on these travertine deposits. These ages were determined by measuring the radioactive disequilibrium between travertines, using a modification of the method described by $\mathrm{Ku}$ and Liang (1984). Following a preliminary set of measurements by alpha spectrometry, a subset of samples was selected for high-precision analyses by thermal ionization mass spectrometry (table C-2). The Th and U isotopic analyses were performed by N. Sturchio (Argonne National Laboratory) and M. Murrell 


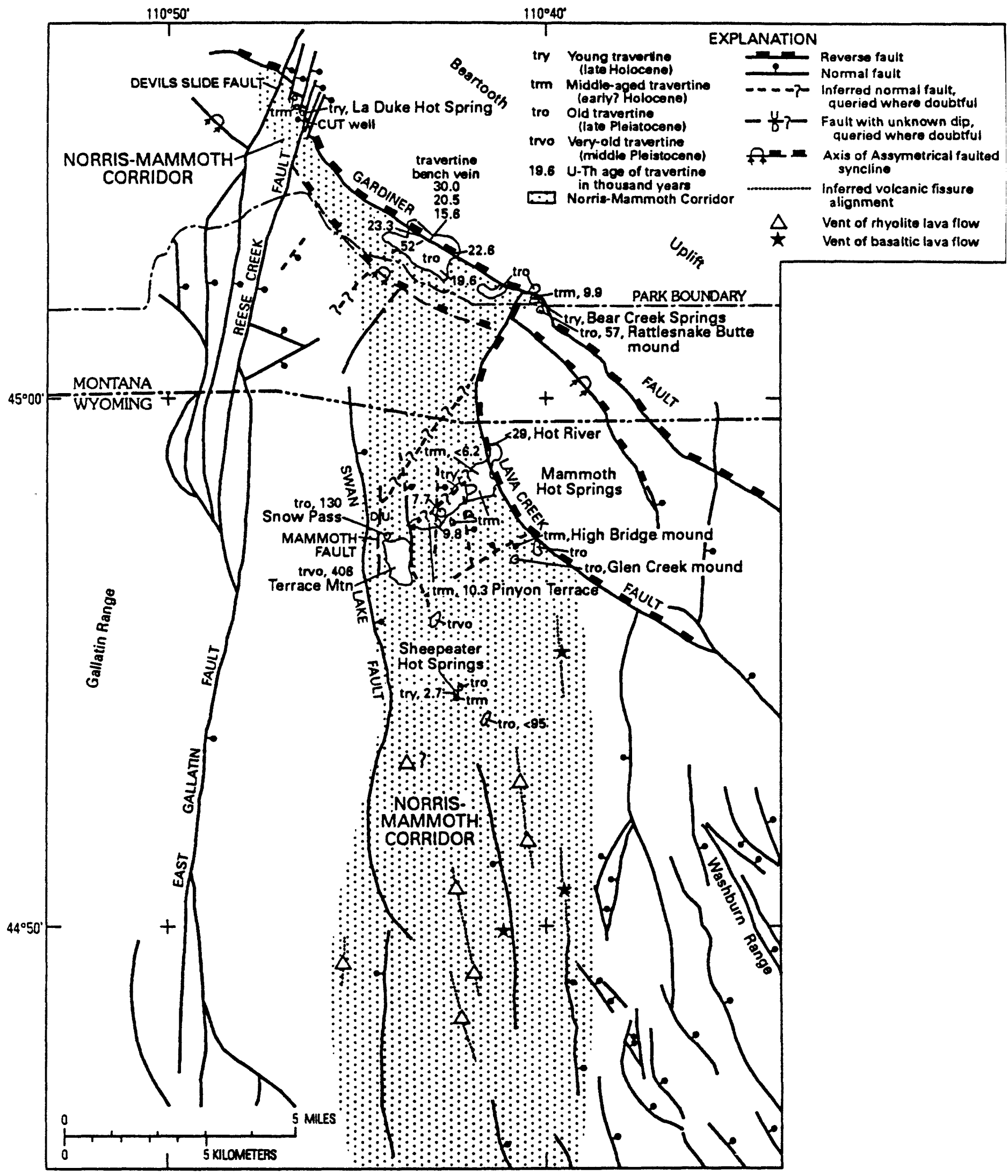

Figure C-8. Thermal springs, travertine deposits and their ages, and relation of these thermal features to geologic structures in the Mammoth-La Duke area. 
(Los Alamos National Laboratory), using the mass spectrometric technique described by Goldstein and others (1989). Ages are given with $2 \sigma$ errors.

Travertine deposition in this area has occurred over at least the last four hundred thousand years. Field relations and radiometric dating indicate five ages of travertine deposition (fig. C-8; tables C-1, C-2) which in the following descriptions are numbered 1 (youngest) to 5 (oldest) and thence described from north to south.

1. Young travertine (try, fig. C-8) shows evidence of ongoing deposition, including the active and recently active La Duke, Bear Creek, Mammoth, and Sheepeater Hot Springs. Most of this travertine is less than a few thousand years old. The travertine deposits in large accumulations of "try" may be significantly older as shown by the U-Th age of $7.72 \pm 0.88 \mathrm{ka}$ from a depth of $72.8 \mathrm{~m}(239 \mathrm{ft})$ in the $\mathrm{Y}-10$ drill hole in the upper part of the active terrace at Mammoth Hot Springs.

2. Middle-aged travertine (trm) shows no evidence of ongoing deposition, is locally covered by vegetation including trees, but does not have glacial erratics on it. Such deposits include two small mounds just north of La Duke Hot Spring and the large mound at Bear Creek Springs, the top of which has a U-Th age of $9.92 \pm 0.07 \mathrm{ka}$. At Mammoth Hot Springs, two large deposits of this general age are present. First, Pinyon Terrace (Barger, 1978) has an inactive front 200 feet high; a sample from the top of this front has a U-Th age of $10.29 \pm 0.18 \mathrm{ka}$; one from the base is $9.76 \pm 0.07$. Second, a large sheet of travertine extends below the active part of Mammoth Hot Springs for $1.8 \mathrm{~km}$ downslope to the Gardner River; U-Th ages on two samples provided only maximum ages (fig. C-8), but these are compatible with ages in the 3-10 ka range. Small deposits of "trm" occur along the Gardner River upstream from the High Bridge as well as in the Sheepeater Canyon. The deposit of "Qtm" $0.4 \mathrm{~km}$ north of the Glen Creek mound overlies organic material with a carbon-14 age of $2170 \pm 90$ years before present (W.L. Hamilton and P.J. Conn, National Park Service, written commun., 1989).

3. On the travertine bench above Gardiner, two ages of travertine, both designated "tro" and mantled by till deposited during the last glaciation (Pinedale), are apparent from the U-Th ages, the younger of which is included in this group. Subaerial travertine with ages of $19.57 \pm 0.12,22.64$ \pm 0.17 and a vent vein with an age of $23.34 \pm 0.28$ are mantled by Pinedale glacial deposits and may represent travertine deposition during a time of recession between Pinedale full glacial time $(>20 \mathrm{ka}$ ) and a later readvance called the Deckard Flats readjustment. Above the $22.64 \mathrm{ka}$ sample, a 10-20 cm thick gravelly bed represents some break in travertine deposition, and may indicate the presence of a glacier nearby.

4. Near Gardiner, older ages were obtained on travertine designated "tro" (fig. C-8) from beneath Pinedale glacial deposits as follows: $52 \pm 5 \mathrm{ka}$ from near the base of the section on the travertine bench, and $57.11 \pm 0.59 \mathrm{ka}$ for the large, half-eroded travertine mound (Rattlesnake Butte mound, tro) across the Yellowstone River from Bear Creek. South of Bunsen Peak and Sheepeater Canyon, travertine (tro) mantled by Pinedale glacial erratics has a U-Th age of $<95 \mathrm{ka}$. An interval of glaciation is expected to be represented in the vertically exposed section between the samples with ages of $52 \mathrm{ka}$ and $23.3 \mathrm{ka}$, but no unconformity was observed. No older travertine 
(tro) including that which might be in the 50-60 ka range is known near Mammoth Hot Springs, although Mammoth is thought to have been ice-free at this time, based on a stratigraphic section at McMinn Bench (0.6 km south of Eagle Nest Rock; Pierce, 1973a, 1979). The McMinn Bench section indicates that the glacier flowing down the Yellowstone River was about $300 \mathrm{~m}$ thick near Bear Creek when an ice-dammed lake existed in the lower part of the Gardner River valley. On the travertine bench at the stratigraphic level of the sample dated $52 \pm 5 \mathrm{ka}$, concentric layers of a geode-like vein yielded ages of $30.06 \pm 0.30,20.48 \pm 0.17$ and $15.58 \pm 0.13 \mathrm{ka}$; this vein accumulated after the enclosing travertine, dated at about $52 \mathrm{ka}$, was deposited and in part may have accumulated when the overlying travertine was covered with glacial ice.

5. The very old travertine (trvo, fig. C-8) of Terrace Mountain has a U-Th age of $406 \pm 30 \mathrm{ka}$. Pinedale glacial deposits occur on this travertine. The horizontal layering of this travertine at the east edge of Terrace Mountain indicates that it was deposited on a landscape without the present deep valley immediately to the east where the travertine of Mammoth Hot Springs has more recently accumulated. The U-Th age indicates that Terrace Mountain is considerably older than the major glaciation (Bull Lake, approximately $140 \mathrm{ka}$, Pierce and others, 1976) that preceded the last major glaciation (Pinedale).

This age information on travertine indicates several points. Travertine has accumulated in the region since at least $400 \mathrm{ka}$, but ages for deposits from different areas do not show strong overlap in time (fig. C-8; tables C-1, C-2). From about 0-10 ka, a large amount of travertine has accumulated in the Mammoth area, but none accumulated on the travertine bench near Gardiner, and little accumulated at Bear Creek Springs. From $10 \mathrm{ka}$ probably back to the time of deglaciation at about 12-15 ka, travertine accumulated near the mouth of Bear Creek and on the Pinyon Terrace above Mammoth Hot Springs. Only a minor amount of travertine has accumulated at La Duke, probably within the last few thousand years, and inactive small mounds of Holocene travertine occur 0.45 and $0.7 \mathrm{~km}$ downstream from La Duke (fig. C-6). Across the Yellowstone River from La Duke Hot Spring near Spring Creek, carbonate cementation of Pinedale flood gravels suggests percolation of carbonate-rich thermal(?) waters in post-glacial time ( $<12-15 \mathrm{ka})$ through the valley fill blanketing the Reese Creek fault. From about 19 to $23 \mathrm{ka}$, the travertine bench near Gardiner was active, but no travertine of that age is known from the Mammoth area, a point of possible geothermal significance discussed below.

The travertine bench and the Rattlesnake Butte mound were active about 50-60 ka, but no deposits of this age are known near Mammoth. The 60-m-high Rattlesnake Butte mound probably took thousands of years to accumulate prior to final deposition about $57.11 \pm 0.59 \mathrm{ka}$ (fig. C-8). The present course of the Yellowstone River north of this mound appears to have been cut after construction of this mound because (1) the post-glacial river has incised $50 \mathrm{~m}$ into bedrock as well as eroded the northern half of the mound, and (2) south of the mound is an open valley the size of the Yellowstone River. This change is position probably occurred when the Yellowstone River was reestablished upon deglaciation of the area about 11 and $15 \mathrm{ka}$. Thus, when this mound was active, it probably was on the north side of the Yellowstone River in a topographic position quite similar to the Bear Creek travertine mound that was constructed in post-glacial time. 
Upslope from Mammoth Hot Springs at the north end of Terrace Mountain, a veinlet of travertine with a U-Th age of $134 \pm 3$ accumulated in glacio-fluvial kame gravels of probable Bull Lake age. Ten $\mathrm{km}$ south of Bunsen Peak, travertine is mantled by Pinedale till and records the southernmost known accumulation of travertine in the Norris-Mammoth corridor sometime between probably 50 and $95 \mathrm{ka}$.

\section{Hydrothermal Systems and Their Possible Interconnections}

This section discusses the structural and stratigraphic controls as well as the Quaternary geologic history that appear important to localization of the geothermal features in the study area, and to possible interconnections between Mammoth Hot Springs and geothermal features in the Corwin Springs KGRA. In this report, we use the term hydrogeologic connection to indicate a continuous permeable zone(s) (aquifers) between thermal areas that could transmit thermal fluid from one area to another, provided that a positive gradient in head exists. We use the term hydraulic connection to indicate that thermal fluids do flow through an aquifer system from one thermal area to another.

Kharaka and others (this volume) discuss the possibilities that hydraulic connections exist between La Duke Hot Spring and Mammoth Hot Springs and between Bear Creek Springs and Mammoth Hot Springs, on the basis of comparisons of geochemical and isotopic characteristics of thermal waters from each area. If geothermal development in the Corwin Springs KGRA resulted in significant changes in hydraulic head in production reservoirs, head changes could conceivably be transmitted to and affect Mammoth Hot Springs, unless geologic barriers exist that would not transmit such head changes. The purpose of the following discussion is to illustrate the nature of what seem to be plausible hydrogeologic connections based on current knowledge of the geology.

Permeable beds and faults, especially the intersections of faults, provide the conduits needed for the circulation of geothermal fluids. Active faulting can maintain permeability by breaking rock seals, but in the Corwin Springs KGRA-Mammoth Hot Springs area, only the Swan Lake fault has demonstrated Quaternary offset. Extensional normal faulting probably creates more permeability than compressional reverse faulting. Dissolution of carbonate rocks, particularly the Mission Canyon Limestone (Downey, 1984), may produce long-lasting permeability either parallel to bedding or where soluble carbonate units abut at least one side of a fault. For the thermal features in the northern Yellowstone boundary area, the travertine deposits themselves indicate enhancement of solution permeability in carbonate-rock conduits.

\section{La Duke-Bear Creek System}

The distribution of hot springs and travertine over a length of $12 \mathrm{~km}$ along the Gardiner fault and the adjacent near vertical syncline demonstrates that this combined structure is important to localization of hot springs (fig. C-8; tables C-1, C-2). Struhsacker (1976) concluded that the near- 
vertical beds on the northern limb of the Gardiner syncline would provide conduits for upwelling fluid, particularly in the Paleozoic carbonate rocks (fig. C-8, section DD). We favor the interpretation that the vertical limb of the syncline is more important than the Gardiner fault in localizing hot springs both because the Mission Canyon Limestone within the vertical limb is likely to have conduits in a favorable orientation for upflow, and because the springs tend to be located above the syncline rather than along the fault trace.

Currently (1991) discharge at La Duke Hot Spring is about $7 \mathrm{~L} / \mathrm{s}$ with additional discharge into the Yellowstone River yielding a total of $61 \pm 8.5 \mathrm{~L} / \mathrm{s}$ (Sorey and others, this volume). No modern hot-spring discharge is known from the Gardiner travertine bench. For the Bear Creek area, chemical studies of the Yellowstone River indicate a total thermal-water discharge of about $17 \mathrm{~L} / \mathrm{s}$ (Sorey and others, this volume).

Transverse faults that intercept the Gardiner fault as well as the vertical limb of the Gardiner syncline are important to the localization of thermal features (fig. C-8). La Duke Hot Spring and other hot springs southward along the Yellowstone River are located along the northern projection of the Reese Creek fault. A total of six faults are mapped along the northern valley wall in the $\mathrm{La}$ Duke area (fig. C-1).

Bear Creek Springs are located near the intersection of the Gardiner fault/syncline and a transverse fault which we show as the northem extension of the Lava Creek reverse fault and mapped earlier by Fraser and others (1976) and called by them Mammoth fault. Although Bear Creek Springs are $1 \mathrm{~km}$ east of the intersection of this fault with the Gardiner reverse fault (fig. C8), eastward downslope diversion of thermal waters at shallow depths is reasonable due to the Bear Creek site being more than $100 \mathrm{~m}$ lower as well as along strike in the Mission Canyon Limestone.

The travertine bench above Gardiner lies along the projection of two northeast-trending faults, the Landslide Creek and Rainbow Lakes faults (figs. C-1 and C-4). The mapped trace of the Rainbow Lake fault is at Rainbow Lakes about $2 \mathrm{~km}$ south of the Yellowstone River (U.S. Geological Survey, 1972) and of the Landslide Creek fault $200 \mathrm{~m}$ north of Yellowstone River (Fraser and others, 1976). Their recognition within a few kilometers south of the Yellowstone River (figs. C-1 and C-4) is based on electrical boundaries detected in telluric traverses (Stanley and others, this volume). Magnetotelluric soundings indicate deep-seated $(3 \mathrm{~km})$ zones of low resistivity associated with the Landslide Creek fault, as well as with the Reese Creek and Lava Creek faults near the northern Park boundary. Such zones may be related to hydrothermal fluid circulation at present or in the past.

The flow system(s) supplying thermal water to La Duke Hot Spring and Bear Creek Hot Springs might include: (1) flow from the south through Paleozoic rocks down the dip of the gentle southern limb of the Gardiner syncline, (2) flow from the south along conduits associated with north-trending Reese Creek fault system and the northeast-trending faults (the postulated northeast extension of the Mammoth fault and the northern part of the Lava Creek reverse fault), and (3) flow 
from the north through fractured Precambrian rocks of the Beartooth uplift. Struhsacker (1976) suggested possibility (1) with recharge about $15 \mathrm{~km}$ to the south, whereas Sonderegger (1987) preferred possibility (2), with extensional, graben-related faults providing zones of recharge to the deeper carbonate aquifer with preferential dissolution of limestone and dolomite adjacent to these faults. The simplified synclinal flow system diagramed by Struhsacker (1976) is complicated by other structures, in particular the north- and northeast-trending faults. Results of resistivity surveys, streambed-temperature measurements, and soil-mercury sampling along the northern boundary of the Park indicate that fault-related northerly flow of thermal water may now occur or have occurred along the Reese Creek, the Landslide Creek, and the Lava Creek faults (Stanley and others, this volume; Hamilton and others, this volume). Some of the water emerging at Bear Creek Springs and La Duke Hot Spring may have moved downward and then upward within the Gardiner fault zone and northern limb of the syncline. Geochemical evidence for reservoir rock types and conceptual models for flow systems supplying thermal water to these hot springs are discussed further in subsequent sections of the report. For Bear Creek Springs and La Duke Hot Spring, a dominant northerly source in the Precambrian Beartooth uplift is not favored because deep conduits are less likely than for the area to the south. However, data from strontium, lead, and neodymium isotopes suggest some influence of Precambrian schists but not the gneisses of the Beartooth uplift on the thermal-water chemistry of these springs (Kharaka and others, this volume).

The linear vent alignments of travertine deposits on the bench above Gardiner, particularly those in the western part, are clearly related to northwest-trending structures we attribute to slumping. These slump structures have postglacial topographic expression, offset the Undine falls basalt and are considered to be surficial slumps parallel to the high escarpment at the edge of the travertine bench and to bedding in the underlying bedrock (Pierce, 1973a; Struhsacker, 1976). Elongate mounds similar to Narrow Gauge vent at Mammoth are located along such slump scarps, some of which have rebroken in postglacial time. Emergence of waters on this bench $300 \mathrm{~m}$ above the level of Yellowstone River near the inferred outcrop of the vertical Mission Canyon Limestone may be explained by the presence of a glacier about $300 \mathrm{~m}$ thick at Gardiner which could have elevated the water table to the level of the travertine bench. The U-Th ages for the deposits on the travertine bench all relate to the times of likely partial glaciation, consistent with this idea.

\section{Mammoth System}

The present-day Mammoth system is an order of magnitude larger than any other system in the northern-boundary area, with a discharge near $590 \mathrm{~L} / \mathrm{s}$ (table C-1; Sorey and others, this volume). The original size of the Terrace Mountain deposit was similar to that for the postglacial Mammoth system, suggesting that large discharges also occurred from the Mammoth system about $400 \mathrm{ka}$ as well as from about $12 \mathrm{ka}$ to the present.

The travertines of Terrace Mountain and Mammoth have similar ${ }^{87} \mathrm{Sr}{ }^{86} \mathrm{Sr}$ values, which resemble that of modern Mammoth Hot Springs water, also suggesting that both were fed by the same hydrothermal system (Kharaka and others, this volume). For the Mammoth-Terrace Mountain 
system, the higher altitude and older geomorphic setting of travertine at Terrace Mountain and in Snow Pass suggest that the fundamental structure providing the upflow conduit may be as far west as the Snow Pass area (fig. C-8). For this area, the likely faults are either the pre-Quaternary downto-the-west Mammoth fault of Ruppel (1972), or the Quaternary down-to-the-east Swan Lake fault of R.L. Christiansen (U.S. Geological Survey 1972, written commun., 1989). As discussed earlier, if the Mammoth fault is an east-dipping reverse fault reactivated as the Swan Lake normal fault, these faults would be coplanar.

The extensive post-glacial travertine deposits east of Terrace Mountain that extend from Pinyon terrace down to the Gardner River could result from upflow along the Mammoth fault to shallow subsurface levels and then eastward diversion towards topographically lower sites. Channels for this shallow flow might be associated either with a postulated northeasterly fault coincident with the travertine alignment or with glacio-fluvial and/or travertine deposits beneath the valley floor east of Snow Pass. Subsurface hydrothermal activity in the Snow Pass area is suggested by gas vents there with elevated helium-isotope ratios indicating a source at great depths (Kharaka and others, this volume), by fresh collapse depressions a few meters across, and by a closed depression that held a pond $50 \mathrm{~m}$ across when the August, 1954 aerial photographs were taken, but now has underground drainage. Because Paleozoic rocks abut one side or the other of the Mammoth fault upward from a depth of $2 \mathrm{~km}$ (Section EE', fig. C-2), carbonate dissolution along the fault could have established open conduits upward from this depth. Upflow of thermal waters in the present-day Mammoth system might also occur along north-south faults mapped by Ruppel (1972) east of Terrace Mountain (figs. C-1 and C-4), but whose location and strike are poorly constrained .

\section{Travertine and Springs South of Mammoth}

South of the Mammoth Hot Springs, travertine deposits occur along the Norris-Mammoth corridor in and southeast of Sheepeater Canyon and along the Gardner River between Glen Creek and the High Bridge, but the localizing structures in each area are poorly defined (fig. C-8). Travertine ages in these areas range from essentially 0 to $>95 \mathrm{ka}$.

\section{Hydrogeologic Connections Between Mammoth and La Duke}

On the basis of chemical and isotopic studies, Kharaka and others (this volume) conclude that no more than a few percent Mammoth-type water is in La Duke Hot Spring, and that at present there is little or no evidence for a hydraulic connection. Even if the geochemical data imply that no thermal water from the Mammoth hydrothermal system flows to La Duke Hot Spring, the geologic structure is compatible with the presence of a hydrogeologic connection rather than a geological barrier between these areas, as discussed below.

Consideration of the geologic sections shown in figure C-8 indicate that Mammoth and La Duke may have hydrogeologic connections, particularly through permeable zones in the Mission Canyon Limestone in the Sepulcher structural low. For the Mammoth system, thermal waters may 
come from the Mission Canyon Limestone in the Sepulcher structural low (section CC) and migrate upward along the Mammoth or the Swan Lake fault (section EE') to feed the Mammoth system. Beneath Mammoth Hot Springs, the Mission Canyon Limestone is at a depth of about $0.5 \mathrm{~km}$, whereas in the Sepulcher structural low it is at a depth of about $1.5 \mathrm{~km}$ (section EE).

The La Duke system may also be fed through the Mission Canyon Limestone in the Sepulcher structural low (section CC'). There, thermal waters may flow northward down the gentle north dip of the Gardiner syncline to about $1.5 \mathrm{~km}$ below sea level at the synclinal axis and then move upward following the nearly vertical sedimentary layers and/or the Reese Creek fault system and emerge at La Duke Hot Spring. Flow may be constrained by Precambrian rocks forming the hanging wall of the Gardiner reverse fault and by lacustrine sediments within the glacial-scour basin (section $\mathrm{BB}$ ). In regard to potential geothermal development, if the pressure in the postulated Mission Canyon Limestone aquifer $3 \mathrm{~km}$ beneath La Duke Hot Spring were lowered, this pressure change might be transmitted beneath Sepulcher Mountain to the system feeding Mammoth Hot Springs.

Mammoth Hot Springs and La Duke Hot Spring occur on structures that may be connected at depth south of Bunsen Peak (fig. C-7), but hydrogeologic connections along these structures do not seem realistic because of the high temperatures involved. Mammoth Hot Springs occurs north along strike from the concentration of vents in the Norris-Mammoth corridor. La Duke Hot Spring occurs along the east Gallatin-Reese Creek fault system. South of Bunsen Peak, the inferred vertical fissures and dikes of the Norris-Mammoth corridor would intercept the east Gallatin fault (fig. C-7). For the corridor south of Bunsen Peak (fig. C-7), flow between the inferred dikes and fissures of the corridor and the east Gallatin fault is not likely because of the high temperatures indicated. The $1 \mathrm{ohm}-\mathrm{m}$ resistivities below $6-7 \mathrm{~km}$ suggest partial melt at temperatures of $500^{\circ}-600^{\circ} \mathrm{C}$ or higher (Stanley and others, this volume). The brittle-ductile transition for quartz at normal strain rates occurs in the $350^{\circ}-400^{\circ} \mathrm{C}$ range (Fournier, 1989). Below the brittle-ductile transition, open conduits for water flow would be sealed closed both by ductile rock flow and by precipitation of minerals as fluids move upward to cooler levels (Fournier, 1989). Fluid pressures below this zone of sealing would exceed hydrostatic and increase towards lithostatic reflecting the confinement and very restricted movement of fluids.

Such high temperatures at relatively shallow depths are not apparent north of Bunsen Peak, and neither are volcanic vents with inferred dikes and fissures. The chemistry of Mammoth, La Duke, and Sheepeater waters indicates that temperatures in reservoirs from which these waters are derived do not exceed $\sim 100^{\circ} \mathrm{C}$, whereas that for Norris and Clearwater waters is much hotter, about $300^{\circ} \mathrm{C}$ (Kharaka and others, this volume, table F-6).

\section{Hydrogeologic Connections Between Mammoth and the Gardiner Travertine Bench}

Although no hot water now emerges on the travertine bench above Gardiner, the extensive travertine deposits there indicate major hot springs in the past. The strontium-isotope ratios of the 
travertines on the travertine bench are similar to those of Mammoth waters, but they differ from those of La Duke Hot Spring and Bear Creek Springs (Kharaka and others, this volume). The ages of travertines from the Terrace Mountain-Mammoth area and the travertine bench appear to alternate in time, indicating the possibility that activity feeding each of these large systems may have alternated from one place to the other.

The travertine deposits on the Gardiner bench occur $55 \mathrm{~km}$ upvalley from the terminal moraines of the last glaciation and just inside the limits of a prominent recessional ice position (Deckard Flats readjustment of Pierce, 1973a; 1979). The sequence of travertine accumulation and glaciation is reconstructed for the travertine bench as follows: (1) travertine deposition about 55 $\mathrm{ka}$, (2) advance of the northern Yellowstone outlet glacier to a terminus $55 \mathrm{~km}$ downvalley and covering the travertine bench with about $640 \mathrm{~m}$ of ice; on the western margin of the Yellowstone ice sheet, this glacial culmination is dated as about $30-40 \mathrm{ka}$ by obsidian hydration methods (Pierce and others, 1976; Pierce, 1979), (3) major glacial recession to expose the travertine bench between 19 and $23 \mathrm{ka}$, but a glacial snout 200-300 m thick may have filled the Yellowstone valley below the level of the travertine bench, (4) glacial advance to the Deckard flats limit covering the dated travertine sites with 10-100 m of glacial ice; the Deckard Flats is older than 12 to $15 \mathrm{ka}$ on the basis of obsidian-hydration and carbon-14 dating elsewhere in Yellowstone (Pierce and others, 1976; Pierce, 1979), and (5) glacial recession from the area at about $12-15 \mathrm{ka}$, but with no travertine deposition from then until present.

Changes in hydrostatic pressures under partial glacial conditions could provide an explanation for a possible alternation of discharge between Mammoth Hot Springs and the travertine bench. Assuming that both systems connect to Mission Canyon Limestone in the asymmetric Gardiner syncline, several hundred meters of glacial ice on the Mammoth system but none on the travertine bench might change pressures and divert postulated flow from Mammoth through the Mission Canyon Limestone in the Gardiner syncline to the travertine bench. Although in Deckard Flats time, about $100 \mathrm{~m}$ of ice covered the Mammoth area and the travertine bench, at other times a glacial cover on Mammoth Hot Springs but not on the travertine bench appears possible given the observed phase differences between different source areas feeding the northern Yellowstone outlet glacier (Pierce, 1979, fig. 51). Filling the Yellowstone valley to the level of the travertine bench would increase hydrostatic head levels to near that of the travertine bench and thus help emergence of geothermal waters at heights of more than $300 \mathrm{~m}$ above the valley floor.

\section{Hydrogeologic Connections Between Mammoth and Bear Creek}

Chemical and isotopic evidence is consistent with a small ( $\sim 10$ percent) component of the water at Bear Creek Springs coming from the system that feeds Mammoth Hot Springs (Kharaka and others, this volume). The remainder might come from the north in the Beartooth uplift or more locally within the Gardiner fault and the northern limb of the Gardiner syncline. The moderate-sized travertine mounds at Bear Creek and across the Yellowstone River at Rattlesnake Butte mound suggest that thermal-water flows in the Bear Creek area were larger sometime between 10 and 15 
$\mathrm{ka}$ and around $57 \mathrm{ka}$, perhaps due to an increase in water flowing through carbonate aquifers in the Gardiner syncline that was related to elevated water tables existing at these times. Although the Gardiner syncline may provide a connection between the Mammoth and Bear Creek Springs, a postulated fault trending northeast from the Snow Pass area might also connect the two (figs. C-4 and C-8; Ruppel, 1972; U.S. Geological Survey, 1972). The paucity of exposures does not permit clear definition of such a fault, and most of the geophysical transects show no electrical evidence of a major structure where they cross this inferred fault in the area between identified faults near Snow Pass and the trace of the Lava Creek fault (Stanley and others, this volume, fig. D-4).

\section{References Cited}

Bargar, K.E., 1978, Geology and thermal history of Mammoth Hot Springs, Yellowstone National Park, Wyoming: U.S. Geological Survey Bulletin 1444, 55 p.

Barrientos, S.E., Stein, R.S., and Ward, S.N., 1987, Comparison of the 1959 Hebgen Lake, Montana and the 1983 Borah Peak, Idaho, earthquakes from geodetic observations: Bulletin of the Seismological Society of America, v. 77, p. 784-808.

Brown, C.W., 1961, Cenozoic stratigraphy and structural geology, northeast Yellowstone National Park, Wyoming and Montana: Geological Society of America Bulletin, v. 72, p. 1173-1194.

Bursik, M., and Sieh, K., 1989, Range front faulting and volcanism in the Mono Basin, eastern California: Journal of Geophysical Research, v. 94, p. 15,587-15,609.

Christiansen, R.L., 1984, Yellowstone magmatic evolution: its bearing on understanding largevolume explosive volcanism in Explosive volcanism: inception, evolution, and hazards: National Academy Press, Studies in Geophysics, p. 84-95.

Christiansen, R.L., and Blank, H.R., 1972, Volcanic stratigraphy of the Quaternary rhyolite plateau in Yellowstone National Park: U.S. Geological Survey Professional Paper 729B, 18 p.

Downey, J.S., 1984, Geohydrology of the Madison and associated aquifers in parts of Montana, North Dakota, South Dakota, and Wyoming: US. Geological Survey Professional Paper 1273G, 47 p.

Eaton, G.P., Christiansen, R.L., Iyer, H.M., Pitt, A.M., Mabey, D.R., Blank, H.R., Jr., Zeitz, Isidore, and Gettings, M.E., 1975, Magma beneath Yellowstone National Park: Science, v. 188, p. 787-796.

Foose, R.M., Wise, D.U., and Garbarini, G.S., 1961, Structural geology of the Beartooth Mountains, Montana and Wyoming: Geological Society of America Bulletin., v. 72, p. 1143-1172.

Fournier, R.O., 1989, Geochemistry and dynamics of the Yellowstone National Park hydrothermal system: Annual Review of Earth and Planetary Sciences, v. 17, p. 13-53.

Fraser, G.D., Waldrop, H.A., and Hyden, H. J., 1969, Geology of the Gardiner area, Park County, Montana: U.S. Geological Survey Bulletin 1277, 118 p.

Goldstein, S.J., Murrell, M.T., and Janeckey, D.R., 1989, Th and U isotopic systematics of basalts from the Juan de Fuca and Gorda Ridges by mass spectrometry: Earth and Planetary Science Letters, v. 96, p. 134-146.

Hildreth, W., 1981, Gradients in silicic magma chambers: Implications for lithospheric magmatism: Journal of Geophysical Research, v. 86, p. 10,153-10,192. 
Hydrometrics, 1986, Aquifer testing and evaluation of a geothermal well at Royal Teton Ranch near Corwin Springs, Montana: Hydrometrics, 2727 Airport Road, Helena, Montana, 15p., plus 5 appendices, unpublished.

$\mathrm{Ku}$, T.L., and Liang, Z.C., 1984, The dating of impure carbonates with decay-series isotopes: Nuclear Instruments and Methods in Physics Research, v. 223, p. 563-571.

Love, J.D., and Keefer, W.R., 1975, Geology of sedimentary rocks in southern Yellowstone National Park, Wyoming: U.S. Geological Survey Professional Paper 729-D, 60 p.

Patterson, W.S.B., 1981, The Physics of Glaciers: Pergamon Press, Oxford, 380 p.

Pierce, K.L., 1973a, Surficial geologic map of the Mammoth Quadrangle and part of the Gardiner Quadrangle, Yellowstone National Park, Wyoming and Montana: U.S. Geological Survey Miscellaneous Geologic Investigations Map I-641, scale 1:62,500.

Pierce, K.L., 1973b, Surficial geologic map of the Mount Holmes quadrangle and parts of the Teepee Creek, Crown Butte, and Miner quadrangles, Yellowstone National Park, Wyoming and Montana: U.S. Geological Survey Miscellaneous Geologic Investigations Map I-640, scale $1: 62,500$.

Pierce, K.L., 1979, History and dynamics of glaciation in the northern Yellowstone National Park area: U.S. Geological Survey Professional Paper 729F, 90 p.

Pierce, K.L., Obradovich, J.D., and Friedman, I., 1976, Obsidian-hydration dating and correlation of Bull lake and Pinedale Glaciations near West Yellowstone, Montana: Geological Society of America Bulletin, v. 87, p. 703-710.

Porter, S.C., Pierce, K.L., and Hamilton, T.D., 1983, Late Pleistocene glaciation in the Western United States, in H.E. Wright, ed., Late Quaternary Environments of the United States: Minneapolis, Minn., University of Minnesota Press, p. 71-111.

Reilinger, R.E., Citron, G.P., and Brown, L.D., 1977, Recent vertical crustal movements from precise leveling data in southwestern Montana, western Yellowstone National Park and the Snake River Plain: Journal of Geophysical Research, v. 82, p. 5349-5359.

Richmond, G.M., and Fullerton, D.S., 1986, Introduction to Quaternary Glaciations in the United States of America in Quaternary Glaciations in the Northern Hemisphere, Sibrava, V., Bowen, D.Q., and Richmond, G.M., editors: Quaternary Science Reviews, v. 5, p. 3-10.

Ruppel, E.T., 1972, Geology of pre-Tertiary rocks in the northern part of Yellowstone National Park, Wyoming: U.S. Geological Survey Professional Paper 729-A, 66 p.

Smith and Braile, 1984, Crustal Structure and evolution of an explosive silicic volcanic system at Yellowstone National Park, Explosive volcanism: inception, evolution, and hazards: National Academy Press, Studies in Geophysics, p. 84-95.

Struhsacker, E.M., 1976, Geothermal systems of the Corwin Springs-Gardiner area, Montana; possible structural and lithologic controls: Unpublished Master of Science thesis, Montana State University, Bozeman, Montana, 93 p.

U.S. Geological Survey, 1972, Geologic map of Yellowstone National Park: U.S. Geological Survey Miscellaneous Geologic Investigations Map I-711, scale 1:125,000.

White, D.E., Hutchinson, R.A., and Keith, T.E.C., 1988, The geology and remarkable thermal activity of Norris Geyser Basin, Yellowstone National Park, Wyoming: U.S. Geological Survey Professional Paper 1456, 84 p.

Wilson, C.W., Jr., 1934, Geology of the thrust fault near Gardiner, Montana: Journal of Geology, v. 42 , p. $649-663$. 


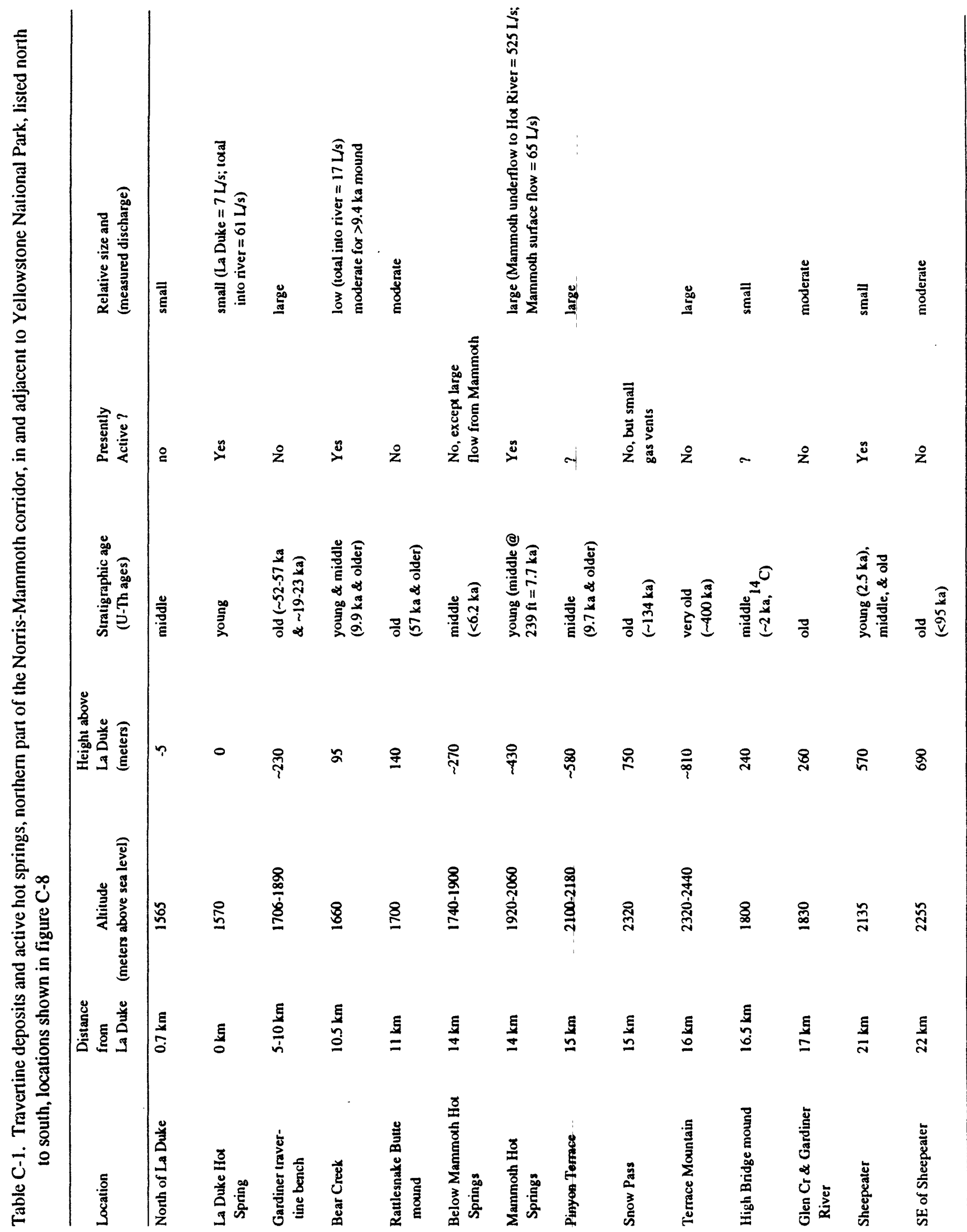




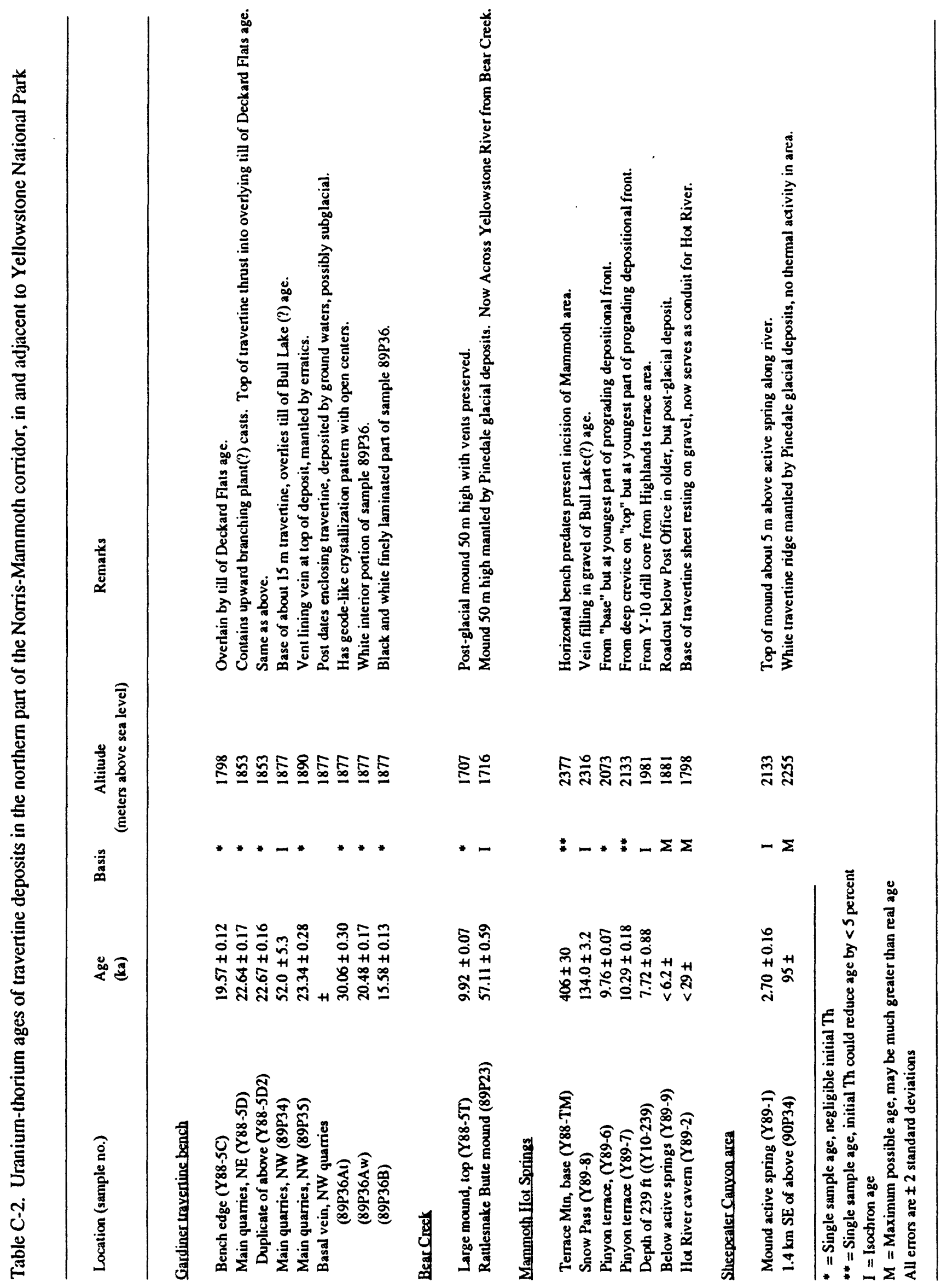




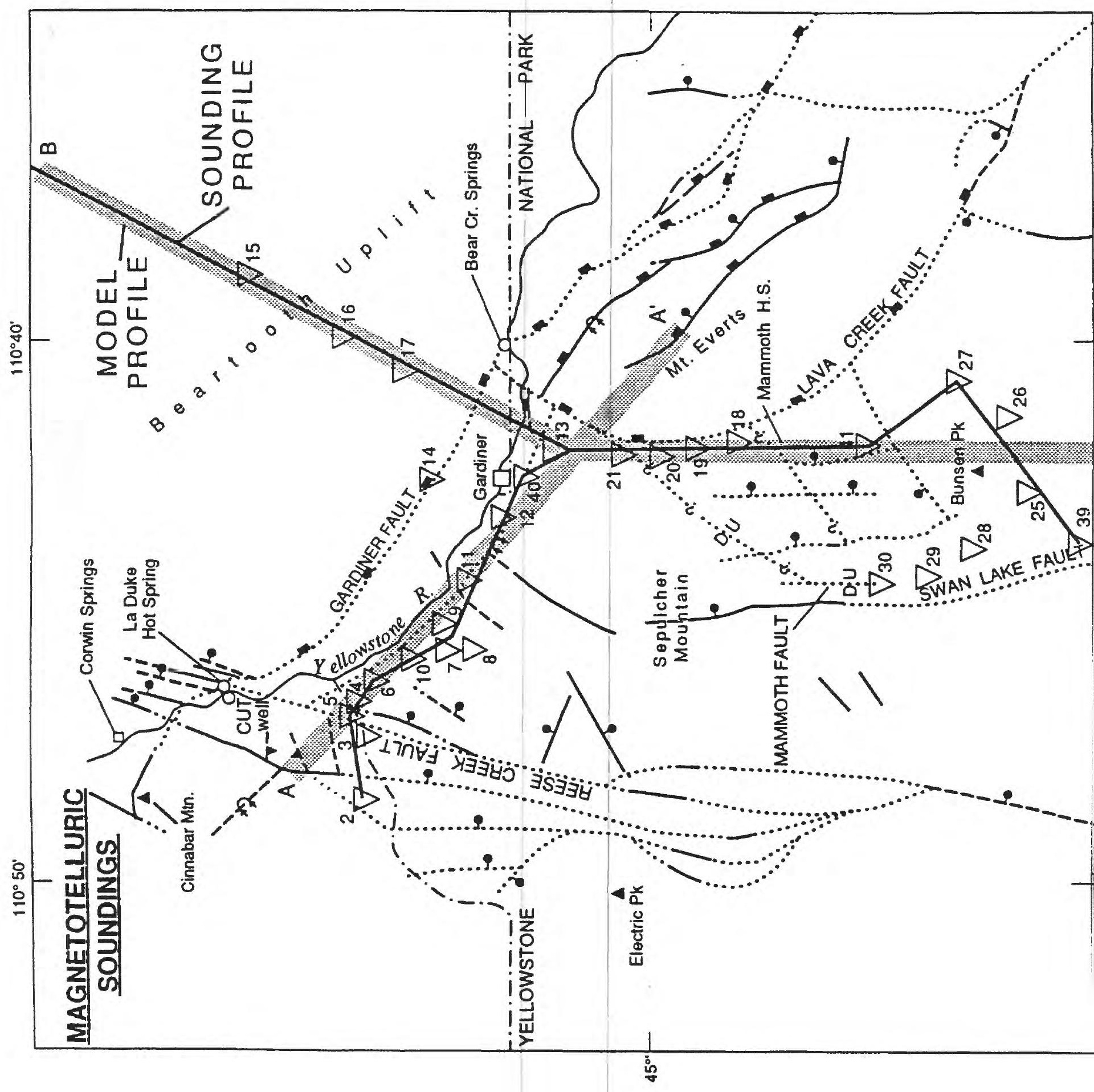




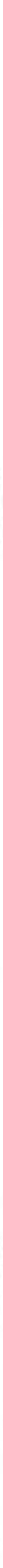




\section{EXPLANATION}

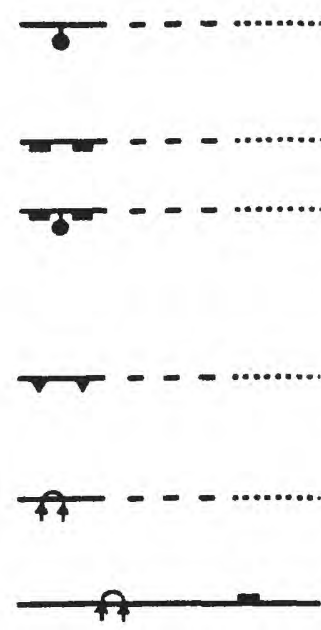

- - U - - D - - Fa

${ }^{40}$

Normal fault--Dashed where inferred; dotted where concealed; queried where uncertain. Bar and ball on downthrown side.

Reverse fault--Dashed where inferred; dotted where concealed

Reverse fault along which later normal faulting took place--Dashed where inferred; dotted where concealed. Block teeth on overriding block. Bar and ball on downthrown side.

Thrust fault--Dashed where inferred; dotted where concealed. Sawteeth on overriding plate.

Axis of asymmetrical, overtumed syncline--Dashed where inferred; dotted where concealed.

Axis of asymmetrical, overtumed syncline with known or inferred reverse fault

Fault with unknown dip--queried where doubtful. Sense of displacement indicated by $D$ (down) and $U$ (up).

Magnetotelluric sounding projected onto model profiles $\mathrm{AA}^{\prime}$ and $\mathrm{BB}^{\prime}$.

Figure D-1. Locations of magnetotelluric (MT) soundings, interpreted model profiles $\mathrm{AA}^{\prime}$ and $\mathrm{BB}^{\prime}$, and geologic structures in the Norris-Mammoth-La Duke study area. Data from the MT soundings were projected on to the model profiles. 
conditions of the rocks can frequently be interpreted from MT data. The locations of MT soundings done in the Norris-Mammoth corridor are shown in figure D-1. The MT data were recorded as resistivities and associated phase values as a function of frequency from $0.005 \mathrm{~Hz}$ to $250 \mathrm{~Hz}$. Instrumentation for the surveys consisted of sensors for measurement of the earth's natural magnetic and electric fields, filter banks and other signal conditioning, and a computer-controlled dataacquisition system that processes the data in real time during acquisition of the signals. The recorded magnetic and electrical signals are processed digitally to compute earth resistivities as indicated in the example sounding data of figure D-2. The two distinct resistivity curves represent processed data that have been mathematically rotated to maximum and minimum resistivity directions, which normally correspond to the strike and dip directions of the most prominent geologic structure. The phase of the resistivity and a factor which indicates three-dimensionality in the data are also computed and may be used in the interpretation. Computer modeling involves construction of earth models in one, two, or three-dimensional geometries to simulate the observed data.

On the basis of well-logs from the Yellowstone region and from the MT soundings in the study area, the following correlation of resistivity with lithology is generally assumed in our interpretation of the MT data:

1. Quaternary alluvium and glacial materials: $10-30 \mathrm{ohm}-\mathrm{m}$

2. unaltered Quaternary volcanic rocks: $>100 \mathrm{ohm}-\mathrm{m}$

3. altered Quaternary rocks: $2-20 \mathrm{ohm}-\mathrm{m}$

4. Tertiary volcanic rocks: $10-30 \mathrm{ohm}-\mathrm{m}$

5. Cretaceous and older shales: $3-20 \mathrm{ohm}-\mathrm{m}$

6. Jurassic-Ordovician sandstones and carbonates: $100-300 \mathrm{ohm}-\mathrm{m}$

7. intrusive rocks: $1,000-10,000 \mathrm{ohm}-\mathrm{m}$

8. Precambrian gneiss and granite: $>1,000 \mathrm{ohm}-\mathrm{m}$

9. Precambrian graphitic schist: $1-5 \mathrm{ohm}-\mathrm{m}$

10. partial melt and fluids in the midcrust: $1-3 \mathrm{ohm}-\mathrm{m}$

There is, of course, overlap in resistivities between Quaternary alluvium, glacial drift, altered volcanic rocks, and Cretaceous shales for the upper parts of the geologic section. Graphitic schists that occur in the area north of Gardiner, Montana, may be very conductive and overlap the resistivity values of magma and hot, fluid-rich zones.

Data from the $40 \mathrm{MT}$ soundings completed in the corridor region were projected on to two model profiles, $\mathrm{AA}^{\prime}$ and $\mathrm{BB}^{\prime}$ (fig. $\mathrm{D}-1$ ) that were interpreted with two-dimensional computer models. $\mathrm{BB}^{\prime}$ is the north end of a regional profile that extends completely across the caldera. The use of two-dimensional models was not completely adequate because the geology is highly threedimensional. These two MT profiles were completed parallel to the strike of some key structural features. For instance, profile $\mathrm{AA}^{\prime}$ parallels the Gardiner reverse fault and Beartooth uplift and both these structures affect the sounding data. Also, profile $\mathrm{BB}^{\prime}$ parallels the strike of the NorrisMammoth corridor. The two profiles do cross some important features, such as the Reese Creek fault and the Gardiner reverse fault, orthogonally. The most rigorous application of MT method to the area would involve a two-dimensional array of measurement points and three-dimensional 


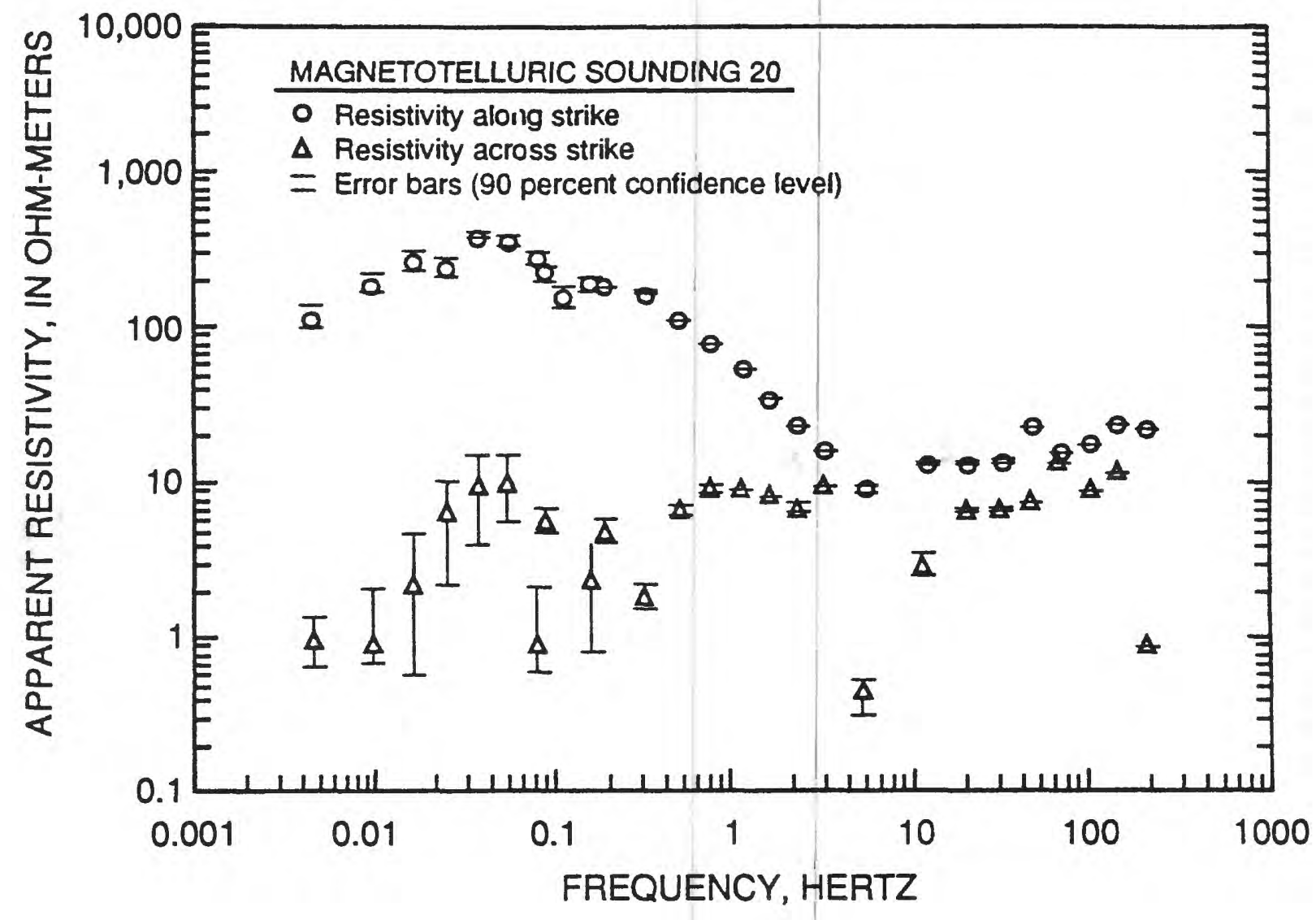

Figure D-2. Example magnetotelluric sounding from location 20; resistivity in the two rotated principal direction (along strike and across strike) are shown by the circles and the triangles, along with error bars determined from data statistics. 
modelling of the data set. A two-dimensional array of sounding data adequate to sample the complex geologic structures could not be obtained because of restriction of the MT system deployment to roads. Instead, the sounding data was projected onto one of two model sections for which two-dimensional computations of resistivity were done.

The 2D model for profile $\mathrm{AA}^{\prime}$ is depicted in upper part of figure D-3 for the upper 3-km section of the model. The 10-30 ohm-m units that range in thickness from $200 \mathrm{~m}$ to $1,500 \mathrm{~m}$ between soundings 6 and 12 on profile $\mathrm{AA}^{\prime}$ are probably largely alluvium and Cretaceous shales, with the latter normally having resistivities of $3-20 \mathrm{ohm}-\mathrm{m}$. The sharp decrease in thickness of this $10-30 \mathrm{ohm}-\mathrm{m}$ section between at soundings 12 and 13 on profile $\mathrm{AA}^{\prime}$ occurs near the intersection of the Mount Everts block and the Gardiner reverse fault. Units of $100-300 \mathrm{ohm}-\mathrm{m}$ in the $\mathrm{AA}^{\prime}$ model may represent Triassic to Mississippian carbonates and sandstones and 1,000-10,000 ohm-m units are interpreted correspond to Tertiary intrusives and Precambrian crystalline rocks.

The vertical low-resistivity ( $1 \mathrm{ohm}-\mathrm{m}$ ) features beneath soundings 6,11 , and 21 are required to fit the sounding data in a two-dimensional sense, but resolution on the dip, depth extent and actual resistivity of these features is poor because of their limited horizontal extent. The vertical conductive feature near sounding 6 may represent intense hydrothermal alteration along the Reese Creek fault. Other explanations for the low resistivity of this feature, such as water in brecciated zones or dissolved carbonates would not produce the low resistivities required. Hydrothermal alteration along the Reese Creek fault could be related to thermal-water flow in the circulation system supplying La Duke Hot Spring. The contrast in resistivity across this fault (30-100 ohm-m on the west; $1-10 \mathrm{ohm}-\mathrm{m}$ on the east) is evident in both the MT model and on the data from telluric traverse line 1 (figs. D-4 and D-5). It should be noted, however, that at the telluric measurement frequencies $(7.5-14,000 \mathrm{~Hz})$, the telluric data are being influenced mostly by the upper $500 \mathrm{~m}$ of the section.

Interpreted vertical conductive features near MT soundings 11 and 21 may be associated with other alteration zones that are also indicated in telluric traverse lines (fig. D-4). These features are here designated the Landslide Creek and Lava Creek faults. Geological evidence for the Lava Creek fault is discussed by Pierce and others (this volume). For the Landslide Creek fault, there is no corresponding geologic evidence, except for a short fault segment along trend, north of the Yellowstone River, that displaces Cretaceous beds (fig. C-1). The available evidence does not allow us determine whether these structures are connected to, or related in some way, to northwardtrending faults identified in the Mammoth Hot Springs area. It is possible that hydrothermal alteration along the Landslide Creek fault was associated with thermal-water flow to the Gardiner bench, where extensive travertine deposits evidence significant hot-spring discharge prior to the last glacial recession (Pierce and others, this volume). Similarly, the zone of low resistivity along the Lava Creek fault could result from thermal-water flow associated with Bear Creek Springs and/or travertine deposits across the Yellowstone River from Bear Creek at Rattlesnake mound (Pierce and others, this volume).

The actual dip of geological structures across profile $\mathrm{AA}^{\prime}$ is difficult to assess from the MT models. Cretaceous units and alluvium (10-30 ohm-m) are relatively uniform in thickness (about $500-1,000 \mathrm{~m}$ ), but the thickness of $100-300 \mathrm{ohm}-\mathrm{m}$ units representing Triassic to Mississippian 

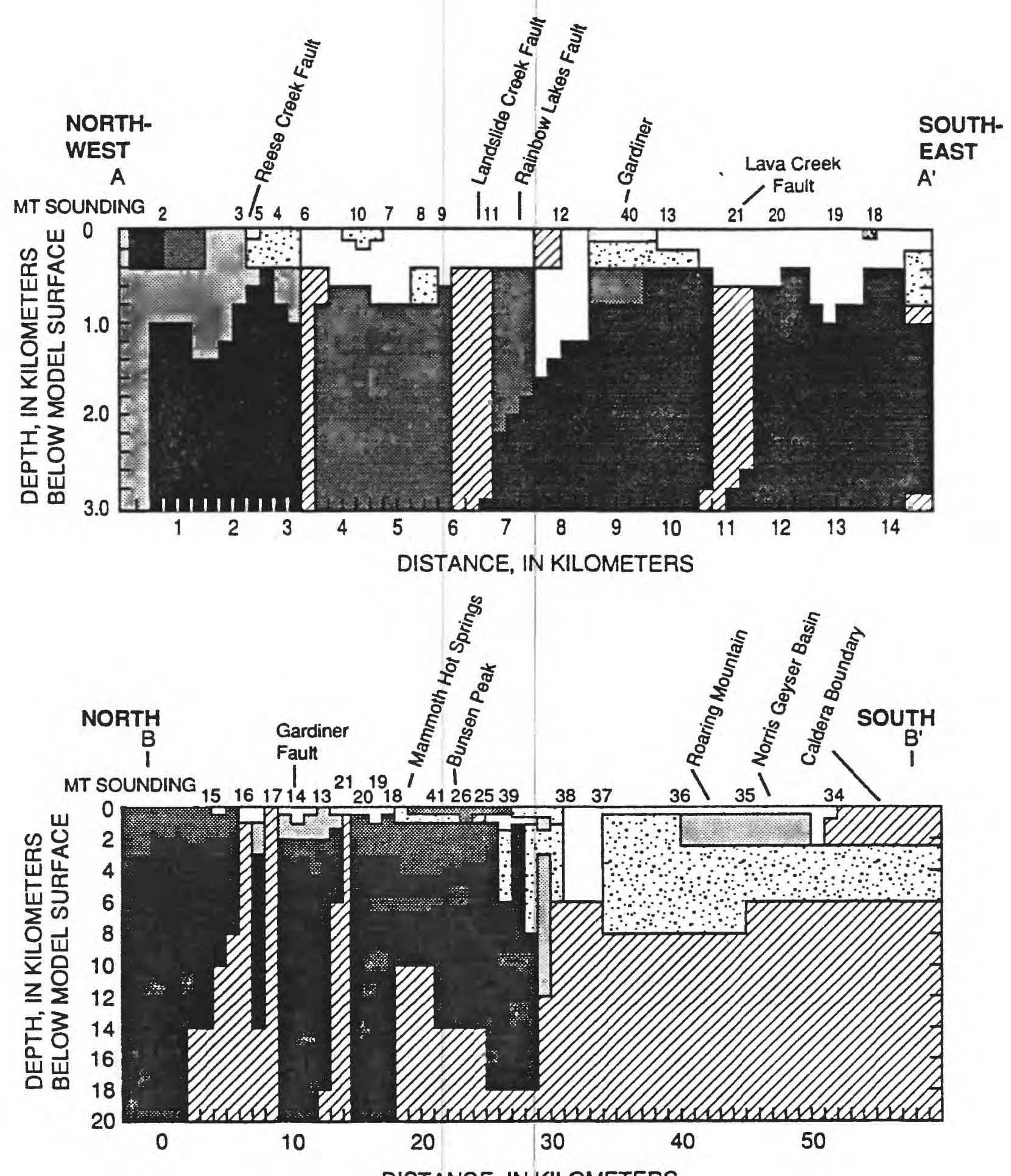

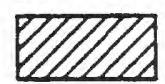

1

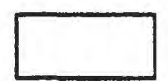

10

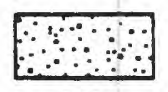

30

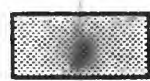

100

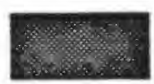

300

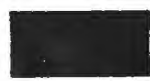

1000

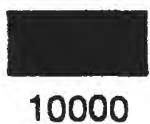

\section{RESISTIVITY, IN OHM-METERS}

Figure D-3. Detailed two-dimensional models for magnetotelluric (MT) profiles $\mathrm{AA}^{\prime}$ (top) and BB' (bottom). Section locations and labeled features shown in figures D-1. Model computations extended to over $40 \mathrm{~km}$ depth, but only the upper $3 \mathrm{~km}$ is shown for $\mathrm{AA}^{\prime}$ and the upper 20 $\mathrm{km}$ for $\mathrm{BB}^{\prime}$. Locations of MT soundings were projected on to the corresponding model profile. 


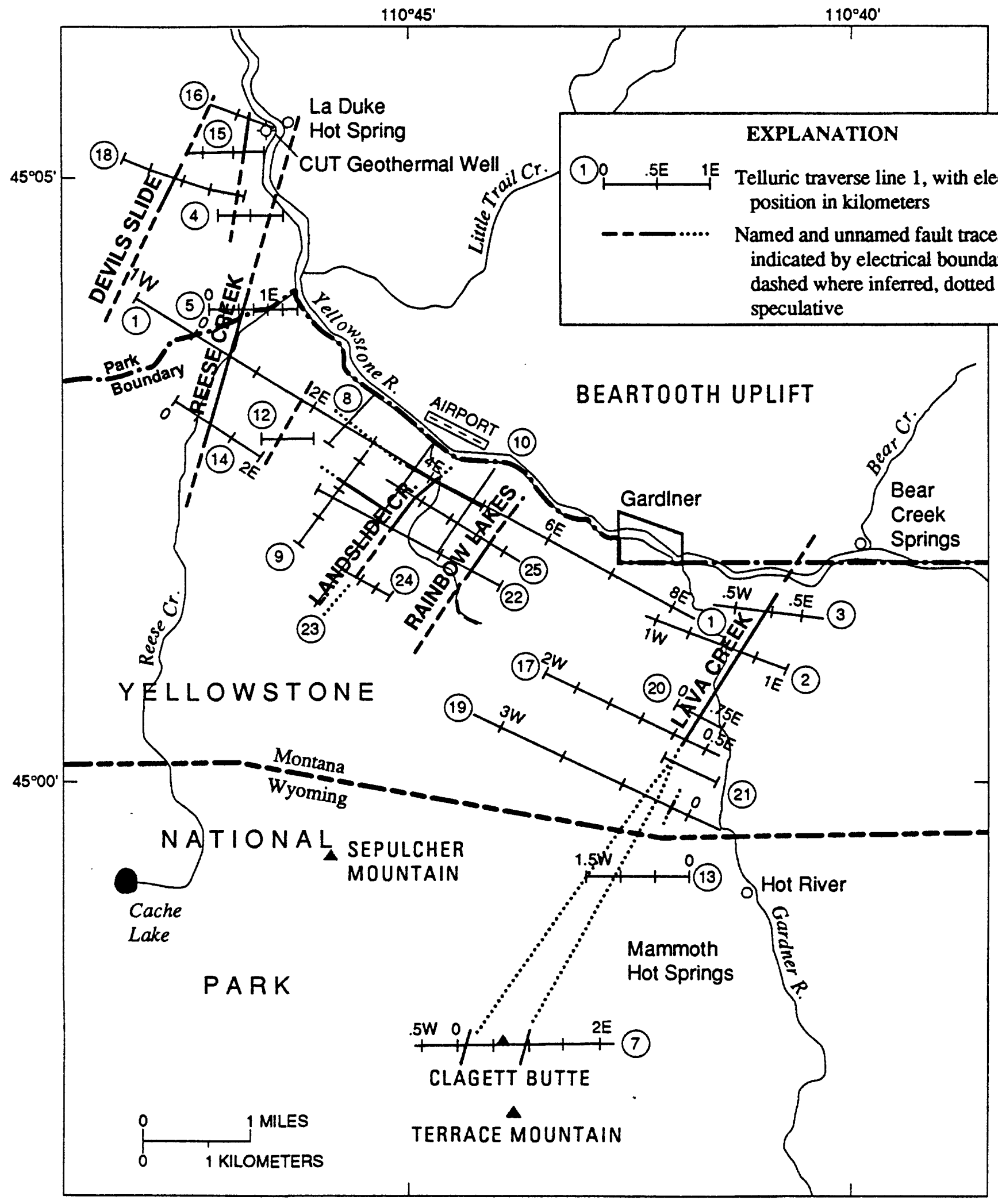

Figure D-4. Locations of telluric traverse lines and faults inferred from the telluric data and geologic mapping. 


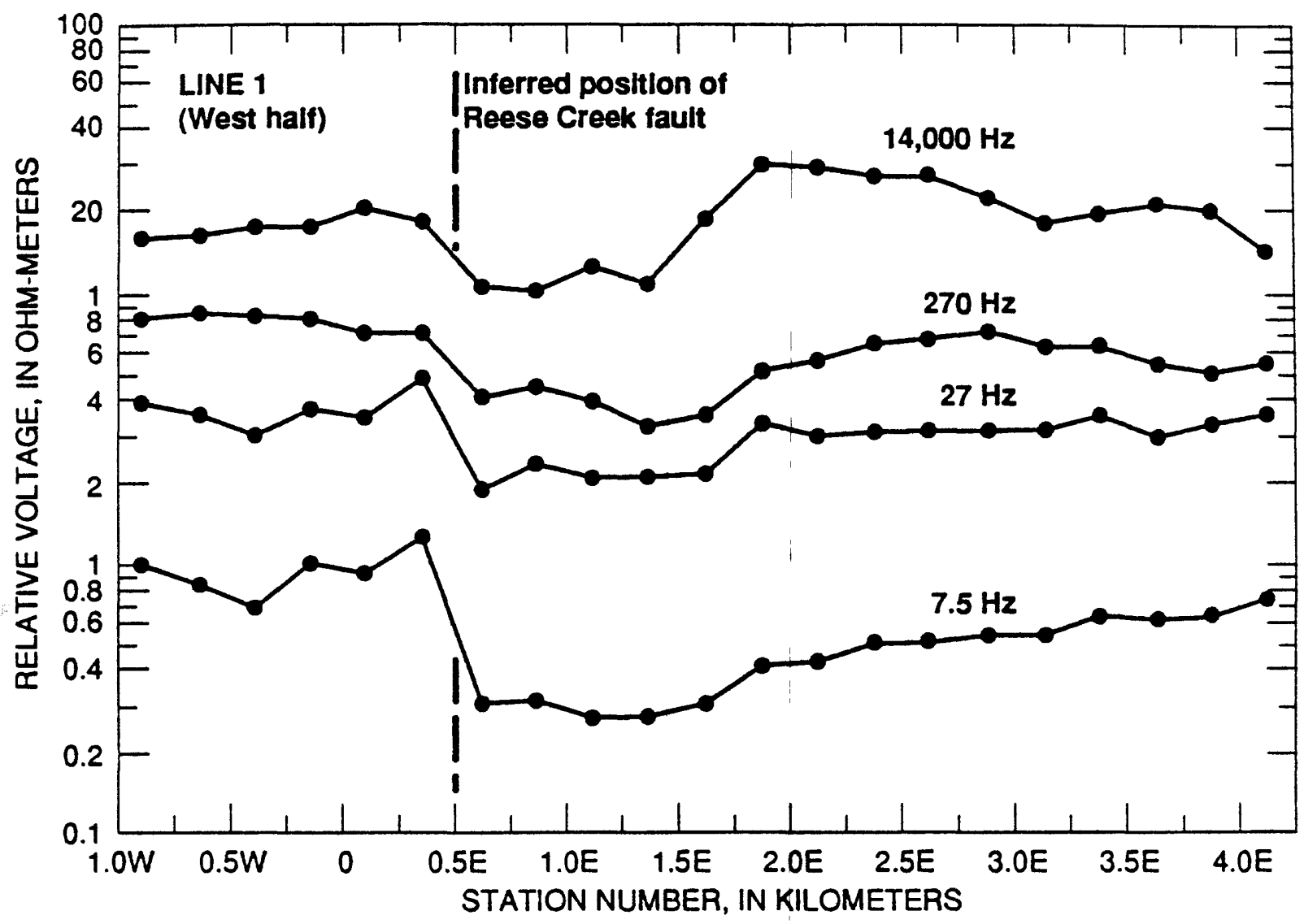

Figure D-5. Multifrequency telluric voltage data for the western part of traverse 1 showing the electrical response observed across the Reese Creek fault. 
carbonates is poorly resolved in the model for profile $\mathrm{AA}^{\prime}$ because of their intermediate resistivity values.

The $\mathrm{BB}^{\prime}$ model is shown to a depth of $20 \mathrm{~km}$ in the lower part of figure D-3 and indicates high resistivities north of sounding 39, possibly related to Precambrian basement and Tertiary intrusive bodies like those mapped at Electric Peak and Bunsen Peak (Pierce and others, this volume). The area near Mammoth Hot Springs is characterized by $1-30 \mathrm{ohm}-\mathrm{m}$ rocks in the upper $1 \mathrm{~km}$, although limited access and numerous powerlines prevented us from obtaining more detailed information about the precise electrical structure there. A significant change in overall electrical structure occurs near sounding 39 . South of sounding 39 , resistivities down to $8 \mathrm{~km}$ are only $1-30$ ohm-m. This conductive upper crustal section may represent broad, intense alteration caused by geothermal activity associated with the main Yellowstone caldera system.

Intense alteration within the caldera proper, as indicated at sounding 34, produces resistivities of about $1 \mathrm{ohm}-\mathrm{m}$ in the upper $1-2 \mathrm{~km}$. The resistivities of $100 \mathrm{ohm}-\mathrm{m}$ at $0.5-2.0 \mathrm{~km}$ depth beneath soundings 35 and 36 (near Roaring Mountain and Norris Geyser Basin) may correspond to steam zones in the thermal reservoir beneath this area of hydrothermal vents.

The $1 \mathrm{ohm}-\mathrm{m}$ section that occurs at depths greater than about $6-7 \mathrm{~km}$ south of sounding 39 is interpreted to represent a zone of partial melt, metamorphic fluids, and magma. This zone becomes even shallower (less than $5 \mathrm{~km}$ ) inside the Yellowstone caldera where the inference of temperatures compatible with partial melt is corroborated by seismicity data (Smith and others, 1974). Temperatures in this zone are expected to be $500^{\circ}-600^{\circ} \mathrm{C}$ or higher (Stanley and others, 1977). The model structure involving $1 \mathrm{ohm}-\mathrm{m}$ material at a depth of $10 \mathrm{~km}$ between soundings 18 and 41 in the Mammoth area is poorly constrained because of lack of sounding points, and it is difficult to assess if this conductor could be related to a separate magma system associated with Mammoth Hot Springs. Low-resistivity units beneath the Gardiner reverse fault (soundings 15 and 17) are likely related to graphitic schists that occur in Precambrian metamorphic rocks in this area and are probably not related to the same mechanism causing low resistivities south of sounding 39 .

\section{Telluric Data}

The telluric, or natural-source, electromagnetic method provides electrical resistivity information in areas where access is difficult or where restrictions on truck-mounted equipment preclude practical acquisition of other types of electrical data (such as MT soundings). Problems of access in the area were important in selection of the telluric method for this study. The telluric method uses naturally occurring electromagnetic fields to measure changes in earth resistivity along a linear traverse. Because the penetration of the electromagnetic energy varies with frequency, with lower frequencies penetrating to greater depths, measurements made at several frequencies will provide information at varying depth. However, the effective depth of penetration is not only a function of frequency, but also of earth resistivity (Keller and Frischknecht, 1966; Beyer, 1977). In this study, frequencies of $7.5,27,270$ and $14,000 \mathrm{~Hz}$ were used. At the highest frequency used, the data show variations from the surface to a depth range of 10 to 30 meters, and at $7.5 \mathrm{~Hz}$ the maximum penetration is about 5001200 meters for resistivities of 7-30 ohm-m, typical values for the study area. The electromagnetic energy in this frequency range is derived from distant lightning storms. 
A telluric traverse shows changes in electrical resistivity along the traverse by changes in the relative value of the natural electromagnetic potential measured at the earth's surface along segments of the traverse. The electrical potential change is proportional to the square root of the change in resistivity (Beyer, 1977). Because earth resistivities can change by over 4 orders of magnitude $(<1$ $\mathrm{ohm}-\mathrm{m}$ for saline clays to $30,000 \mathrm{ohm}-\mathrm{m}$ or more for unaltered intrusive rocks), electrical methods provide a means of discriminating between lithologies. Where faulting has juxtaposed lithologies of differing resistivities, telluric traverses can be effective in identifying such structures even below cover rocks. Because of the disruption and fracturing of rock along a fault, a zone of increased permeability is often created that can be reflected as a zone of lower resistivity. Even where the fault cuts similar lithologies, the fracture zone may often be identified in electrical data by its lower resistivity. Such effects were seen in the telluric traverse data obtained in the northern part of the study area and used, with geologic data, to infer structures.

The potential measurements are made along equally spaced segments of the traverse called dipoles. In this study dipoles were normally $250 \mathrm{~m}$ long, but a few traverses used 125 or $50 \mathrm{~m}$ dipoles in order to provide greater detail. The $250 \mathrm{~m}$ dipole is a compromise between resolution of lateral structures and speed in data acquisition. Figure D-4 shows the location of all telluric traverses made in the corridor. Selected electrode positions are indicated on each line, along with the starting point at position 0 . Distances along each line are given in kilometers east or west of position zero.

Data from traverses crossing important structures are discussed below, and interpretations based on the electrical data and known geology are shown in figure D-4. Traverse line 1 crosses the north boundary area from west of Reese Creek to the Gardner River. Figure D-5 shows the western part of traverse line 1 which crosses the Reese Creek fault. The inferred position of the fault (figs. C-1 and D-4) crosses the traverse just west of position $0.5 \mathrm{E}$ on this line. Note that the relative telluric voltage values are plotted on a logarithmic scale, and that each data point is plotted at the midpoint between electrode positions because the measured voltage is averaged over the dipole length; $250 \mathrm{~m}$ in this case. Also, traverse data for each frequency are offset vertically an arbitrary amount to prevent crossing over of the curves. The electrical signature of the Reese Creek fault is clearly seen crossing position $0.5 \mathrm{E}$ as a change from high values (high resistivities) to low values (low resistivities) at this position. At the lowest frequency $(7.5 \mathrm{~Hz})$, the resistivity contrast is greater than at the higher frequencies, indicating that the resistivity contrast between the deeper units is greater than between units near the land surface. The approximately 3:1 voltage contrast indicates that the resistivity contrast is about 10:1. This is consistent with modeling of MT sounding data near this contact which suggests a 3:1 contrast to a depth of $400 \mathrm{~m}$, then increasing to $100: 1$ at greater depth.

The $14,000 \mathrm{~Hz}$ data for traverse line 1 (fig. D-5) show a zone of lower resistivity from position $0.5 \mathrm{E}$ to $1.5 \mathrm{E} \mathrm{m}$ that correlates with outcrops of late Cretaceous Landslide Creek Formation sedimentary rocks. Both east and west of this low resistivity zone the traverse is on Quaternary alluvium and glacial deposits that appear as higher resistivity units. Traverse line 14 (figure D-4) crosses the Reese Creek fault about 3/4 mile south of traverse line 1, and shows a very similar telluric response (not shown). The telluric data suggest that the fault is several hundred meters east of the Reese Creek drainage along which it is inferred on the geologic map (see figs. C-1 and D-4). 
Figure D-6 shows telluric data for traverse line 5, which crosses the Reese Creek fault where the Quaternary cover is thick. On this traverse the two higher-frequency curves show relatively little change, indicating that the electromagnetic energy is not reaching through the covering Quaternary deposits. However, the $7.5 \mathrm{~Hz}$ traverse data show a resistivity step decreasing to the east at station $0.5 \mathrm{E}$ indicative of the Reese Creek fault. A low value between stations $0.5 \mathrm{E}$ and $0.75 \mathrm{E}$ at $27 \mathrm{~Hz}$ also suggests that increased fracturing related to the faulting is seen on this dipole.

To better define the fault position on this line, the traverse was repeated from position $0.45 \mathrm{E}$ to $0.75 \mathrm{E}$ in $50 \mathrm{~m}$ intervals. On this detailed line (data not shown), the fault is interpreted to cross in the $0.6 \mathrm{E}$ to $0.65 \mathrm{E}$ interval. Traverse 4 crosses the northern extension of the Reese Creek fault as defined by telluric lines $1,5,6$, and 14 . The data for line 4 are very noisy due to power lines in the Royal Teton Ranch area. However, an abrupt drop in resistivity is seen on the easternmost dipole, consistent with a linear extrapolation of the Reese Creek fault. A straight-line extension of this trend to the north places the Reese Creek fault about $300 \mathrm{~m}$ east of $\mathrm{La}$ Duke Hot Spring and coincident with faulting mapped in Precambrian and Tertiary units on the north side of the Yellowstone River (fig. C-1).

The Lava Creek fault (fig. D-4 and Pierce and others, this volume) had been inferred to cross the flat-lying plateau southeast of the confluence of the Gardner and Yellowstone Rivers with a southwest strike, but its exact position was poorly constrained on the geologic map (fig. C-1). Traverse lines $2,3,17,19,20$, and 21 were run to help constrain the position of this fault east of the Gardner River, and to determine its position west of the river. Figure D-6 shows data from lines 2,3 , and 20 defining an abrupt resistivity contrast that we infer is the Lava Creek fault. Resistivities are low on the west side of the fault, and high on the east as seen at the lower frequencies. The fault trace is approximately at positions $0.25 \mathrm{E}, 0$, and $0.375 \mathrm{E}$ on traverses 2,3 , and 20, respectively, in agreement with its inferred position on the geologic map (fig. C-1). At the position of the fault trace on all three lines, Quaternary deposits crop out and conceal its presence. The lack of response on the shallow-looking $14,000 \mathrm{~Hz}$ data also shows that faulting is not reflected in the electrical properties of the cover. The drop in resistivity seen in the high frequencies at the east end of line 3 is related to the faulted axis of the Gardiner syncline crossing obliquely to the line at position $0.6 \mathrm{E}$ (fig. C-1)

The $14,000 \mathrm{~Hz}$ data for traverse lines 2 and 20 show abrupt changes at positions $0.75 \mathrm{~W}$ and $0.125 \mathrm{E}$, respectively, with low resistivities to the west. An outcrop of Cretaceous Landslide Creek Formation exists between these two positions. Similar to the observation on line 1, the low resistivities may be reflecting the contact with the Landslide Creek sediments where they are covered by very thin Quaternary deposits.

The Lava Creek fault extends southwestward along strike to traverse 17 where a similar telluric response is seen, but somewhat reduced in amplitude. If this structure extends farther to the southwest to Clagett Butte (fig. D-4), it conceivably could coincide with the northeast-trending branch of the Mammoth fault postulated by Ruppel (1972). The electrical data alone do not identify such an extension. Evidence of faulting near Clagett Butte in the telluric data is discussed below. Line 19 , south of line 17 , shows an abrupt 10:1 resistivity change across position $0.25 \mathrm{E}$, with lower resistivities to the east. Similar features are not seen on adjacent lines (21 and 13). If the contrast is related to faulting, we are unable to constrain the strike of this feature. The possible southward 


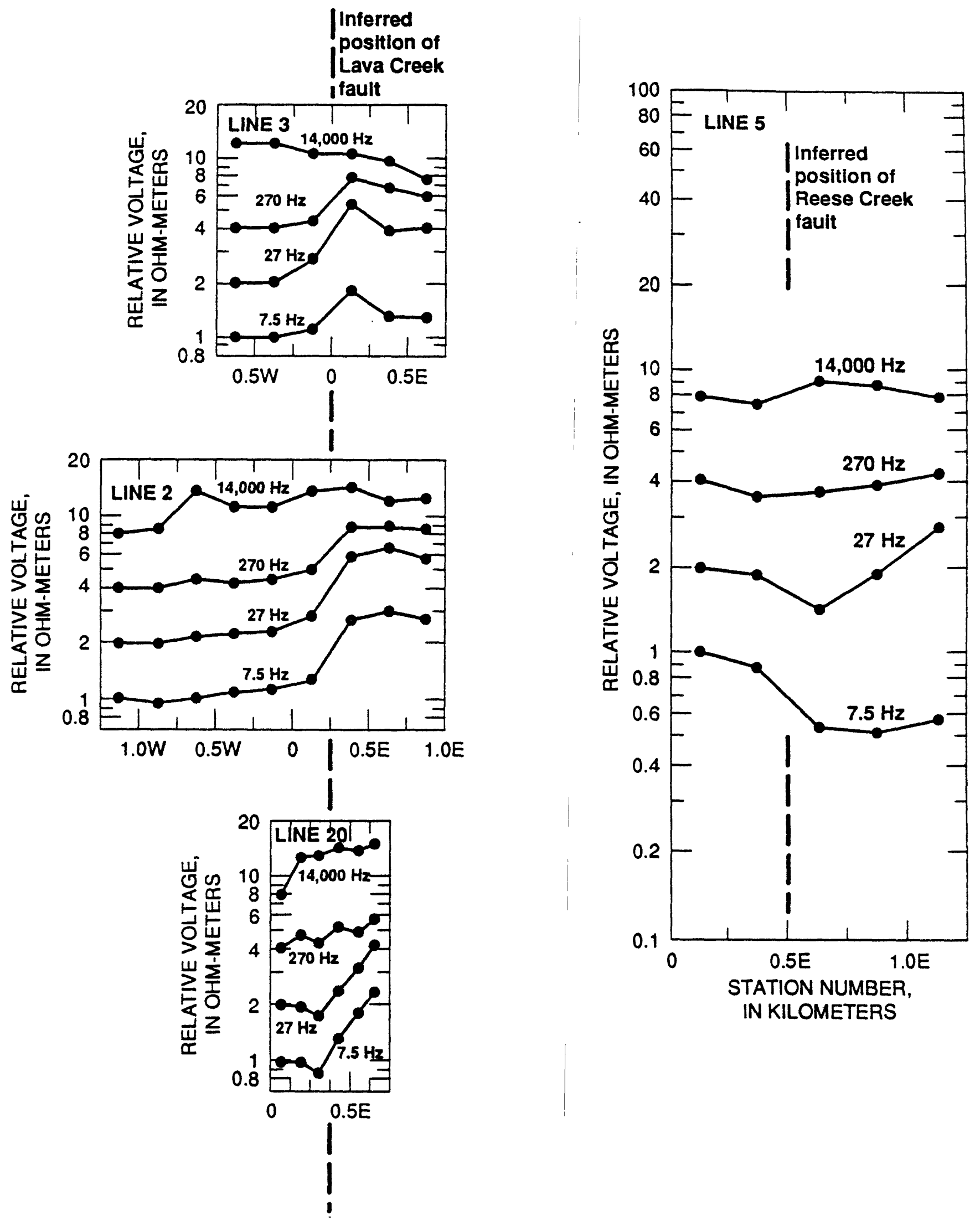

Figure D-6. Multifrequency telluric voltage data for traverse lines 2, 3, and 20 showing the electrical response observed across the Lava Creek fault (left) and traverse line 5 across the Reese Creek fault (right). 
bend in the trend of this feature between traverse lines 17 and 19 is consistent with the position of the Lava Creek reverse fault in this area (fig. C-1), inferred from outcrops of Cretaceous rocks near the 45th parallel.

Farther to the southwest, two faults inferred from telluric line 7 across Clagett Butte (figs. D-4 and D-7) correspond to faults identified from geologic mapping (fig. C-1). Resistivity increases abruptly east of the structure on the east side of Clagett Butte on the lower three frequencies and decreases for the shallower-penetrating $14,000 \mathrm{~Hz}$ frequency (fig. D-7). We infer that this boundary relates to faulting that has emplaced electrically distinct units on either side of the boundary. Slightly reduced resistivities at shallow depths to the east could be evidence for increased fracturing related to faulting. The structure on the west side of Clagett Butte appears to correspond with the northerly trending Mammoth fault discussed by Pierce and others (this volume). A zone of low resistivity is seen on dipole $0-0.25 \mathrm{E}$ at all frequencies. This is probably an expression of increased fracturing and possibly alteration along a steeply dipping fault at this position. There appears to be no significant difference in resistivity of units on either side of this dipole, so that any displacement of the inferred fault has not placed units of distinctly different electrical properties in contact, at least to the depths sampled by the $7.5 \mathrm{~Hz}$ signal $(\sim 500-1,000 \mathrm{~m})$. The strong expression at the highest frequency shows that this feature also extends to very shallow depths. The structures cannot be reliably followed to the northeast in the electrical data because of the large line separation and lack of unique electrical signature. Telluric traverses north of Clagett Butte were not run because topographic conditions made access very difficult.

Figure D-4 shows faulting in the northern part of the study area on the basis of the telluric data. The principal aspect seen in this map is a north-northeast to northeast structural trend in the interpreted faulting. In part, this is an artifact of the orientation of the traverses which tended to focus on the Reese Creek and Lava Creek faults. In addition to delineating these features, the data identify major electrical features in the Rainbow Lake and Landslide Creek areas west of Gardiner. The Rainbow Lake fault had been previously identified by geologic mapping south of traverse 22 (figs. C-1 and C-4), where a prominent scarp can be seen. This fault can be traced beneath the Quaternary cover on traverses 22 and 25 but is not evident along strike crossing line 1 (data not shown). This may be because line 1 is coincident in this area with a cross structure (identified by lines 10 and 23) that is most likely associated with an inferred fault along the axis of the asymmetric syncline in the Cretaceous sediments (see figs. C-1 and D-4). A second prominent northwest-striking boundary, conductive to the south, was identified on lines 9 and 23 but does not appear to extend eastward to line 10 .

About 1.5 miles west of the Rainbow Lake fault, the telluric data define a previously unknown, northeast-striking, feature that we infer is also due to faulting. This we informally call the Landslide Creek fault. Resistivity interpretations along traverse lines 22 and 25 (not shown) indicate low relative values at the positions of the Landslide Creek and Rainbow Lakes faults and high relative values in between these two structures, suggestive of a horst in the region of higher resistivity. The Landslide Creek fault, extended along strike as determined by lines 22 and 25 , does not appear to cross line 1. MT sounding data (fig. D-3) identify a deep, conductive, $1 \mathrm{ohm}$-meter zone near this fault, similar to those seen at the Reese Creek and Lava Creek faults, that may be evidence for hydrothermal alteration along such zones. Anomalous soil-mercury concentrations and streambed temperature were detected in the region bounded by the Landslide Creek and Rainbow 


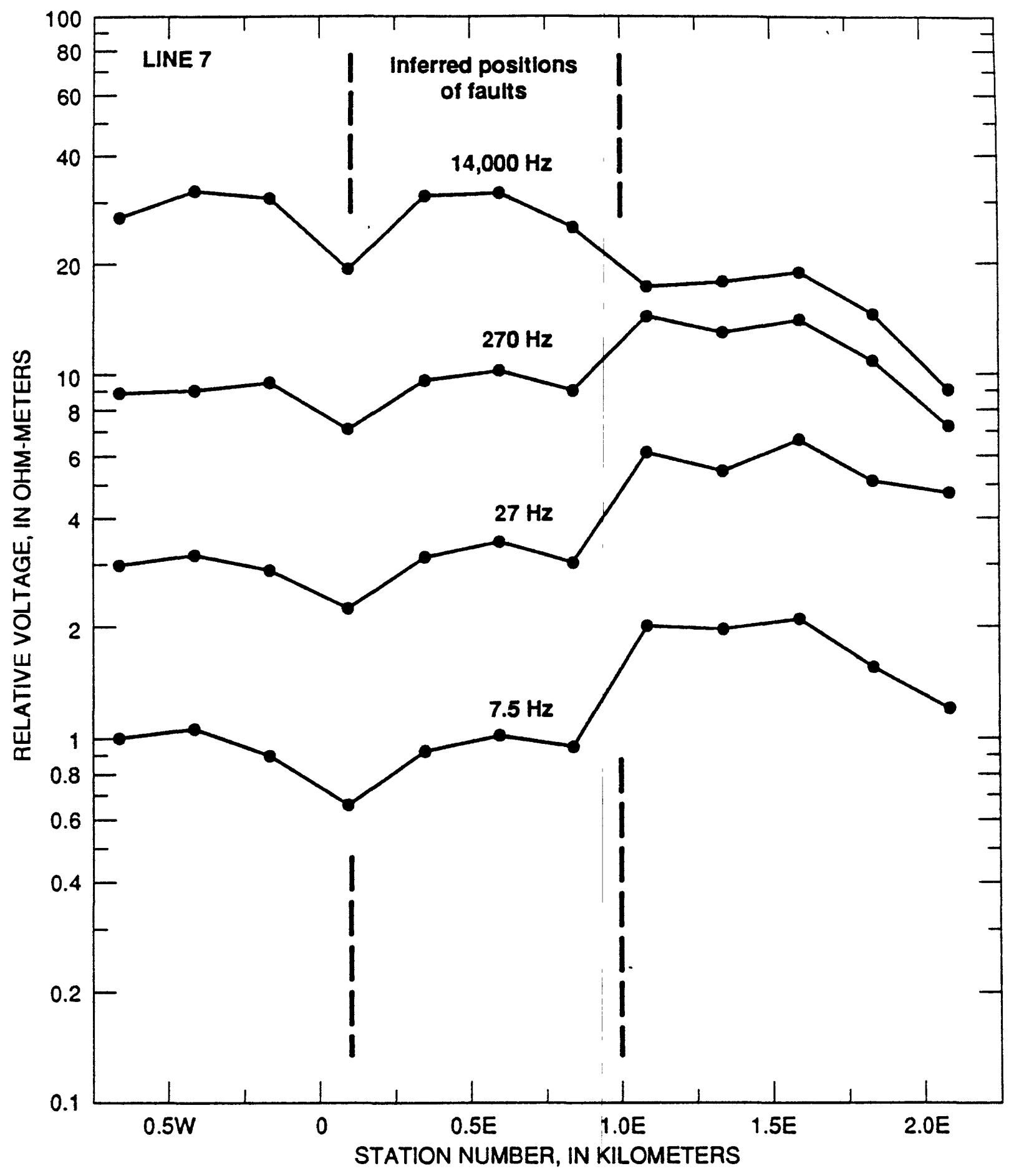

Figure D-7. Multifrequency telluric voltage data for traverse line 7 showing electrical response observed across the Clagett Butte area west of Mammoth Hot Springs. 
Lakes faults and the Yellowstone River (Hamilton and Chambers, this volume). Whether these anomalies reflect upflow of thermal water along these faults, or the postulated synclinal axis fault, is not known.

In the northwest part of the study area, the Devils Slide fault is clearly seen on traverse line 18 , at the position where it is mapped in outcrop. Several north-northeast-trending faults have been mapped in the Precambrian and Tertiary outcrops on the north side of the Yellowstone River at and west of La Duke Hot Spring. Telluric lines 15 and 16 identify one such structure between the Reese Creek fault and the Devils Slide fault southwest of the river.

\section{Summary and Conclusions}

Electrical geophysical data were obtained from 21 telluric traverse lines and 56 magnetotelluric soundings. The telluric traverse lines were run in the region between Mammoth Hot Springs and La Duke Hot Springs, focussing on the northern-boundary area of the Park where access was more favorable and where several mapped several faults that could influence subsurface flow of thermal water are located. MT soundings were made along a dominantly east-west profile and a north-south profile that covered parts of the Corwin Springs KGRA and extended to the Yellowstone caldera.

Interpretations of the MT data show generally high resistivities down to a depth of $20 \mathrm{~km}$ from $6 \mathrm{~km}$ south of Bunsen Peak northward and low resistivities (1-30 ohm-m) south of this location. Low resistivity south of Bunsen Peak is interpreted to represent hydrothermal alteration in the upper few kilometers and partial-melt conditions below depths of 6-7 km. High resistivity north of Bunsen Peak could be related to Precambrian basement and Tertiary intrusives. Low resistivity is observed beneath the Mammoth Hot Springs area, both in the upper $1 \mathrm{~km}$ and below a depths of about 10 $\mathrm{km}$. Relatively narrow, vertical conductive zones fit the MT data at three locations across the northern boundary of the Park. These zones are coincident with the Reese Creek fault and the Lava Creek fault, both mapped structures, and with an unmapped structure referred to as the Landslide Creek fault. Resistivities in these zones are low enough (1-10 ohm-m) to indicate intense hydrothermal alteration and, by implication, thermal fluid flow at present or in the past.

These same structural features in the north-boundary area are indicated in the data from telluric traverse lines run perpendicular to their strike. The telluric data also delineate faulting associated with the axis of the asymmetric Gardiner syncline south of the Yellowstone River. None of these faults could be traced further south to the Mammoth area, either because topographic conditions made access difficult or because no evidence of faulting was observed in lines run further to the south (in the case of the Lava Creek reverse fault). Although the telluric data delineate faults on the east and west sides of Clagett Butte west of Mammoth Hot Springs, no clear indication of a northeastward extension of either fault was found. Such fault extensions may not exist, or if they do exist, were not observed because of large line separation or lack of unique electrical signature.

The electrical geophysical data, therefore, confirm the existence of some faults that could have provided permeable pathways for thermal-water flow northward from the Mammoth hydrothermal system, but do not prove that such flow is currently taking place. For example, deep-seated low resistivity associated with the Reese Creek fault could be related to alteration products from the hydrothermal system supplying thermal water to La Duke Hot Spring. A similar zone associated 
with the Landslide Creek fault may be evidence for a past conduit for thermal-water flow to the Gardiner bench. Low resistivity along the Lava Creek fault in the vicinity of the Gardner River is consistent with past thermal-water flow toward travertine-depositing hot springs at Rattlesnake mound, and with present flow toward Bear Creek Springs. West of Mammoth Hot Springs, telluric data are consistent with the existence of a fault on the west side of Clagett Butte that could coincide with the Mammoth fault, suggested by Pierce and others (this volume) as a conduit for thermal water upflow.

\section{References Cited}

Beyer, J.H., 1977, Telluric and DC resistivity techniques applied to the geophysical investigation of Basin and Range geothermal systems: University of California, Lawrence Berkeley Laboratory Report, LBL-6325, 135 p.

Eaton, G.P., Christiansen, R.L., Iyer, H.M., Pitt, A.M, Mabey, D.R., Blank, H.R., Zietz, Isidore, and Gettings, M.E., 1975, Magma beneath Yellowstone National Park: Science, v. 188, p. 787-796.

Keller, G.V., and Frischknecht, F.C., 1966, Electrical methods in geophysical prospecting: New York, Pergamon Press, 523 p.

Ruppel, E.T., 1972, Geology of pre-Tertiary rocks in the northern part of Yellowstone National Park, Wyoming: U.S. Geological Survey Professional Paper 729-A, 66 p.

Smith, R.B., Shuey, R.T., Friedine, R.O., Otis, R.M., and Alley, L.B., 1974, Yellowstone hot spot: new magmatic and seismic evidence: Geology, v. 2, p. 451-455.

Stanley, W.D., Boehl, J.E., Bostik, F.X., and Smith, H.W., 1977, Geothermal significance of magnetotelluric sounding in the eastern Snake River Plain-Yellowstone Region: Journal of Geophysical Research, v. 82, no. 17, p. 2501-2514. 


\title{
CHAPTER E
}

\section{SOIL-MERCURY AND STREAMBED-TEMPERATURE ANOMALIES IN THE NORRIS-MAMMOTH-LA DUKE CORRIDOR}

\author{
By W.L. Hamilton ${ }^{1}$ and R.L. Chambers \\ National Park Service \\ (1) also Department of Earth Sciences, Montana State University
}

\begin{abstract}
Contents
Introduction.

Mercury Anomalies on Faults.

E-1

Areal Distribution of Mercury Background.

Streambed Thermal Anomalies.

Discussion

Conclusions.

Acknowledgments.

E-22

References Cited.

E-23

E-24
\end{abstract}

\section{Introduction}

Use of elemental soil mercury as an indicator of faults associated with geothermal reservoir rocks has been developed and widely applied in geothermal exploration (for example, Capuano and Bamford, 1978; Pheips and Buseck, 1980; Varekamp and Buseck, 1983; and Williams, 1985). Mercury vapor, rising from waters in reservoir rocks through open fractures and permeable zones in bedrock, moves in response to barometric-pressure variations and diffuses along temperature gradients, imparting an areal pattern of concentrations at the surface that approximately mimics the pattern of vapor loss at the bedrock surface below.

Low concentrations of mercury present in geothermal waters at depth constitute the source (White, 1967), and the flow of these waters maintains a mercury flux to the surface that over time produces an equilibrium saturation of elemental mercury in the soil. In 1984, using a Jerome $301^{2}$ gold film analyser, we resurveyed the Mud Volcano area (fig. A-1) originally sampled by Phelps and Buseck $(1978,1980)$ in 1977. The object was to see whether or not intervening earthquake activity there had changed the distribution of mercury. Increases in anomaly concentration by a factor of five in two locations showed that a rapid migration of the mercury equilibrium front could occur in response to changing vapor flux in fault zones (Bougan, 1984; Hamilton and others, 1990a).

2 The use of brand or product names in this report is for identification purposes only and does not constitute endorsement by the U.S. Geological Survey. 
In 1986 we began to look for mercury anomalies associated with mapped faults between Norris Geyser Basin and Mammoth Hot Springs (Colvard and Hamilton, 1987). Our interest arose from the need to better understand geothermal aquifers in boundary areas subject to possible geothermal development nearby. Encouraged by detection of fault-associated anomalies, we continued this work in the north boundary area (Conn and others, 1988), improving methodology with the result that we now find significant anomalies at concentrations half those reported by Phelps and Buseck (1980). Our analytical yield with gold film analysis is now 93 percent that of cold vapor atomic absorption spectrophotometry. Concentrations measured in the early stages of the work (mean yield of 60 percent of cold vapor AAS) have been corrected by multiplying by 1.5 to normalize the data set (see Hamilton and others, 1990b). Methods and results have been summarized by Hamilton and others (1990b).

As an adjunct to the mercury work, methods for detection of convective thermal anomalies in streambed sediments were developed during this study. Recognizing that heat transfer from a deep system is facilitated by thermal-water upflow where saturation extends to the surface, we surveyed streams at low flow during winter. The temperature difference (delta $T$ ) was measured between the stream water and pore water several centimeters down in the streambed using a thermocouple probe at $15 \mathrm{~m}$ intervals along the stream bank. Reproducible positive anomalies were detected, usually in association with mapped faults, and often with newly discovered thermal springs or seeps.

\section{Mercury Anomalies on Faults}

Traverse routes were laid out to cross mapped faults at approximately right angles (fig. E-1). On most traverses, sampling interval was $15 \mathrm{~m}$, and sample depth was $15 \mathrm{~cm}$ (see Hamilton and others, 1990b). Data from a part of the Black Arrow traverse in the north boundary area are illustrated in figure E-2. Background concentrations are normally distributed over a rather narrow range of about $20 \mathrm{ppb}$ (bounded by dashed lines in the figure). Anomalies stand out above the background population. Anomalies were distinguished from background by cumulative frequency analysis of concentration, as discussed by Phelps and Buseck (1980). Two of the illustrated anomalous zones are associated with mapped faults (see fig. E-1) and two are not.

We consider mean background as representing leakage of mercury vapor from a deep reservoir through relatively impermeable, homogeneous bedrock media. Anomalies are thought to represent zones of high permeability, such as fault zones, that intersect geothermal reservoir rocks at depth. Summed anomaly amplitude over a fault zone is given by $\Sigma(A-b)$, where $b$ is mean background concentration and $\mathrm{A}$ is any concentration exceeding the background envelope. Mean background concentrations along each traverse were determined graphically. Values of summed anomaly amplitude were determined for each cluster of mercury concentrations above background values along each traverse. On the Black Arrow traverse segment shown in figure E-2, and in many other cases, anomalous zones consist of from one to four peaks over a horizontal distance of from 15 to $150 \mathrm{~m}$. Some of the wider anomalies probably reflect situations where the fault zone was traversed at a non-perpendicular angle. 
All traverses in the study area and their associated summed anomaly amplitudes are illustrated in figure E-1. Faults have been adapted from U. S. Geological Survey (1972) and figure C-1 (Pierce and others, this volume). Most mapped fault traces exhibit anomalies, but anomalies were also detected at locations where faults have not been recognized--especially on longer traverses. Strongest anomalies were found near Norris Geyser Basin and Horseshoe Hill in the southern part of the study area. To the north, the strongest anomalies were seen near Mammoth Hot Springs, the town of Gardiner, and the area near the mouth of Reese Creek in the Yellowstone River Valley.

Phelps and Buseck (1980) attributed the decline in mercury anomaly amplitude northward from Norris to the Mammoth area to depletion by steam loss to the south. Hamilton and others (1990b) interpreted clear trends in anomaly amplitude in terms of such vapor-loss-depletion of mercury in aquifers intersected by the faults. We noted, for example, that anomaly amplitude declined approximately logarithmically northward along faults between Horseshoe Hill and the Mammoth area, consistent with loss of mercury by waters moving northward at depth. The summed anomaly data in figure E-1 show this depletion consistent with northward transport of geothermal waters from the Horseshoe Hill - Norris area to the park boundary area west of the town of Gardiner, where thermal waters are thought to enter the footwall of the Gardiner reverse fault. Relatively strong anomalies are found $1 \mathrm{~km}$ west of Gardiner, northwest on the axis of the Gardiner syncline, and farther to the northwest along the Gardiner fault in the Little Trail Creek and La Duke areas. These observations suggest movement of thermal water beneath these areas. Anomalies northeastward in the Bear Creek Spring area are much smaller.

Local inconsistencies in the reservoir-depletion model can be attributed in part to variable permeability in fault zones from place to place, as suggested by the data of Phelps and Buseck (1980). Permeability reduction is expected to result from accumulation of hydrothermal precipitates in aseismic fault zones over time. As more data have been acquired in the north boundary area, we find that anomaly amplitude can change considerably on the same fault trace sampled several hundred meters farther on. Mercury anomalies in areas with no mapped faults may be attributed to previously undetected faults, fracture zones, or steeply dipping permeable beds associated with geothermal waters at depth.

\section{Areal Distribution of Mercury Background}

Mercury background is thought to be less affected by variable permeability. Figure E-2 showed how mercury background concentrations are constrained, and the figure indicated some variation in background along a traverse. Background contours interpolated from mean mercury background are plotted in figure E-3. Background concentration values over the entire study area are highest $(>40 \mathrm{ppb})$ at the Horseshoe Hill vapor-dominated system and at Norris, with the suggestion of an interconnected high zone including Roaring Mountain. Lowest background $(<20$ ppb) was measured in the Mammoth Hot Springs area, in the Yellowstone River Valley - Gardiner travertine bench area between Bear Creek and Little Trail Creek, in an area about $4 \mathrm{~km}$ south of La Duke, and near the Yellowstone caldera boundary east of Norris. 


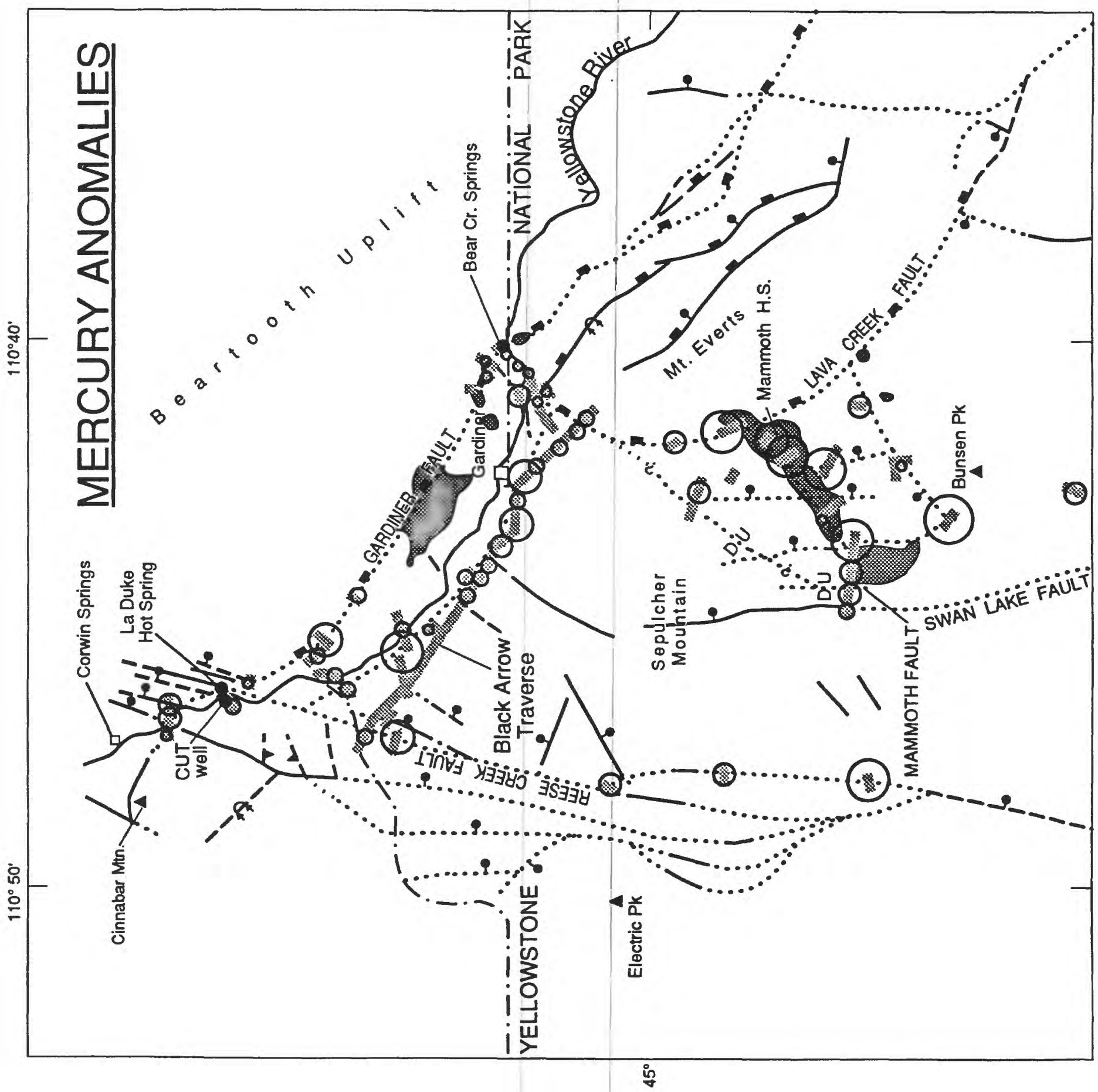




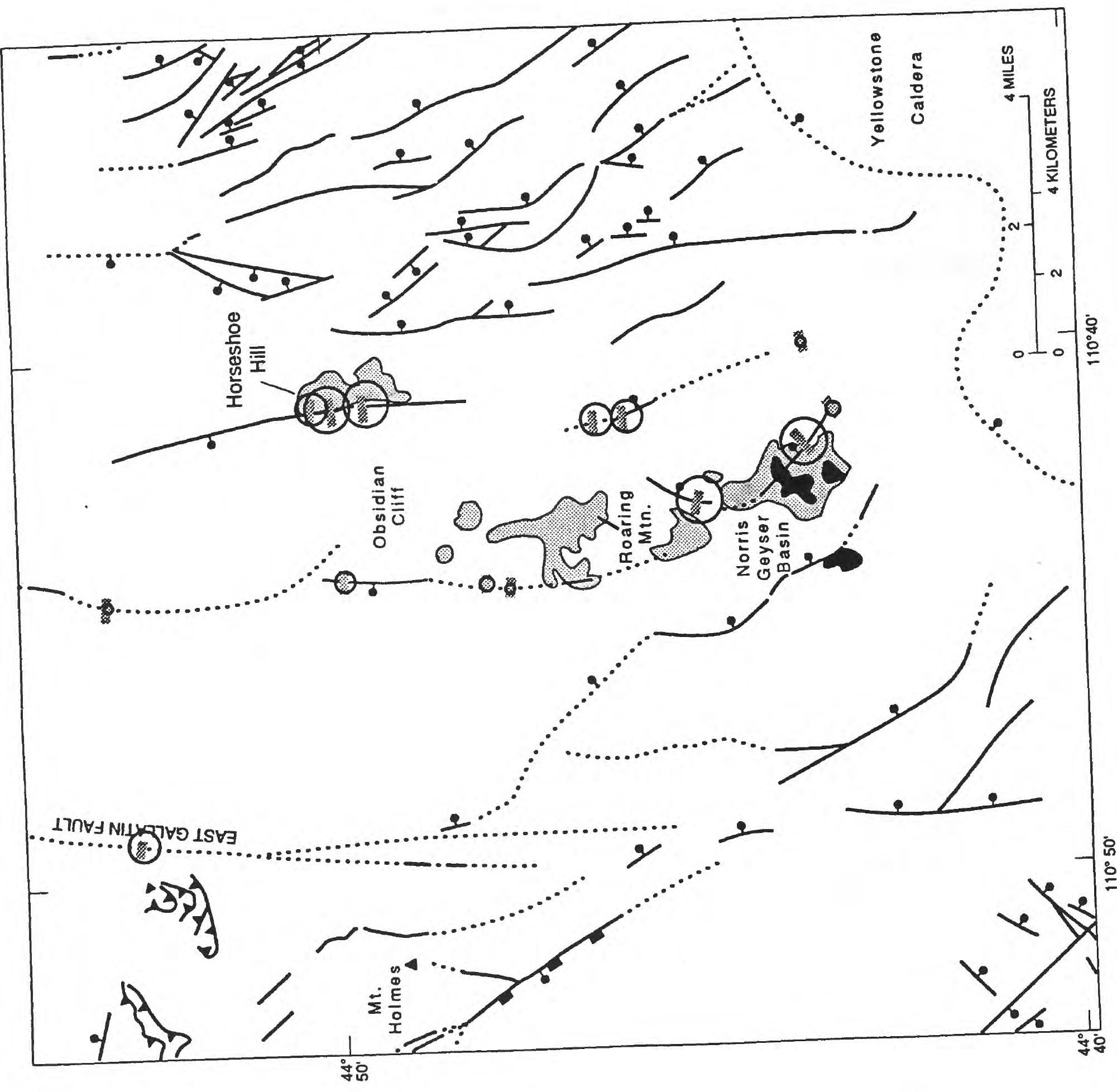




\section{EXPLANATION}

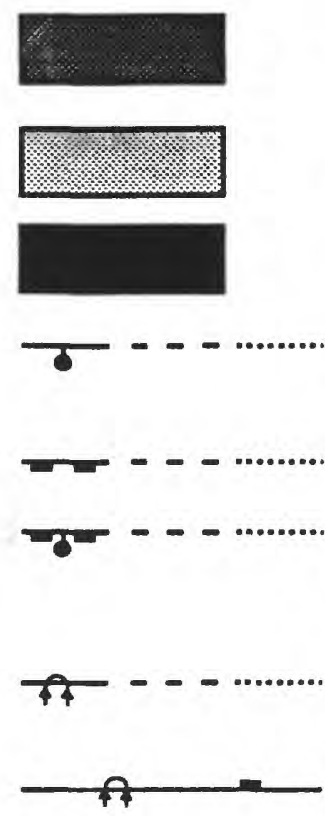

Travertine

Acid hydrothermal alteration

Siliceous sinter

Normal fault--Dashed where inferred; dotted where concealed; queried where uncertain. Bar and ball on downthrown side.

Reverse fault--Dashed where inferred; dotted where concealed

Reverse fault along which later normal faulting took place--Dashed where inferred; dotted where concealed. Block teeth on overriding block. Bar and ball on downthrown side.

Axis of asymmetrical, overturned syncline--Dashed where inferred; dotted where concealed.

Axis of asymmetrical, overturned syncline with known or inferred reverse fault

- - U_ - - - - - Fault with unknown dip--queried where doubtful. Sense of displacement indicated by $D$ (down) and $U$ (up).

Soil-mercury traverse

$\left\{\begin{array}{l}>20 \\ >50 \\ >100 \\ >>200 \\ >500 \\ >1000\end{array}\right]$

Figure E-1. Locations and amplitudes of mercury anomalies and locations of soil-mercury traverses in the Norris-Mammoth corridor. 


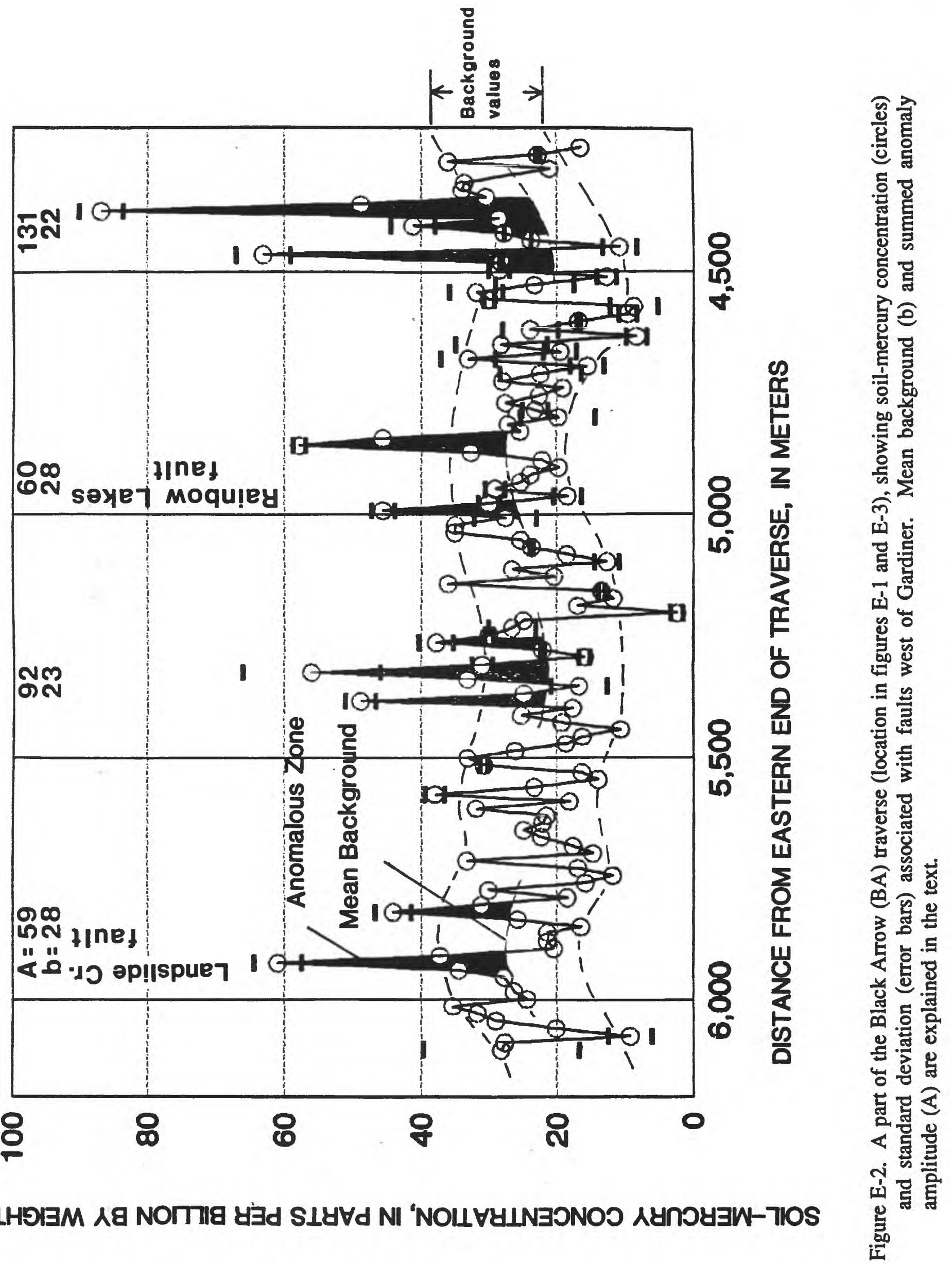




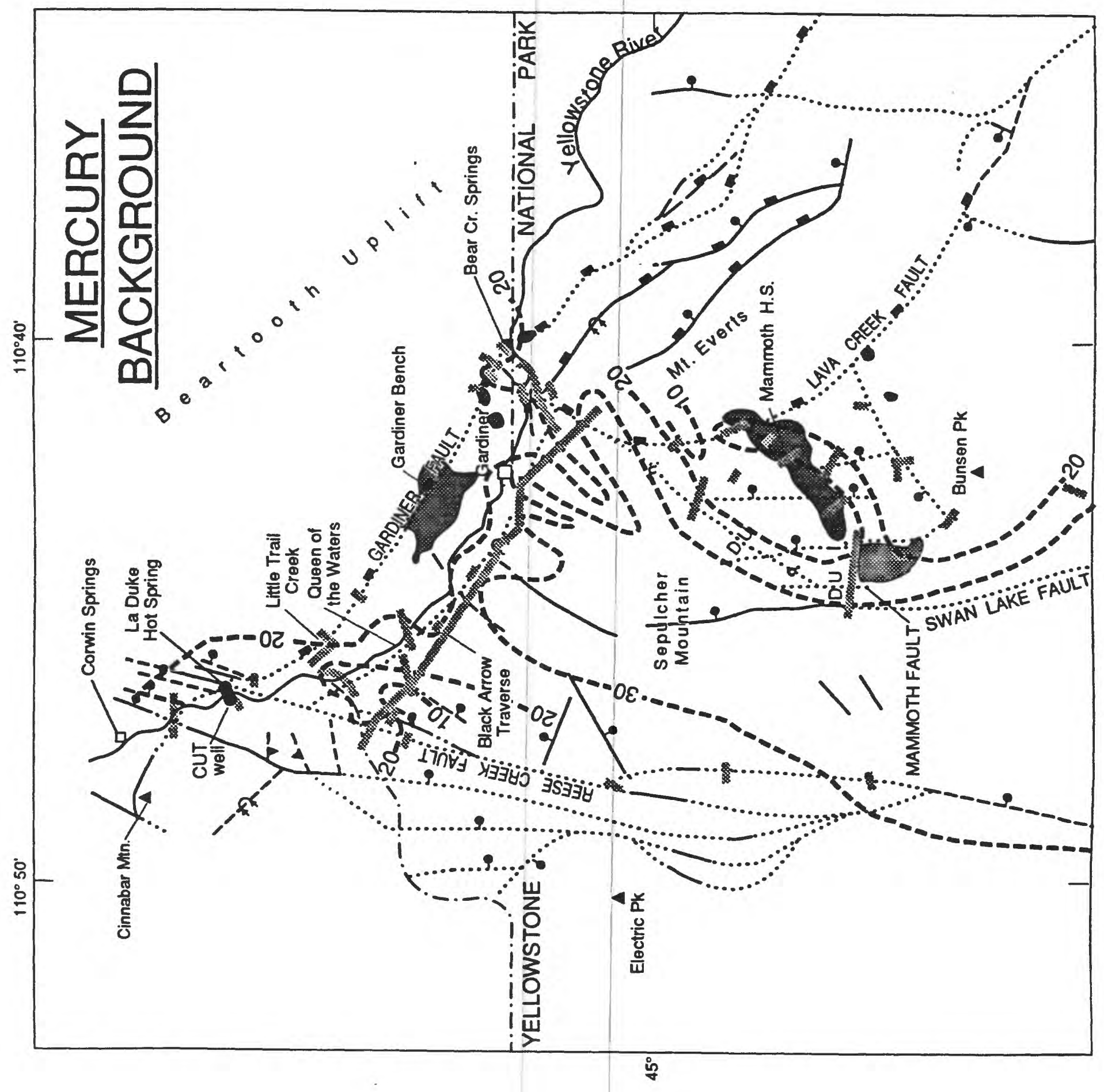




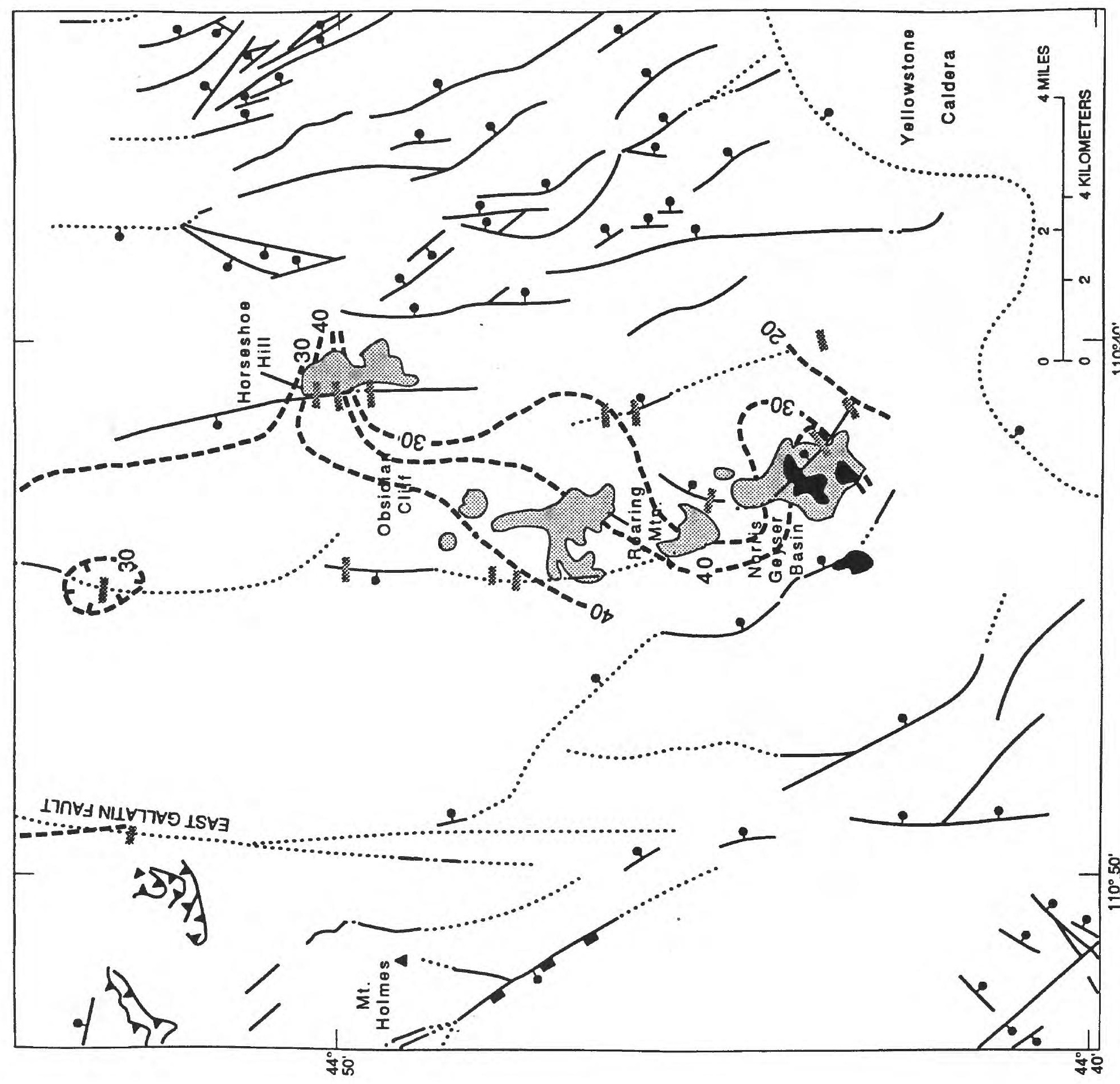




\section{EXPLANATION}
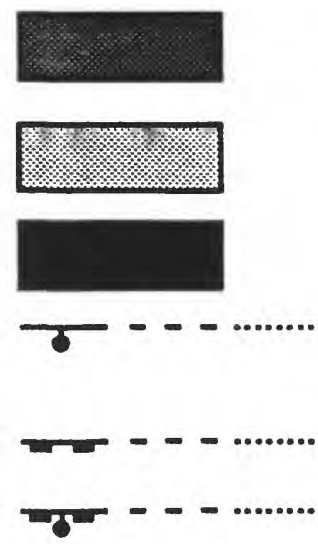

की
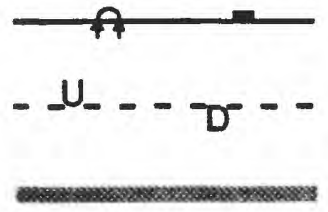

$---30$
Travertine

Acid hydrothermal alteration

Siliceous sinter

Normal fault--Dashed whe nferred; dotted where concealed; queried where uncertain. Es and ball on downthrown side.

Reverse fault--Dashed where inferred; dotted where concealed

Reverse fault along which later normal faulting took place--Dashed where inferred; dotted where concealed. Block teeth on overriding block. Bar and ball on downthrown side.

Axis of asymmetrical, overtumed syncline--Dashed where inferred; dotted where concealed.

Axis of asymmetrical, overtumed syncline with known or inferred reverse fault

Fault with unknown dip--queried where doubtful. Sense of displacement indicated by $D$ (down) and $U$ (up).

Soil-mercury traverse

Line of equal mercury backgound concentration in parts per billion (ppb).

Figure E-3. Contours of mercury-background concentration and locations of soil-mercury traverses in the Norris-Mammoth corridor. 
High background areas are presumed to be locations where deep upwelling charges aquifer rocks with mercury-rich waters. The Madison Group (limestone and dolomite) crops out near Roaring Mountain and lies close below the surface at Horseshoe Hill, and it is thought to be a likely candidate as a regional aquifer (Struhsacker, 1976). The low background areas are arguably at locations where an aquifer in bedrock is likely to be blocked by offset or disruptions: for example, at the caldera boundary fault; at the inferred location of a thrust zone along the axis of the Gardiner syncline (see figs. E-7 and C-2); and marginal to areas likely to be injected with dikes or larger intrusive bodies of Eocene age (Electric Peak and Bunsen Peak), as well as late Quaternary intrusives south of Bunsen Peak. Background concentrations (and anomalies) are low on the hanging wall block of the Gardiner fault except at Bear Creek and in the La Duke area. We attribute these high values to aquifer continuity produced by cross-cutting fault structures in these areas.

Areas of similarly elevated mercury-background concentrations could reflect regional hydrologic continuity in underlying thermal-water aquifers, although sparse data coverage makes such an interpretation speculative. Similar contours (not shown) were derived from the summed anomaly-amplitude data set. A high-background zone may exist from north of Roaring Mountain to Sepulcher Mountain west of Mammoth and beyond to the north boundary, where background values are consistently between 20 and $30 \mathrm{ppb}$ (fig. E-3). A lobe of $>30 \mathrm{ppb}$ background values appears to strike toward the area of Quaternary travertine outcrop on the Gardiner bench. Another appears to strike toward Bear Creek Springs, where an irregular $>20 \mathrm{ppb}$ zone is delineated. A $>20$ $\mathrm{ppb}$ lobe can be traced from the Terrace Mountain travertine area into Mammoth Hot Springs, where it appears to parallel the area of late Quaternary travertine deposition before terminating in the footwall of the inferred Lava Creek reverse fault. The low background on the Mammoth Terraces argues for lateral transport from what may be a deep, narrow aquifer originating in the area near the north end of Terrace Mountain.

Contours based on more detailed coverage in the north boundary-KGRA area (fig. E-3) suggest a zone of $>20 \mathrm{ppb}$ background trending northwestward from the Queen of the Waters fishing access area to Little Trail Creek, and possibly extending to La Duke and beyond. Anomalously high mercury concentrations and streambed-temperature anomalies at several locations, as discussed below, are also indicative of movement of thermal water in this region.

\section{Streambed Thermal Anomalies}

Several previously-undetected zones of convective heat input were discovered along the banks of the Yellowstone and Gardner Rivers by measuring streambed-temperature anomalies during lowflow conditions early and late in 1990. As the streams rose in March and April, anomalies were greatly suppressed. Figure E-4 shows delta $\mathrm{T}$ (streambed temperature - stream water temperature) measurements along the east bank of the Gardner River downstream from hot spring MHS-2 to the Chinese Garden area at the 45 th parallel. Sizeable warm seeps (about $25^{\circ} \mathrm{C}$ ) were discovered at Chinese Garden. The anomalous zone immediately downstream from Hot River was somewhat suppressed because the river was warmed about $1.5^{\circ} \mathrm{C}$ at that point by Hot River or streambed 


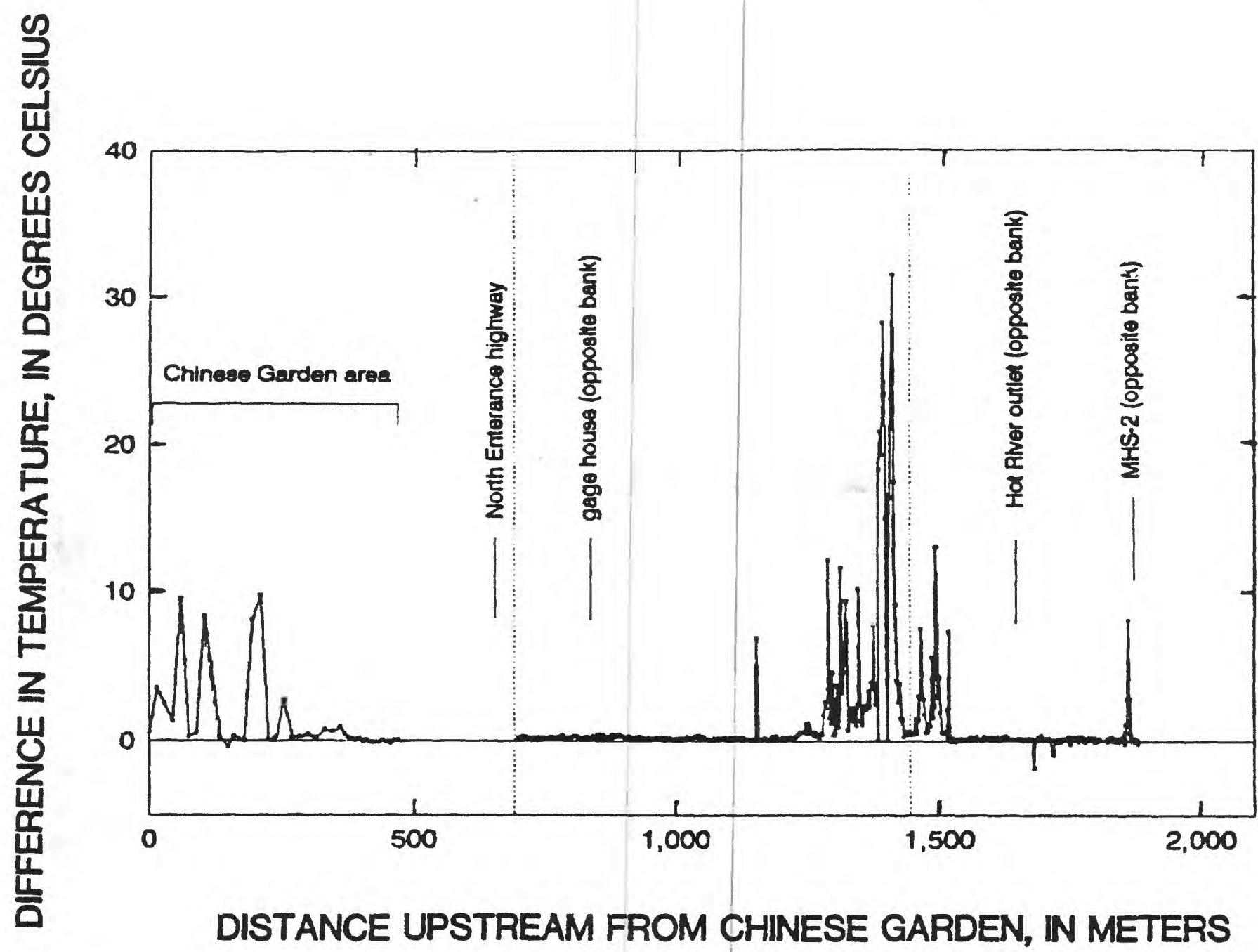

Figure E-4. Streambed-temperature anomalies on the east bank of the Gardner River in the Chinese Garden - Hot River area near Mammoth Hot Springs. 
seeps. Small negative anomalies may be cold springs or fine bottom sediment that retained its nighttime temperature at the time of measurement.

A part of the MHS-2 - Hot River thermal-anomaly data are shown in map view in figure E-5. Areas with streambed thermal anomalies $>1^{\circ} \mathrm{C}$ are shown with a stippled pattern. The strikes of the two anomalous zones (constrained at MHS- 2 by the spring itself) are similar, and they parallel an extension of the inferred northeast-striking fault shown near this location by U. S. Geological Survey (1972).

The location of the Boiling River (BR) mercury traverse is also shown in the figure E-5. Small mercury anomalies were found at the north and south ends of the line. Subsequently the Hot River (HR) mercury traverse was sampled north of the BR line within the stippled area. It yielded a summed anomaly amplitude of $220 \mathrm{ppb}$. Mercury anomalies appear to be displaced slightly downstream from the west-bank thermal anomalies.

Thermal anomalies on the Gardner and Yellowstone Rivers are illustrated along with mercury traverse data in figure E-6. Areas where delta $T$ exceeded 1 degree $C$ are indicated by black bars. Numbered labels alongside thermal anomalies represent highest values of delta $T$ in respective anomalous zones. Anomalies are found on the Gardner River at the Hot River area (see fig. E-5), at Chinese Garden, associated with the Lava Creek reverse fault downstream, and at one location farther downstream. Warm springs $\left(25^{\circ}\right.$ to $\left.26^{\circ} \mathrm{C}\right)$ are associated with the Chinese Garden anomalous zone in sloughs on both sides of the river. Chinese Garden anomalies were suppressed $10^{\circ}$ to $20^{\circ} \mathrm{C}$ because the stream temperature is elevated in this area due to thermal water input from Hot River. Late winter (1990) soil-temperature measurements corroborated the northeast strike of this zone, and mercury anomalies on the west bank were in good agreement with this interpretation. Again, as at Hot River, there was a tendency for mercury anomalies to be displaced downstream with respect to thermal anomalies.

Weak thermal anomalies, suppressed about $10^{\circ} \mathrm{C}$ by Hot River input upstream, near the location where the Lava Creek fault crosses the Gardner River are inferred as parallel to steeplydipping calcite-mineralized Cretaceous beds there. Sizeable mercury anomalies are also present on the Black Arrow traverse at that location. A single $1.5^{\circ} \mathrm{C}$ thermal anomaly between there and the Yellowstone River is thought to be associated with the inferred trace of the faulted syncline, shown by the dashed line trending westward through a cluster of mercury anomalies near the town of Gardiner.

Only two, modest streambed thermal anomalies were found on the north bank of the upper reach of the Yellowstone River, a short distance downstream from the confluence of Bear Creek. These appear to be associated with faults shown at that location by Fraser and others (1969), but they were not detected on the south bank. Two mid-stream thermal springs are inferred at the locations indicated in figure E- 6 by open circles just downstream on the basis of local warming of the river by $0.6^{\circ}$ to $1.0^{\circ} \mathrm{C}$. The downstream input, most likely located inside the park boundary, was corroborated when the section was resurveyed within an hour. Each of these anomalous areas 


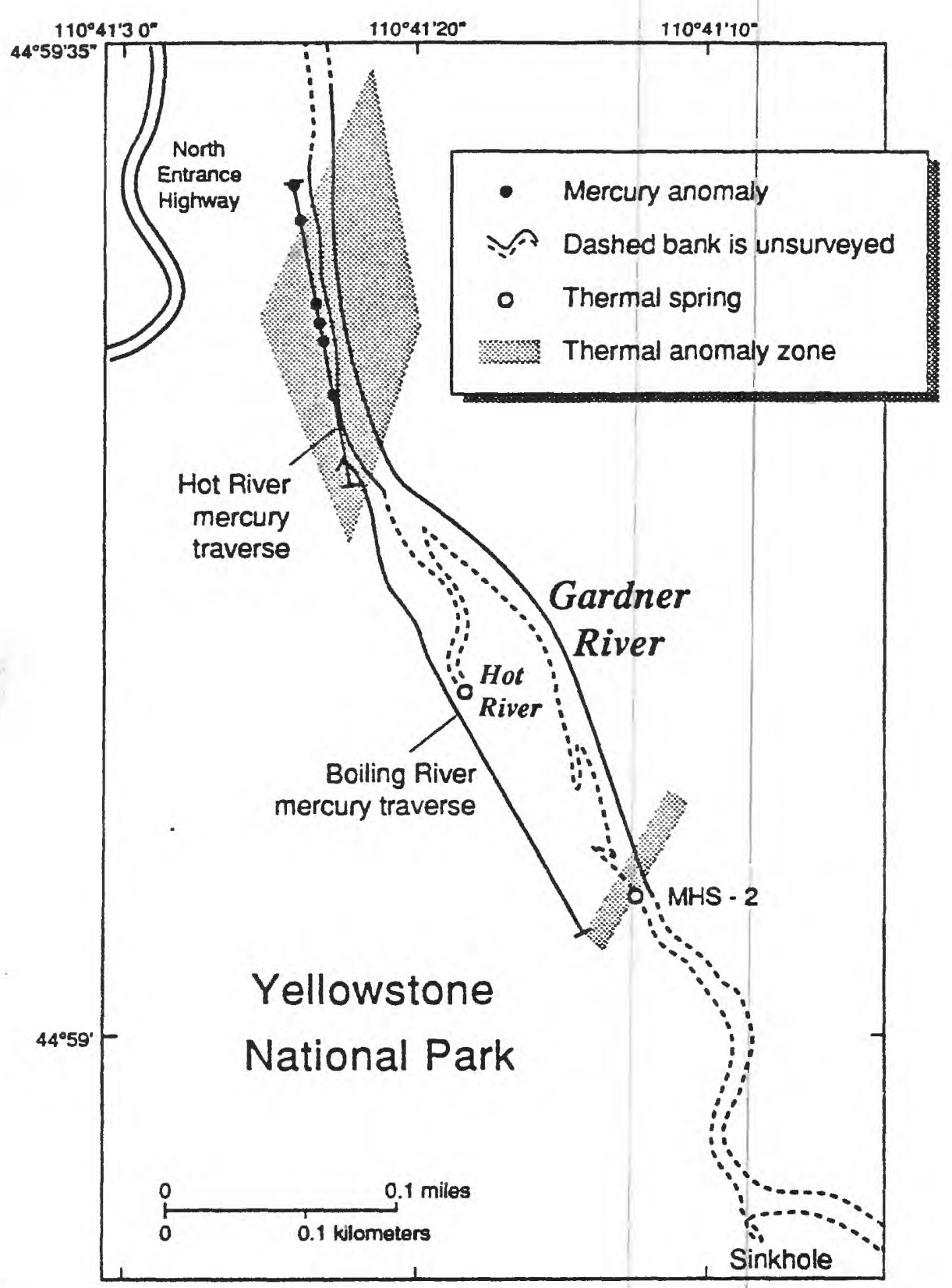

Figure E-5. Soil-mercury traverses and streambed-temperature surveys near Hot River. 


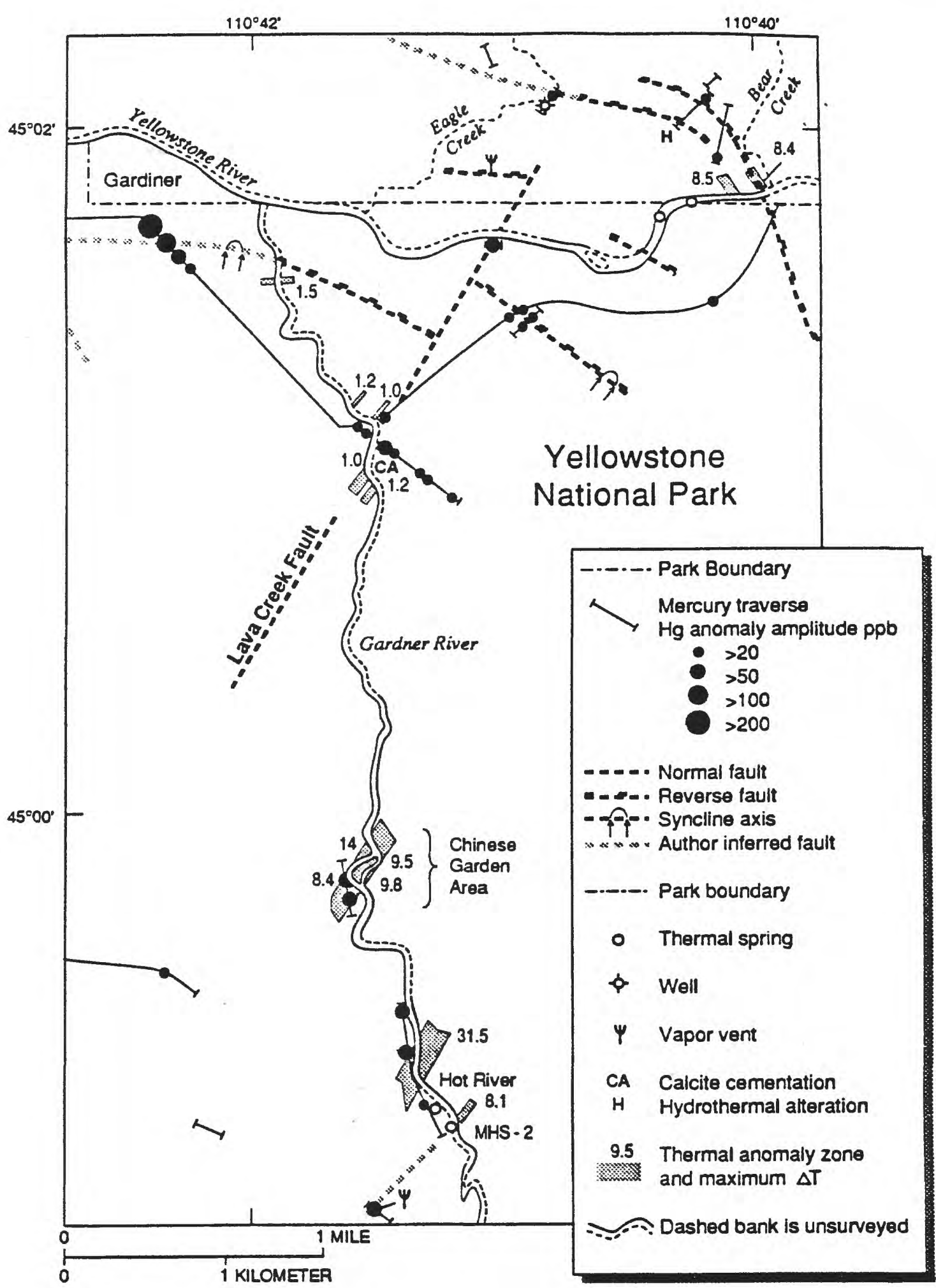

Figure E-6. Thermal-anomaly zones on the Gardner and Yellowstone Rivers and soil-mercury traverses between the Hot River area and the north boundary of Yellowstone National Park. Faults indicated with solid dashes are based on published maps (Fraser and others, 1969; U.S. Geological Survey, 1972). Those shown by open dashes are inferred from alignment of altered areas or the axis of the overturned Gardiner syncline (fig. C-1, Pierce and others, this volume). Difference between streambed temperature and stream water temperature, in degrees Celsius, given by $\Delta \mathrm{T}$ in Explanation. 
is within the reach where data from integrated river-water samples indicate input of thermal water at rates in excess of the estimated flow of vent BC-1 at Bear Creek Springs (Sorey and others, this volume). No thermal anomaly was found on the south bank farther downstream, where a mercury anomaly was associated with the Lava Creek fault.

Figure E-7 shows locations of thermal-anomaly zones and mercury anomalies downstream along the Yellowstone River in the Gardiner airport area. The Landslide Creek and Rainbow Lake fault locations are based on the results of telluric traverses (Stanley and others, this volume). The location of the fault trace shown parallel to the Yellowstone River in figure E-7 is also based on the telluric results and is coincident with the axis of the asymmetric-to-overturned syncline shown on the geologic map (fig. C-1). This Gardiner fault footwall structure is inferred to extend to the southeast through the area of larger mercury anomalies just west of the town of Gardiner.

A series of five small thermal anomalies was surveyed in the lower $0.5 \mathrm{~km}$ of Landslide Creek. Several of these zones had associated watercress growing in the streambed, implying alkaline spring inputs. Strikes of these zones are unconstrained, except by inference to the structure noted at this location by Stanley and others (this volume). A single, narrow anomaly was detected farther upstream on Landslide Creek. On the Yellowstone River near the airport, streambed thermal anomalies were detected close to the Gardiner municipal well. Initial chemical analysis of the well water in November 1985 gave sulfate, chloride, and specific conductance values of $61 \mathrm{mg} / \mathrm{L}, 9$ $\mathrm{mg} / \mathrm{L}$, and $380 \mu \mathrm{S} / \mathrm{cm}$; but with continued pumping that winter concentrations dropped by half. With continued use over the next three years, this well has shown a 2.5 -fold increase in solute concentrations, including sulfate and arsenic, reverting to its original composition. On 15 June, 1989 , the well water tested $62 \mathrm{mg} / \mathrm{L}$ sulfate and $430 \mu \mathrm{S} / \mathrm{cm}$ specific conductance.

A small, $7.6^{\circ} \mathrm{C}$ seep was found at the $2.6^{\circ} \mathrm{C}$ anomaly on the south bank. A water sample from this seep showed values of specific conductance, sulfate, and chloride of $390 \mu \mathrm{S} / \mathrm{cm}, 73 \mathrm{mg} /$, and $11 \mathrm{mg} / \mathrm{L}$, respectively. The north-bank survey was done after river discharge had increased in the spring, which may explain why fewer anomalies were found there. The strike of these zones was inferred by correlating the north bank anomaly with the seep, and it approximately parallels strikes of the Rainbow Lake and Landslide Creek faults and the strike-slip feature mapped east of the airport by Fraser and others (1969).

The Black Arrow mercury traverse line is indicated south of the river in figure E-7. The Rainbow Lake and Landslide Creek faults are thought to project near locations of two soil-mercury anomalies (see fig. E-2). The Rainbow Lake fault also projects near an area of calcite cementation observed within the large landslide mass described by Waldrop and Hyden (1963). Bedrock slabs incorporated into the debris may help to provide surficial control of mercury diffusion.

A short offset mercury traverse was sampled north of the Black Arrow traverse line in an attempt to constrain the strike of one of the mercury anomalies. The offset anomaly is in approximate alignment with the inferred strike of the river thermal anomalies in this area and with the small anomaly far upstream on Landslide Creek. While further work would be required to confirm inferred structural trends in this area, evidence is consistent with intersection of northeast- 


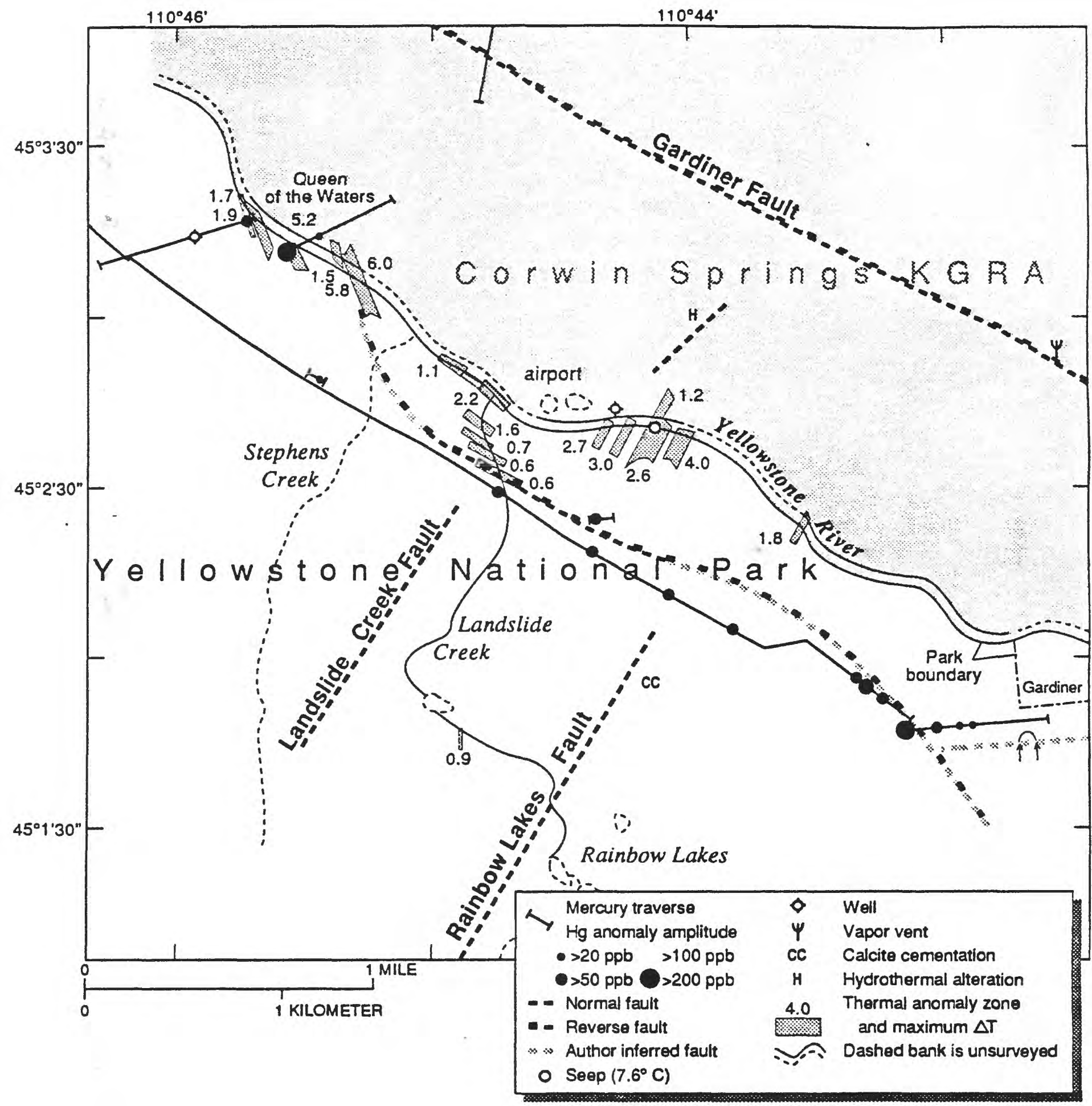

Figure E-7. Streambed thermal anomaly zones and mercury anomalies in the Gardiner airport area. The Gardiner municipal well is located near the airport. Faults indicated with solid dashes are based on figure C-1 (Pierce and others, this volume) and figure D-4 (Stanley and others, this volume). Those shown with shaded dashes are inferred along the axis of the overturned Gardiner syncline and from mercury and streambed-temperature anomalies at Queen of the Waters. The difference between streambed temperature and stream water temperature, in degrees Celsius, is given by $\Delta \mathrm{T}$ in Explanation. 
striking normal faults with northwest-striking stratigraphic units and faults within the footwall of the Gardiner fault southwest of the Yellowstone River. Anomalies suggest that some normal faults may extend to and across the river.

Farther downstream one thermal anomaly appears to strike north-northwest across the river, and other thermal anomalies on the west bank align reasonably well with mercury anomalies encountered on the Queen of the Waters traverses at this location (recent sign changes show this now to be called the McConnell fishing access). Here strikes of four of these zones are relatively well constrained in a north-northwesterly direction, suggesting that the footwall structure crosses the Yellowstone River striking directly toward the lower Little Trail Creek area (see fig. E-8).

Streambed-temperature surveys were condycted along the Yellowstone River and portions of Reese and Little Trail creeks in the La Duke area, and results are summarized in figure E-8. Areas of meters-thick caliche accumulation are indicated by CA symbols. These may be related to evaporation of upwelling alkaline waters through thick gravels. Highest east-bank anomalies $\left(>30^{\circ} \mathrm{C}\right)$ were found immediately upstream from La Duke. Several sizeable hot springs were discovered at the Corwin springs location in the course of this survey (for example, $52^{\circ} \mathrm{C}$ ), and highest west bank anomalies were associated with a hot spring $\left(38^{\circ} \mathrm{C}\right)$ and warm seeps at the Mink spring area. Three thermal wells, discussed by Sorey and others (this volume) are also indicated in the figure.

Approximately $1 \mathrm{~km}$ south of La Duke, well-constrained fault structure is inferred from modest thermal anomalies on both sides of the river. These align well with the location of the Reese Creek fault (Stanley and others, this volume). We project this broad zone to La Duke on the basis of streambed anomalies as high as $44^{\circ} \mathrm{C}$ with numerous hot springs along the east bank, caliche areas, and a broad anomalous mercury zone on the La Duke bench traverse. Spring-box sediment at La Duke contained up to $1,840 \mathrm{ppb}$ mercury, an order of magnitude greater than that measured in soil nearby. Higher temperatures on the east bank in this zone suggest the possibility of greater hydrothermal upwelling closer to the Gardiner fault east of the river.

Farther downstream (north), anomalous zones with hot springs (Mink and Corwin) are inferred as striking parallel to the Gardiner fault. These zones are thought to align with mercury anomalies detected on the Corwin Springs traverse that crosses the valley to the north.

Large mercury anomalies were detected on traverses near Little Trail Creek and at Queen of the Waters in the early stages of the investigation. Subsequently we anticipated sizeable anomalies where we sampled on the east bank of the river east of Reese Creek. Our prediction proved correct. Moreover, a broad $(190 \mathrm{~m})$, low thermal anomaly at the park boundary at the latter location is thought to align with mercury anomalies on the opposite bank, striking northeastward toward Little Trail Creek where a very small thermal anomaly was detected. These data, along with high mercury-background values in this area and at La Duke (fig. E-1) may be indicative of a geothermal aquifer beneath the north-boundary area extending from Queen of the Waters to the Reese Creek/Little Trail Creek area and beyond to La Duke. Zones of enhanced permeability in this region could be provided by north-northeast-trending segments of the Reese Creek fault system or 


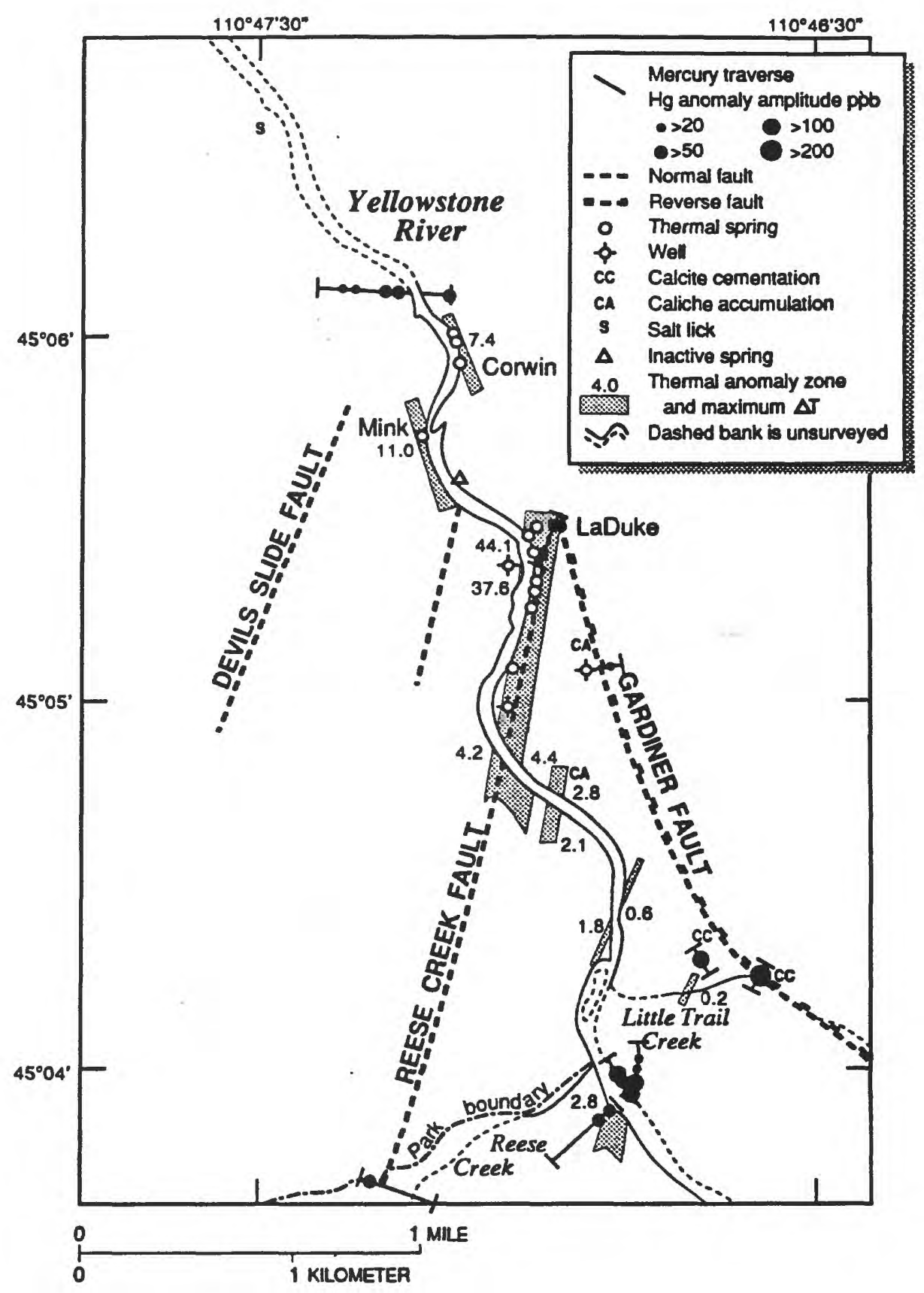

Figure E-8. Streambed thermal anomaly zones and mercury anomalies near La Duke Hot Spring. Selected fault segments from figure C-1 (Pierce and others, this volume) and figure D-4 (Stanley and others, this volume). Difference between streambed temperature and stream water temperature, in degrees Celsius, given by $\Delta \mathrm{T}$ in Explanation. 
northwest-trending faults associated with the overturned axis of the Gardiner syncline. Confirmation of such an interpretation would require data from test drilling; the only existing well within the Park in the north-boundary area (fig. E-7, west of Queen of the Waters) is $27 \mathrm{~m}$ deep and shows isothermal temperature conditions at $9^{\circ} \mathrm{C}$ (Sorey and others, table G-5, this volume). This indicates that the weak thermal anomalies between Reese Creek and the Gardiner airport have normal groundwater temperatures.

\section{Discussion}

The aim of these investigations is to answer the question of hydrologic continuity between hot springs in the Corwin Springs KGRA and those inside Yellowstone National Park, which requires determining the lateral extent of a system or systems at depth. Only tracer or well-test response experiments have the potential to answer this question directly. Geological and geophysical studies provide data that can lead to inferences regarding structural opportunities for aquifers, or the blockage thereof (Pierce and others, this volume; Stanley and others, this volume). Hot-spring water chemistry can provide information on rock-water interactions, mixing, boiling, and dilution, enabling inferences as to relatedness of waters at hot springs separated by distance (Kharaka and others, this volume). Hydrologic studies incorporate these findings with discharge and temperature data to draw inferences regarding hydrostatic head and flow (Sorey and others, this volume). Each of these investigations utilizes models in arriving at conclusions.

The occurrence of hot springs, streambed thermal anomalies, and mercury anomalies at faults suggests an association that we consider the basis of a model. Such a fault zone probably intersects a geothermal reservoir or aquifer at depth, and a permeable fault zone may provide vertical and lateral hydrologic continuity. In such a case surface manifestations in the zone would represent reservoir or aquifer conditions modified during the ascent of the waters to the surface. The thermalanomaly temperature and mercury-anomaly amplitude represent conditions at depth in the same sense that springwater chemistry and temperature do. Streambed thermal anomalies on the bank of the Yellowstone River near La Duke occur in a broad band that is parallel with the mapped trace of the Reese Creek fault, and with an alignment of hot springs and warm springs below the high water line of the river. The occurrences of thermal springs suggest that the Reese Creek fault hydrothermal zone has a length of $0.6 \mathrm{~km}$, but when thermal anomaly data are included, the length of continuity is nearly doubled. Higher streambed temperatures nearer to La Duke suggest greater vertical communication at the northern end of this zone.

At Chinese Garden and Hot River streambed thermal anomalous zones strike northeast across the Gardner River. While absence of bedrock outcrops precludes confirmation of associated faults, the zones are parallel to nearby inferred fault traces. In these cases streambed thermal anomalies suggest that fault-associated thermal manifestations are more widespread than one would conclude from the mapped distribution of thermal springs alone, arguing either for lateral transport in the fault zone or a more widespread reservoir or aquifer at depth.

Moreover, at La Duke, near the mouth of Reese Creek, Queen of the Waters, Chinese Garden, 
and Hot River we found that thermal anomalies were also associated with soil-mercury anomalies on trends that parallel nearby inferred faults. We have argued that water saturation from surface to depth is required to support convection that makes thermal anomalies evident. Free-mercury anomalies on the other hand are supported at the surface sometimes at a considerable distance above the water table in fault zones having hydrothermal influence. Thus we argue that thermal springs, streambed thermal anomalies, and mercury anomalies are all manifestations of upward transport in a fault zone, requiring lateral flow to conserve mass. Lateral flow may occur in the fault zone at relatively shallow depth or in a reservoir or aquifer intersected by the fault at depth. Where anomalies are found on each transect of a mapped fault confidence is improved that hydrologic communication is occurring in the unsampled portion of the fault as well, or in the associated reservoir or aquifer.

Throughout the investigation we have located new traverses to test this conceptual model (Hamilton and others, 1990b). After a mercury anomaly was found on the trace of the Lava Creek fault near the Gardner River we traversed the fault at the Yellowstone River, finding another anomaly. We subsequently traversed the fault trace at another location at the Gardner River, finding an anomaly within meters of the predicted location. This procedure was followed when planning short offset traverses parallel to the Black Arrow traverse at anomaly locations and at three locations on the Reese Creek fault. This was our rationale also in locating mercury traverses to check estimates of strike of thermal anomalies in cases where orientation was constrained by anomaly boundaries on both banks (and in unconstrained cases). So far this procedure has allowed confirmation of the model within reasonable limits in all cases.

When mercury anomalies $>100 \mathrm{ppb}$ were found at lower Little Trail Creek (LLTC) comparable to anomalies at Mammoth, cross-valley traverses were sampled northwest and southeast of that area in an attempt to locate evidence of continuity with a water of comparable mercury concentration. The southeast Queen of the Waters (QW) traverse succeeded in identifying two such anomalies. At this point we still also considered a Reese Creek fault association for the LLTC anomalies on the basis of a $>100 \mathrm{ppb}$ anomaly in upper Reese Creek canyon, but a much smaller anomaly farther north in the canyon made this unconvincing. Subsequently when $>100 \mathrm{ppb}$ anomalies were located a kilometer west of Gardiner we began to think seriously about continuity of this system within a permeable unit in the footwall of the Gardiner fault between there and LLTC (including QW). Other traverses were then sampled between QW and LLTC near the mouth of Reese Creek to test this hypothesis. They revealed $>100 \mathrm{ppb}$ anomalies northeast of the river associated with a broad thermal anomaly on the river bank, lending further support to the model and to our interpretation of continuity over a distance of more than $5 \mathrm{~km}$. While it is too early to rule out continuity southward along the Reese Creek fault zone, we consider this less likely on the basis of low mercury background to the south (discussed below). While our evidence of continuity does not extend all the way to La Duke, it comes close enough $(2.6 \mathrm{~km})$ to suggest a plausible association and shows us where the next mercury traverse should be located.

Mercury diffusion is relatively unimpeded by the thick valley fill between Gardiner and $\mathrm{La}$ Duke, but fine sediments apparently restrict upward fluid mobility so that thermal springs are evident only on the northeast valley wall where fill is thin. Even so, modest streambed thermal 
anomalies were discovered at locations along the river bank that support our view of hydrologic continuity and an association with footwall block structure.

Previously we had considered (Hamilton and others, 1990b) that fault zones, insofar as they provided egress for hydrothermal manifestations including mercury, served as "windows" or apertures through which to assess conditions in deeper parts of the hydrothermal system. Clearly mercury and thermal anomalies provide few data points for a regional assessment, and because of variable permeability in fault zones sampled at $15 \mathrm{~m}$ spacing mercury anomaly data might exhibit an undesired degree of variation. We decided therefore to look at the much more abundant mercury background data to see how they might represent leakage through relatively impermeable bedrock. We supposed that background would be higher over bedrock aquifers that conduct hotter waters at higher rates of flow. Lower background would represent areas underlain by rocks containing cooler, mercury-depleted waters and lower rates of flow. Moreover, we thought that mercury background might be relatively unaffected by depth to the source waters if such a system had achieved steady state over time. We supposed that areal mapping of mercury background might permit detection of geothermal aquifers, though we assumed also that unforeseen factors would probably make such an interpretation ambiguous at best.

We were surprised therefore that the contoured background data exhibited the high degree of coherence shown in figure E-3. It suggested the possibility of an aquifer within the Sepulcher structural low extending from the Roaring Mountain area to the Yellowstone River. It suggested separate, though possibly related, aquifers for Mammoth and Bear Creek thermal areas. It suggested aquifer termination in the Gardiner fault footwall, with a suggestion of continuity to a location close to the Gardiner travertine deposits. It also suggested aquifer continuity between La Duke and the Gardiner area. These points of agreement with our anomaly conceptual model and other field evidence are considered valuable initial support for a regional aquifer model that is similar to the empirical, structural model of Struhsacker (1976).

\section{$\underline{\text { Conclusions }}$}

Soil-mercury and streambed-thermal anomalies are most useful in locating faults that intersect geothermal aquifers at depth. In some areas mercury-anomaly amplitude appears to reasonably represent aquifer conditions by reflecting mercury depletion along flow lines. In other areas, variable permeability along fault zones may compromise the use of anomaly data except as they help in placing limits on aquifer conditions. In two areas of cool, lateral ground-water flow, mercury anomalies were seen to be displaced relative to warm convective plumes.

Assessment of soil-mercury background may offer greater potential in locating geothermal aquifers. By assuming relatively homogeneous diffusion in unfaulted areas, higher background concentrations may be showing us areas underlain by geothermal aquifers. Contoured background suggests a mercury source area near Norris, with transport beneath the Roaring Mountain Horseshoe Hill area within the Madison Group at shallow depth. Background minimums suggest that this aquifer is blocked near the caldera ring fracture east of Norris; by dikes associated with 
Eocene and late Quaternary intrusions at two locations to the north; and by structural barriers in the footwall blocks of the Gardiner and Lava Creek fault zones. The $30 \mathrm{ppb}$ background contour appears to delineate an aquifer complex that trends northward between Roaring Mountain and the north boundary area. One lobe may be associated with travertine deposits at Gardiner, and another strikes directly toward the Bear Creek Spring area. A 20 ppb lobe trends northward in the Yellowstone River Valley near Little Trail Creek and may extend beyond the La Duke area. Another $20 \mathrm{ppb}$ lobe enters Mammoth from the Terrace Mountain area. The interpretation that mercury-background contours define an aquifer in the Sepulcher structural low east of the Gallatin Range must be viewed as a conceptual model at this point. Further testing is desirable, and this will include additional sampling in remote areas.

The existence of correlated mercury and thermal anomalies at the north boundary, however, argues strongly for one or more geothermal aquifers tapped by faults at these locations. We draw attention to the Gardiner airport and Reese Creek confluence anomalies in particular. At these locations the boundary of Yellowstone National Park is at the high-water mark on the southwest bank of the Yellowstone River. Weak thermal anomalies were located north of this line, outside the boundary. Following our results at Hot River and Chinese Garden, we associate these anomalies with nearby mercury anomalies inside the park. Deep geothermal transport across the boundary in aquifers at those locations is considered possible albeit mercury background indicated that the waters are depleted in mercury in those areas, and surface expressions have normal ground-water temperatures between Reese Creek and the Gardiner airport area. The chemistry changes in the municipal well water suggest that ground-water chemistry may be influenced by deep aquifer losses in the valley, even though solute concentrations in shallow ground water in this area are significantly less than those in thermal spring and well waters at La Duke Hot Spring and Mammoth Hot Springs.

Geothermal waters in the KGRA at La Duke may be more closely associated with the west side of the Sepulcher structural low, while those at Bear Creek may be associated with the east side of that structure. We conclude that the northernmost known thermal springs in the study area within Yellowstone National Park, those at Chinese Garden, are more susceptible to geothermal development in the eastem part of the KGRA. This applies also to the inferred thermal spring in the bed of the Yellowstone River immediately downstream from Bear Creek.

\section{Acknowledgments}

We thank the following people who gave freely of their time in field and laboratory work as National Park Service Volunteers: M. Ford, I. Blackie, S. Baum, J. Chadwick, J. Hamilton, J. Lewis, D. Chan, B. Kaeding, R. Van Horn, and M. Klukas. We also thank our National Park Service coworkers: A. Bailey, P. Conn, J. Hudgings, E. Colvard, and K. Adams. R. Kroneman (University of Utah Research Institute) offered valuable suggestions and T. Fries (U.S. Geological Survey) did the comparative cold vapor AAS analyses. 


\section{$\underline{\text { References Cited }}$}

Bougan, S. J., 1984, Soil mercury anomalies at Mud Volcano, Yellowstone National Park: (abstract) Yellowstone Physical Science Symposium, September 1984.

Capuano, R. M. and Bamford, R. W., 1978, Initial investigation of soil-mercury geochemistry as an aid to drill site selection in geothermal systems: Earth Sciences Laboratory, University of Utah Research Institute Report for Department of Energy Contract EG-78-C-07-1701, 33 p.

Colvard, E. M. and Hamilton, W. L., 1987, Investigations of soil mercury anomalies and radon in soil and water near mapped faults in northern Yellowstone National Park, Wyoming: (abstract) EOS Transactions American Geophysical Union, v. 68, no. 44, p. 1453.

Conn, P. J., Hudgings, J. A., and Hamilton, W. L., 1988, Mercury halo characterization of the northern Yellowstone hydrothermal system: (abstract) EOS Transactions American Geophysical Union, v. 69, no. 44, p. 1222.

Fraser, G. D., Waldrop, H. A., and Hyden, H. J., 1969, Geology of the Gardiner area, Park County, Montana: U.S. Geological Survey Bulletin 1277, 118 p.

Hamilton, W. L., Chambers, R. L., Colvard, E. M., and Hudgings, J. A., 1990a, Mercury anomalies associated with hydrothermal systems in the Norris-Mammoth-La Duke corridor and Mud Volcano: in and near Yellowstone National Park, WY and MT: Report 90-1, Yellowstone Physical Science Laboratory, Division of Research, National Park Service, Yellowstone National Park, 64 p.

Hamilton, W. L., Chambers, R. L., and Colvard, E. M., 1990b, Trends in mercury anomaly amplitude along faults within the Norris-Mammoth-La Duke corridor, in and adjacent to Yellowstone National Park, WY and MT: Transactions of the Geothermal Resources Council, v. 14, Part II, p. 1437-1443.

Phelps, D. and Buseck, P. R., 1978, Natural concentrations of $\mathrm{Hg}$ in the Yellowstone and Co geothermal fields: Geothermal Resources Council Transactions, v.2, p. 521-522.

Phelps, D. and Buseck, P. R., 1980, Distribution of soil mercury and the development of soil mercury anomalies in the Yellowstone geothermal area, Wyoming: Economic Geology, v. 75, p. $730-741$.

Struhsacker, E. M., 1976, Geothermal systems of the Corwin Springs-Gardiner area, Montana: possible structural and lithologic controls: MS Thesis, Montana State University, Bozeman, Montana, 93 p.

U.S. Geological Survey, 1972, Geologic Map of Yellowstone National Park: Miscellaneous Geologic Investigations Map I-711, 1 sheet $(1: 125,000)$.

Varekamp, J. C. and Buseck, P. R., 1983, Hg anomalies in soils: a geochemical exploration method for geothermal areas: Geothermics, v. 12, no. 1, p. 29-47.

Waldrop, H. A. and Hyden, H. J., 1963, Landslides near Gardiner Montana, in Short papers in geology, hydrology, and topography: U.S. Geological Survey Professional Paper 450-E, p. E11-E14.

White, D. E., 1967, Mercury and base-metal deposits with associated thermal and mineral waters, in Barnes, H.L., ed., Geochemistry of hydrothermal ore deposits (1st ed.): New York, Holt, Rhinehart and Winston, p. 575-631.

Williams, S., 1985, Soil radon and elemental mercury distribution and relation to magmatic resurgence at Long Valley Caldera: Science, v. 229, p. 551-553. 


\title{
CHAPTER F
}

\section{GEOCHEMICAL INVESTIGATIONS OF HYDRAULIC CONNECTIONS BETWEEN THE CORWIN SPRINGS KNOWN GEOTHERMAL RESOURCES AREA AND ADJACENT PARTS OF YELLOWSTONE NATIONAL PARK}

\author{
By Yousif K. Kharaka, Robert H. Mariner, Thomas D. Bullen, \\ B. Mack Kennedy ${ }^{1}$ and Neil C. Sturchio ${ }^{2}$
}

U.S. Geological Survey, 345 Middlefield Road, Menlo Park, CA 94025

(1) University of California, Berkeley, CA 94720

(2) Argonne National Laboratory, Argonne, IL 60439

\section{Contents}

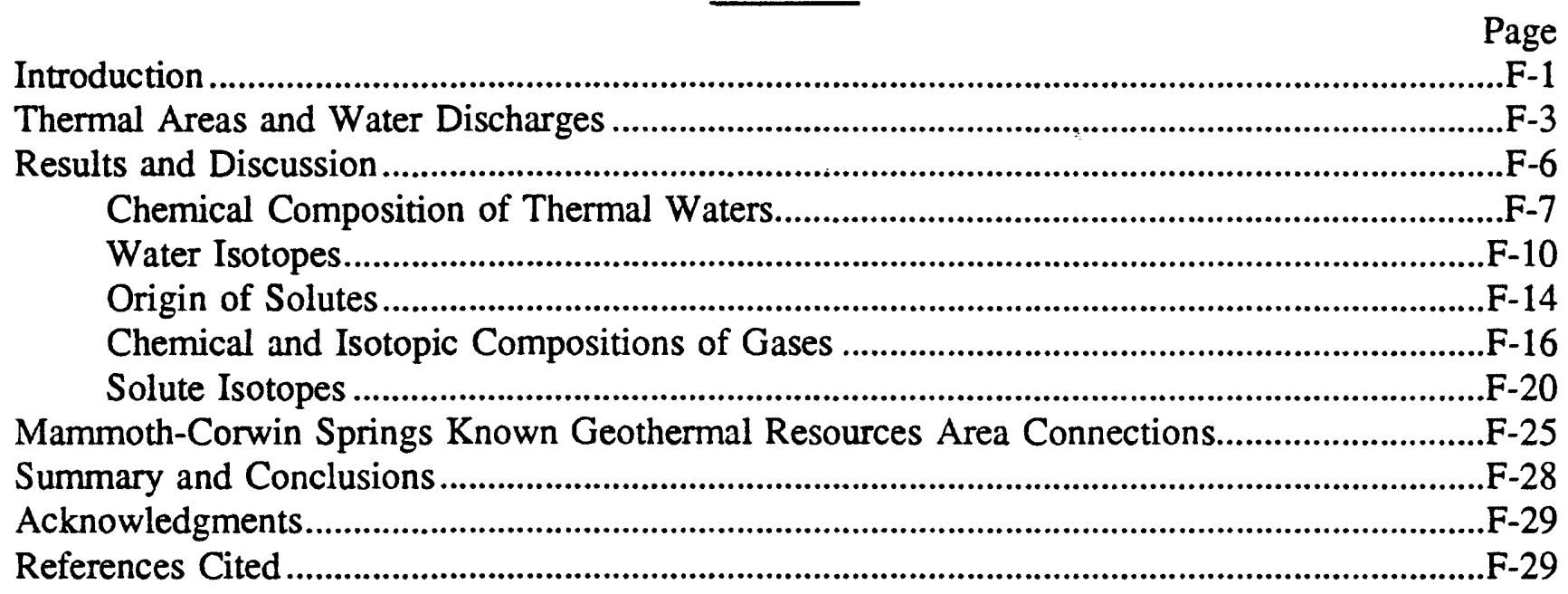

\section{Introduction}

In these investigations, geochemical data are examined with the objective of defining possible hydraulic connections between the Corwin Springs Known Geothermal Resources Area (KGRA) and adjacent locations in Yellowstone National Park, especially Mammoth Hot Springs. These data consist of the chemical and isotopic compositions of thermal and cold waters and rocks in the Corwin Springs KGRA and in the Norris-Mammoth area of the Park (fig. F-1). The concentrations and isotopic ratios of reactive and conservative soiutes are determined primarily by temperature controlled water-rock interactions and by mixing of fluids having different compositions. The concentrations and isotopic ratios of reactive solutes, such as $\mathrm{SO}_{4}, \mathrm{HCO}_{3}, \mathrm{Sr}$, and $\mathrm{Ra}$, are readily modified by the various processes of water-rock interaction, including dissolution and precipitation of minerals, mineral transformations, and ion exchange on the surfaces of clay minerals (Hem, 1985). The measured concentrations and isotopic ratios for these solutes are useful primarily as indicators of possible flow paths and the last rocks with which the water had reacted.

Conservative solutes, on the other hand, are considered so inert to water-rock interactions that their concentrations, relative proportions to each other, and isotopic ratios remain relatively constant. 


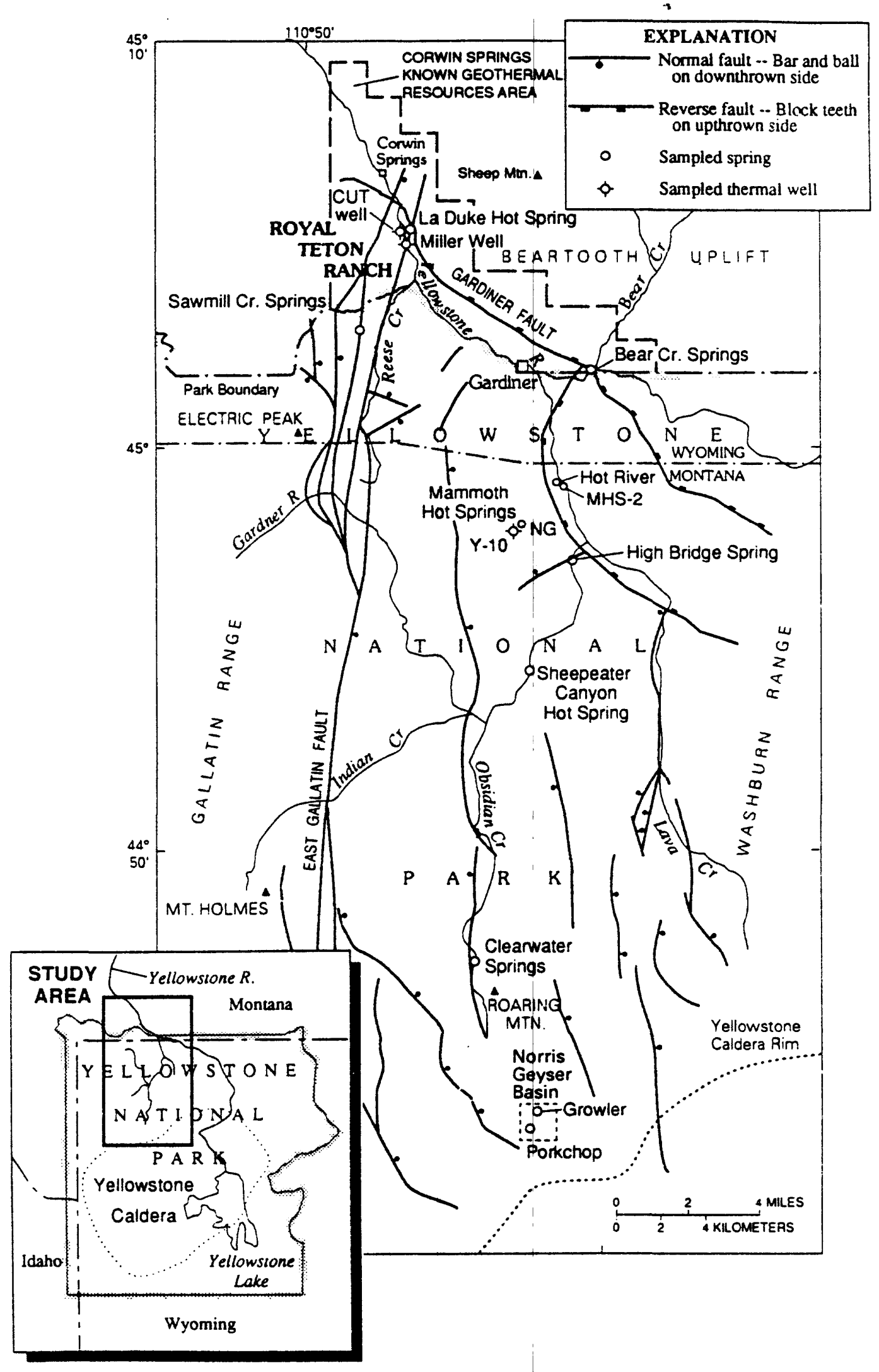

Figure F-1. Regional setting for the Corwin Springs Known Geothermal Resources Area Yellowstone National Park study area showing selected springs and wells, and principal geologic structures from Pierce and others (fig. C-1, this volume). Features shown in the Mammoth Hot Springs area include well Y-10 and Narrow Gauge spring (NG). 
Several of the most conservative solutes in the thermal waters of the study area, including $\mathrm{Cl}, \mathrm{Br}$, $\mathrm{B}$ and $\mathrm{He}$ are potentially diagnostic in identifying the origins of solutes and are particularly useful in calculating proportional mixing between mixed fluids (Ellis and Mahon, 1977). Concentrations and isotopic ratios of conservative solutes are, thus, the most useful geochemical data in investigating hydraulic connections between distant thermal sites. However, it is necessary to point out that results from even the most diagnostic geochemical data are not conclusive and, under optimal field conditions, each is subject to analytical and other uncertainties of up to \pm 10 percent.

Field investigations were conducted in 1988 through 1990 to obtain samples for detailed chemical (about 20 components) and stable and radioactive isotopic analyses of thermal waters, solutes (isotopes of $\mathrm{C}, \mathrm{S}, \mathrm{Sr}, \mathrm{B}, \mathrm{Li}, \mathrm{Pb}, \mathrm{Nd}, \mathrm{Ra}$ and $\mathrm{U}$ ) and noble and other gases from about 30 sites. The sampling sites are located mainly in the Mammoth Hot Springs area and Corwin Springs KGRA (fig. F-1), but extend from Norris Geyser Basin on the south to Chico Hot Spring on the north (28 km north of La Duke Hot Spring). Samples were obtained also from about 100 cold springs, seeps, and shallow ground-water wells for water isotope and major chemical analyses. These cold-water sites are located mainly north of the Mammoth Hot Springs area in the Beartooth uplift and the Gallatin Range, but also in areas to the east and west of Yellowstone National Park. Finally, about 40 rock and travertine samples were obtained for chemical and isotopic analyses.

An extensive geochemical data base has been obtained for this study in order to understand the origins and evolutions of waters in the study area. In this report, the chemical and isotopic compositions of thermal waters, solutes and gases are summarized, emphasizing the results that are pertinent to investigating possible hydraulic connections between the Corwin Springs KGRA and adjacent areas of Yellowstone National Park. The isotopic composition of thermal and cold springs are studied to determine the origin and possible recharge elevations of the thermal waters. Finally, concentrations and isotopes of the most conservative solutes and water isotopes are used in mass balance equations to estimate the possible amounts of Mammoth-type water in La Duke Hot Spring and Bear Creek Springs. The geochemical data indicate that (1) the thermal waters from the La Duke area of the Corwin Springs KGRA have evolved by reactions with rocks having some chemical and isotopic characteristics that are different from those encountered by Mammoth water and, subject to \pm 5 percent uncertainty, no thermal water from the Mammoth system is detected in this area of KGRA; and (2) a small component (10 \pm 10 percent) of water in the Bear Creek Springs area of the KGRA might be derived from the Mammoth system.

\section{Thermal Areas and Water Discharges}

Thermal fluids discharge in the study area primarily at (from south to north) Norris Geyser Basin, Roaring Mountain, Clearwater Springs, Sheepeater Canyon Hot Spring, Mammoth Hot Springs, Hot River, Bear Creek Springs and La Duke Hot Spring (fig. F-1). Each of these thermal areas is located within the Norris-Mammoth corridor, as delineated by Pierce and others (fig. C-4, this volume), and is related in some way to either northward-trending normal faults or northwesttrending reverse faults (fig. F-1). The geologic setting and geophysical characteristics of the NorrisMammoth corridor are described in this volume by Pierce and others, and Stanley and others, respectively. Rates of thermal-water discharge at each area noted above, as well as the general hydrology of the study area, are reported by Sorey and others (this volume). 
Previous geochemical studies have focused on thermal waters and rocks inside Yellowstone National Park (see Fournier, 1989, and Hildreth and others, 1991, for comprehensive reviews and numerous references). The chemical and, to a lesser extent, the isotopic compositions of thermal waters from the Norris-Mammoth area of the Park have been discussed by Gooch and Whitfield (1888), followed by Allen and Day (1935), Friedman (1970), Rowe and others (1973), Thompson and others (1975), Truesdell and others (1977), Kennedy and others (1985), White and others (1988), and Fournier (1989). Geochemical data on thermal springs in the Corwin Springs KGRA are sparse, but some chemical and water-isotope data from La Duke Hot Spring were reported by Mariner and others (1976), and Leonard and others (1978).

Samples for chemical and isotopic analyses were collected at each of the thermal areas noted above. In most areas, more than one site was sampled to assess the spatial variations in chemical and isotopic characteristics. About 10 of the important sites throughout the study area were sampled from two to four separate times to assess the temporal variability of their chemical and isotopic characteristics. In the case of thermal springs, the important sites were selected primarily because they had the highest temperatures and discharge rates of the thermal springs in the area. They were selected also because they were located at high elevations, preferably on local ridges or mounds in order to minimize mixing from local meteoric water and thermal seeps in the area.

At the south end of the study area, Norris Geyser Basin, located outside the northwest rim of the 600,000-year-old Yellowstone caldera, contains the widest diversity of hydrothermal activity known in the Park (White and others, 1988). The source of heat for this hydrothermal activity is clearly magmatic, but the water is meteoric, originating in the Gallatin Range and/or Beartooth uplift located north and northwest of the caldera (Truesdell and others, 1977; Fournier, 1989; Kharaka and others, 1990). At Norris Geyser Basin, fluid samples were collected from Porkchop Geyser and the nearby Porkchop spring located in Back Basin, and from Growler Spring located in Porcelain Basin (fig. F-1). North of Norris, one steam vent at Roaring Mountain was sampled for gases, three springs were sampled at Clearwater Springs, and one spring was sampled at Sheepeater Canyon Hot Spring (also referred to as Sheepeater Spring).

The highest total thermal discharges in the study area are at Mammoth, where thermal water (temperature $573^{\circ} \mathrm{C}$ ) issues from nearly 100 springs scattered over a score of steplike travertine terraces; travertine ages range from present to more than 400,000 years (Bargar, 1978; Sturchio, 1990; Pierce and others, this volume). Tracer and other chemical tests discussed by Sorey and others (this volume) show that the main part of the thermal discharge from the Mammoth hydrothermal system ultimately emerges in Hot River located about $1.5 \mathrm{~km}$ northeast of Mammoth Hot Springs (fig. F-2). The calculated amount of thermal water from the Mammoth system entering the Gardner River via Hot River, Mammoth Outflow, and the numerous known and unknown springs and seeps along the river averaged $590 \pm 30 \mathrm{~L} / \mathrm{s}$ during our study (Sorey and others, this volume). In addition to the $\mathrm{Y}-10$ well and the Hot River vent, about 10 thermal springs, including Narrow Gauge, Opal Terrace, High Bridge Spring and Mammoth Hot Springs-2 (MHS-2), were sampled in the Mammoth area (fig. F-2). Because of their geochemical and hydrologic importance, several sites, including the Y-10 well, Narrow Gauge, Opal Terrace, Hot River and MHS-2, were sampled up to four separate times.

Two main areas of visible thermal discharges occur in the Corwin Springs KGRA, and sites 


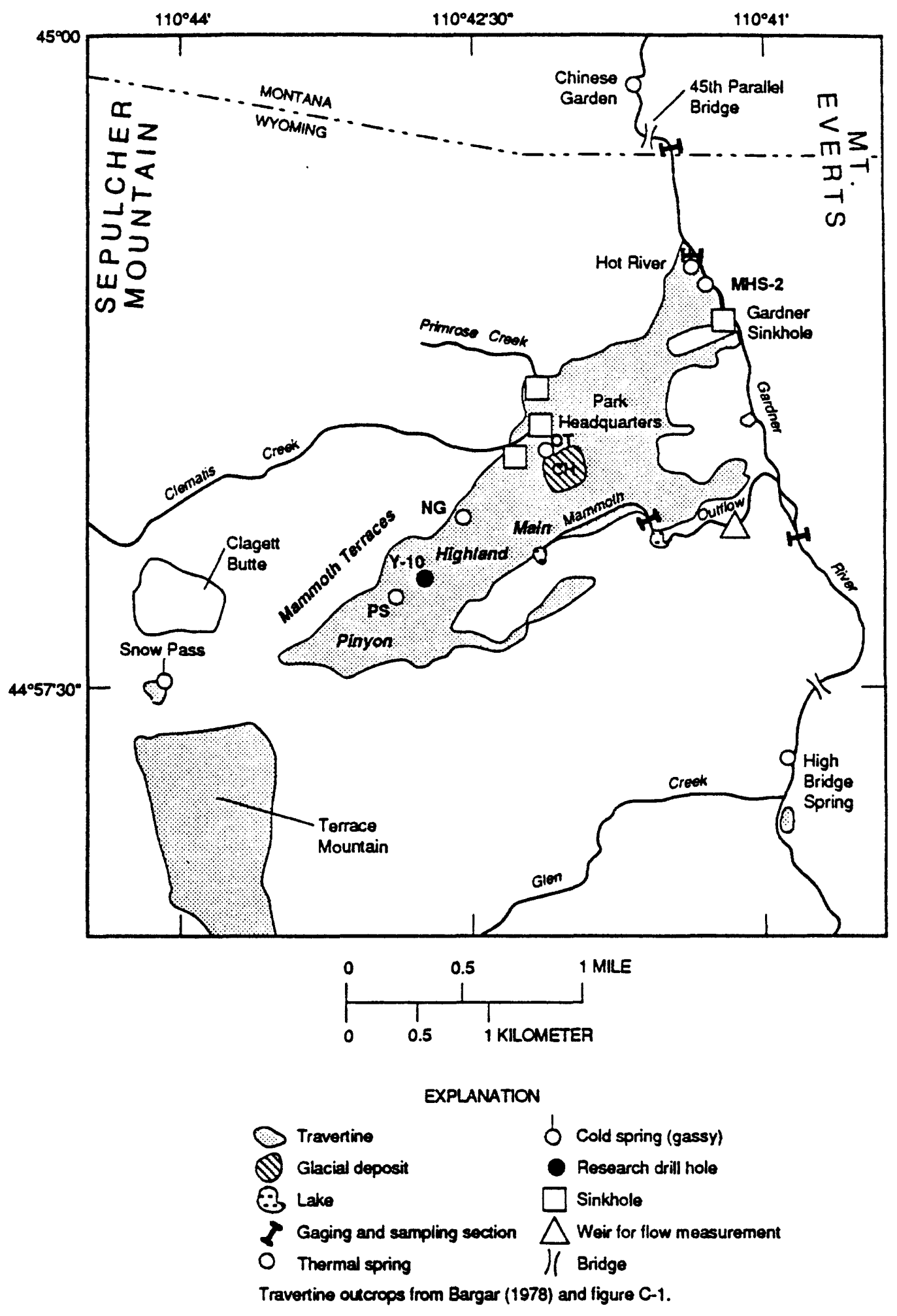

Figure F-2. Mammoth Hot Springs area in Yellowstone National Park showing the distribution of travertine deposits and the locations of well Y-10, selected thermal springs including Narrow Gauge (NG), Opal Terrace (OT), Poison Spring (PS), and Mammoth Hot Spring-2 (MHS-2), and sampling sites in the Mammoth Hot Springs - Gardner River area. 
there and in the Park were sampled extensively and up to four separate times (fig. F-1). The first area includes La Duke Hot Spring and an adjacent thermal seep, and thermal springs and seeps at river level within distances of about $1 \mathrm{~km}$ upstream and downstream from La Duke. The geothermal well drilled by the Church Universal and Triumphant (CUT), and the Miller thermal well are also located in this area (fig. F-1). The main visible discharge in this area, which lacks significant travertine deposits, is from La Duke Hot Spring (temperature $=68^{\circ} \mathrm{C}$ ) with a rate that ranged from 5 to $9 \mathrm{~L} / \mathrm{s}$ in 1988-90. For this area, calculations based on the increase in $\mathrm{SO}_{4}$ concentrations in Yellowstone River give much higher total discharge values that range from 49 to $67 \mathrm{~L} / \mathrm{s}$ (Sorey and others, this volume).

The second area of visible thermal discharges is at Bear Creek Springs area, located at the confluence of Bear Creek and Yellowstone River (fig. F-1). The main visible discharge in this area, which has extensive travertine deposits, is from the Bear Creek-1 vent (see fig. G-10, Sorey and others, this volume) with about $2 \mathrm{~L} / \mathrm{s}$ of thermal water (temperature $=32^{\circ} \mathrm{C}$ ). The Bear Creek-2 thermal field consists of many seeps and several springs with low discharges, including the Bear Creek-2 spring, which had a temperature of $33^{\circ} \mathrm{C}$; total thermal discharge from this field was visually estimated at 3-6 L/s. The Bear Creek-3 spring is located about $300 \mathrm{~m}$ to the west of Bear Creek-2 spring and outside the travertine deposits of the area. Bear Creek-3, with a temperature range of $15^{\circ}$ to $20^{\circ} \mathrm{C}$, issues from fractured Cretaceous shales and sandstones; the total discharge from the Bear Creek-3 field is $<1 \mathrm{~L} / \mathrm{s}$. The total thermal water discharged into Yellowstone River from the Bear Creek Springs area is estimated at about $17 \mathrm{~L} / \mathrm{s}$ (Sorey and others, this volume).

\section{$\underline{\text { Results and Discussion }}$}

The chemical and isotopic compositions of water from selected thermal springs and wells in and adjacent to the Norris-Mammoth corridor, including the Corwin Springs KGRA, are shown in tables F-1 and F-2, respectively. The chemical compositions of dissolved gases and of gas discharges are given in tables F-3 and F-4, respectively. Finally, the isotopic compositions for selected rock, travertine and mineral samples from the study area are shown in table F-5. Solute concentrations (table F-1) carry analytical errors of \pm 1 - 5 percent; gas concentrations (tables F-3 and F-4) are subject to errors of \pm 5 percent. Analytical uncertainties for isotope values are variable and are discussed in the relevant sections below. A few miscellaneous samples (tables F-1 to F-4) are from cold springs (for example, Sawmill Creek and Snow Pass, shown in figures F-1 and F-2, respectively); others are from thermal springs that are located outside the immediate area of this study (for example, Chico Hot Spring). The miscellaneous samples were selected either because they have high gas content and/or because they are important in understanding the regional evolution of fluids.

Concentrations of solutes (table F-1) were used to estimate the subsurface temperatures of last equilibration with aquifer rocks for the thermal waters of the important sites in the study area (table F-6). Only the results from the useful chemical geothermometers (Fournier, 1981; Giggenbach and others, 1983; Kharaka and Mariner, 1989), and from assuming the thermal water to be in equilibrium with anhydrite are shown in table F-6. Results show that the subsurface temperatures of the thermal waters from Norris Geyser Basin are about $300^{\circ} \mathrm{C}$, approaching the value of $360^{\circ} \mathrm{C}$ reported by Fournier (1989) as the maximum temperature obtained for the deep water inside the Yellowstone caldera. Subsurface temperatures of thermal waters decrease northward along the 
Norris-Mammoth corridor, declining to a value of about $100^{\circ} \mathrm{C}$ at Mammoth Hot Springs and values of about $80^{\circ}$ to $70^{\circ} \mathrm{C}$ at the Corwin Springs KGRA (table F-6).

Abundances of a variety of isotopes, stable and radioactive, were determined for this study and are reported using different notations and terminology (tables F-2 and F-5). Most of the notations used in this report are straightforward, but the interested reader is referred to Faure (1986) for details on terminology as well as the principles of isotope geochemistry. Practical isotope values are generally obtained by comparing the isotopic ratio of the sample with that of an accepted standard. In the case of He isotopes, the accepted standard is the atmosphere, and the values are reported as R/RA given by:

$$
\mathrm{R} / \mathrm{RA}=\frac{\left({ }^{3} \mathrm{He} / \mathrm{He}\right) \text { sample }}{\left({ }^{3} \mathrm{He} /{ }^{4} \mathrm{He}\right) \text { atmosphere }}
$$

Most of the other isotopes are reported in $\delta$ - values that are expressed in parts per thousand (permil, $\%$ ). In the case of oxygen isotopes, for example, the equation is:

$$
\delta^{18} \mathrm{O}=\left[\frac{\left({ }^{18} \mathrm{O} /{ }^{16} \mathrm{O}\right) \text { sample }}{\left({ }^{18} \mathrm{O} /{ }^{16} \mathrm{O}\right) \text { SMOW }}-1\right] \times 10^{3},
$$

where SMOW is the Standard Mean Ocean Water. In the case of Nd isotopes, the values are reported in epsilon $\left(\epsilon_{\mathrm{Nd}}\right)$ notation given by:

$$
\epsilon_{\mathrm{Nd}}=\left[\frac{\left({ }^{143} \mathrm{Nd} /{ }^{144} \mathrm{Nd}\right) \text { sample }}{\left({ }^{143} \mathrm{Nd} /{ }^{144} \mathrm{Nd}\right) \mathrm{CHUR}}-1\right] \times 10^{4},
$$

where CHUR stands for "chondritic uniform reservoir."

\section{Chemical Composition of Thermal Waters}

The salinity of thermal water for the three samples from Norris Geyser Basin ranges from about 1,500 to $2,000 \mathrm{mg} / \mathrm{L}$ dissolved solids. The water is high in $\mathrm{SiO}_{2}$ and is a $\mathrm{Na}-\mathrm{K}-\mathrm{Cl}$ type (cations with concentrations $\geq 5$ percent of total dissolved solids are listed in order of decreasing abundances and are followed similarly by anions) with relatively high concentrations of $\mathrm{Li}$ and $\mathrm{B}$ (fig. F-3), but very low concentrations of $\mathrm{Ca}, \mathrm{Mg}$ (fig. F-4) and other alkaline earth metals (table $\mathrm{F}-1$ ). Frequent sampling and $\mathrm{Cl}$ and $\mathrm{SO}_{4}$ determinations in waters from several springs were used by Fournier (1989; oral communication, 1991) to show that the concentration of $\mathrm{Cl}$ in the deep and unmodified thermal water from Norris Geyser Basin is about $550 \mathrm{mg} / \mathrm{L}$; this $\mathrm{Cl}$ value would indicate that the three samples from Norris (table F-1) have been concentrated by boiling from about 10 to 30 percent.

The salinity of water from Clearwater-3C is about $1,300 \mathrm{mg} / \mathrm{L}$, and the water type is similar to that of the Norris samples (fig. F-4). Clearwater-1 and -2 have lower salinities than Clearwater- 

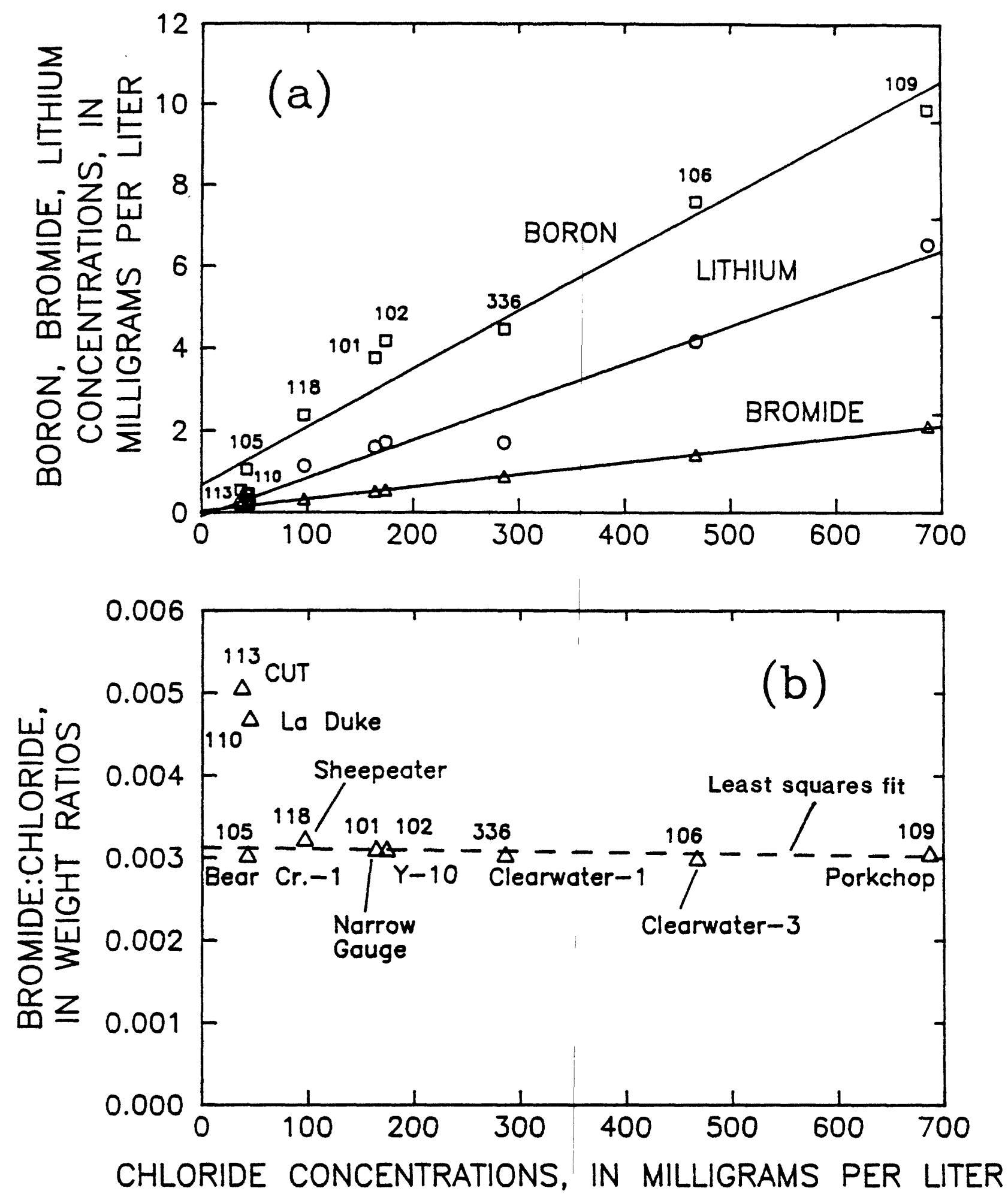

Figure F-3. Concentration of boron, bromide, and lithium (a), and the bromide to chloride weight ratios (b) as a function of chloride concentrations in the thermal waters from the study area. Numbers used for each feature correspond to sample numbers listed in table F-1. These are the most conservative chemical constituents in the thermal waters from Yellowstone National Park, and, as such, are used to indicate proportional mixing between waters of different origin. Note that the bromide to chloride ratios in samples from the La Duke area (La Duke and CUT) are significantly different than those from Bear Creek-1 and Yellowstone National Park. 

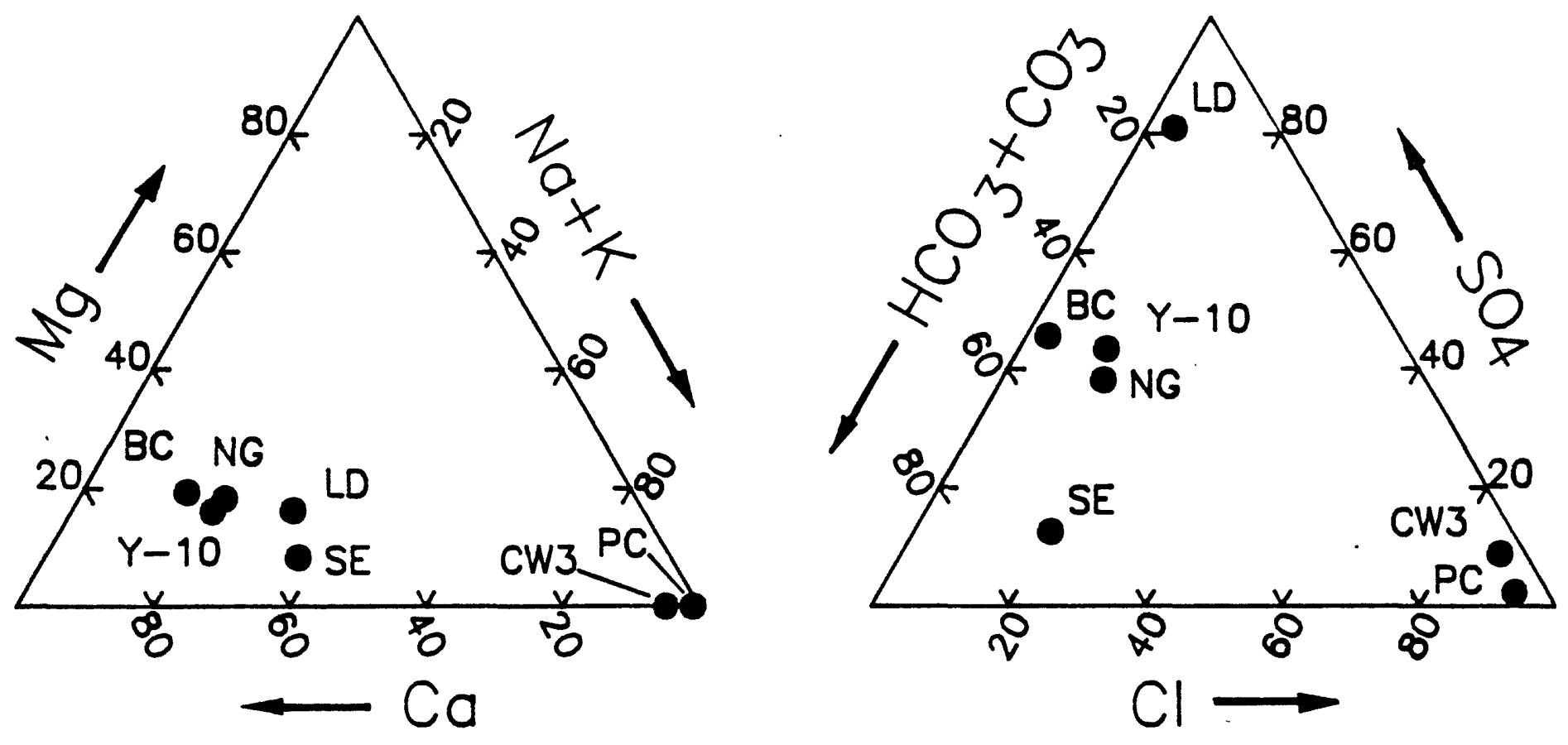

PERCENTAGE OF TOTAL MILLIEQUIVALENTS PER LITER

Figure F-4. Trilinear diagrams showing the percentage proportions of major cations and anions (proportions based on concentrations in milliequivalents per liter) in seven thermal springs from the study area. These diagrams indicate the general trend of increases in the proportions of $\mathrm{Ca}, \mathrm{Mg}, \mathrm{SO}_{4}$, and $\mathrm{HCO}_{3}+\mathrm{CO}_{2}$ and decreases in those of $\mathrm{Na}+\mathrm{K}$ and $\mathrm{Cl}$ from south to north, starting from Norris Basin (Porkchop, PC) and Clearwater-3C (CW3) through Sheepeater Spring (SE), then the Y-10 well and Narrow Gauge (NG) in the Mammoth area and finally, Bear Creek-1 (BC) and La Duke Hot Spring (LD) in the Corwin Springs Known Geothermal Resources Area. 
$3 \mathrm{C}$ because they are diluted by local meteoric water as indicated by the activity of tritium (19.4 TU in Clearwater-2) and by examination of the $\mathrm{Cl}-\delta \mathrm{D}$ relation for the samples of the area. The salinity of water from Sheepeater Spring is comparable to that of Clearwater-3C, but the water has much lower concentrations of $\mathrm{Cl}, \mathrm{Na}$, and $\mathrm{B}$, and higher concentrations of $\mathrm{Ca}, \mathrm{Mg}$, and $\mathrm{HCO}_{3}$.

The salinity of water from Mammoth Hot Springs (table F-1) is higher than that of unmodified water from Norris, Clearwater Springs, or Sheepeater Spring as it ranges from 2,000 to 3,000 mg/L dissolved solids. The water also is radically different in chemical composition from that of Norris or Clearwater Springs as it is much higher in $\mathrm{HCO}_{3}, \mathrm{SO}_{4}, \mathrm{Ca}$ and $\mathrm{Mg}$, and lower in $\mathrm{Cl}$ and $\mathrm{Na}$ concentrations. The water from Mammoth Hot Springs is of $\mathrm{Ca}-\mathrm{Na}-\mathrm{Mg}-\mathrm{HCO}_{3}-\mathrm{SO}_{4}-\mathrm{Cl}$ type with several chemical characteristics that are similar to that of water from Sheepeater Spring (fig. F-4). There are small differences in the chemical composition of water from different terraces at Mammoth as a result of travertine deposition and addition of local meteoric water. Water from the Y-10 well, which probably is the least modified of the Mammoth samples, has the highest salinity $\left(\sim 3,000 \mathrm{mg} / \mathrm{L}\right.$ dissolved solids) and relatively higher $\mathrm{SO}_{4}$ and $\mathrm{Ca}$ concentrations. Tracer and other chemical tests discussed by Sorey and others (this volume) show that the water in Hot River and MHS-2 are from the Mammoth system. The water salinities are lower because Hot River is diluted by mixing with water from Gardner River and Clematis Creek; MHS-2 is diluted by water from Clematis Creek only. The salinity and $\mathrm{Cl}$ concentrations in water from High Bridge Spring is comparable to that of Mammoth Hot Springs, but the concentrations of $\mathrm{Na}$ and $\mathrm{HCO}_{3}$ are higher and those of $\mathrm{Ca}, \mathrm{SO}_{4}$, and $\mathrm{Mg}$ are lower.

The salinity and concentrations of major cations and anions, with the exception of $\mathrm{Cl}$, are comparable in the thermal waters from Corwin Springs KGRA and Mammoth Hot Springs (table F-1, fig. F-3 and fig. F-4). Water samples from La Duke Hot Spring, CUT and Miller wells and the seeps and thermal springs in the La Duke area are relatively uniform in chemical composition (table F-1). They range in salinity from 1,900 to $2,350 \mathrm{mg} / \mathrm{L}$ total dissolved solids, and are all $\mathrm{Ca}$ $\mathrm{Na}-\mathrm{SO}_{4}-\mathrm{HCO}_{3}$ type waters with relatively high $\mathrm{Mg}$ concentrations (fig. $\left.\mathrm{F}-4\right)$, but low $\mathrm{Cl}$ (36-45 $\mathrm{mg} / \mathrm{L}$ ), B and $\mathrm{Li}$ values (fig. F-3). In the Bear Creek area, the major cations and anions in water from Bear Creek-1 and 2 are similar, but show large differences from those in Bear Creek-3; however, the chloride concentrations are the same at about $43 \mathrm{mg} / \mathrm{L}$. The sample from Bear Creek1 , which has the highest thermal discharge, has a salinity of about $3,000 \mathrm{mg} / \mathrm{L}$ dissolved solids and is of $\mathrm{Ca}-\mathrm{Na}-\mathrm{HCO}_{3}-\mathrm{SO}_{4}$ type.

The salinity and chemical composition of water for the miscellaneous samples, as expected, are variable (table F-1). The sample from Sawmill Creek Spring, located on a segment of the Reese Creek fault system (fig. F-1), has a salinity of about $850 \mathrm{mg} / \mathrm{L}$ dissolved solids and the water is of $\mathrm{Na}-\mathrm{HCO}_{3}$ type. The sample from Chico Hot Spring, located $28 \mathrm{~km}$ north of La Duke Hot Spring in the Beartooth uplift, has a salinity of about $350 \mathrm{mg} / \mathrm{L}$ dissolved solids; the water is of $\mathrm{Na}-\mathrm{Ca}$ $\mathrm{HCO}_{3}-\mathrm{SO}_{4}$ type.

\section{Water Isotopes}

The $\delta D$ and $\delta^{18} \mathrm{O}$ values of waters, especially when combined with the concentrations of conservative solutes (for example $\mathrm{Cl}$ ) are the best geochemical indicators of the origins, recharge locations, and flow paths of subsurface waters (for review articles and many references, see 
Truesdell and Hulston, 1980; Kharaka and Carothers, 1986). The stable isotopes of water are useful tools because the relations governing their distribution in present-day surface and shallow ground waters of an area (the local meteoric water) as well as their modifications in aquifers are reasonably well known. In aquifers, the isotopes of meteoric water may be modified by evaporation and mixing at low temperatures and by mixing, boiling, and isotopic exchange with minerals at high temperatures.

The $\delta \mathrm{D}$ and $\delta^{18} \mathrm{O}$ values of waters from 30 thermal springs (table F-2) and more than 100 cold springs, seeps, and ground-water wells were determined. Tritium activities were determined for 12 thermal samples, mostly from Mammoth Hot Springs and the Corwin Springs KGRA (table F-2). The numerous cold water samples, mainly from the Gallatin Range and the Beartooth uplift, were collected in an attempt to establish the local meteoric water line and the possible recharge locations for the thermal waters of the study area. Data for cold water samples (discussed below) are not given here, but results show that the local meteoric water line $\left(\delta D=8.3 \times \delta^{18} O+15\right)$ is approximately coincident with that of the Global Meteoric Water Line of Craig (1961) (fig. 5, Kharaka and others, 1990). Results of $\delta D$ and $\delta^{18} \mathrm{O}$ values shown in table F-2 for La Duke Hot Spring, Bear Creek-1, the Y-10 well, Narrow Gauge, Opal Terrace and Clearwater-3C are averages of two to four samples collected during 1989-1990. For these sites, results of replicate sampling are constant within analytical errors of about $\pm 1 \%$ for $\delta \mathrm{D}$ and $0.2 \%$ for $\delta^{18} \mathrm{O}$ values.

The $\delta \mathrm{D}$ and $\delta^{18} \mathrm{O}$ values for selected thermal waters from Yellowstone National Park show $\delta \mathrm{D}$ and $\delta^{18} \mathrm{O}$ shifts relative to the meteoric water line (fig. F-5). The origins of isotopic shifts likely are different for each area of the Park. The shifts for the waters from Norris Geyser Basin (fig. F-5) relative to recharge waters with $\delta \mathrm{D}$ and $\delta^{18} \mathrm{O}$ values of about -150 and $-20 \%$, respectively, were shown to result mainly from boiling for the $\delta \mathrm{D}$ values and from boiling and isotopic exchange with aquifer minerals for the $\delta^{18} \mathrm{O}$ values (Truesdell and others, 1977). In addition to boiling, the isotopes of water from Clearwater Springs are modified by mixing with dilute local meteoric water with a $\delta \mathrm{D}$ value of about $-144 \%$; this mixing is indicated by examination of the $\mathrm{Cl}-\delta \mathrm{D}$ relations (not shown) of the waters.

The samples from Mammoth Hot Springs also show moderate isotopic shifts from the meteoric water line (table F-2 and fig. F-5). The three sites shown in figure F-5 (Narrow Gauge, Opal Terrace and the $Y-10$ well) were selected because the $\delta D$ and $\delta^{18} O$ values of their waters remained constant for the duration of the study. The sample from the Y-10 well likely is the least modified of those from the three sites and the most representative of the upflow thermal water for the Mammoth system. This conclusion is reached because the water in the $\mathrm{Y}-10$ well is at high pressure ( $\sim 4$ bars at ground level), is not affected by precipitation of travertine, and water isotope values are the same for water obtained at ground level and by downhole sampler from a depth of $53 \mathrm{~m}$. The $\delta D$ value of water from the $Y-10$ well $(-149 \%)$ is relatively close to a $\delta D$ value of $-151 \%$ estimated for the recharge waters for the Mammoth system from the $\mathrm{Cl}-\delta \mathrm{D}$ relations of thermal waters. The corresponding $\delta^{18} \mathrm{O}$ value for the recharge waters is $-20.1 \%$, which would result in a moderate $1.7 \%$ shift in the $\delta^{18} \mathrm{O}$ value of water from the $\mathrm{Y}-10$ well.

There are two possible explanations for the moderate $\delta^{18} \mathrm{O}$ shifts for the waters from the $\mathrm{Y}-10$ well and the other sites from Mammoth Hot Springs. The oxygen shift could be the result of isotopic exchange between water and aquifer minerals as the water flows from recharge points in 


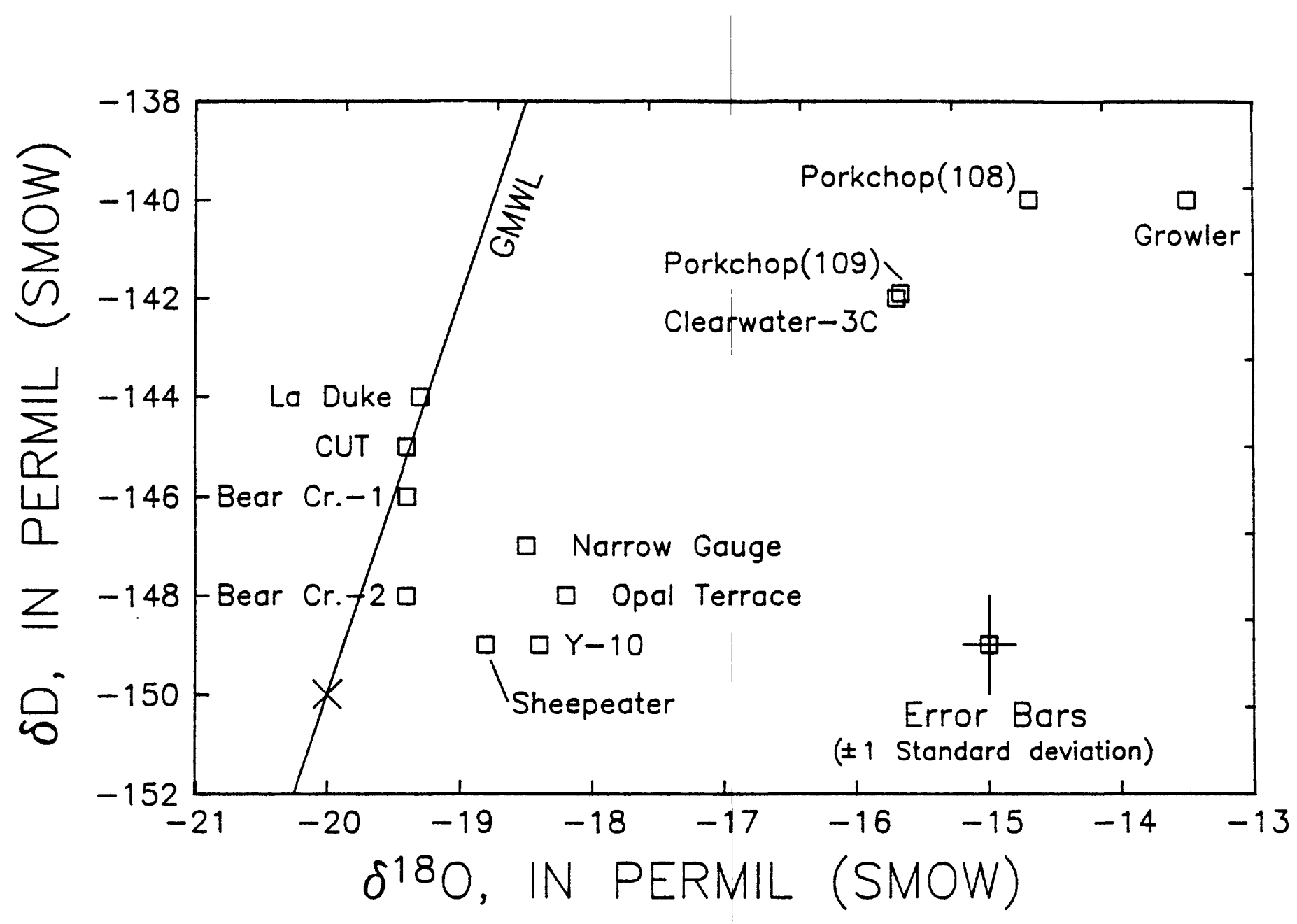

Figure F-5. The $\delta \mathrm{D}$ (deuterium) and $\delta^{18} \mathrm{O}$ (oxygen-18) values of selected thermal waters in the study area showing that the samples from the Corwin Springs Known Geothermal Resources Area (La Duke, CUT and Bear Creek-1) plot on or near the Global Meteoric Water Line (GMWL) of Craig (1961). The isotope values are reported relative to Standard Mean Ocean Water (SMOW). The (X) on the GMWL gives the $\delta \mathrm{D}$ and $\delta^{18} \mathrm{O}$ values of recharge water for the Norris Geyser Basin system calculated by Truesdell and others (1977). Numbers used to distinguish certain features correspond to sample numbers listed in table F-1. 
the Gallatin Range to the discharge sites at Mammoth. Oxygen exchange with calcite in Paleozoic limestones resulting in heavier oxygen isotopes in water is a possibility because isotopic exchange can take place between water and calcite at relatively low $\left(50^{\circ}\right.$ to $\left.100^{\circ} \mathrm{C}\right)$ temperatures (Clayton and others, 1966; Kharaka and Carothers, 1986; Plummer and others, 1990). Alternatively, the oxygen shift could also result from mixing of a Mammoth meteoric water with the deep and unmodified thermal water from Norris Geyser Basin. The minor $\delta D$ shifts (from a $\delta D$ value of about -151) can be explained by mixing, as in the case of oxygen isotopes, or they could result from minor evaporation of recharge water before it percolates deep in the subsurface. They could result also from hydrogen exchange with clay minerals in the sedimentary section (Kharaka and Carothers, 1986).

The $\delta \mathrm{D}$ and $\delta^{18} \mathrm{O}$ values of water from Corwin Springs KGRA show no or only minor isotopic shifts from the meteoric water line (fig. F-5). The samples from La Duke Hot Spring and the CUT well plot on the meteoric water line, indicating that the water cannot be obtained by proportional mixing of a significant amount of thermal water from the Mammoth system with local meteoric water. The absence of measurable oxygen isotope shift in these waters also can be used to indicate a relatively short residence time of water in limestone aquifers, because long residence times in such aquifers at the calculated subsurface temperature of about $80^{\circ} \mathrm{C}$ would be expected to result in a more significant oxygen isotope shift (Clayton and others, 1966; Kharaka and Carothers, 1986; Plummer and others, 1990). The residence time in limestone aquifers could be short in this system if the recharge takes place in the Beartooth uplift. In this model, water is in contact with Precambrian granitoids for relatively long periods during descent and lateral flow, and only in contact with limestones for shorter periods during ascent in the Gardiner fault. Isotopic exchange between water and silicate minerals is not likely at the low temperatures expected in this system (Truesdell and Hulston, 1980; Kharaka and Carothers, 1986). The differences in the $\delta D$ and $\delta^{18} O$ values of waters from the La Duke area and from Mammoth Hot Springs are an important indication that the two waters, even though both ultimately meteoric, are not isotopically related.

Thermal waters from Bear Creek-1 and -2 have exactly the same $\delta^{18} \mathrm{O}$ values and, within analytical error of $\pm 1 \%$, the same $\delta \mathrm{D}$ values (table F-2). Water from Bear Creek-3 (not plotted on fig. F-5) has $\delta \mathrm{D}$ and $\delta^{18} \mathrm{O}$ values of -160 and $-21.0 \%$, respectively. These values are much lighter isotopically than those from Bear Creek-1 and -2 , and together with differences in chemical composition indicate a different origin for Bear Creek-3 water, including possible recharge at much higher elevations. All the three samples from the Bear Creek Springs area plot close but slightly to the right of meteoric water line (fig. F-5). These relatively small isotopic shifts may be due largely to analytical errors; however, the shifts can be explained by isotopic exchange between water and sedimentary rocks as discussed for the Mammoth waters, or by mixing of a small component of thermal water from the Mammoth system with meteoric water of the area.

The concentrations of tritium in thermal waters from Bear Creek-1 in 1988-1990 ranged from 8 to 16 tritium units (TU), and a value of $10 \mathrm{TU}$ was measured in water from Bear Creek-2 (table F-2). These tritium values indicate that the thermal water from these springs contains $25-50$ percent ground water which is post 1960 in age. The thermal water from the La Duke area has no significant tritium, indicating that the water is older than about 100 years. The thermal water from Mammoth Hot Springs also has no significant tritium. The concentration of tritium in the sample from MHS-2, which is located on Gardner River close to Hot River (fig. F-2), is 2.5 TU. Tracer 
and other chemical tests, however, show that MHS-2 water is derived from the Mammoth system, but is diluted with meteoric water from Clematis Creek (Kharaka and others, 1990; Sorey and others, this volume).

A large number $(>100)$ of cold water samples were analyzed to investigate the distribution of $\delta \mathrm{D}$ and $\delta^{18} \mathrm{O}$ values of meteoric water in the study area and throughout Yellowstone National Park. The relevant conclusions are that (1) the Mammoth and Corwin Springs KGRA areas receive most of their meteoric water from winter storms that originate over the Pacific Ocean and move along the Snake River Plain, then diagonally towards Mammoth from the southwest corner of the Park; (2) Arctic fronts moving south and entering the area of study along the Yellowstone River (Dirks and Martner, 1982) have a small, but measurable effect on water isotopes; (3) there are no significant differences between the $\delta D$ and $\delta^{18} \mathrm{O}$ values of meteoric water from comparable elevations in the Gallatin Range and Beartooth uplift, and therefore water isotopes alone cannot be used to distinguish the specific recharge area for thermal water; (4) assuming present-day distribution of water isotopes, the estimated recharge elevations for the thermal water from the Mammoth area range from about 2,500 to 3,000 m; and (5) recharge elevations for the thermal water from the Corwin Springs KGRA, estimated from water isotopes alone and excluding water from Bear Creek-3, range from about 1,700 to $2,800 \mathrm{~m}$. The large range in estimated elevations is due to the fact that the springs are situated in a relatively narrow valley in a mountain terrain. In such topography, the $\delta \mathrm{D}$ and $\delta^{18} \mathrm{O}$ values of meteoric water are essentially constant because they are not affected significantly by local elevations of the valley.

\section{Origin of Solutes}

The origins of $\mathrm{SiO}_{2}$ and other dissolved species in the $\mathrm{Na}-\mathrm{K}-\mathrm{Cl}-\mathrm{SiO}_{2}$ type waters from Norris and other basins in the Park are reasonably well understood (Fournier, 1989; Kharaka and others, 1990). The concentrations of $\mathrm{SiO}_{2}$ are controlled by the solubility of quartz at the reservoir temperatures, and $\mathrm{Cl}, \mathrm{Na}$, and $\mathrm{K}$ are leached from the volcanic rocks. As pointed out by the pioneering work of Ellis and Mahon $(1964 ; 1967), \mathrm{Cl}$ concentrations in such waters are determined mainly by the $\mathrm{Cl}$ content of the volcanic rocks and the highest subsurface temperatures attained; the $\mathrm{Na}$ content of volcanic rocks is high and enough $\mathrm{Na}$ is leached to obtain a charge balance in the fluid phase. The concentrations of $\mathrm{SO}_{4}$ and $\mathrm{HCO}_{3}$ are generally low, mainly because of the low solubilities of $\mathrm{Ca}$ sulfate and carbonate minerals at the high reservoir temperatures (up to $360^{\circ} \mathrm{C}$ ). The concentrations of $\mathrm{HCO}_{3}$ and $\mathrm{Na}$ relative to $\mathrm{Cl}$ are increased in some thermal waters by the reactions of $\mathrm{CO}_{2}$ (from metamorphic, magmatic and other sources) with albite and/or obsidian to form clay minerals. The reaction of $\mathrm{CO}_{2}$ with albite to form a clay mineral can be represented by the unbalanced reaction

$$
\mathrm{CO}_{2}+\mathrm{H}_{2} \mathrm{O}+\text { albite }=\mathrm{Na}^{+}+\mathrm{HCO}_{3}^{-}+\text {clay }+\mathrm{H}_{4} \mathrm{SiO}_{4}{ }^{\circ}
$$

The concentrations of $\mathrm{B}, \mathrm{Li}$ (fig. $\mathrm{F}-3$ ), and $\mathrm{K}$ are relatively high as these elements are partitioned into water at high temperatures. The concentrations of $\mathrm{Mg}, \mathrm{Ca}, \mathrm{Sr}$ and other alkaline earth metals, on the other hand, are very low because these elements are partitioned into minerals at high temperatures. $\mathrm{Mg}$ enters chlorite and other clay minerals, and the solubilities of $\mathrm{Ca}$ and $\mathrm{Sr}$ carbonates and sulfates decrease rapidly at high temperatures. 
In Norris and other geyser basins within the Yellowstone caldera, boiling causes an increase in the concentrations of most dissolved species in the residual water. However, gases including $\mathrm{CO}_{2}, \mathrm{H}_{2} \mathrm{~S}$, He and, at high temperatures, some $\mathrm{H}_{3} \mathrm{BO}_{3}$ will partition into the steam phase; only traces of $\mathrm{Cl}$ and $\mathrm{SiO}_{2}$ will be carried by the steam. Oxidation of $\mathrm{H}_{2} \mathrm{~S}$ and $\mathrm{S}^{\circ}$ to $\mathrm{H}_{2} \mathrm{SO}_{4}$ in steam condensate close to the surface is responsible for acidic springs of low salinity and high $\mathrm{SO}_{4}$ concentrations relative to $\mathrm{Cl}$. The $\mathrm{S}$ isotope data (discussed below) show that oxidation of $\mathrm{H}_{2} \mathrm{~S}$ is also the principal source of $\mathrm{SO}_{4}$ in the undiluted thermal waters. However, the $\mathrm{Ph}$ of these waters remains close to neutral because the minor $\mathrm{H}_{2} \mathrm{SO}_{4}$ generated from oxidation of $\mathrm{H}_{2} \mathrm{~S}$ is buffered by other chemical reactions.

The chemical and isotopic compositions of water and solutes in Mammoth Hot Springs show a major component of thermal water that derives its heat and some solutes from a magmatic source. White and others (1988) postulated that the thermal water at Mammoth derives its heat and most of the conservative solutes including $\mathrm{Cl}, \mathrm{B}, \mathrm{Br}$, and $\mathrm{Li}$ from the same sources as the thermal water in Norris Geyser Basin. The lower concentrations of these conservative solutes in the Mammoth water (fig. F-3) can be explained by mixing about $30-40$ percent Norris water with $70-60$ percent low-salinity meteoric water, with mixing proportions determined mainly by the selected concentration of $\mathrm{Cl}$ in the Norris component. Kharaka and others (1990) presented an alternative model and postulated that about half of the volatiles including $\mathrm{He}$ and $\mathrm{CO}_{2}$ together with the heat for the Mammoth system are provided by a cooling magmatic body emplaced beneath the Mammoth area (see more details in the Chemical and Isotopic Compositions of Gases). In this model, the conservative solutes would be leached at temperatures that probably fall in the range of $100^{\circ}$ to $360^{\circ} \mathrm{C}$, mainly from Precambrian basement rocks because the thickness of the sedimentary section in the area is less than about $3 \mathrm{~km}$ (Pierce and others, this volume). The subsurface temperatures in aquifers in Precambrian rocks in the Mammoth system are difficult to estimate. Because the concentrations of $\mathrm{Cl}$ and other conservative solutes are lower in water from Mammoth Hot Springs compared with that from Norris Geyser Basin, the leaching temperatures at Mammoth are expected to be lower than the $360^{\circ} \mathrm{C}$ obtained at Norris, but higher than about $100^{\circ} \mathrm{C}$ calculated from chemical geothermometry (table F-3).

Relative to Norris Geyser Basin, the water from Mammoth Hot Springs has much higher concentrations of reactive (nonconservative) solutes including $\mathrm{HCO}_{3}, \mathrm{SO}_{4}, \mathrm{Ca}, \mathrm{Mg}$, and $\mathrm{Sr}$ (fig. F-4). These and other solutes, together with isotopes of $\mathrm{S}, \mathrm{C}$ and $\mathrm{Sr}$ (see Solute Isotopes), show that the water at Mammoth has also reacted with and has dissolved marine anhydrite, calcite and dolomite from the Paleozoic sedimentary section at subsurface temperatures of about $100^{\circ} \mathrm{C}$. This relatively low temperature interaction with the sedimentary section at Mammoth follows the high temperature water-rock interactions responsible for the relatively high concentrations of $\mathrm{Cl}$ and other conservative solutes.

The salinity and concentrations of major cations and anions in thermal water in the Corwin Springs KGRA are comparable to those of water in Mammoth Hot Springs (fig. F-4), although the concentrations of $\mathrm{Cl}$ and the conservative components are much lower (fig. F-3). The conservative and reactive chemical components in the thermal waters from the Corwin Springs KGRA can be abtained from one or a combination of two models. The first assumes a separate origin from that of water at Mammoth and involves reactions of meteoric water with Paleozoic sedimentary rocks at subsurface temperatures of about $80^{\circ} \mathrm{C}$ for water at the La Duke area, and about $70^{\circ} \mathrm{C}$ for that 
at the Bear Creek Springs area (table F-3), together with a possibility of reactions with Precambrian basement rocks.

The second model involves mixing of a thermal component from the Mammoth system with local meteoric water, as suggested by the concentrations of the most conservative solutes $\mathrm{Cl}, \mathrm{Br}, \mathrm{B}$, and $\mathrm{Li}$ (fig. F-3). The thermal component likely would have the chemical and isotopic compositions of present-day Mammoth thermal water; or it is possible that the thermal component could have the compositions of the deep water at Mammoth prior to acquiring most of the reactive solutes from interactions with limestones. Because mixing is based on the concentrations of conservative solutes, the mixing proportions calculated for the two possibilities would be approximately the same. Mixing is especially likely at Bear Creek Springs because concentrations of these conservative solutes give approximately the same ratio as that of thermal waters from the Norris-Mammoth area of the Park. However, mixing is less likely for waters from the La Duke Hot Spring area as the ratios of these solutes are significantly different from those of the Norris-Mammoth area (fig. F-3). Computer modeling using the geochemical code SOLMINEQ.88 (Kharaka and others, 1988) indicates that in addition to mixing 10 to 30 percent present-day Mammoth thermal water with dilute meteoric water, to obtain the concentrations of $\mathrm{Cl}$ and other conservative solutes, the mixed water would have to participate in several chemical reactions with sedimentary rocks in order to obtain the concentrations of $\mathrm{Ca}, \mathrm{SO}_{4}, \mathrm{HCO}_{3}$, and other reactive solutes. As indicated from the chemical geothermometry, the reactions take place at $70^{\circ}$ to $80^{\circ} \mathrm{C}$ and include dissolution of anhydrite, dedolomitization and exchange of $\mathrm{Ca}$ for $\mathrm{Na}$ on clay minerals. These reactions are geologically feasible and are thermodynamically possible. Nevertheless, even the mixing model based on conservative solutes allows only a maximum 20 percent component of a Mammoth-type water in the thermal waters from the Corwin Springs KGRA.

\section{Chemical and Isotopic Compositions of Gases}

The chemical compositions of gases dissolved in waters from selected springs in the study area are shown in table F-3. The chemical composition of gases from a fumarole at Roaring Mountain and gas phases from selected springs are shown in table F-4. A complete data set of the abundances and isotopic compositions of noble gases from these sites was obtained for this study because preliminary results (Kharaka and others, 1990) proved particularly useful in determining hydrologic connections in the study area. Data on noble gases are also used to calculate the original composition of gases for the samples that have degassed and/or have been contaminated with air. Except for the samples from the CUT and Miller wells, gas loss prior to sampling has affected the compositions listed in table F-3, including that of sample 90YNP-5 obtained from a depth of $53 \mathrm{~m}$ in the Y-10 well using a downhole sampler. Gas loss is prevalent in these samples mainly because the pressure of $\mathrm{CO}_{2}$ gas is very high (more than 5 bars in the Y-10 samples) resulting in gas separation in the subsurface.

In the Norris-Mammoth corridor, $\mathrm{CO}_{2}$ is the dominant gas, comprising 97 to more than 99 percent of the $\mathrm{H}_{2} \mathrm{O}$-free total (table $\mathrm{F}-4$ ), with $\mathrm{N}_{2}$ and $\mathrm{H}_{2} \mathrm{~S}$ being locally significant components. The composition of gas from Bear Creek-1 (table F-3) is generally similar to that of the Mammoth samples, and the pressure of $\mathrm{CO}_{2}$ gas is moderately high at about 1.0 bars. The total gas content and the proportion of $\mathrm{CO}_{2}$ (pressure of $\mathrm{CO}_{2}$ gas is about 0.2 bars) are lower in samples from the La Duke Spring area of the Corwin Springs KGRA. The samples from Chico Hot Spring and Sawmill 
Creek Spring (table F-4) have $\mathrm{N}_{2}$ concentrations expected in local ground water in equilibrium with air; the sample from Sawmill Creek Spring, however, has a relatively high concentration of $\mathrm{CH}_{4}$.

With the exception of He and in some cases ${ }^{40} \mathrm{Ar}$, the concentrations of noble gases in the recharge and thermal waters of the study area are those expected from equilibrium with air (Mazor and Fournier, 1973; Kennedy and others, 1985). Helium concentrations in excess of air-saturated water reflect the addition of magmatic and/or radiogenic He. The magnitude of excess He due to radiogenic sources will generally increase with increasing age of the water. The effect is most pronounced with He due to the paucity of $\mathrm{He}$ in air $(\sim 5.2 \mathrm{ppm})$ and air saturated water $(0.002$ $\mu \mathrm{m} / \mathrm{kg}$ ). The amount of radiogenic ${ }^{40} \mathrm{Ar}$ added, however, is minor relative to the atmospheric component in recharge water. The total Ar concentration in thermal water, therefore, is expected to remain relatively constant at about $15-16 \mu \mathrm{m} / \mathrm{kg}$; approximately the value obtained for water from the CUT and Miller wells (table F-3), reflecting the dominance of the atmospheric component.

The concentrations of $\mathrm{He}$ in the thermal waters from the La Duke Hot Spring area are relatively constant, ranging from 9.8 to $11.3 \mu \mathrm{m} / \mathrm{kg}$. The values are well constrained, as they are based on measured He concentration in undegassed samples from CUT and Miller wells and a calculated value $(9.8 \mu \mathrm{m} / \mathrm{kg}$ ) for a moderately degassed sample from La Duke Hot Spring (table F3). The measured concentrations of $\mathrm{He}$ in water samples from the $\mathrm{Y}-10$ well and other sites in the Mammoth area appear much lower than those from the CUT well and other samples from the La Duke Hot Spring area (table F-3). The calculated values for the undegassed water from the Y-10 well, however, range from about 4 to $10 \mu \mathrm{m} / \mathrm{kg}$ and are closer to the value of $11.3 \mu \mathrm{m} / \mathrm{kg}$ from the CUT well. The calculated range of He concentrations in water from the Y-10 well is based on a total of four gas samples, two obtained using downhole samplers and the others obtained at ground level. A value in the range of 2 to $10 \mu \mathrm{m} / \mathrm{kg}$ is calculated for sample 90YNP-5, obtained from a depth of $53 \mathrm{~m}$, and probably the most reliable of the analyzed gas samples. A value in the range of 4 to $17 \mu \mathrm{m} / \mathrm{kg}$ is calculated for sample $89 \mathrm{YNP}-102$ (table F-3) obtained at ground level. The lower $\mathrm{He}$ value for each sample is calculated assuming bulk stripping of $\mathrm{He}$ and $\mathrm{Ar}$ (loss proportional to concentrations); the higher value is based on a Rayleigh-type distillation where the loss of $\mathrm{He}$ and $\mathrm{Ar}$ are functions of their solubilities as well as concentrations. Helium and Ar loss by bulk stripping is more likely in the sample obtained at ground level because of the rapid rate of gas loss; loss by Rayleigh-type distillation is more likely with the downhole sample because the separating gas bubbles are likely to remain small and able to reequilibrate with the fluid. Extensive degassing and minor air contamination have affected the concentrations of noble gases from Bear Creek-1; the calculated He concentrations in water from Bear Creek-1 assuming bulk stripping are relatively low, ranging from about 0.3 to $1.0 \mu \mathrm{m} / \mathrm{kg}$.

The most important differences between the noble gases in thermal waters from the Corwin Springs KGRA and Mammoth Hot Springs are indicated by their isotopic compositions. Kennedy and others (1985) showed that all the noble gases from Yellowstone National Park can be explained by mixing of three distinct components. The first component is of magmatic (mantle) origin with ${ }^{3} \mathrm{He} / \mathrm{He} \sim 16$ times the air value (R/RA 16). The second component is of radiogenic origin (crustal) with a theoretical R/RA $<0.05$. The third component has the composition of air and originates from percolating meteoric water saturated with atmospheric gases $(R / R A=1)$. They also showed that all the Yellowstone gases plot in a relatively narrow planar field on a three dimensional $\mathrm{He}-\mathrm{Ar}$ correlation diagram (axes being ${ }^{3} \mathrm{He} /{ }^{40} \mathrm{Ar},{ }^{4} \mathrm{He} /{ }^{40} \mathrm{Ar}$, and ${ }^{36} \mathrm{Ar}{ }^{40} \mathrm{Ar}$ ). The samples from the 


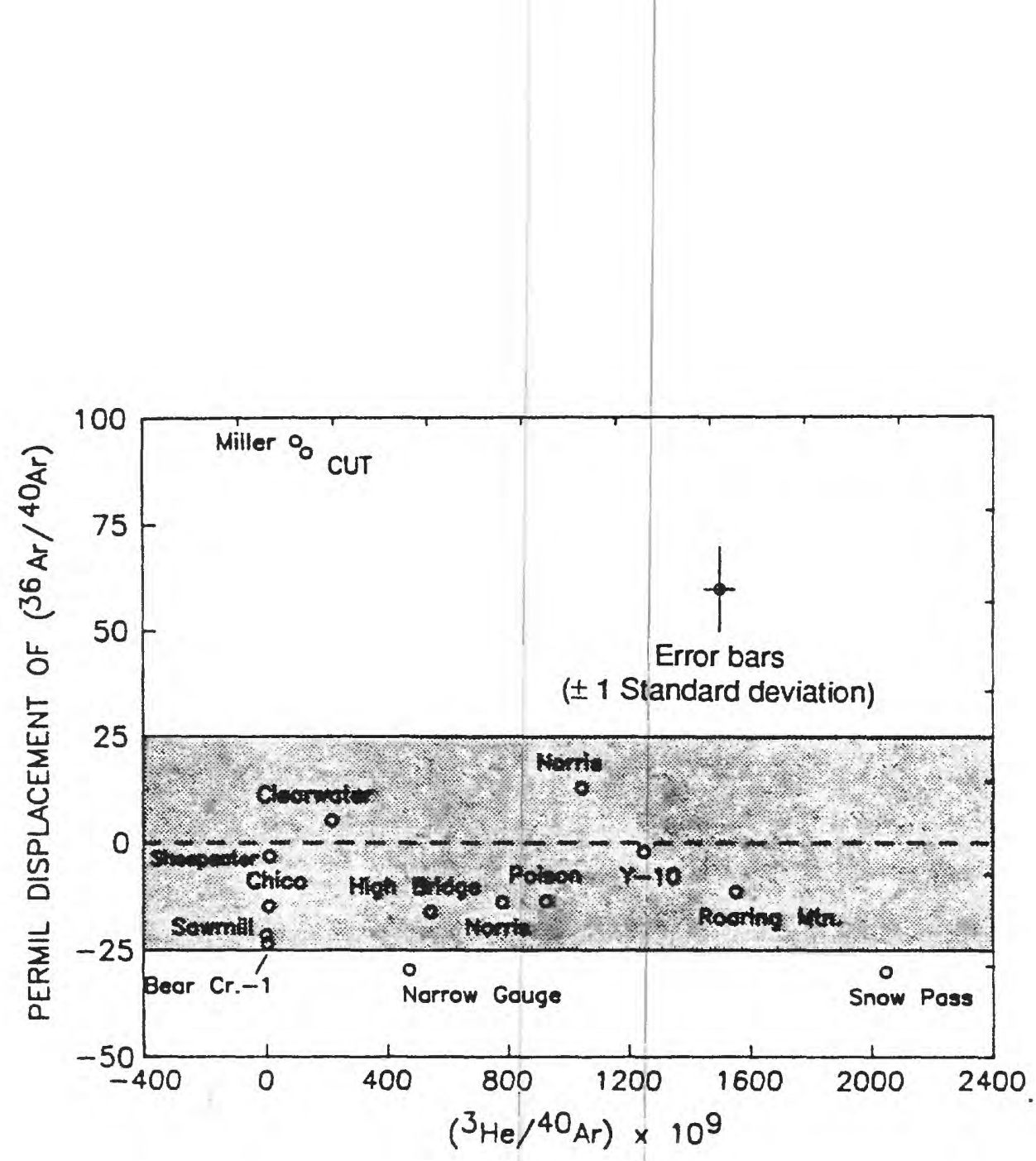

Figure F-6. The permil deviations in the ${ }^{36} \mathrm{Ar} /{ }^{40} \mathrm{Ar}$ (argon-36/argon-40) ratios of gas samples from the study area as a function of ${ }^{3} \mathrm{He}{ }^{40} \mathrm{Ar}$ ratios (helium-3/argon-40). Deviations (at the 2 standard deviation level) are relative to a planar surface encompassing all the data from Yellowstone National Park, on a three dimensional He-Ar isotope plot (Kennedy and others, 1985). Note that only the samples from the La Duke area (CUT and Miller wells) plot significantly away from the Yellowstone field. 
Mammoth area measured for this study as well as the sample from Bear Creek-1 also plot in or near this field. The samples from CUT and Miller wells, however, plot significantly outside the field for Yellowstone waters. The differences in the ${ }^{36} \mathrm{Ar} /{ }^{40} \mathrm{Ar}$ and ${ }^{3} \mathrm{He} /{ }^{40} \mathrm{Ar}$ ratios from CUT and Miller wells compared with samples from the Mammoth area and Bear Creek-1 are illustrated in figure F-6; the differences with other $\mathrm{He}$ - $\mathrm{Ar}$ isotopes are also major.

Results from this investigation show that Mammoth Hot Springs is an area of high gas discharge with up to 50 percent of $\mathrm{He}, \mathrm{CO}_{2}$, and possibly other gases being of mantle origin. The samples from the Y-10 well and three springs in its vicinity (table F-2) yield R/RA values up to 8.4, and the molar total $\mathrm{C} /{ }^{3} \mathrm{He}$ value of $5 \times 10^{9}$ obtained for $\mathrm{Y}-10$ is diagnostic of mantle gases (Des Marais, 1989). The ${ }^{3} \mathrm{He} / \mathrm{He}$ ratios relative to air are still very high $(\mathrm{R} / \mathrm{RA}=7.5)$ in the sample from Snow Pass located (fig. F-2) about $2 \mathrm{~km}$ west of $Y-10$, but the sample from High Bridge Spring ( -3 $\mathrm{km}$ southeast of $\mathrm{Y}-10$ ) has an R/RA value of only 1.2. Gases from Sheepeater Spring yield a relatively high $R / R A$ value of 5.8 , and because the water has many chemical and isotopic characteristics of Mammoth-type water, it is possible that the Mammoth hydrothermal system may extend as far south as Sheepeater Canyon. The uncertainty in the R/RA values is generally about 5 percent.

The ${ }^{3} \mathrm{He} / \mathrm{He}$ ratios in fluids at Norris Geyser Basin yield R/RA values that range from about 2 to 9, with the high values being comparable to those at Mammoth (Kennedy and others, 1985; Welhan, 1981). The ratios relative to air decrease to 2.2 and 3.0, respectively (table F-2) in fluids from Roaring Mountain and Clearwater Springs located north of Norris along the Norris-Mammoth corridor (fig. F-1). The overall pattern in He isotopic variations along the Norris-Mammoth corridor suggests a possibility for a source of magmatic volatiles (and heat) for the Mammoth system which is independent of the main Yellowstone system defined by the fluids within the caldera and at Norris. Defining the nature and exact location for this separate magmatic source (if it exists) will require additional investigations, but its location beneath Mammoth Hot Springs is suggested by the fact that the highest ${ }^{3} \mathrm{He} / \mathrm{He}$ ratios, gas discharges, and heat fluxes are obtained there (Kharaka and others, 1990). Geophysical evidence consistent with this source is provided by preliminary results from magnetotelluric soundings that indicate a high electrical-conductivity zone (probably at temperatures $>500^{\circ} \mathrm{C}$ ) at depths greater than $10 \mathrm{~km}$ beneath Mammoth Hot Springs (Stanley and others, this volume).

Samples from CUT and Miller wells and Bear Creek-1 have R/RA values of $0.13,0.11$, and 0.29 , respectively (table F-2). On the basis of a Yellowstone mantle value of R/RA $=16$ and local crustal values that range from 0.05 (Sawmill Creek Spring) to 0.24 (Chico Hot Spring), it is unlikely that more than 2 percent of He from Bear Creek-1 and 1 percent from the CUT and Miller wells could be of mantle origin.

The age of thermal water is an important parameter for understanding the flow path and evolution of water. The concentration of $\mathrm{He}$ in ground water together with the porosities and $U$ and Th contents of aquifer rocks is one of the few methods available to approximate the age of the water (Torgersen and Clarke, 1985). Modeling ${ }^{4} \mathrm{He}$ production using $\mathrm{U}$ and Th values and porosities (5 to 20 percent) for sedimentary rocks in the study area, and assuming no separate sources (outside the aquifer) for ${ }^{4} \mathrm{He}$, gave apparent ages on the order of $10^{5}-10^{7}$ years to produce the ${ }^{4} \mathrm{He}$ at CUT. A lower apparent age on the order of $10^{4}-10^{6}$ years can be calculated using a porosity of 1 percent 
and $U$ and the much higher Th data (2-3 ppm $U$ and 30-50 ppm Th) for the Beartooth batholith (Wooden and Mueller, 1988). On the basis of the same assumptions, the age of water at Bear Creek-1 would be lower by a factor of 10 to 40 than the age of water at the CUT well. Note that tritium values in Bear Creek-1 indicate that 25 to 50 percent of water is post 1960 . Assuming that half of He at $\mathrm{Y}-10$ is from the mantle leaves $2-5 \mu \mathrm{m} / \mathrm{kg}$ of radiogenic ${ }^{4} \mathrm{He}$ to be used in calculating an age of the associated water. The lower concentration of crustal He in Y-10 relative to CUT, however, does not necessarily indicate a younger age of water, but may be caused by higher porosity and lower $U$ and $T h$ contents of its aquifer rocks.

Preliminary (uncorrected) ${ }^{14} \mathrm{C}$ ages (table F-2) calculated for the total dissolved $\mathrm{C}$ for the CUT well and La Duke Hot Spring give an age of about 25,000 years. These waters have essentially no tritium, but the calculated age may be lower than the true age if a portion of dissolved $C$ is derived from the relatively young organic matter (soil gas). However, the 25,000 years probably is a high ${ }^{14} \mathrm{C}$ age because a large portion of $\mathrm{C}$ in thermal waters likely is derived from Paleozoic limestones. The water at $\mathrm{Y}-10$ has essentially no tritium also, and yields a higher $(31,000$ years $){ }^{14} \mathrm{C}$ age, but the proportion of $\mathrm{C}$ from Paleozoic limestones (based on $\delta^{13} \mathrm{C}$ values of dissolved $\mathrm{C}$ ) and that presumably accompanying the ${ }^{3} \mathrm{He}$ from the mantle source is probably higher than that at CUT. The ${ }^{14} \mathrm{C}$ and model $\mathrm{He}$ ages indicate that the bulk of thermal waters from Mammoth Hot Springs and Corwin Springs KGRA may be older (possibly much older) than 10,000 years.

\section{Solute Isotopes}

Water samples were collected for analysis of the stable and radiogenic isotope compositions of $\mathrm{S}, \mathrm{C}, \mathrm{B}, \mathrm{Cl}, \mathrm{Li}, \mathrm{Sr}, \mathrm{Pb}, \mathrm{Nd}, \mathrm{Ra}$, and $\mathrm{U}$. The $\mathrm{B}$ isotope analyses for water samples reported here were mainly performed by Lynton Land (U. of Texas, Austin); isotopic analyses of B also were performed at MIT (Palmer and Sturchio, 1990). Isotope ratios of $\mathrm{Li}$ and $\mathrm{Sr}$ were measured at Argonne National Laboratory, Argonne, Illinois, and at USGS, Menlo Park, California. Measured $\mathrm{B}, \mathrm{Li}$, and $\mathrm{Sr}$ isotopic compositions for replicate samples determined at the different facilities agree within the limits of analytical precision.

Results of several solute isotopic analyses from selected water samples in the study area are shown in table F-2. Results of selected isotopic analyses for several travertine and other rock samples are shown in table F-5. An extensive data set on the $\mathrm{Sr}, \mathrm{Pb}$, and $\mathrm{Nd}$ isotopic compositions of volcanic, granitic, sedimentary and metamorphic rocks of all ages from the region is available (Leeman and others, 1977; Doe and others, 1982; Wooden and Mueller, 1988; Hildreth and others, 1991) and is used to help determine the origin of solutes in this investigation.

Because $\mathrm{Sr}$ geochemistry is very similar to that of $\mathrm{Ca}$, which is the dominant cation in the thermal waters from both Mammoth Hot Springs and Corwin Springs KGRA, ${ }^{87} \mathrm{Sr}{ }^{\beta 6} \mathrm{Sr}$ ratios are diagnostic of the source of $\mathrm{Ca}$ in water and travertine deposits. Results (table F-2) show that the values for water samples from the Corwin Springs KGRA $\left({ }^{87} \mathrm{Sr}{ }^{86} \mathrm{Sr}=0.716-0.719\right)$ are more radiogenic than those for samples from the Norris-Mammoth area of the Park. The separation of the two groups is enhanced by plotting the $\mathrm{Sr}$ isotope ratios against the weight ratios of $\mathrm{Sr} / \mathrm{Cl}$ (fig. F-7). It should be noted that the concentrations of $\mathrm{Sr}$ (and $\mathrm{Ca}$ ) in thermal waters from Norris Geyser Basin are low, but those in waters from Mammoth, especially from the Y-10 well are comparable to those from the Corwin Springs KGRA. 


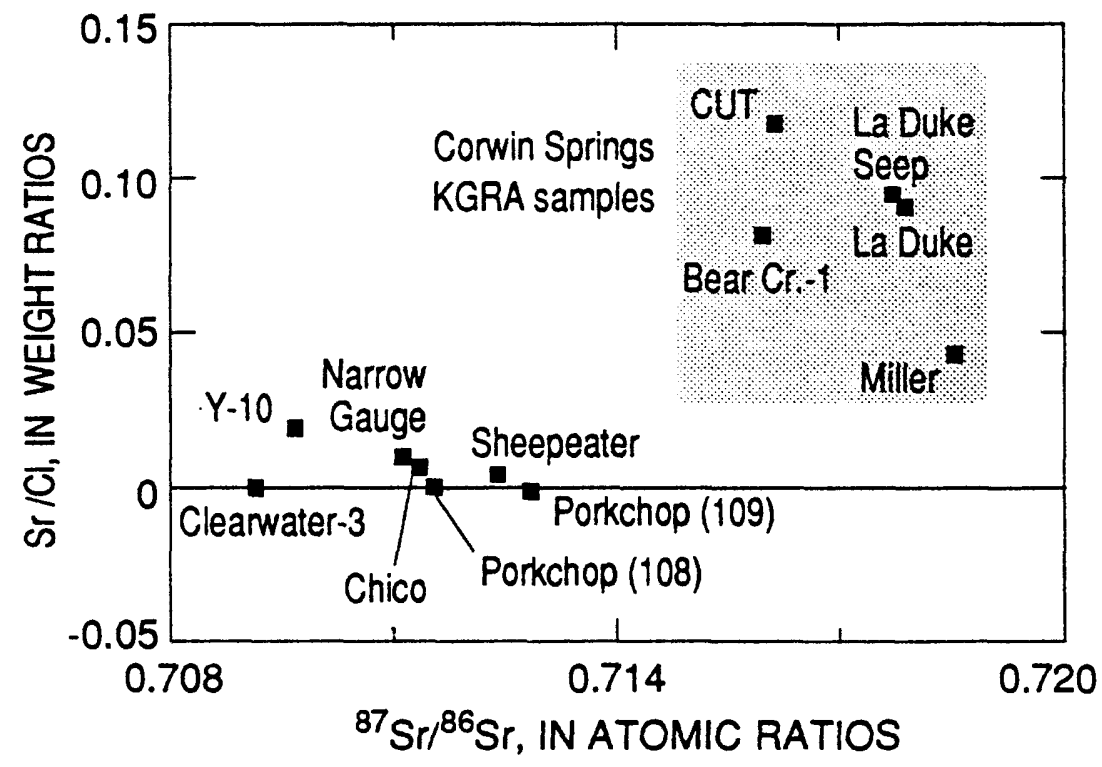

Figure F-7. Relation between ${ }^{87} \mathrm{Sr} /{ }^{86} \mathrm{Sr}$ (strontium-87/strontium-86) ratios and the $\mathrm{Sr} / \mathrm{Cl}$ (strontium/chloride) weight ratios in selected thermal waters from the study area. Numbers used to distinguish certain features correspond to sample numbers listed in table F-1. Note the more radiogenic $\mathrm{Sr}$ isotopes in samples from Corwin Springs Known Geothermal Resources Area compared to those from Mammoth (Narrow Gauge and Y-10). 
The ${ }^{87} \mathrm{Sr} /{ }^{\beta 6} \mathrm{Sr}$ ratios of the travertines are, as expected, identical to those of the associated thermal waters (table F-5). All the travertines ( $>20$ samples) analyzed from the Mammoth area, that range in age from present to more than 400,000 years (Pierce and others, this volume), give ${ }^{87} \mathrm{Sr} /{ }^{86} \mathrm{Sr}$ ratios of 0.710 to 0.712 . There are no significant travertine precipitates in the La Duke Spring area, but extensive travertine deposits (age 0-10,000 years) from the Bear Creek Springs area yield ${ }^{87} \mathrm{Sr}{ }^{\beta 6} \mathrm{Sr}$ ratios of 0.716 . Travertine deposits from the Rattlesnake mound site, across the Yellowstone River from Bear Creek Springs (see fig. C-8 in Pierce and others, this volume) have an age of about 57,000 years and a strontium isotope ratio of 0.713 that is intermediate between that of Bear Creek Springs and Mammoth Hot Springs. Finally, travertines located on terraces north of Gardiner (see fig. C-8 in Pierce and others, this volume) have ages that cluster near 20,000 and 55,000 years and yield $\mathrm{Sr}$ isotope ratios of 0.712 . The values for Gardiner travertine are identical to the values of travertines from the Mammoth area, but distinctly different from the values for water from La Duke Hot Spring or Bear Creek Springs. These Sr isotope values indicate that the travertines near Gardiner were precipitated from Mammoth-type water, and therefore that Mammothtype water is capable of transferring to and emanating from locations outside Mammoth Hot Springs.

The ${ }^{87} \mathrm{Sr} /{ }^{86} \mathrm{Sr}$ ratios of thermal waters and travertines from the Park are within the range of values for Yellowstone rhyolites and Paleozoic limestones and other sedimentary rocks (table F-5) measured for this study and those reported by others (Leeman and others, 1977; Doe and others, 1982; Hildreth and others, 1991). The $\delta^{34} \mathrm{~S}$ values of dissolved sulfate from the Mammoth area (table F-2) are 21.0 to $21.5 \%$ and are within the range expected from dissolution of Middle Paleozoic marine anhydrite as the source of S (Claypool and others, 1980). The $\delta^{13} \mathrm{C}$ values of dissolved carbonate (table F-2) together with the chemical composition of thermal water can be combined with $\delta^{34} \mathrm{~S}$ values to indicate that Middle Paleozoic marine anhydrites and carbonates are the source of most of the $\mathrm{Ca}$ and thus the $\mathrm{Sr}$ in the Mammoth area.

The $\delta^{34} \mathrm{~S}$ values of dissolved sulfate from the Corwin Springs KGRA are similar to those from the Mammoth area and also indicate dissolution of Middle Paleozoic marine anhydrite. The low ${ }^{228} \mathrm{Ra} /{ }^{226} \mathrm{Ra}$ activity ratios of thermal waters from the Corwin Springs KGRA $(0.26-0.69)$, which are determined by the $\mathrm{Th} / \mathrm{U}$ ratios of the aquifer rocks, are those expected from reactions with limestone aquifers. Because limestones of the Madison Group may be an important aquifer in the area (Pierce and others, this volume), it may be the source of the main reactive solutes including the more radiogenic $\mathrm{Sr}\left({ }^{87} \mathrm{Sr}{ }^{86} \mathrm{Sr}\right.$ ratios of 0.716 to 0.719$)$ in the thermal waters. This conclusion is based on results obtained for the three Madison Group samples (table F-5) that yield ${ }^{87} \mathrm{Sr}{ }^{\beta 6} \mathrm{Sr}$ ratios of up to 0.717 for the leached (carbonate) portions and up to 0.722 for the whole-rocks. It is also possible that the water from the Corwin Springs KGRA leaches a portion of its $\mathrm{Sr}$ from the Precambrian rocks that crop out in the Beartooth uplift. Because the ${ }^{87} \mathrm{Sr}{ }^{86} \mathrm{Sr}$ ratios of the Precambrian rocks can be very high (up to 0.783 ; Wooden and Mueller, 1988), only a small amount of $\mathrm{Sr}$ needs to be leached from these rocks and mixed with $\mathrm{Sr}$ from Paleozoic limestone. Regardless of possible reactions with Precambrian rocks, however, the Sr isotopes indicate that the waters from Mammoth Hot Springs and Corwin Springs KGRA have reacted with rocks having some different isotopic characteristics.

The concentrations and isotopic ratios of $\mathrm{Pb}$ and $\mathrm{Nd}$ in selected thermal water and rock samples (tables F-2 and F-5) were determined primarily to investigate the influence of Precambrian rocks on the geochemistry of thermal waters. The $\mathrm{Pb}$ isotopic ratios, however, did not prove diagnostic as the ratios in all the water samples analyzed for this study define very narrow ranges 
(a range of 2.02 to 2.06 is obtained for the ${ }^{208} \mathrm{~Pb} /{ }^{06} \mathrm{~Pb}$, for example) and show no differences between the samples from the Corwin Springs KGRA and those from the Park (table F-5). Results of the isotopic ratios of $\mathrm{Nd}$ in thermal waters and travertines show more variations than those of $\mathrm{Pb}$ and are, in general, more useful for this study because the Precambrian rocks in the area are depleted in ${ }^{143} \mathrm{Nd}\left(\epsilon_{\mathrm{Nd}}<-19\right)$ relative to the volcanic rocks and Paleozoic limestones ( $\epsilon_{\mathrm{Nd}}$ equal 0 to 10) (Hildreth and others, 1991). Results show (table F-2) that Nd concentrations in thermal waters are very low and that $\epsilon_{\mathrm{Nd}}$ values for waters from La Duke (-14.7) and Bear Creek-1 (-14.1) are shifted in the direction of Precambrian rocks compared with most waters from the Norris-Mammoth area $(-2.3$ to -10.0$)$ (table F-2). The water sample from Narrow Gauge $\left(\epsilon_{\mathrm{Nd}}=-17.4\right)$ is an exception and may indicate secondary sources for its $\mathrm{Nd}$, especially since travertine samples from the vicinity of Narrow Gauge give $\epsilon_{\mathrm{Nd}}$ values of -2.2 and -4.7. Results also show that the travertine deposits to the north of Gardiner have an $\epsilon_{\mathrm{Nd}}$ value of about -6 , a value that is identical to the travertines and the majority of thermal waters from Mammoth Hot Springs, and distinctly different from the Bear Creek and La Duke waters. This observation further supports the notion based on Sr isotopes that the Gardiner travertines precipitated from Mammoth-type water.

Dissolved $\mathrm{Cl}, \mathrm{B}$, and even $\mathrm{Li}$ generally behave as the most conservative elements in subsurface waters and as such their concentrations, and especially their isotopic ratios, are the most useful geochemical tools in the investigation of mixing in natural waters. As discussed previously, the concentrations of these elements are relatively high in thermal waters from Yellowstone National Park and decrease with the addition of meteoric water to the mixed fluid (fig. F-3). It is necessary to mention here that published B (Bassett, 1990) and especially Li (Chan and Edmond, 1988) isotopic data for waters and rocks are sparse and may contain erroneous values. Because of greatly improved analytical methodology in the last five years, however, our understanding of the geochemical behavior of $\mathrm{B}$ and $\mathrm{Li}$ isotopes including their fractionation factors have greatly improved (Spivack and Edmond, 1987; Chan and Edmond, 1988; Bassett, 1990; Palmer and Sturchio, 1990). Note that the B and $\mathrm{Li}$ isotopic values in table F-2 were replicated to about \pm 1 $\%$ by analysts from at least two separate laboratories.

The $\delta^{11} \mathrm{~B}$ values for thermal waters in the study area range from -9.4 to 5.4 (table $\mathrm{F}-2$ ). The values for samples from Mammoth Hot Springs are the most depleted in ${ }^{11} \mathrm{~B}$, with $\delta^{11} \mathrm{~B}$ values becoming heavier in samples from Norris Geyser Basin and even heavier in samples from the La Duke Spring area of the Corwin Springs KGRA (fig. F-8). The possible controls on B isotopic ratios of this study are discussed in Kharaka and others (1990), and Palmer and Sturchio (1990). It suffices to mention here that plots of $\delta^{11} \mathrm{~B}$ values versus $\mathrm{B}$ concentrations (fig. $\mathrm{F}-8$ ) and $\mathrm{Cl}$ concentrations (not shown) show that waters from Bear Creek-1 could be derived by mixing of a Mammoth-type component with water similar to that from Chico Hot Spring. Note that the samples from La Duke Spring area plot in a position indicating little or no Mammoth-type component in those waters.

The $\delta^{6} \mathrm{Li}$ values for the eight water samples analyzed for this study (table F-2) range from -1.0 to $14 \%$ relative to the NBS L-SVEC standard $\mathrm{LiCO}_{3}$ that yielded replicate ${ }^{6} \mathrm{Li} / \mathrm{Li}$ ratios of 0.08210 . The waters from the Corwin Springs KGRA are depleted in ${ }^{6} \mathrm{Li}$ relative to the sample from Mammoth as well as the other samples from the Norris-Mammoth corridor. The isotope values indicate that different sources of $\mathrm{Li}$ and possibly some mixing with water from the Mammoth system control the $\mathrm{Li}$ isotopes in waters from the Corwin Springs KGRA. 


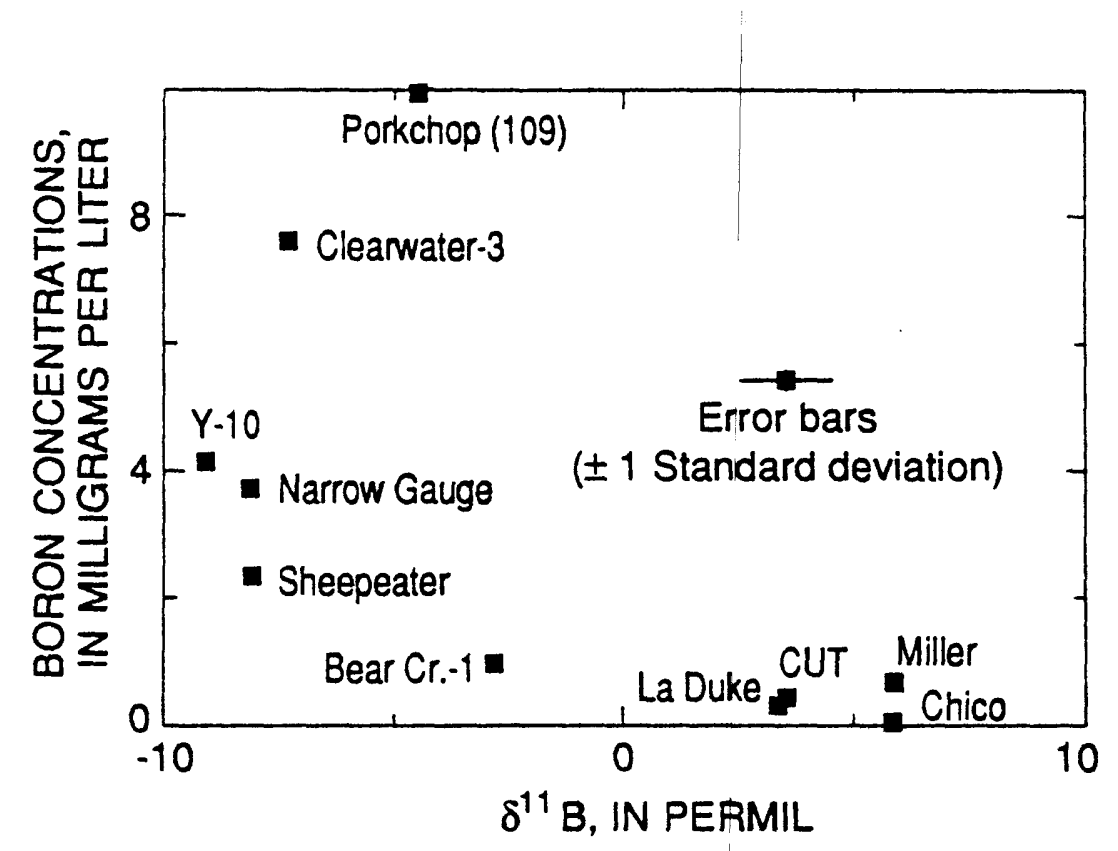

Figure F-8. The $\delta^{11} \mathrm{~B}$ (boron-11) values and concentrations of B (boron) in selected thermal waters from the study area. Number used with the value for Porkchop corresponds with sample number in table F-1. Note that the sample from Bear Creek-1 plots between those from Mammoth (Narrow Gauge and Y-10) and those from La Duke area (La Duke, CUT, and Miller) and Chico Hot Spring indicating possible mixing. 


\section{Mammoth-Corwin Springs Known Geothermal Resources Area Connections}

The isotopes of water and the concentrations and isotopic ratios of solutes and gases have been used in this study to help understand the origins of thermal water and solutes, and thus to infer any hydraulic connections between the Corwin Springs KGRA and Yellowstone National Park. Primarily on the basis of geologic and hydrologic considerations, a connection could conceivably exist with fluids from the Mammoth hydrothermal system as discussed by Pierce and others (this volume). These considerations indicate that a connection with other main thermal features of the Park (for example Norris Geyser Basin) along the East Gallatin-Reese Creek faults is much less likely. This conclusion is probably supported by the typically crustal He isotope value $(\mathrm{R} / \mathrm{RA}=$ 0.05) obtained from Sawmill Creek Spring located on a segment of the Reese Creek fault system (fig. F-1), assuming that the $\mathrm{He}$ in this cold site (temperature $=8^{\circ} \mathrm{C}$ ) reflects the fluid conditions at depth.

In this section, the components of a Mammoth-type thermal water in the waters of La Duke Spring and Bear Creek-1, are calculated (table F-7). The calculations are based on a mass balance approach using the concentrations and isotopic ratios of $\mathrm{Cl}, \mathrm{Li}, \mathrm{B}$, and $\mathrm{He}$, the most conservative chemical constituents in these waters. The equations used for calculating proportional mixing in water from two end members are:

$$
\begin{gathered}
m_{3}=m_{1} x_{1}+m_{2}\left(1-x_{1}\right) \\
\delta_{3} m_{3}=\delta_{1} m_{1} x_{1}+\delta_{2} m_{2}\left(1-x_{1}\right)
\end{gathered}
$$

where subscripts 1,2 and 3 refer to the two end members and the mixture, respectively, $m$ is the concentration of a dissolved chemical component (for example, $\mathrm{Cl}$ ), $\mathrm{x}$ is the proportion of the subscripted end member in the mixture, and $\delta$ is the solute isotope ratio (for example, ${ }^{11} \mathrm{~B} /{ }^{10} \mathrm{~B}$ ) or the value of the isotope deviation function (for example, $\delta^{11} \mathrm{~B}$ in permil). The equation based on $\delta \mathrm{D}$ and $\delta^{18} \mathrm{O}$ values of water is:

$$
\delta_{3}=\delta_{1} x_{1}+\delta_{2}\left(1-x_{1}\right) .
$$

These model calculations require two end members: the Mammoth-type water is assumed to have the chemical and isotopic compositions of water in the $\mathrm{Y}-10$ well and is used as the first end member. The water from the Y-10 well is probably the least modified of the Mammoth sites and the most representative of the upflow fluids for the Mammoth system, and therefore its selection as an end member is appropriate. Selecting the second end member that meets all the mathematical and geochemical requirements of equations $5-7$, however, is more difficult. Ideally, the second end member would have many of the chemical and isotopic characteristics of waters from La Duke Spring and Bear Creek-1. This end member, of course, must not have any component of water from the Mammoth system; this requirement would rule out from consideration any sites located in the Norris-Mammoth corridor. Geochemical data, discussed in earlier sections, show that any mixing would have to take place at temperatures higher than about $70^{\circ}$ to $80^{\circ} \mathrm{C}$, the subsurface temperatures calculated from chemical geothermometers for the waters of Bear Creek-1 and La Duke Spring, respectively (table F-6); these temperature requirements would exclude any shallow ground water wells or cold springs from consideration for the end member. 
The approach chosen for this study was to examine the chemical and isotopic compositions of thermal and cold waters from about 10 sites located mainly in the Gallatin Range and Beartooth uplift to the north of the Park (table F-1 and F-2), but extending to Bozeman Hot Spring located far north of the Park in Gallatin County, Montana. Bozeman Hot Spring has an estimated subsurface temperature and several chemical components comparable to those of La Duke Hot Spring (Mariner and others, 1976). Of all the sites examined, the water from Chico Hot Spring, located about 30 $\mathrm{km}$ north of Corwin Springs in the Beartooth uplift (fig. F-1) is probably the most suitable as the second end member. The water from Chico Hot Spring has a calculated subsurface temperature of about $55^{\circ} \mathrm{C}$, and is of the $\mathrm{Na}-\mathrm{Ca}-\mathrm{HCO}_{3}-\mathrm{SO}_{4}$ type as are the waters from La Duke Hot Spring and Bear Creek-1. The mixing proportions calculated from equations 5-7, however, will not be based on geochemical data from Chico Hot Spring alone but from all the miscellaneous samples examined (tables F-1 and F-2). The error margins discussed below will carry the analytical uncertainties as well as the uncertainties involved in selecting a range of values for the second end member.

The mixing proportions reported in table $\mathrm{F}-7$ using the concentrations of $\mathrm{Cl}, \mathrm{B}$ and $\mathrm{Li}$ are based on the assumption of water from Chico Hot Spring as the second end member. The mixing proportions obtained (about $10-20$ percent for La Duke Hot Spring and $20-24$ percent for Bear Creek-1), however, will not change significantly if it is assumed that the concentration of these solutes in the second end member are equal to zero. The concentrations of $\mathrm{Cl}, \mathrm{B}$ and $\mathrm{Li}$ in water from Chico Hot Spring are low and are the lowest of all the thermal sites examined (table F-1). Thus, the mixing proportions in table F-7 are maximum values, and lower values including zero, may be calculated with concentrations of $\mathrm{Cl}, \mathrm{B}$ and $\mathrm{Li}$ in the second end member that are higher compared to values from Chico Hot Spring. Because the mixing proportions calculated from each of the three solutes are upper limits, the possible component of Mammoth-type water in La Duke Hot Spring can have a range of $0-10$ percent. By similar reasoning, the possible component of Mammoth-type water in Bear Creek-1 can have a range of $0-20$ percent. The fact that the mixing proportions calculated for Bear Creek-1 with $\mathrm{Cl}, \mathrm{B}$ or $\mathrm{Li}$ concentrations are approximately the same, may support the mixing hypothesis for this site.

The mixing proportions calculated using the isotopes of water are generally reliable except for the fact that the values reported here (table F-7) are subject to large uncertainties because the differences in $\delta D$ and $\delta^{18} \mathrm{O}$ values for waters at Mammoth and the Corwin Springs KGRA are relatively small and analytical errors are large relative to these differences. Note that the values in table F-7 are calculated using $\delta \mathrm{D}$ and $\delta^{18} \mathrm{O}$ values for end members obtained by connecting lines between the values for water from the Y-10 well and those from La Duke Hot Spring and Bear Creek-1 and extrapolating the lines to the meteoric water line (fig. F-5). The most plausible values based on water isotopes are 0 and 10 percent for the waters at La Duke Spring and at Bear Creek-1, respectively. The error margin in these calculations is large and is estimated at about \pm 15 percent.

The solutes $\mathrm{B}$ and $\mathrm{Li}$ are particularly suitable for calculating proportional mixing because of the already discussed observation that $\mathrm{B}$ and $\mathrm{Li}$ concentrations in thermal waters from Yellowstone National Park are high and that $\mathrm{B}$ and $\mathrm{Li}$ isotopic ratios are mainly determined by the sources of $\mathrm{B}$ and $\mathrm{Li}$. Modifications of B concentrations and isotopic ratios by subsequent exchange and other chemical reactions are likely to be of secondary importance (Spivack and Edmond, 1987; Kharaka and others, 1990; Palmer and Sturchio, 1990). Even though dissolved $\mathrm{Li}$ is considered one of the least reactive cations, modifications of Li concentrations and isotopes are more likely, especially at 
temperatures higher than about $100^{\circ} \mathrm{C}$ because $\mathrm{Li}$ can substitute for $\mathrm{Mg}$ and to a lesser extent for $\mathrm{Fe}$ in clays and several other minerals (Chan and Edmond, 1988; Kharaka and Mariner, 1989). The $\delta^{11} \mathrm{~B}$ and $\delta^{6} \mathrm{Li}$ for water from Chico Hot Spring were used in equations 5 and 6 as the values for the second end member, first order correlation plots of $\mathrm{B}$ and $\mathrm{Li}$ concentrations and isotopic ratios support this selection. Results of $\delta^{11} \mathrm{~B}$ values (table F-7) show a 2 percent possible Mammoth-type water in La Duke Hot Spring, but possibly a 19 percent component in Bear Creek-1; estimated errors for these calculations are $\pm 5-10$ percent. Results of $\delta^{6} \mathrm{Li}$ values shows about 10 percent possible component of Mammoth-type water in both La Duke Hot Spring and Bear Creek-1; estimated errors are \pm 10 percent.

Dissolved noble gases, if not affected by extreme degassing, are the best geochemical tools to calculate proportional mixing in natural waters because they are totally inert to water-rock interactions and end-member values are well constrained. As discussed previously (see Chemical and Isotope Composition of Gases), the concentrations of $\mathrm{He}(10.3 \pm 0.6 \mu \mathrm{m} / \mathrm{kg})$ and ${ }^{3} \mathrm{He} /{ }^{4} \mathrm{He}$ ratios $(\mathrm{R} / \mathrm{RA}=0.12 \pm 0.01)$ are well constrained for waters from the La Duke area. The concentrations of He in water from the Y-10 well, even though affected by some degassing, can be calculated at $7 \pm 3 \mu \mathrm{m} / \mathrm{kg}$; the ${ }^{3} \mathrm{He} /{ }^{4} \mathrm{He}$ ratios are well constrained at $\mathrm{R} / \mathrm{RA}$ value of 8.4 . There is some uncertainty in selecting a value for the ${ }^{3} \mathrm{He} /{ }^{4} \mathrm{He}$ ratio of "crustal" $\mathrm{He}$ in the area because the R/RA value of 0.24 obtained from Chico Hot Spring is higher than the value of 0.05 predicted for average crust (Mamyrin and Tolstikhin, 1984; and many others) and obtained for the sample from Sawmill Creek Spring. Thus a range of values can be calculated for the component of Mammoth-type water in La Duke Hot Spring. A maximum 2 percent of a Mammoth component can be calculated using 0.05 as the "crustal" end member and $4.0 \mu \mathrm{m} / \mathrm{kg}$ as the lower concentration of He in water from the $\mathrm{Y}-10$ well; a value of 1 percent is calculated using 0.05 as the "crustal" value and $7 \mu \mathrm{m} / \mathrm{kg}$ as the likely $\mathrm{He}$ concentration in water from the $\mathrm{Y}-10$ well. A value of 0 percent is selected in table F-7 because R/RA values for waters from the La Duke Hot Spring area $(0.13$ for CUT and 0.11 for Miller) are lower than that from Chico Hot Spring (0.24) and are interpreted to be "crustal" for the area. The higher ${ }^{3} \mathrm{He}$ concentrations in waters from the La Duke area and Chico Hot Spring compared with those expected from average crust are not unusual and could be related to the presence of basalts in the area or higher $\mathrm{Li}$ concentrations than average crust $(60 \mathrm{ppm})$ in local aquifers.

The chemical composition of dissolved gas in Bear Creek-1 gives an extremely low concentration of $\mathrm{He}$ and shows extensive degassing and interaction with atmospheric gases (table F-4). Calculation of the concentration of $\mathrm{He}$ in the undegassed water is complicated further because tritium concentrations indicate that 25 to 50 percent of the water from Bear Creek-1 is post 1960 ground water. The concentrations of He calculated assuming bulk stripping range from about 0.3 to $1.0 \mu \mathrm{m} / \mathrm{kg}$; calculations based on Rayleigh-type distillation give unrealistically high values. The range of Mammoth-type water in Bear Creek-1 based on these concentrations and the isotopes of He range up to about 1 percent. Alternatively, due to the uncertainty in He concentration in Bear Creek-1, a more representative value of 3 percent is obtained from the isotope values alone, as shown below:

$$
\frac{0.29-0.05}{8.4-0.005} \times 100=3 \text { percent. }
$$


A second dissolved gas sample was obtained from Bear Creek-1, but the results were approximately the same and equally poor as the values in table F-4. At this site, drilling might be necessary to obtain an undegassed sample.

The selected values of percentages of Mammoth-type thermal water in La Duke Hot Spring and Bear Creek-1 (table F-7) are based on solute isotopic ratios. The value of zero selected for La Duke Hot Spring is based on He, B, and water isotopes and is much more tightly constrained than the percentage calculated for Bear Creek-1; the error margin is probably less than \pm 5 percent. The conclusion of a zero Mammoth component in water from La Duke Hot Spring and other thermal sites in the La Duke area is supported by other geochemical data. The most useful data in this regard are the $\mathrm{He}-\mathrm{Ar}$ isotopic ratios depicted in figure $\mathrm{F}+6$, which show that the samples from the CUT and Miller wells plot significantly outside the field for all the waters from Yellowstone National Park. The absence of significant travertine deposits from the La Duke area, the relatively low dissolved gas pressure of $\mathrm{CO}_{2}(0.2$ bars), and the differences in isotopic ratios of $\mathrm{Sr}, \mathrm{Nd}, \mathrm{Ra}$ and other solutes relative to Mammoth water, are additional supporting geochemical data for the above conclusion.

The isotopes of $\mathrm{B}, \mathrm{Li}$, as well as the $\delta \mathrm{D}$ and $\delta^{18} \mathrm{O}$ values of water (table $\mathrm{F}-7$ ) indicate a $0-20$ percent possible component of Mammoth-type water in Bear Creek-1. The most plausible value within the above range is a 10 percent component of Mammoth-type water in Bear Creek-1. The mixing proportions calculated for this area, however, carry larger estimated errors of \pm 10 percent. Note that the He-Ar isotopic ratios (fig. F-6) indicate that the sample from Bear Creek-1 plots close to the field for the waters from the Mammoth and other areas of Yellowstone National Park possibly indicating a Mammoth component in waters from Bear Creek-1. Additional supporting geochemical evidence for a Mammoth component in water from Bear Creek-1 and -2 (the bulk of thermal water in the area) comes from the extensive travertine deposits in the area, the intermediate gas pressure of $\mathrm{CO}_{2}$ (about 1.0 bars) and $\mathrm{Sr}$, and some other solute isotopic ratios.

\section{$\underline{\text { Summary and Conclusions }}$}

An extensive geochemical data set consisting of detailed chemical and isotopic compositions of water, solutes, gases, and rocks has been obtained in order to help understand the origins and evolutions of waters, and to investigate possible hydraulic connections between thermal sites in the Corwin Springs KGRA and adjacent areas of Yellowstone National Park. The salinity and concentrations of major cations and anions, with the exception of $\mathrm{Cl}$, are comparable in the thermal waters from Corwin Springs KGRA and Mammoth Hot Springs. However, the concentrations and isotopic ratios of the most conservative solutes $\mathrm{He}, \mathrm{Cl}, \mathrm{Br}, \mathrm{B}$, and $\mathrm{Li}$ are different and proved particularly useful in quantifying possible mixing proportions of Mammoth-type water in waters of the KGRA. Quantitative results from even the most diagnostic geochemical parameters, however, are not conclusive and are subject to individual uncertainty of up to \pm 10 percent.

The hydrothermal system at Mammoth Hot Springs has been active for at least the last 400,000 years. The thermal water for the Mammoth system is meteoric and likely originates from precipitation in the Gallatin Range to the west. In one model, based on He isotopes, gas and heat discharges, and $\mathrm{C} \beta \mathrm{He}$ ratios, the bulk of heat and some volatile components for the Mammoth 
thermal waters are provided by a cooling magmatic source located beneath the Mammoth area. The water acquires its conservative solutes mainly by reactions with local Precambrian rocks at high temperatures, and acquires $\mathrm{Ca}, \mathrm{Mg}, \mathrm{SO}_{4}$, and some $\mathrm{HCO}_{3}$ by reactions with local Paleozoic limestones and anhydrite at about $100^{\circ} \mathrm{C}$. Alternatively, Mammoth water could result from the mixing of $60-70$ percent dilute meteoric water and 40 - 30 percent thermal water from the Norris Geyser Basin system. The mixed water in this model also has to react with local Paleozoic sedimentary rocks at about $100^{\circ} \mathrm{C}$ to acquire most of its reactive solutes.

The geochemical data, especially the $\mathrm{Sr}$ and $\mathrm{Nd}$ isotopes, could indicate a significant component of recharge in the Beartooth uplift for the thermal waters in the Corwin Springs KGRA. The water acquires its chemical species by reactions with the granitoids and metasediments of the Beartooth uplift during descent and by reactions with Paleozoic limestones (at $70^{\circ}$ to $80^{\circ} \mathrm{C}$ ) during ascent in the Gardiner fault zone. The geochemical data in general and the concentrations and isotopic ratios of $\mathrm{He}, \mathrm{B}, \mathrm{Li}$, and $\mathrm{Cl}$ and water isotopes in particular indicate that (1) the thermal water from the La Duke Hot Spring area has evolved by reactions with rocks having some chemical and isotope characteristics different from those encountered by Mammoth water and, subject to \pm 5 percent uncertainty, no Mammoth-type water is detected in the La Duke area; and (2) about 10 \pm 10 percent (range of $0-20$ percent) of thermal water from the Bear Creek Springs area may be obtained from the Mammoth system.

\section{Acknowledgments}

We would like to thank Gil Ambats, William C. Evans, James J. Thordsen and Lloyd D. White, USGS, Menlo Park for making important contributions to all aspects of this investigation, including sample collection and laboratory analysis. Their names are excluded from authorship only to keep the list reasonable. We gratefully acknowledge the logistical support that we obtained from Wayne Hamilton and Robert L. Chambers, NPS, Yellowstone National Park.

\section{$\underline{\text { References Cited }}$}

Allen, E.T., and Day, A.L., 1935, Hot springs of the Yellowstone National Park: Carnegie Institution of Washington Publication 466, $525 \mathrm{p}$.

Bargar, K.E., 1978, Geology and thermal history of Mammoth Hot Springs, Yellowstone National Park, Wyoming: U.S. Geological Survey Bulletin 1054-B, 55 p.

Bassett, R.L., 1990, A critical evaluation of the available measurements for the stable isotopes of boron: Applied Geochemistry, v. 5, p. 541-554.

Chan, L.H., and Edmond, J.M., 1988, Variation of lithium isotope composition in the marine environment: a preliminary report: Geochimica Cosmochimica Acta, v. 52, p. 1711-1717.

Claypool, G.E., Holser, W.T., Kaplan, I.R., Sakai, H., and Zak, I., 1980, The age curves of sulfur and oxygen isotopes in marine sulfate and their mutual interpretation: Chemical Geology, v. 28, p. $199-260$.

Clayton, R.N., Friedman, I., Graf, D.L., Mayeda, T.K., Meets, W.F., and Shimp, N.F., 1966, The origin of saline formation waters, I. Isotopic composition: Journal Geophysical Research, v. 71 , p. 3869-3882. 
Craig, H., 1961, Isotopic variations in meteoric waters: Science, v. 133, p. 1702.

Des Marais, D.J., 1989, Thermal $\mathrm{CO}_{2}$ outgassing: Source signatures, sizes and significance: EOS, Transaction of the American Geophysical Union, Abstract, v. 43, p. 1377.

Doe, B.R., Leeman, W.P., Christiansen, R.L., and Hedge, C.E., 1982, Lead and strontium isotopes and related trace elements as genetic tracers in the upper Cenozoic rhyolite-basalt association of the Yellowstone Plateau volcanic field: Journal of Geophysical Research, v. 87, p. 47854806.

Dirks, A.D., and Martner, B.E., 1982, The climate of Yellowstone and Grand Teton National Parks: U.S. Department of Interior, National Parks Service Occasional Paper Six, 26 p.

Ellis, A.J., and Mahon, W.A.J., 1964, Natural hydrothermal systems and experimental hot-water-rock interactions: Geochimica Cosmochimica Acta v. 28, p. 1323-1357.

, 1967, Natural hydrothermal systems and experimental hot-water-rock interactions (Part II): Geochimica Cosmochimica Acta, v. 31, p. 519-538.

-----, 1977, Chemistry and Geothermal Systems, Academic Press, New York, N.Y., 329 p.

Faure, G., 1986, Principles of Isotope Geology, John Wiley and Sons, New York, N.Y., 589 p.

Friedman, I. 1970, Some investigations of the deposition of travertine from Hot Springs - I. The isotopic chemistry of travertine-depositing springs: Geochimica Cosmochimica Acta, v. 34, p. $1,303-1,315$.

Fournier, R.O., 1981, Application of water chemistry to geothermal exploration and reservoir engineering, in Rybach, L., and Muffler, L.J.P., eds., Geothermal Systems: Principles and Case Histories. New York, Wiley, p. 109-143.

-----, 1989, Geochemistry and dynamics of the Yellowstone National Park hydrothermal system: Annual Review Earth Planetary Science, v. 17, p. 13-53.

Giggenbach, W.F., Gonfianti, R., Jangi, B.L., and Truesdell, A.H., 1983, Isotopic and chemical composition of Parbati Valley geothermal discharges, N.W. Himalaya, India: Geothermics, v. 12 , p. 199-222.

Gooch, F.A., and Whitfield, J.E., 1888, Analyses of waters of the Yellowstone National Park, with an account of the methods and analysis employed: U.S. Geological Survey Bulletin 47, 84 p.

Hem, J.D., 1985, Study and interpretation of the chemical characteristics of natural water: U.S. Geological Survey Water-Supply Paper 2254, 253 p.

Hildreth, W., Halliday, A.N., and Christiansen, R.L., 1991, Isotopic and chemical evidence concerning the genesis and contamination of basaltic and rhyolitic magma beneath the Yellowstone Plateau volcanic field: Journal of Petrology, v. 32, p. 63-138.

Kennedy, B.M., Lynch, M.A., Reynolds, J.H., and Smith, S.P., 1985, Intensive sampling of noble gases in fluids at Yellowstone: I. Early overview of data; regional patterns: Geochimica Cosmochimica Acta, v. 49, p. 1251-1261.

Kharaka, Y.K., and Carothers, W.W., 1986, Oxygen and hydrogen isotope geochemistry of deep basin brines, in Fitz, P., and Fontes, J. Ch., eds., Handbook of Environmental Isotope Geochemistry, v. II, p. 305-360.

Kharaka, Y.K., and Mariner, R.H., 1989, Chemical geothermometers and their application to formation waters from sedimentary basins, in Thermal History of Sedimentary Basins: Methods and case histories: Naeser, N.D., and McCulloh, T.H., eds., Springer-Verlag, N.Y., p. 99-117.

Kharaka, Y.K., Gunter, W.D., Aggarwal, P.K., Perkins, E.H., and DeBraal, J.D., 1988, SOLMINEQ.88: a computer program for geochemical modeling of water-rock interactions: U.S. Geological Survey Water-Resources Investigation Report 88-4227, 420 p. 
Kharaka, Y.K., Mariner, R.H., Ambats, G., Evans, W.C., White, L.D., Bullen, T.D., and Kennedy, B.M., 1990, Origins of water and solutes in and north of the Norris-Mammoth corridor, Yellowstone National Park: Transactions of the Geothermal Resources Council, v. 14, p. 705714.

Leeman, W.P., Doe, B.R., and Whelan, J., 1977, Radiogenic and stable isotope studies of hot-spring deposits in Yellowstone National Park and their genetic implications: Geochemical Journal, v. 11 , p. 65-74.

Leonard, R.B., Brosten, T.M., and Midtlying, N.A., 1978, Selected data from thermal-spring areas, southwestern Montana: U.S. Geological Survey Open-file Report 78-438, 77 p.273 p.

Mariner, R.H., Presser, T.S., and Evans, W.C., 1976, Chemical characteristics of the major thermal springs of Montana: U.S.Geological Survey Open-File Report 76-480, 31 p.

Mazor, E., and Fournier, R.O., 1973, More on noble gases in Yellowstone National Park hot waters: Geochimica Cosmochimica Acta, v. 37, p. 515-525.

Palmer, M.R., and Sturchio, N.C., 1990, The boron isotope systematics of Yellowstone National Park (Wyoming) hydrothermal system: a reconnaissance: Geochimica Cosmochimica Acta, v. 54, p. 2811-2815.

Plummer, L.N., Busby, J.F., Lee, R.W., and Hanshaw, B.B., 1990, Geochemical modeling of Madison aquifer in parts of Montana, Wyoming, and South Dakota: Water Resources Research, v. 26, p. 1981-2014.

Rowe, J.J., Fournier, R.O., and Morey, G.W., 1973, Chemical analysis of thermal waters in Yellowstone National Park, Wyoming, 1960-1965: U.S. Geological Survey Bulletin 1303, 31 p.

Spivack, A.J., and Edmond, J.M., 1987, Boron isotope exchange between seawater and oceanic crust: Geochimica Cosmochimica Acta, v. 51 p. 1033-1044.

Sturchio, N.C., 1990, Radium isotopes, alkaline earth diagenesis, and age determination of travertine from Mammoth Hot Springs, Wyoming, U.S.A.: Applied Geochemistry, v. 5, p. 631-640.

Thompson, J.M., Presser, T.S., Barnes, R.B., and Bird, D.B., 1975, Chemical analysis of the waters of Yellowstone National Park, Wyoming, from 1965-1973: U.S. Geological Survey Open-File Report 75-25, $59 \mathrm{p}$.

Torgersen, T., and Clarke, W.B., 1985, Helium accumulations in ground water I: An evaluation of sources and the continental flux of crustal ${ }^{4} \mathrm{He}$ in the Great Artesian Basin, Australia: Geochimica Cosmochimica Acta, v. 49, p. 1211-1218.

Truesdell, A.H., and Hulston, J.R., 1980, Isotopic evidence in environments of geothermal systems, in Fitz, P., and Fontes, J. Ch., eds., Handbook of Environmental Isotope Geochemistry, V. I, p. 179-226.

Truesdell, A.H., Nathenson, M., and Rye, R.O., 1977, The effects of subsurface boiling and dilution on the isotopic compositions of Yellowstone thermal waters: Journal of Geophysical Research, v. 82, p. 3694-3704.

Welhan, J.A., 1981, Carbon and hydrogen gases in hydrothermal systems: the search for a mantle source: Ph.D dissertation, University of California, San Diego, California, 194 p.

White, D.E., Hutchinson, R.A., and Keith, T.E.C., 1988. The geology and remarkable thermal activity of Norris Geyser Basin, Yellowstone National Park, Wyoming: U.S. Geological Survey Professional Paper 1456, 84 p.

Wooden, J.L., and Mueller, P.A., 1988, $\mathrm{Pb}, \mathrm{Sr}$, and $\mathrm{Nd}$ isotopic compositions of a suite of Late Archean, igneous rocks, eastern Beartooth Mountains: implications for crust-mantle evolution: Earth and Planetary Science Letters, v. 87, p. 59-73. 


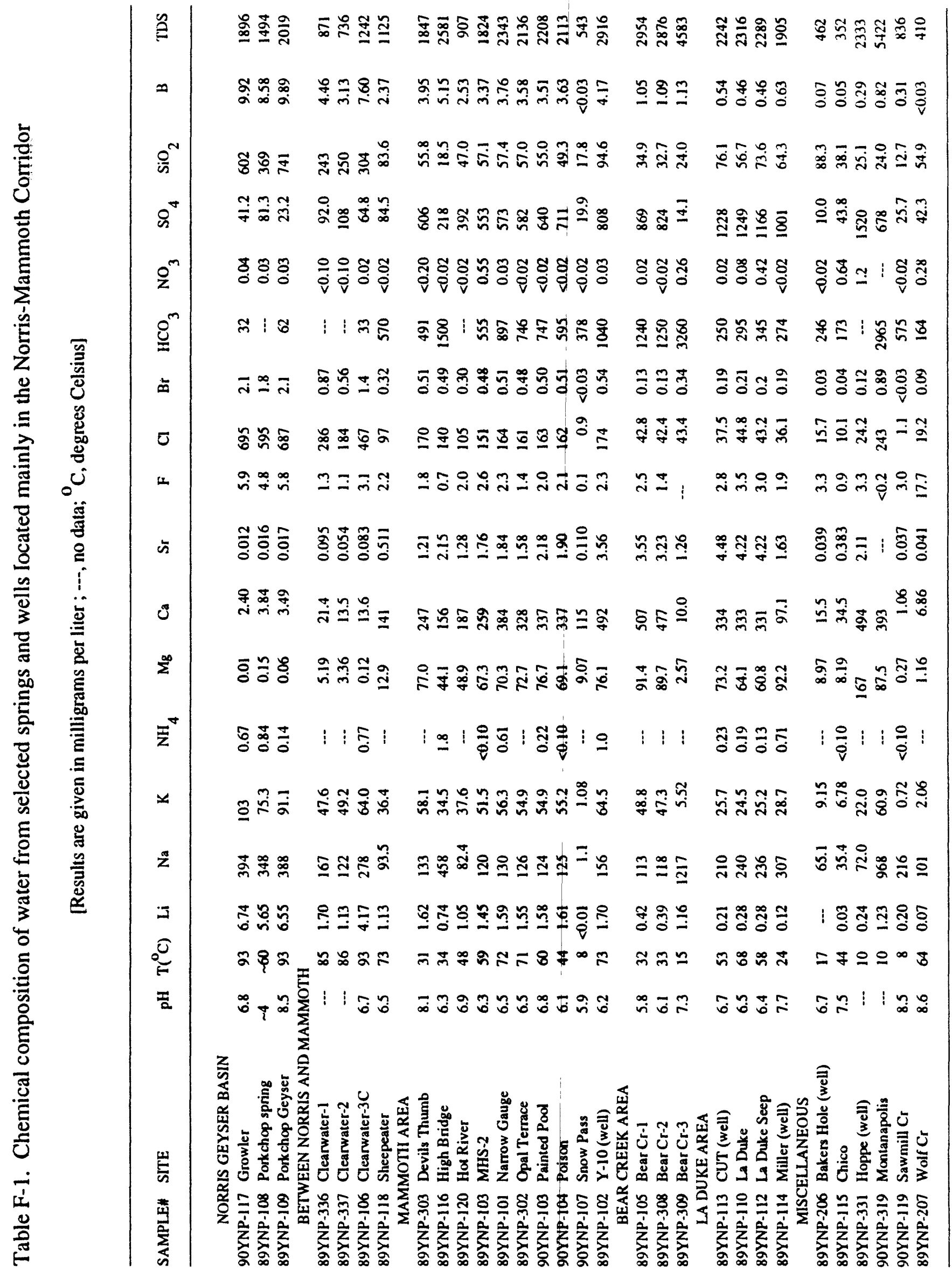




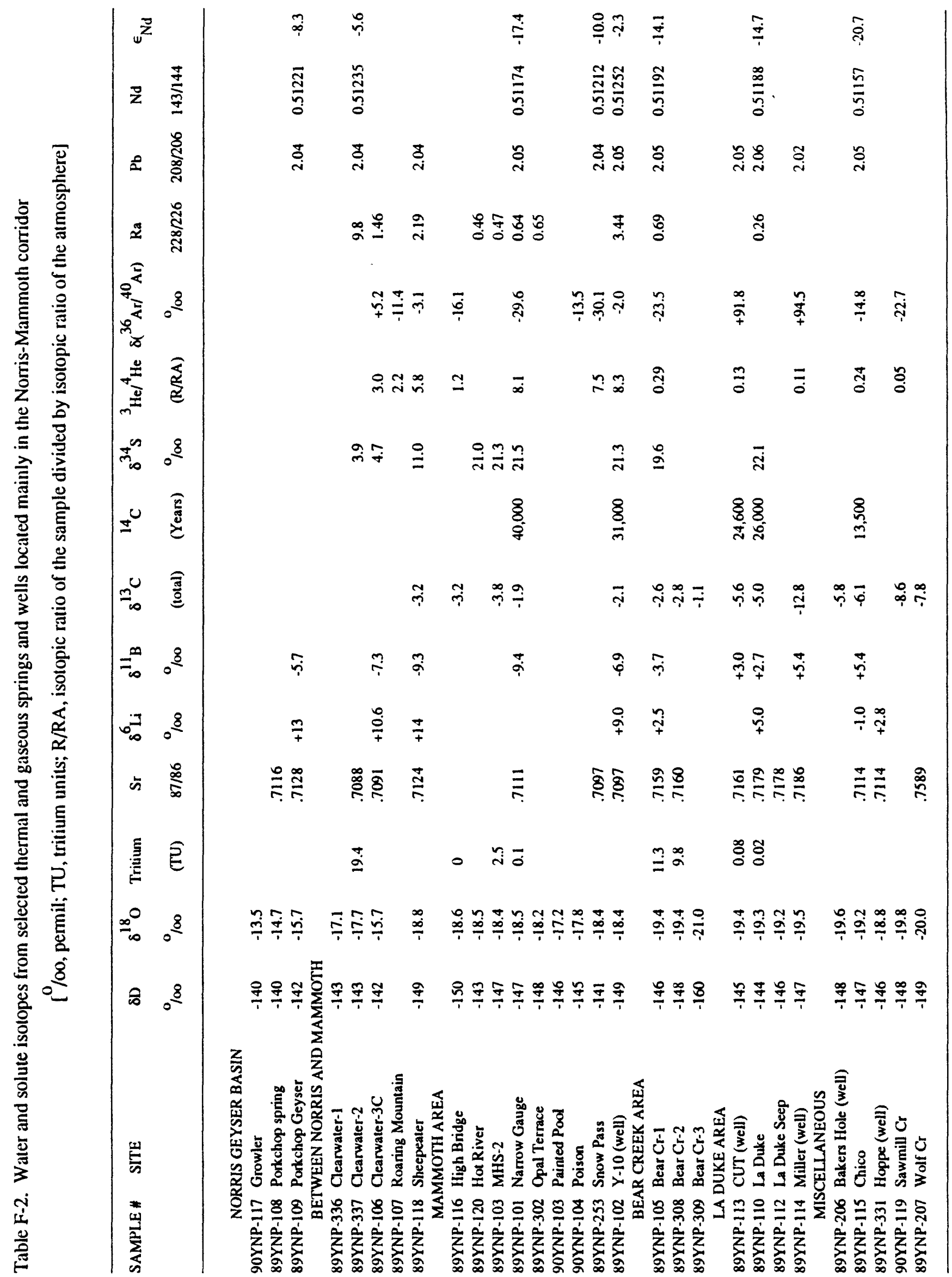




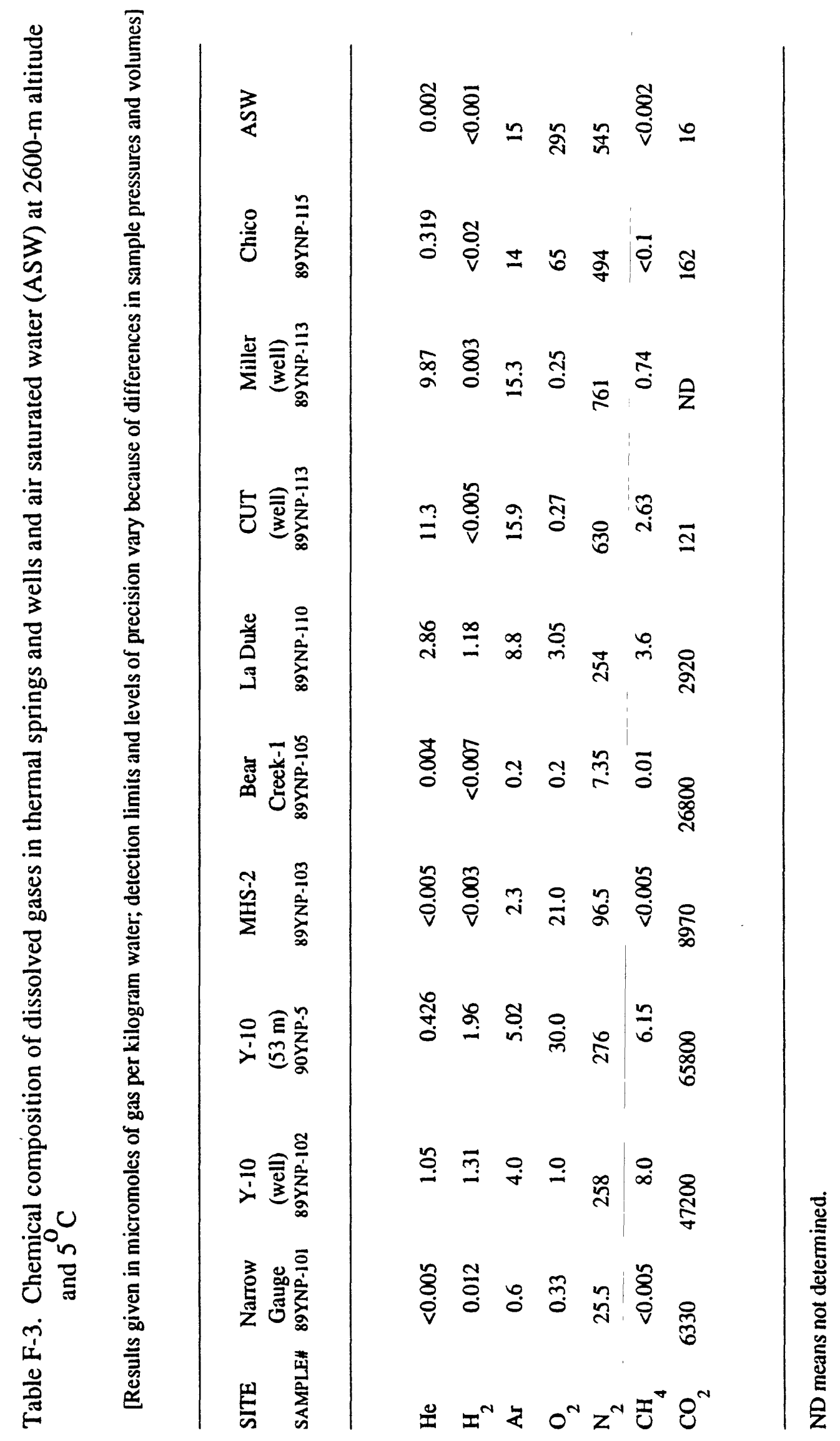


Table F-4. Chemical (mole percent, water-free basis) and isotopic (permil) compositions of gases from gas discharges

[Chemical compositions reported in mole percent; isotopic compositions reported in permil; ..., no data]

\begin{tabular}{ccccccc}
\hline SITE & Roaring & Narrow & Y-10 & Snow & High & Sheepeater Montanapolis Sawmill \\
Mountain & Gauge & (well) & Pass & Bridge & &
\end{tabular}

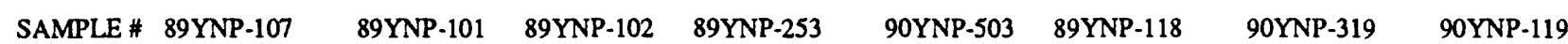

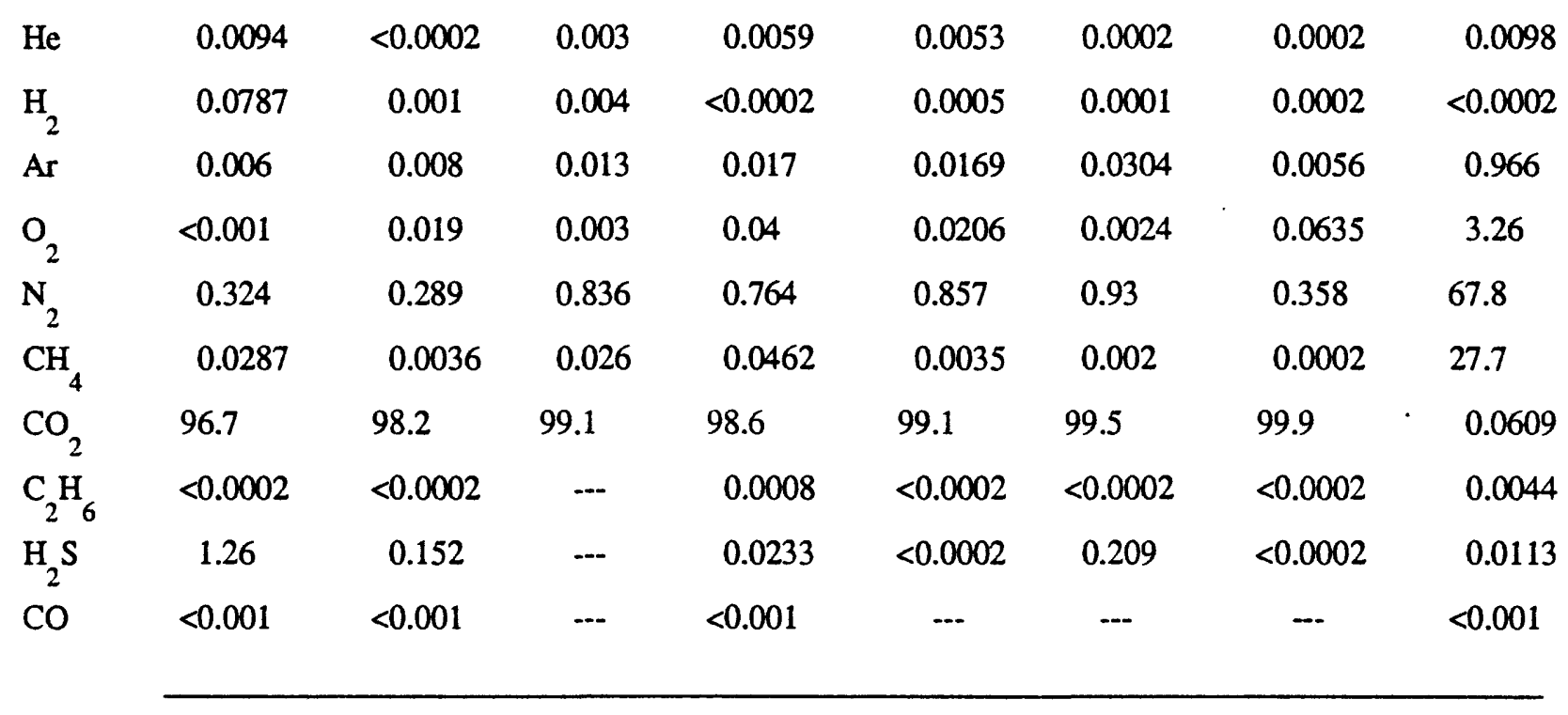

\begin{tabular}{llllllll} 
TOTAL 98.4 & 98.6 & 100.0 & 99.5 & 100.2 & 100.7 & 100.3 & 99.8 \\
$\delta^{13} \mathrm{C}\left(\mathrm{CO}_{2}\right)-3.9$ & -4.1 & -5.2 & -3.4 & -5.1 & -4.4 & -6.2 & $\cdots$ \\
\hline
\end{tabular}


Table F-5. Isotopic values for selected rock, travertine, and mineral samples

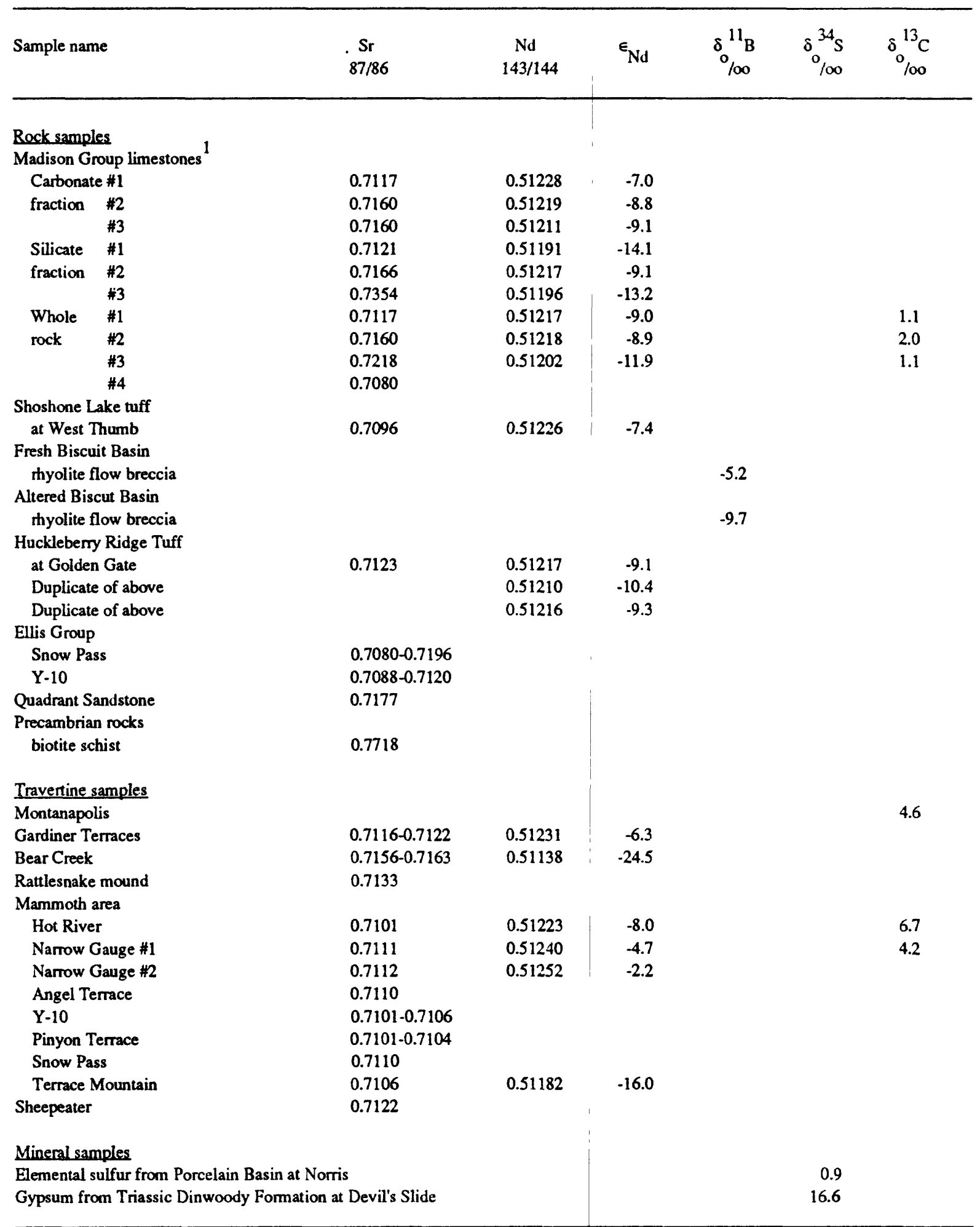

1 Madison Group limestones sample \#1 is from Hoppe Ranch near Bear Creek, \#2 is from Devil's Slide, \#3 is from near Tower Junction, and \#4 is from Pebbie Creek campground. 
Table F-6. Subsurface temperatures calculated from selected chemical geothermometers

[All temperatures reported in degrees Celsius $\left({ }^{\circ} \mathrm{C}\right)$ ]

\begin{tabular}{|c|c|c|c|c|c|c|c|c|}
\hline \multirow[b]{2}{*}{ Site } & \multirow{2}{*}{$\begin{array}{l}\text { Measured } \\
\text { Temp. } \\
{ }^{\mathrm{C}} \mathrm{C}\end{array}$} & \multicolumn{6}{|c|}{ Calculated temperature from chemical geothermometry } & \multirow{2}{*}{$\begin{array}{l}\text { Selected } \\
{ }^{\text {Temp. }}{ }^{1} \mathrm{C}\end{array}$} \\
\hline & & Quartz & Chalcedony & $\begin{array}{c}\mathrm{Na}-\mathrm{K}-\mathrm{Ca} \\
\pm \mathrm{Mg}\end{array}$ & $\mathrm{Mg}-\mathrm{Li}$ & $\mathrm{K}-\mathrm{Mg}$ & Anhydrite & \\
\hline Growler $^{2}$ & 93 & 255 & 249 & 284 & 323 & 283 & 315 & 300 \\
\hline Clearwater-3C & 93 & 216 & 201 & 246 & 228 & 195 & 250 & 240 \\
\hline Sheepeater & 73 & 136 & 109 & 109 & 95 & 96 & 200 & 100 \\
\hline Narrow Gauge & 72 & 116 & 87 & 82 & 82 & 86 & 105 & 90 \\
\hline$Y-10$ & 73 & 144 & 118 & 89 & 83 & 88 & 95 & 100 \\
\hline Bear Creek-1 & 32 & 95 & 64 & 81 & 49 & 79 & 88 & 70 \\
\hline La Duke & 68 & 116 & 87 & 76 & 45 & 67 & 85 & 80 \\
\hline CUT & 53 & 132 & 104 & 76 & 38 & 66 & 85 & 80 \\
\hline
\end{tabular}

${ }^{1}$ Uncertainties in selected temperatures are about $\pm 30^{\circ} \mathrm{C}$ for Growler and Clearwater-3C and $\pm 10{ }^{\circ} \mathrm{C}$ for all other sites.

2 Temperatures for Growler are calculated after multiplying the concentrations of solutes (table 5-1) by 0.8 to correct for boiling (see text). 
Table F-7. Calculated possible amounts of Mammoth-type thermal water in that of La Duke Hot Spring and Bear Creek-1.

$$
\text { [Reported in percent] }
$$

Chemical and Isotopic Parameters Used to

Calculate Percent Mixing

Hot Spring $\quad$ Cl $\quad$ B $\quad \delta^{11} \mathrm{~B} \quad$ Li $\quad \delta^{6} \mathrm{Li} \quad{ }^{3} \mathrm{He} /{ }^{4} \mathrm{He} \quad \delta \mathrm{D} \& \delta^{18} \mathrm{O} \quad$ Selected Value ${ }^{1}$

$\begin{array}{lllllllll}\text { La Duke Spring } & 21 & 10 & 2 & 15 & 10 & 0 & 0 & 0\end{array}$

$\begin{array}{lllllllll}\text { Bear Creek-1 } & 20 & 24 & 19 & 23 & 9 & 3 & 10 & 10\end{array}$

${ }^{1}$ Selected value for La Duke Hot Spring is based on values for ${ }^{3} \mathrm{He} /{ }^{4} \mathrm{He}, \delta^{11} \mathrm{~B}$, and water isotopes; that for Bear Creek-1 is based on solute and water isotopes (see text for details). 


\title{
CHAPTER G
}

\section{HYDROLOGIC INVESTIGATIONS IN THE CORWIN SPRINGS KNOWN GEOTHERMAL RESOURCES AREA AND ADJACENT PARTS OF YELLOWSTONE NATIONAL PARK}

\author{
By Michael L. Sorey, Elizabeth M. Colvard, D. A. Nimick, \\ R.R. Shields, J. J. Thordsen, and Gil Ambats
}

\section{Contents}

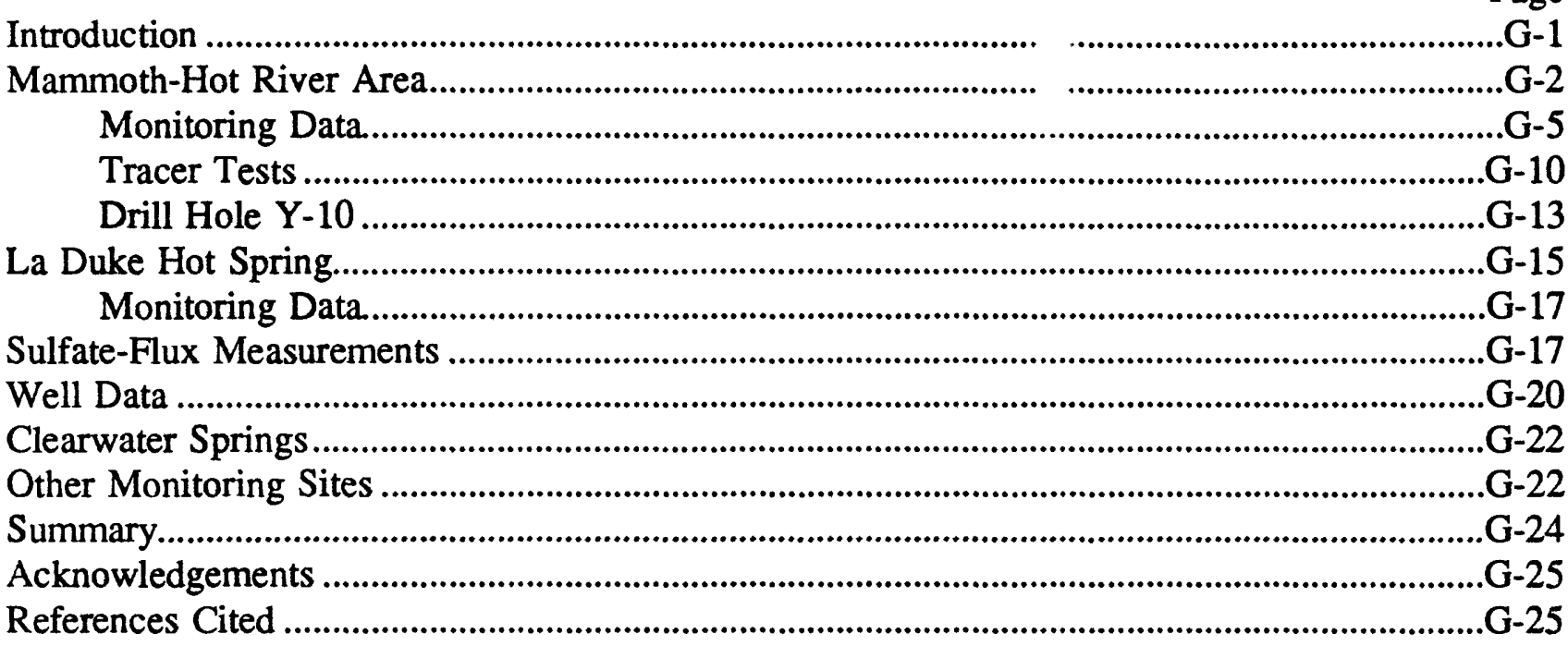

\section{Introduction}

Hydrologic aspects of our study included collection of data from existing thermal and nonthermal wells, establishment of monitoring sites at three thermal areas, and determinations of the total rate of thermal-water discharge in the Mammoth Hot River, La Duke, Bear Creek, and Clearwater Springs areas (fig. B-1). The available hydrologic data for the study area are limited. No data exist on hydrologic conditions below a depth of about $150 \mathrm{~m}$. The only measure of reservoir characteristics such as transmissivity (permeability times thickness) comes from the 1986 aquifer test on the CUT geothermal well near La Duke. No test-well drilling was done for this study. Thus, many of the techniques commonly used in hydrologic investigations to determine fluidflow directions and rates, such as water-level contour mapping and well interference tests, cannot be applied here. It has been possible to delineate certain aspects of the shallow ground-water circulation within specific areas, such as at Mammoth Hot Springs and La Duke Hot Spring, using tracer tests and measurements of water level and temperature in existing wells. But aside from quantifying differences in hydraulic head among various thermal areas, the nature of the flow systems that may connect these areas can only be inferred from more indirect information. 
As discussed below, tracer tests using a variety of injected chemicals established that there is a hydraulic connection between springs on the travertine terraces at Mammoth Hot Springs (Mammoth Terraces) and thermal water issuing at Hot River (fig. G-1). Ground water from both thermal and nonthermal sources flows from Mammoth to Hot River, covering a distance of about $2 \mathrm{~km}$ in 2-5 hours. This flow occurs through permeable channels in the continuous travertine deposit that is up to $100 \mathrm{~m}$ in thickness beneath the terraces at Mammoth, but thinner between the terraces and Hot River. The discharge at Hot River is thus derived from three sources: streamflow that enters sinkholes in the travertine, (2) hot-spring flow that seeps into sinkholes on the terraces, and (3) thermal water beneath the terraces or beneath areas west of the terraces that flows eastward, probably along the old ground surface buried by the travertine deposits. Hydraulic connections between Mammoth and thermal areas in the Corwin Springs KGRA cannot be tested by injected chemical tracers because ground-water velocities in even the most permeable sedimentary rocks between these areas are on the order of feet per day or less and hence travel times to reach the KGRA hot springs would be tens to hundreds of years or longer.

Measurements of stream flow, spring flow, and water chemistry were made periodically during the period 1988-1990 at three thermal areas - Clearwater Springs, Hot River and adjacent sections of the Gardner River, and La Duke Hot Spring (fig. B-1). Data on spring flow and chloride concentration at Hot River and La Duke Hot Spring collected in 1987 and 1988 by previous workers were also utilized in this study (Friedman and Norton, 1990; Norton and others, 1989). At Hot River, continuous records of spring temperature, specific conductance, and flow were obtained over most of the 1988-1990 period. The purposes of this monitoring effort, conducted jointly by the U.S. Geological Survey and the National Park Service, were to determine the natural level of variability in hot springs in these area and to assess the total rate of thermal-water discharge in each area. The total thermal-water discharge was determined from measurements of chemical flux in streams into which the hot springs drain.

Hydrologic data were collected from wells in the study area, including depth-to-water measurements, temperature-depth profiles, and fluid samples. Within the Park, three small-diameter thermal wells were drilled in the 1960's at Norris and Mammoth for research purposes by the U.S. Geological Survey (White and others, 1975). Wells Y-9 and Y-12 at Norris were not accessible for measurements and sampling during our study, but well Y-10 at Mammoth was. We also obtained data from three thermal wells in the La Duke area (the CUT geothermal well, the Miller thermal well, and the U'ren well), and from seven nonthermal wells in the Corwin Springs KGRA (fig. G-2).

\section{Mammoth-Hot River Area}

The principal thermal features within the Mammoth-Hot River area are the hot springs and research drill hole on the Mammoth Terraces and thermal springs along the Gardner River including Hot River (fig. G-1). Travertine deposits cover a total area of about $5 \mathrm{~km}^{2}$. Previous studies of this area involved measurements of spring flow and temperature, water chemistry, and geologic mapping of surficial deposits (Allen and Day, 1935; Thompson, 1975; and Bargar, 1978). A tracer test conducted in 1914, involving injection of $1 \mathrm{~kg}$ of fluorescein into a sinkhole at an unspecified location near the park headquarters and detection of fluorescein at Hot River two hours after injection (Dole, 1914), provided an indication of a hydrologic connection between these two areas. 

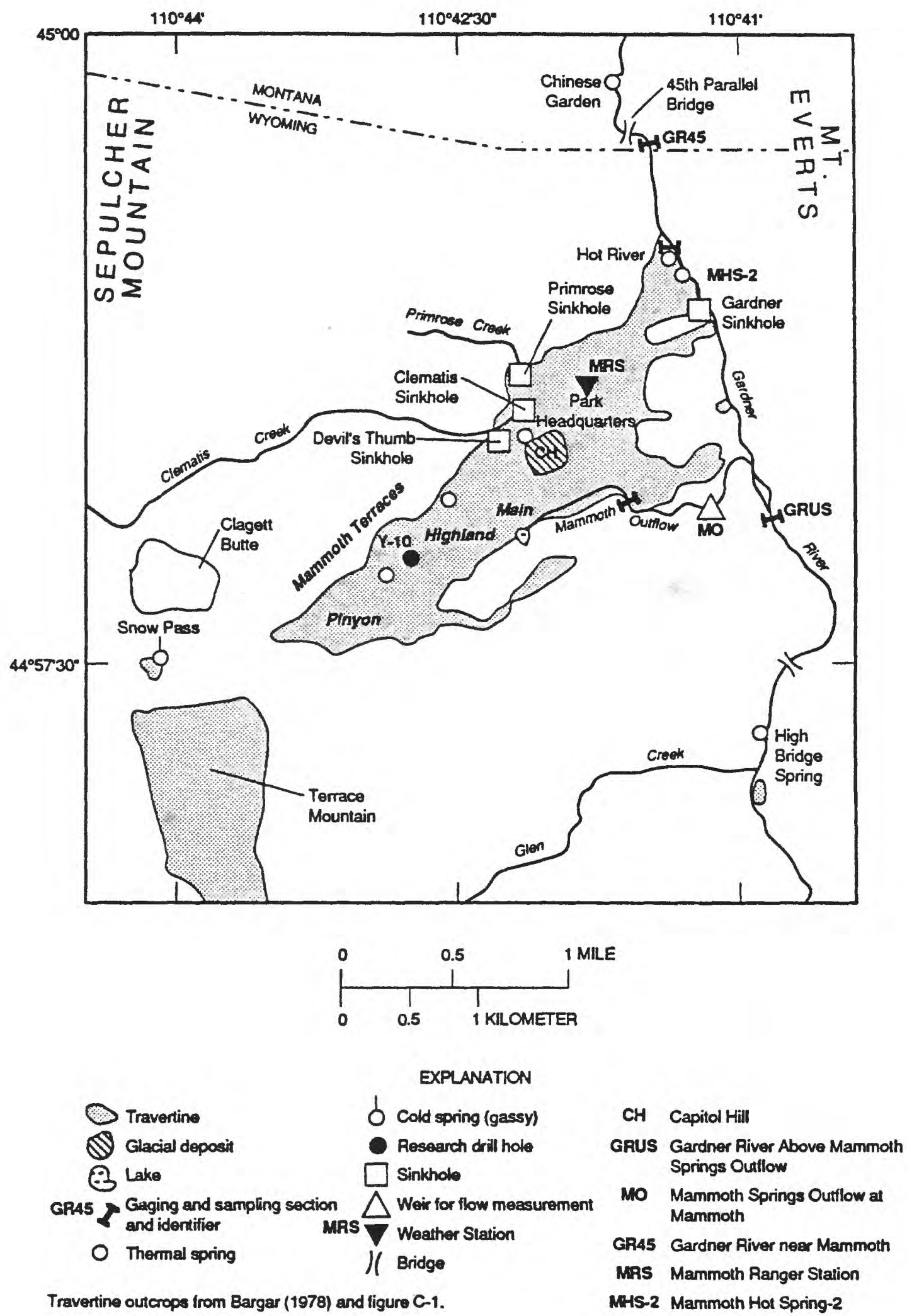

Figure G-1. Mammoth Hot Springs area in Yellowstone National Park showing locations of hydrologic monitoring sites, thermal features referred to in text, and outcrops of travertine. 


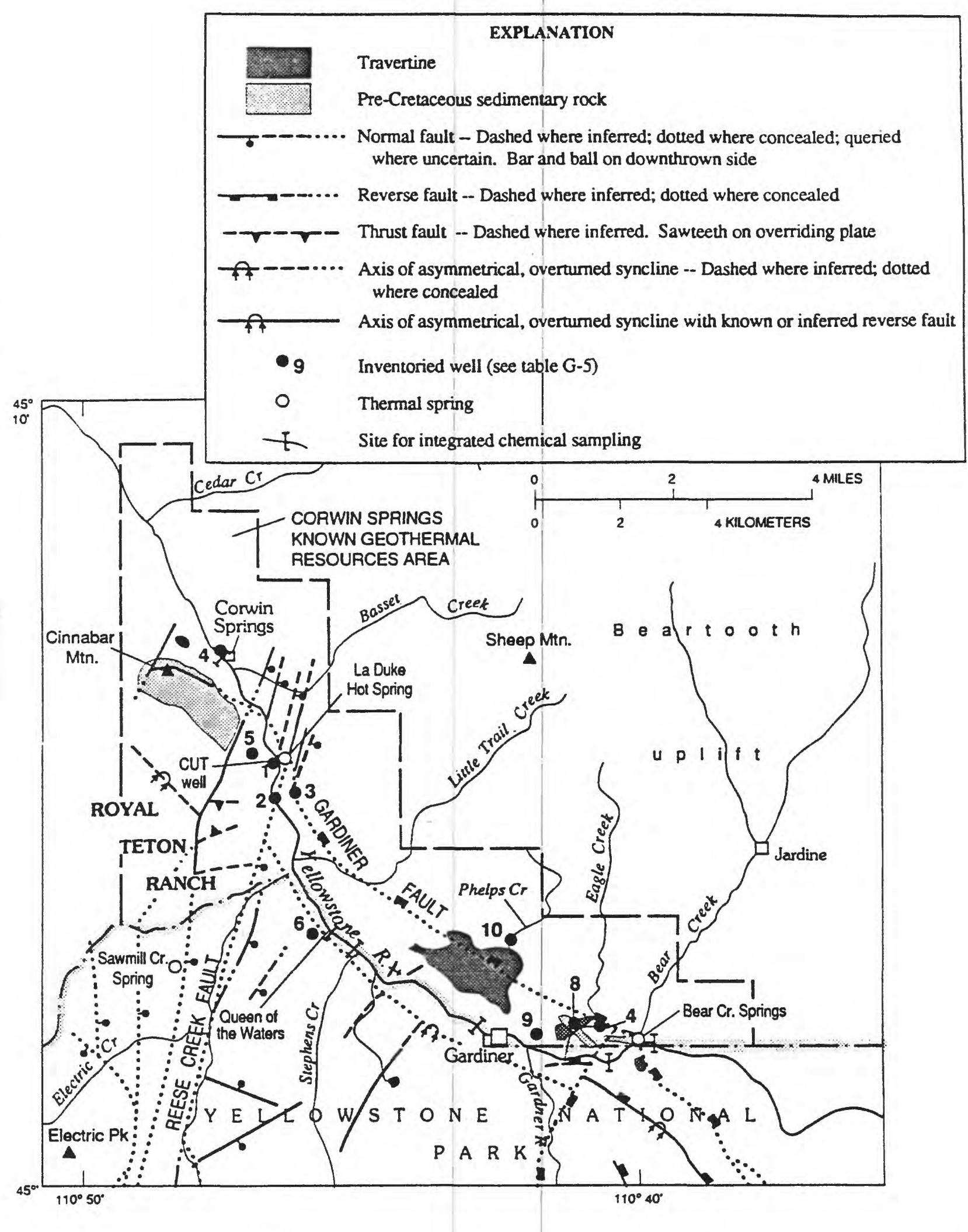

Figure G-2. Corwin Springs Known Geothermal Resources Area near Gardiner, Montana, and adjacent parts of Yellowstone National Park showing locations of thermal springs and thermal and nonthermal wells inventoried in this study, faults, and sites of integrated fluid sampling in the Yellowstone River. Outcrops of travertine and pre-Cretaceous sedimentary rocks from figure C-1 (Pierce and others, this volume). 
Allen and Day (1935) attempted to measure the total flow of the "Mammoth Springs" (hot springs on the travertine terraces above the park headquarters) using six weirs installed on streams draining the area. Their records show a consistent decline in the total surficial outflow of thermal water over the $1928-1932$ period from $72 \mathrm{~L} / \mathrm{s}$ to $15 \mathrm{~L} / \mathrm{s}$, which they attributed primarily to an increase in subsurface flow of thermal water to Hot River, or in their words "the lost spring water has found a lower outlet." The accuracy and limited number (4) of measurements of the flow of Hot River over this period preclude determining if there was an increase in the flow of Hot River coincident with the decline in spring flow at Mammoth Springs. Allen and Day (1935) estimated that in the summer of 1932 approximately 60 percent of the total flow of Mammoth Springs seeped back into the ground before reaching the weirs. Their estimate of the total flow of Mammoth Springs at this time, adjusted for this seepage, was $39 \mathrm{~L} / \mathrm{s}$. Thus, part of the apparent decline in spring flow over the 1928-1932 period is accounted for by an increase in seepage that reduced the surficial outflow of thermal water from the terraces.

Allen and Day argued against the decline in Mammoth Springs being caused by the effects of below-normal precipitation because the temperature of springs on the terraces remained relatively constant. Friedman and Norton (1990) hypothesize that climate-related changes in the local watertable elevation influence the rate of outflow of thermal springs in the Mammoth-Hot River area as well as in some other thermal areas within the park and that changes in spring temperature would not be expected to accompany variations in spring flow. Observations of the discharge characteristics of hot springs and ages of travertine deposits at Mammoth clearly indicate a tendency for continual change in the location and flow rate of individual vents (Bargar, 1978) and a general lowering of the elevation of outlets of active springs over the past 10,000 years (Pierce and others, this volume).

\section{Monitoring Data}

We monitored the total rate of outflow of thermal water from the Mammoth Hot Springs system over the 1988-1990 period utilizing measurement sites on Hot River, Mammoth Outflow, and sites on the Gardner River upstream and downstream from the areas of thermal-water inputs (fig. G-1). Additional measurements of streamflow were collected on Clematis Creek and on the sinkhole on the west bank of the Gardner River upstream from Hot River (referred to here as the Gardner sinkhole). The only thermal water not accounted for with this group of measurement sites is that lost by evaporation below spring vents on the terraces and a small discharge from seeps along the Gardner River at Chinese Garden, located $670 \mathrm{~m}$ downstream from the gaging station near the 45th parallel bridge. Measurements in February 1990 indicated a total flow of 10-15 L/s of Mammoth-type water $(170 \mathrm{mg} / \mathrm{L} \mathrm{Cl})$ from the Chinese Garden area. Temperatures as high as $26^{\circ} \mathrm{C}$ have been measured in sloughs on both sides of the river (Hamilton and Chambers, this volume), but water samples from the sloughs are diluted by river water.

Only that part of the spring discharge on the Mammoth Terraces that flows on the surface to the Gardner River was measured during this study. This flow, referred to here as the Mammoth Outflow, drains the south side of Main Terrace and moves toward the Gardner River along the south side of the travertine outcrop (fig. G-1). Discharge measurements on the Mammoth Outflow during this study were made at a weir located $0.75 \mathrm{~km}$ upstream from the confluence of this flow with the Gardner River. This site is designated "Mammoth Springs outflow at Mammoth" in USGS stream 
gaging records. Six additional flow measurements were made in 1986 and 1987 at a site $0.9 \mathrm{~km}$ further upstream. The monitoring data for Mammoth Outflow (fig. G-3 and table G-1) show a near constant chloride concentration of $170 \pm 3.9 \mathrm{mg} / \mathrm{L}$ (standard deviation) but a discharge ranging from 20 to $104 \mathrm{~L} / \mathrm{s}$. This chloride concentration is close to the average value obtained from analyses listed by Kharaka and others (this volume) for samples from well Y-10 and Narrow Gauge Spring. Thus the plot of total discharge for Mammoth Outflow is essentially the same as the plot of thermalwater discharge (calculated as discharge times chloride concentration divided by an assumed thermal-water chloride concentration of $170 \mathrm{mg} / \mathrm{L}$ ). The average value of thermal-water discharge for Mammoth Outflow for the $1986-1990$ period is $43 \mathrm{~L} / \mathrm{s}$, with a relative standard deviation (RSD) of 47 percent. Note that discharge values measured in 1986 and early 1987 are above this mean value and exceed the maximum value obtained by Allen and Day (1935) for total hot-spring outflow from Mammoth Springs $(72 \mathrm{~L} / \mathrm{s})$.

Monitoring data for Hot River (fig. G-4 and table G-2) show the effects of variable mixing of thermal and nonthermal components which produces an inverse relation between flow and chloride concentration. The thermal component is diluted by inputs of nonthermal water from the Gardner River through the Gardner sinkhole, and Clematis and Primrose Creeks through sinkholes near the park headquarters. River water probably began re-entering the Gardner sinkhole following a debris flow off the flank of Mt Everts in the spring of 1987, which shifted the river channel to the west. The sinkhole was originally produced by much earlier debris-flow damming (W.L. Hamilton and P.J. Conn, National Park Service, written commun., 1989). Direct measurements of flow into this sinkhole have been possible on some occasions; values range from 88 to $324 \mathrm{~L} / \mathrm{s}$. Tracer tests, discussed below, have established that this inflow reaches and exits from Hot River in about 20 minutes. Periods of abrupt decline in discharge (and rise in chloride) at Hot River occur each winter at times when the channel supplying water to the sinkhole freezes. The discharge of Hot River also increases each spring and summer when Clematis and Primrose Creeks flow into sinkholes near the Park Headquarters. Clematis Creek was gaged periodically in 1989 and 1990; measured flows ranged from 0-85 L/s. Visual estimates suggest the flow of Primrose Creek is approximately 30 percent as large as the flow of Clematis Creek.

A continuous monitoring system was established at the Hot River site to record both short and long-term variations in discharge characteristics. Stage was recorded on a strip chart; temperature and specific conductance were measured and recorded digitally initially at 15-minute intervals and then at 1 hour intervals. A correlation was established between specific conductance and chloride concentration from periodic fluid samples that permitted the discharge and conductance records to be converted to a continuous record of chloride flux, following methods outlined by Farrar and others (1985). The conductance, temperature, and discharge records for part of 1989 (fig. G-5) show consistent changes in all three properties related to variations in inputs of nonthermal water from sinkholes. As the nonthermal input decreases, discharge decreases and temperature and specific conductance increase. Such changes can happen abruptly because of the short travel time from the sinkholes. Future changes in the discharge characteristics of Hot River should be expected due to variations in the flow of the Gardner River and Clematis and Primrose Creeks, clogging of sinkhole orifices from sediment and debris, and debris flows that change the course of the Gardner River.

Thermal-water discharge for Hot River is calculated from the chloride flux divided by 170 $\mathrm{mg} / \mathrm{L}$, as discussed above. This calculation ignores the relatively minor chloride flux contributions 

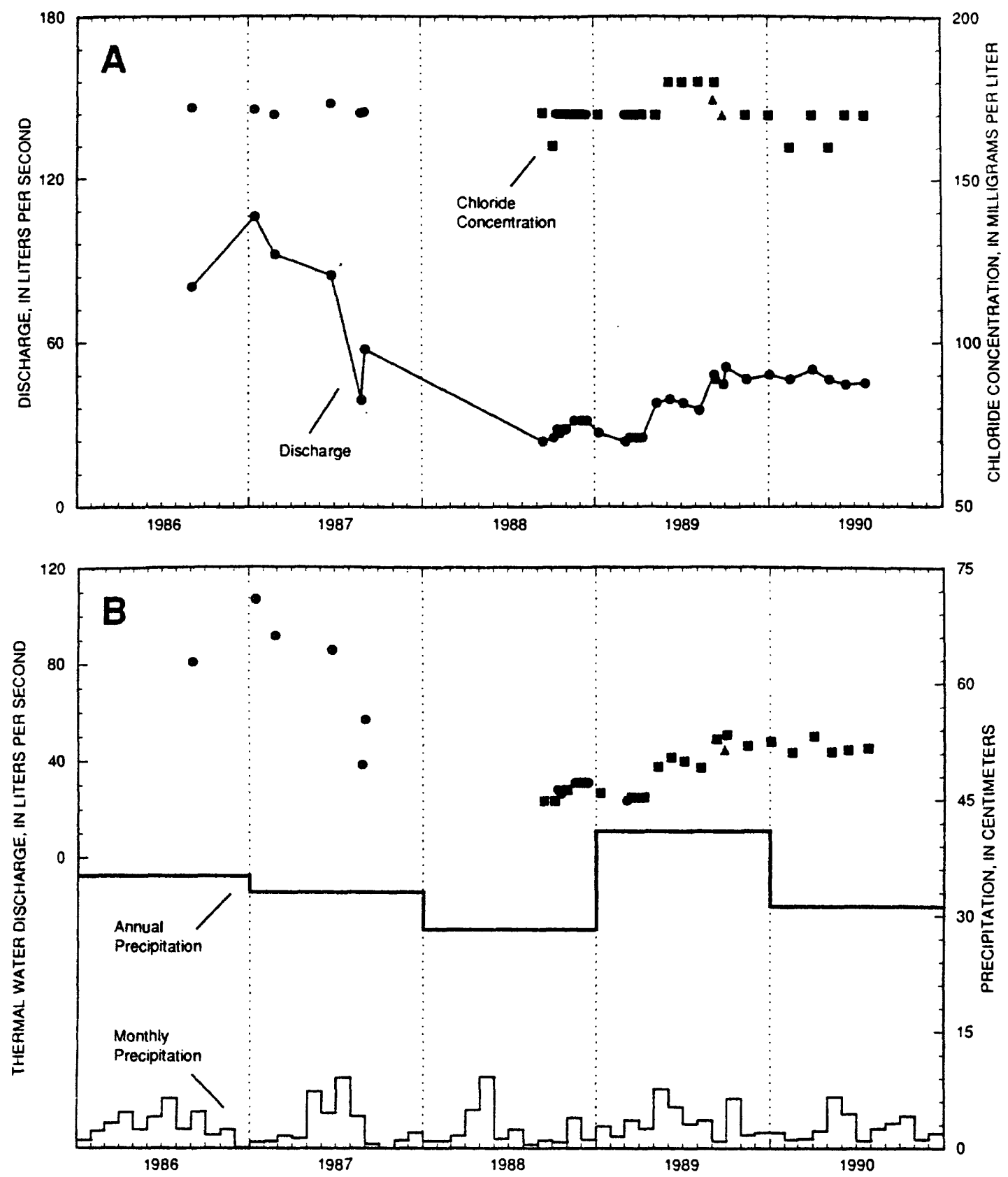

EXPLANATION

- U.S. Geological Survey Central Laboratory, Arvada, Colorado.

- - U.S. Geological Survey Central Laboratory, Arvada, Colorado (values corrected by D.R. Norton based on results for chloride standards).

$\Delta$ - U.S. Geological Survey laboratory, Menlo Park, California, under the direction of Y.K. Kharaka.

Thermal-water discharge $=$ total discharge $\mathrm{x}$ chloride concentration $/ 170$ milligrams per liter .

Figure G-3. Discharge and chloride concentration (A) and calculated thermal-water discharge for Mammoth Outflow (site name Mammoth Outflow springs at Mammoth) and precipitation record at Mammoth Ranger Station (B), 1986-90. 

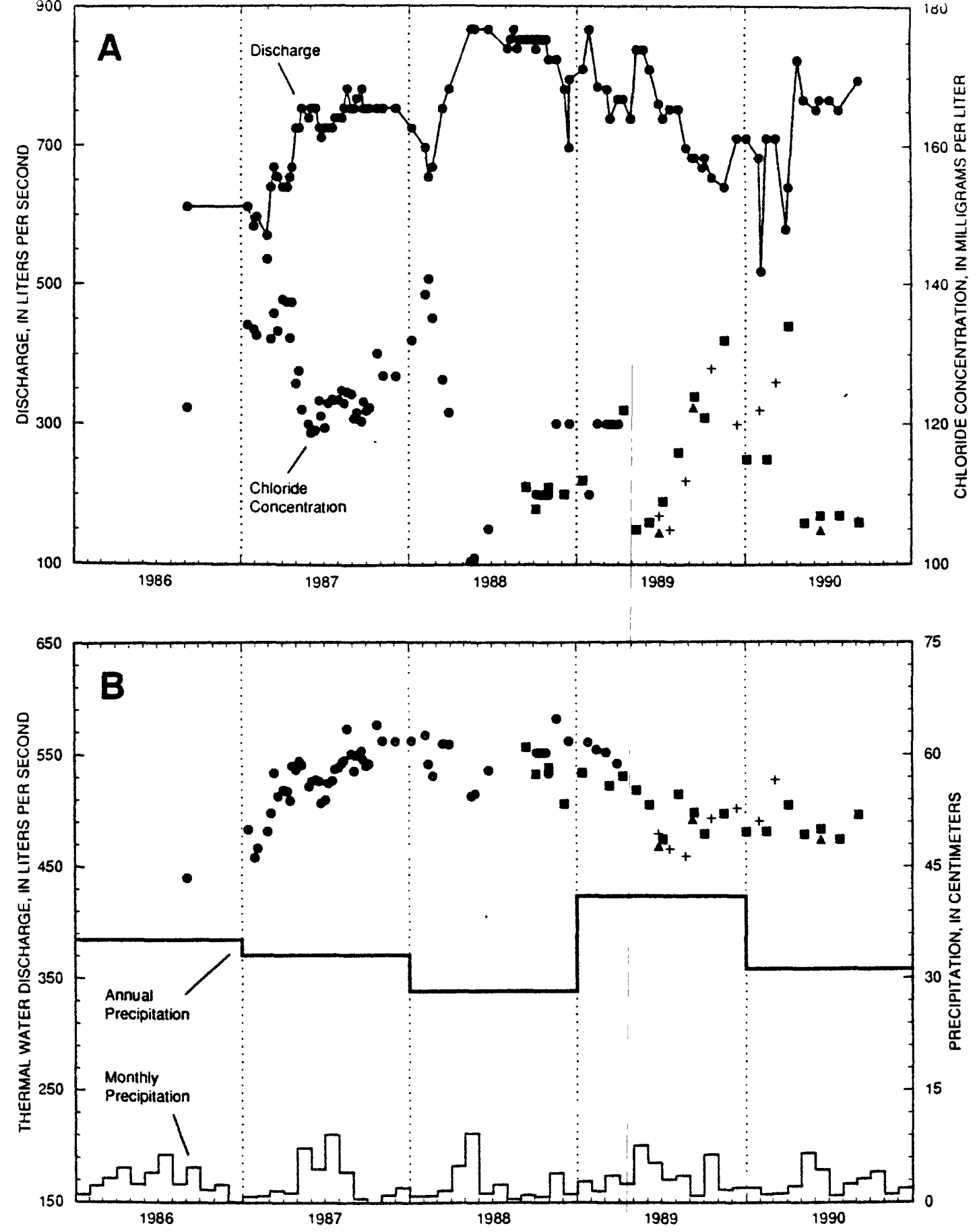

EXPLANATION

- U.S. Geological Survey Central Laboratory, Arvada, Colorado.

- U.S. Geological Survey Central Laboratory, Arvada, Colorado (values corrected by D.R. Norton based on results for chloride standards).

$\Delta$ - U.S. Geological Survey laboratory, Menlo Park, California, under the direction of Y.K. Kharaka.

+ - U.S. Geological Survey laboratory, Menlo Park, California, under the direction of W.C. Evans.

Thermal-water discharge $=$ total discharge $\mathrm{x}$ chloride concentration $/ 170$ milligrams per liter .

Figure G-4. Discharge and chloride concentration (A) and calculated thermal-water discharge for Hot River (site name Hot River at Mammoth) and precipitation record at Mammoth Ranger Station (B), 1986-90. 
from the Gardner sinkhole and Clematis and Primrose Creeks (less than 2 percent). The level of variability in thermal-water discharge at Hot River is indicated by computing the relative standard deviation (RSD) about the mean value $(522 \mathrm{~L} / \mathrm{s})$. The RSD for total thermal-water discharge (6 percent) is significantly less than the RSD for the variations in total discharge (10 percent). In fact the thermal-water discharge RSD is approximately equal to that expected from errors in streamflow and chloride concentration determinations, suggesting that the observed variability could be entirely due to measurement errors. However, consistent patterns of annual and seasonal changes in thermalwater discharge are apparent (fig. G-4), as is an inverse correlation with the annual precipitation at Mammoth. This suggests that there may be an influence on thermal-water discharge in Hot River from variations in the shallow water table or recharge of nonthermal water to the travertine beneath the Mammoth terraces.

Streamflow and chloride concentration data for sites on the Gardner River upstream and downstream from Hot River and the Mammoth Outflow were used to calculate differences in chloride flux between these sites as a measure of the total input of thermal water from the Mammoth system to the Gardner River above the 45th parallel bridge (site Gardner River near Mammoth). If there are no unseen inputs or losses of thermal water, the sum of chloride flux from Hot River and Mammoth Outflow should be approximately equal to the difference noted above. Our records show this to be the case (fig. G-6), although the level of variability in the chloride-flux determinations for the Gardner River sites is considerably greater than for the Hot River and Mammoth Outflow sites. This reflects greater error in streamflow determinations and integrated sampling for the Gardner River sites. In general, the sum of the $\mathrm{Cl}$ flux from Hot River and Mammoth Outflow is greater than the difference in flux in the Gardner River, suggesting a tendency for loss of thermal water from the river. The average chloride flux from Hot River and Mammoth Outflow $(95 \pm 4.7 \mathrm{~g} / \mathrm{s})$ implies a total thermal-water discharge of $560 \mathrm{~L} / \mathrm{s}$.

Chloride-flux measurements were made at two sites in the Gardner River, downstream from the 45th parallel bridge in September 1989 and June 1990 (table G-4). A small increase in flux was calculated for both sets of data, indicating inputs of Mammoth-type thermal water of 22-32 L/s. Based on our February 1990 measurements of thermal-spring flow at Chinese Garden noted previously, approximately half of this thermal-water input occurs at Chinese Garden and half occurs between Chinese Garden and the confluence with the Yellowstone River.

The total thermal-water outflow from the Mammoth-Hot River system is therefore close to 590 L/s. A reasonable estimate of the total flow of hot springs on the Mammoth Terraces is given by the average flow of the Mammoth Outflow stream (43 L/s) plus an additional $20 \mathrm{~L} / \mathrm{s}$ assumed to discharge from springs in other parts of the area but seep back into the travertine. This indicates that approximately 10 percent of the total outflow from this system occurs as hot-spring flow on the terraces. The significance of the total flow rate and the associated convective heat output in delineating the sources of fluid and heat for the Mammoth system are discussed in the next section of the report.

\section{Tracer Tests}

Organic and inorganic tracers were injected at several sites in the Mammoth area and along the Gardner River in tests run in 1989 and 1990. Inorganic tracers included fluorescein, rhodamine 

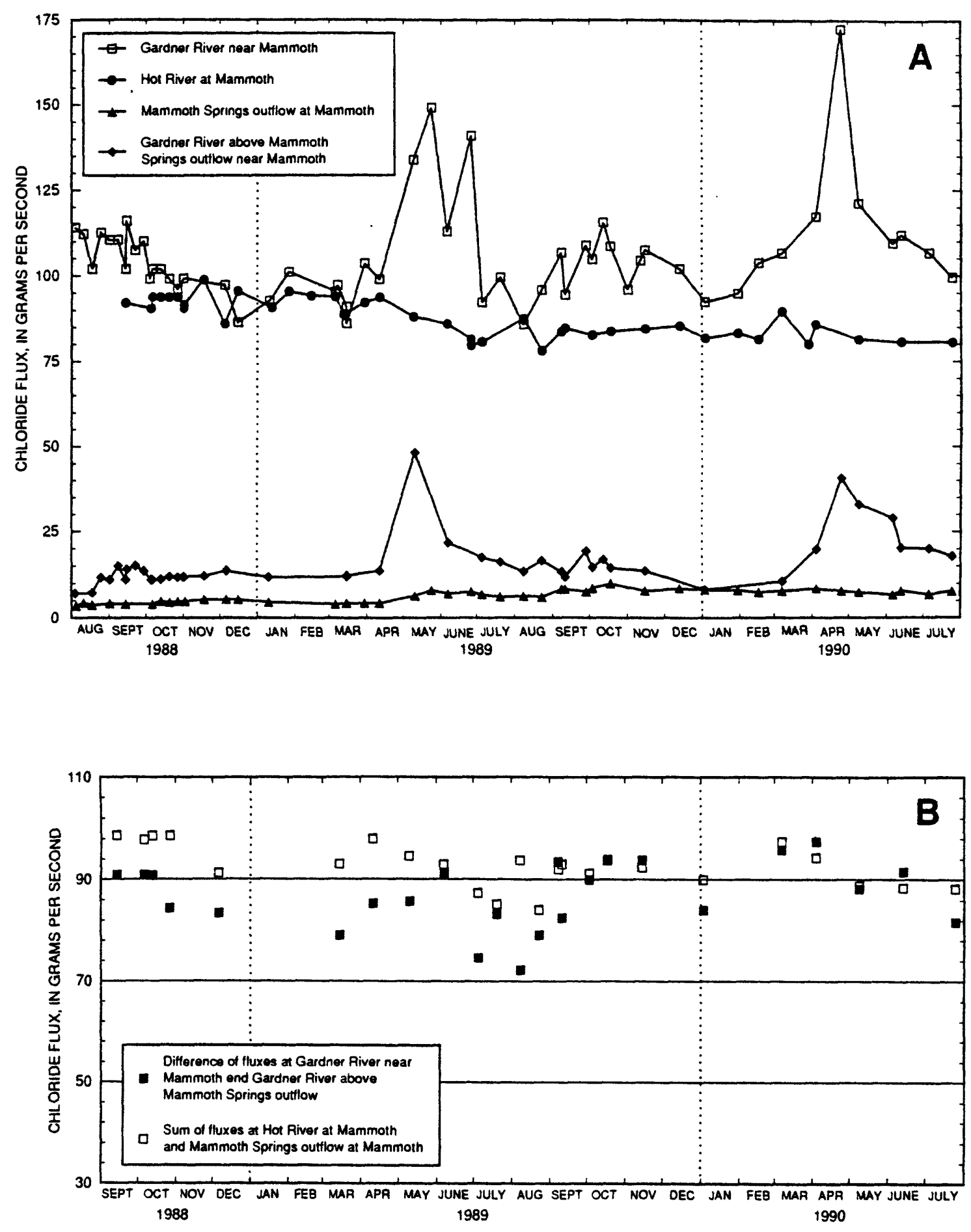

Figure G-6. Chloride-flux values at four sites along or adjacent to the Gardner River below Mammoth Hot Springs (A), and the sum of chloride flux at Hot River and Mammoth Outflow and the difference between chloride flux at Gardner River near Mammoth and Gardner River above Mammoth Springs outflow near Mammoth (B), September 1988-July 1990. 
WT, and bromide; organic tracers included acetic acid, benzoic acid, phenol, alanine, glycine, and t-butyl alcohol. Injection and sampling of organic tracers were done by David R. Janecky and his colleagues from Los Alamos National Laboratory, Los Alamos, New Mexico. The purpose of the tracer work was to delineate hydraulic connections and travel times for thermal and nonthermal ground water between the Mammoth Terraces, Hot River, and other sites along the Gardner River. Comparisons of results for different tracers provide information on chemical reactivity of different tracers with rocks along the flow paths. Results of the 1990 tracer work are presented by Janecky and others (1991); results of the 1989 are unpublished.

Sampling and analytical methodologies were generally similar to those described by Smart and Laidloaw (1977) and Kilpatrick and Cobb (1984). One significant modification of methodology was required in the case of fluorescein analyses in order to obtain accurate concentrations. It involved addition of $\mathrm{HCl}$ solution and stirring to lower the $\mathrm{pH}$ of each water sample to values between 2 and 3 in order to expel $\mathrm{CO}_{2}$ gas. This was followed by addition of $\mathrm{NaOH}$ solution to raise the $\mathrm{pH}$ of the sample to values between 9 and 10 prior to fluorescein analysis. The standards, which were obtained from the tracer stock solutions immediately before injection, were treated in a similar manner.

Tracers were injected in sinkholes near the Park Headquarters at Mammoth, in the Gardner sinkhole upstream from Hot River, and directly into the Gardner River at the upper foot bridge (fig. G-1). The Clematis sinkhole drains the total flow of Clematis Creek into the travertine section; the Devil's Thumb sinkhole drains thermal water flowing off the northern side of the Main Terrace. During tests involving injection into Devil's Thumb sinkhole, samples collected at Opal Terrace, located $200 \mathrm{~m}$ to the east, showed no evidence of tracer discharge.

The principal findings of the tracer tests are summarized below.

1. Subsurface flow paths connect Devil's Thumb and Clematis sinkholes to Hot River and to thermal-spring vents at MHS-2 and Chinese Garden (fig. G-1).

2. There are no hydraulic connections between Devil's Thumb sinkhole and Opal Terrace and between the Gardner sinkhole and MHS-2.

3. A hydraulic connection does exist between Clematis sinkhole and MHS-2.

4. Travel times, based on the first appearance of tracer, from Clematis and Devil's Thumb sinkholes to Hot River and MHS-2 are about 2 and 3.5 hours, respectively. The travel time from the Gardner sinkhole to Hot River is about 30 minutes.

5. The longer travel time between Devil's Thumb sinkhole and Hot River compared with that from Clematis sinkhole, is probably due mainly to a smaller rate of surface-water discharge entering the Devil's Thumb sinkhole. The patterns of tracer concentrations as a function of time indicate the presence of at least one relatively large subsurface pool and secondary flow channels between Devil's Thumb sinkhole and Hot River.

6. Approximately 60-65 percent of the fluorescein and 48-54 percent of the rhodamine WT injected at the Mammoth Terraces were recovered at sites along the Gardner River, compared with almost 100 percent of the injected $t$-butyl alcohol. Differences in recovery percentages are due to differences in the chemical reactivities of these compounds and not to physical loss of thermal water in the subsurface.

7. The tracer tests show that over 90 percent of the water entering Devil's Thumb and Clematis sinkholes emerges at Hot River. 
Subsurface flow between Devil's Thumb sinkhole and thermal springs at Chinese Garden involves somewhat longer travel times than flow between this sinkhole and Hot River and MHS-2. Tracer breakthrough at Chinese Garden occurred approximately 9 hours after that at Hot River. Tracer flow to Chinese Garden appears to be more dispersed than tracer flow to Hot River because tracer concentrations remained above those in Hot River at least as long as 75 hours after injection when the last sample was collected. This observation is consistent with a longer pathway and smaller total flow from Mammoth Terraces to Chinese Garden than from Mammoth Terraces to Hot River. Chinese Garden is located $1.3 \mathrm{~km}$ downstream from the northernmost occurrence of travertine that connects the Mammoth Terraces with the Gardner River. Thus, a flow path connecting the Mammoth Terraces with Chinese Garden must exist, in part, outside the travertine section. Such flow is unlikely to occur only in river-channel sediments beneath the bed of the Gardner River because it would be cooled by the river, whereas temperatures as high as $26^{\circ} \mathrm{C}$ have been measured in the sloughs adjacent to the river at Chinese Garden.

\section{Drill Hole Y-10}

Research drill hole Y-10 was completed in 1967 to a depth of $101 \mathrm{~m}$ at Bath Lake (White and others, 1975), located $1.2 \mathrm{~km}$ southwest of the park headquarters on Highland Terrace (fig. G-1). The lithologic section in Y-10 includes $77 \mathrm{~m}$ of travertine with interbedded clastic deposits around $55 \mathrm{~m}$ and $70 \mathrm{~m}$, underlain by sedimentary rocks of Mesozoic age (fig. G-7). Temperature measurements made during drilling with maximum-reading thermometers (White and others, 1975) and during our study with borehole logging equipment indicate a maximum temperature of $72^{\circ} \mathrm{C}$ and nearly isothermal conditions below a depth of $17 \mathrm{~m}$. Spinner logs run with the well shut-in in May 1990 showed that these temperature conditions result in part from water flowing up the borehole and leaking out at depths of about $26 \mathrm{~m}$ (near the bottom of the casing) and $17 \mathrm{~m}$ (within the cased section of the hole). The rate of leakage at both zones is about $0.3 \mathrm{~L} / \mathrm{s}$. Wellheadpressure measurements made during drilling indicate that hydraulic head increases with depth at this location, most significantly below the travertine section (White and others, 1975). Chemical analyses show that fluids produced from $\mathrm{Y}-10$ are concentrated in $\mathrm{Cl}$ and $\mathrm{SO}_{4}$ by about 10 percent compared with hot-spring water discharging on the terraces. Taken together, these observations suggest that thermal-fluid discharge at Mammoth and Hot River is derived from upflow through Mesozoic and older sedimentary rocks underlying the travertine section. Possible locations for zones of upflow are discussed in other sections of the report. Access within Y-10 is currently restricted below a depth of about $55 \mathrm{~m}$, probably by calcite-cemented sediments. This is above the depth at which $\mathrm{CO}_{2}$ and other gases begin to exolve from the thermal fluid. Thus, attempts made during this study to obtain downhole fluid samples for analysis of dissolved gases under undisturbed reservoir conditions were not fully successful.

Shut-in wellhead pressure in Y-10 is currently 3.9 bars $(\mathrm{g})$; shut-in pressures as high as 5.3 bars (g) were measured in 1969 (White and others, 1975). These pressures reflect a gas cap that depresses the water level in the hole to unknown depths below the casing. A minimum estimate of the elevation of the piezometric surface corresponding to the hydraulic head in permeable zones tapped by this well can be obtained from the measured wellhead pressure when the well is flowing (2.4 bars-gage). This pressure corresponds with a height of water of approximately $25 \mathrm{~m}$ above land surface, or an elevation of $2081 \mathrm{~m}$. For comparison, the elevation of Narrow Gauge Spring on the Mammoth Terraces $650 \mathrm{~m}$ northeast of Y-10 (fig. G-1) is 2,003 m and that of Hot River is 1,732 


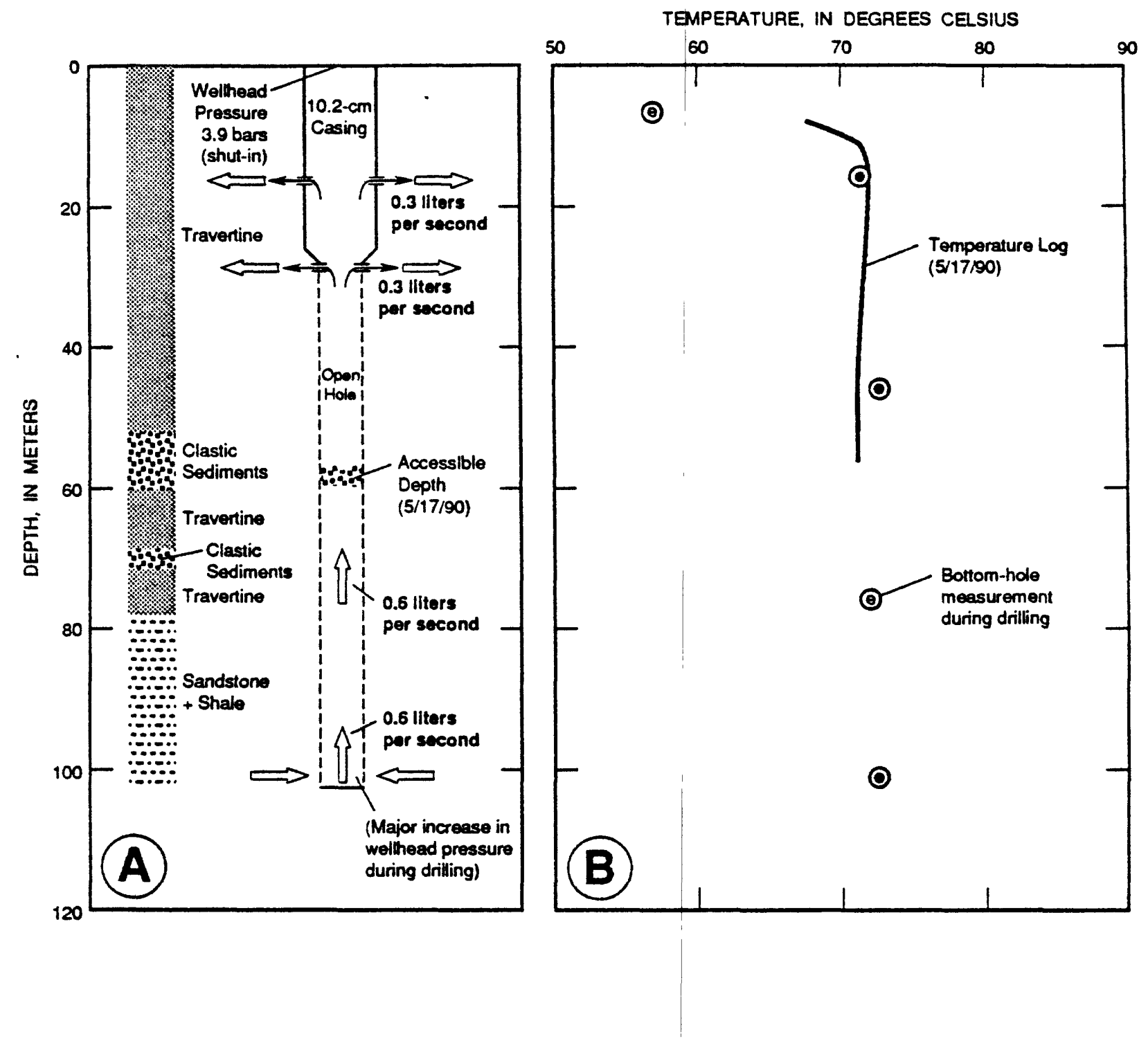

Figure G-7. Well construction, lithologic, and flow-meter data (A) and temperature data (B) for well Y-10 at Mammoth Hot Springs. Arrows indicate directions of fluid flow under shut-in conditions as determined from spinner surveys run May 19, 1990. Lithology from White and others (1975). 
$\mathrm{m}$. These differences in head result in the general flow of thermal water upward into the travertine section and northeastward towards discharge points along the Gardner River.

\section{La Duke Hot Spring}

La Duke Hot Spring issues from a concrete spring box on the east side of Highway 89, flows under the highway through a concrete culvert, then empties into the Yellowstone River. A travertine apron has developed on the stream bank over which the hot water flows to the river. Several other such travertine deposits occur near La Duke Hot Spring, indicating hot-water discharge at these locations in the past. La Duke Hot Spring has a long history of development and use. In 1902, Julius La Duke diverted the spring into a pool for bathing and swimming. In 1908, the Electric Hotel Company built a resort hotel at the town of Corwin Springs, $2.4 \mathrm{~km}$ north of La Duke, and piped water from La Duke to supply the hotel pool and provide heat for the building. The hot spring was used in this way on an intermittent basis until sometime after World War II, when the wooden pipeline from La Duke to Corwin Springs became too old for use.

No measurements or estimates of the flow of $\mathrm{La}$ Duke Hot Spring are available before visual estimates of 8.3 and $13.7 \mathrm{~L} / \mathrm{s}$ were made in 1975 and 1976, respectively, by U.S. Geological Survey personnel (Mariner and others, 1976; Leonard and others, 1978). The latter estimate may have included the flow of a second spring on the east side of the highway that drains into the outflow from La Duke before crossing under the highway. A measured flow of $2.3 \mathrm{~L} / \mathrm{s}$ was determined in September 1986 by U.S. Geological Survey personnel. Measurements made in May 1987 using a siphon to lower the level of water in the spring box show that the outflow from the spring box increases as the level of the outlet decreases (Hydrometrics, 1987). The flow out of the south side of the box ranged from $4.0 \mathrm{~L} / \mathrm{s}$ to $9.5 \mathrm{~L} / \mathrm{s}$ as the water level was lowered from the top of the box to a depth of $0.9 \mathrm{~m}$. The latter level may be comparable to the level that existed prior to the 1980 's when the outflow discharged from the north end of the box (Hydrometrics Consulting Scientists and Engineers, Helena, Montana, written commun., 1987). A pipe was installed near the base of the south side of the box during the summer of 1987 to maintain a relatively low water level in the box and a relatively high rate of outflow. Measurements of the rate of outflow by the Water Resources Division of the U.S. Geological Survey were begun in September 1987 using a $60^{\circ}$ V-notch weir installed in the outflow channel on the west side of highway. Since that time, the outflow from La Duke has ranged from a low of $5.2 \mathrm{~L} / \mathrm{s}$ to a high of $8.8 \mathrm{~L} / \mathrm{s}$ (fig. G-8).

The Church Universal and Triumphant (Royal Teton, Ltd.) currently holds temporary water right decrees from the Montana Water Court totalling $328 \mathrm{~L} / \mathrm{s}$ from La Duke Hot Spring (Water Rights Bureau, Montana Department of Natural Resources and Conservation, written communication, 1990). Other groups have applied for water rights to La Duke, but those of the Royal Teton, Ltd. predate these applications. The decreed amount is far in excess of the actual flow of the spring. As discussed below, however, the total flow of thermal water from springs and seeps adjacent to the Yellowstone River in the vicinity of La Duke $(61 \mathrm{~L} / \mathrm{s})$ is considerably greater than the flow of La Duke Hot Spring itself. The CUT geothermal well is capable of sustained production at rates near $25 \mathrm{~L} / \mathrm{s}$ (Hydrometrics, 1986). 

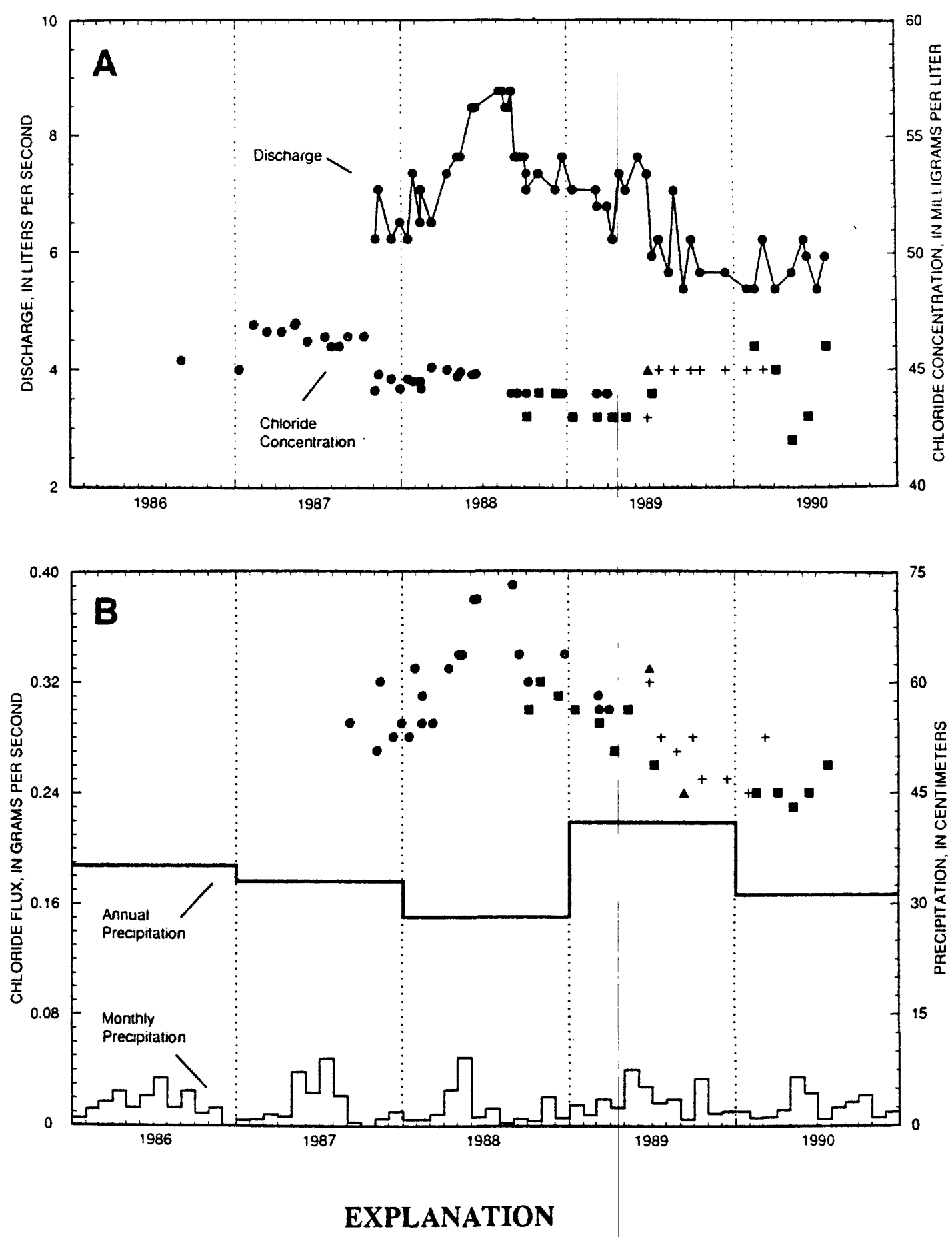

- U.S. Geological Survey Central Laboratory, Arvada, Colorado.

- - U.S. Geological Survey Central Laboratory, Arvada, Colorado (values corrected by D.R. Norton based on results for chloride standards).

$\Delta$ - U.S. Geological Survey laboratory, Menlo Park, California, under the direction of Y.K. Kharaka.

+ - U.S. Geological Survey laboratory, Menlo Park, California, under the direction of W.C. Evans.

Figure G-8. Discharge and chloride concentration (A) and chloride flux for La Duke Hot Spring (site name La Duke Hot Spring near Corwin Springs, Montana) and precipitation record from Mammoth Ranger Station (B), 1986-90. The Mammoth Ranger Station site is shown in figure G-1. 


\section{Monitoring Data}

Data collected on the discharge characteristics of La Duke Hot Spring since 1987 (fig. G-8 and table G-3) show that the flow rate has been variable (RSD $=15$ percent) while the $\mathrm{Cl}$ concentration has remained relatively constant $(\mathrm{RSD}=3.3$ percent). Consequently, the plot of $\mathrm{Cl}$ flux (fig. G-8) is similar to that of flow rate. The average value of flow from La Duke Hot Spring for the period 1987-1990 is $6.9 \mathrm{~L} / \mathrm{s}$. Variations in this flow represent a larger fraction of the average flow than for Hot River, and exceed the variation expected from measurement error (RSD $=6$ percent). There is a suggestion in the two complete-year record that hot-spring flow may increase in the summer as the stage and flow of the Yellowstone River increase. There may in fact be a dynamic balance between thermal-water flow from La Duke Hot Spring and flow from hot-spring vents located near river level, upstream and downstream from La Duke Hot Spring. Although many of these vents are under water at high river stage, there have been three attempts to estimate the total flow of these bank springs and La Duke Hot Spring. Estimates of 5 and $19 \mathrm{~L} / \mathrm{s}$ were obtained by Hydrometrics in May 1988 and January 1988, respectively. USGS personnel estimated total flow at $13 \mathrm{~L} / \mathrm{s}$ in February 1990. The higher estimates correspond with times of lower river stage and exceed the measured flow of La Duke itself. We postulate that the proportions of thermal water discharging in La Duke and in these river-level springs vary with river stage - more flow at La Duke and less in the river-level springs at high river stage, and conversely. The existing data base is not sufficient to confirm this, however.

Several zones of thermal-water discharge along the banks of the Yellowstone River in the vicinity of La Duke Hot Spring have been detected by temperature measurements of $37^{\circ}$ to $44^{\circ} \mathrm{C}$ at shallow depth $(2-10 \mathrm{~cm})$ in streambed sediments (fig. E-8, Hamilton and Chambers, this volume). The upstream zone, and possibly the downstream zone, is aligned with a segment of the Reese Creek fault system. Thermal springs and seeps in these zones occur on both banks of the river with measured temperatures of $32^{\circ}$ to $57^{\circ} \mathrm{C}$. The chemical composition of water sampled from springs in each zone is very similar to that of La Duke Hot Spring and water produced from the CUT geothermal well. These data, along with the measured temperature profile (fig. G-9) and lithologic data (Pierce and others, this volume) for the geothermal well, indicate that thermal water is leaking upward along normal faults from a reservoir in sedimentary rock situated beneath the unconsolidated valley fill. The fill is predominantly fine-grained glacial outwash that may form an impermeable layer above the sedimentary bedrock, except where vertical permeability is provided by faulting.

\section{$\underline{\text { Sulfate-Flux Measurements }}$}

In order to estimate the total rate of thermal-water discharge in the La Duke area, we collected integrated river samples above and below these areas of discharge on four occasions between 1989 and 1990. The water samples were analyzed for sulfate concentration; differences between upstream and downstream samples are taken to represent the effects of inflow of thermal water with sulfate concentration the same as that in La Duke Hot Spring $(1250 \mathrm{mg} /$ ). The upstream site was located 4.7 $\mathrm{km}$ southeast of La Duke (labeled Queen of the Waters in fig. G-2) and the downstream site was at the Corwin Springs gaging station. Differences in dissolved sulfate between upstream and downstream samples $\left(\Delta \mathrm{SO}_{4}\right)$ are inversely proportional to river discharge $(\mathrm{Q})$ and ranged from 0.75 to $2.12 \mathrm{mg} / \mathrm{L}$ (table $\mathrm{G}-4)$. The value of $\mathrm{Q}$ at the time of each sampling was determined from the stage-discharge relation 


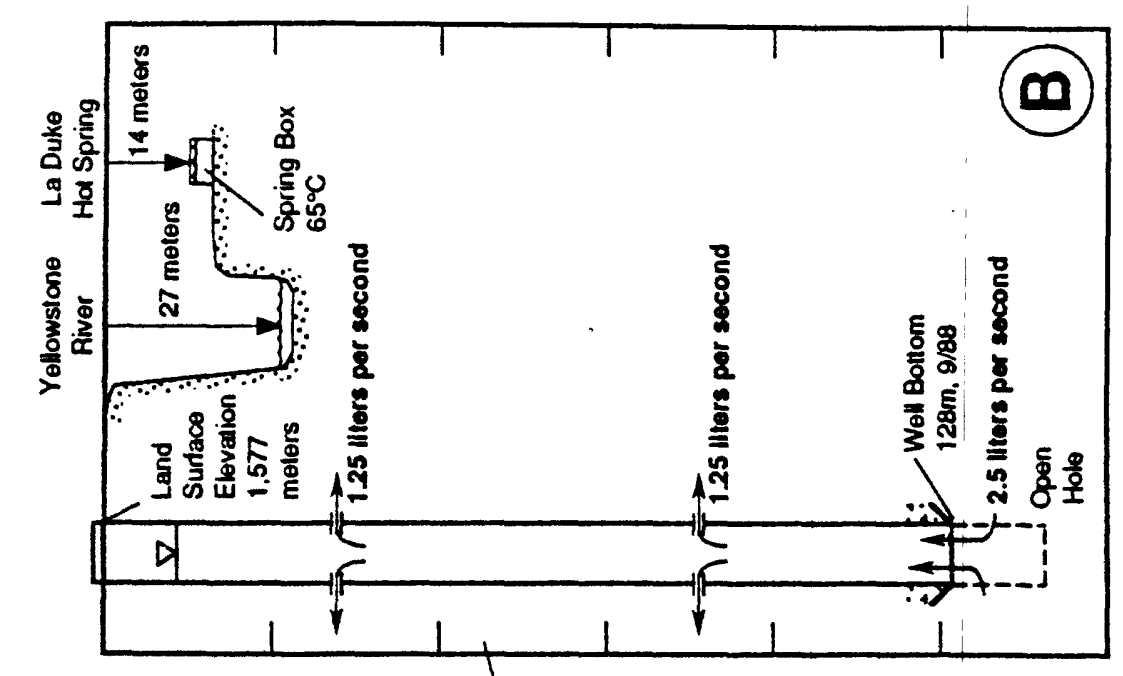

芯氖导

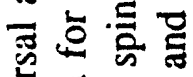

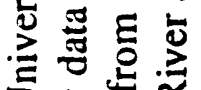

$5 \div$

들

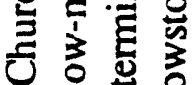

눙 응

可的

实

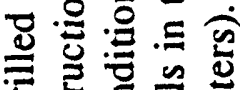

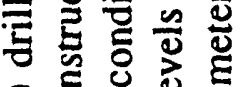

حิ

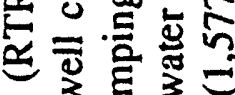

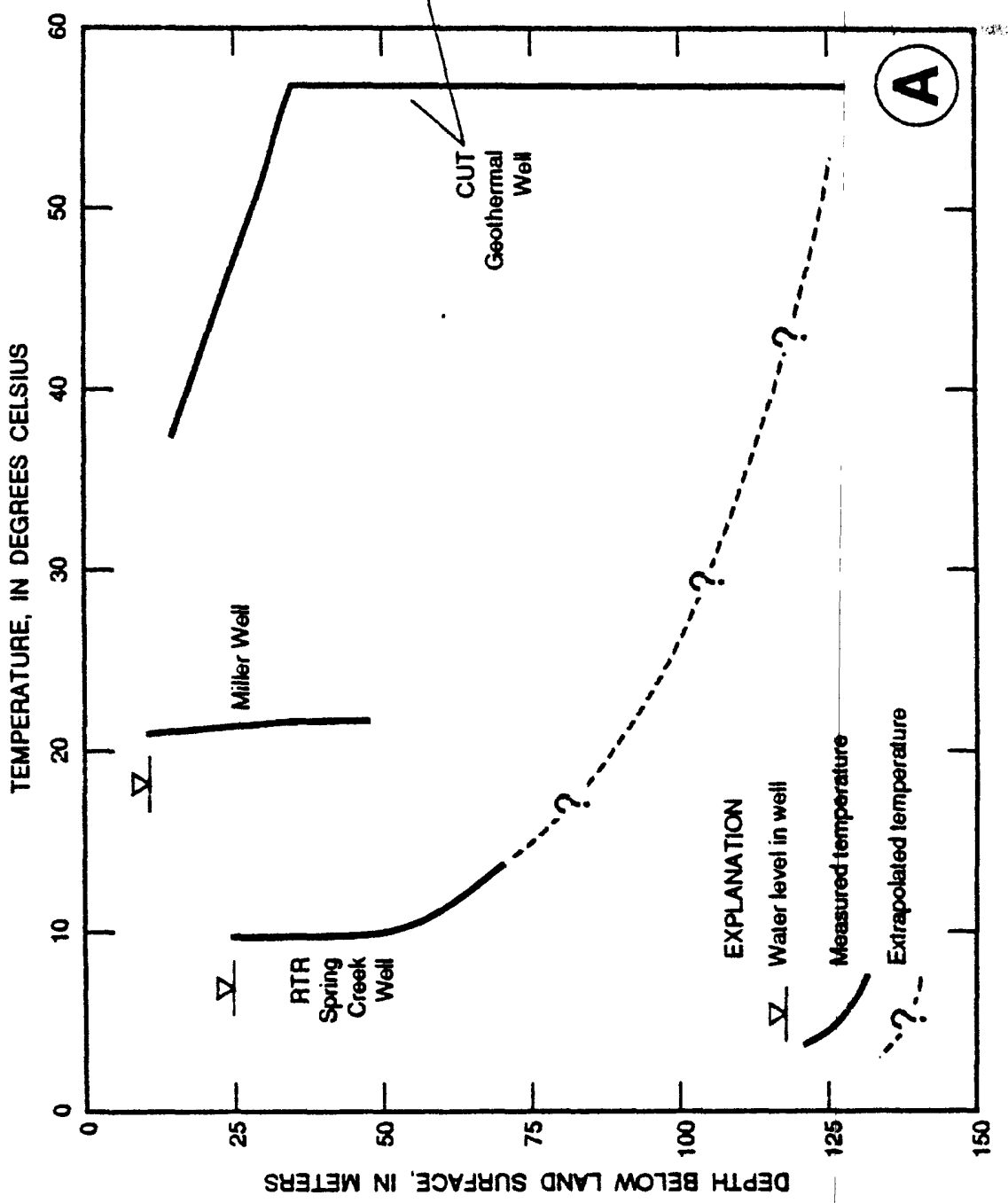

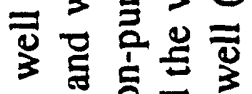

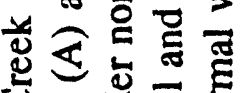

U =

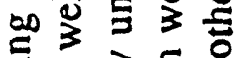

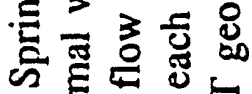

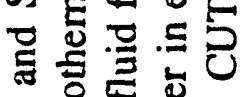

成㟧范

已 巳

을

ज记

3 党

跑 닐

ㅊ. 용

㖣.

吠舟的

등응 웡

和父《

过

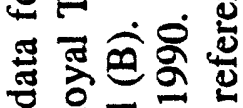

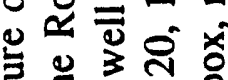

氙记资。

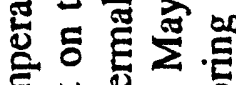

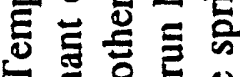

究总品

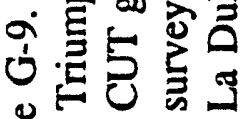

气

i 
at the Corwin Springs gaging station. Total thermal-water inflow $\left(\mathrm{Q}_{\mathrm{TW}}\right)$ is calculated as

$$
\mathrm{Q}_{\mathrm{TW}}=\left(\mathrm{Q} \Delta \mathrm{SO}_{4}\right) / 1250 .
$$

The average value of $\mathrm{Q}_{\mathrm{Tw}}$ is $61 \mathrm{~L} / \mathrm{s}$, with a relative standard deviation of 14 percent. Note that even though the thermal-water inflow represents less than 1 percent of the flow of the river, it can be detected because of its high sulfate content, provided laboratory accuracy of close to \pm 1 percent.

Concentrations of dissolved $\mathrm{Cl}, \mathrm{Ca}$, and $\mathrm{Na}$ were slightly higher at the downstream sampling site than at the upstream sampling site on each of the four sampling dates (except for $\mathrm{Na}$ concentrations for the September 12, 1989 sampling). Smaller increases in these chemicals are consistent with the inference of thermal-water input to the river because they occur at lower concentrations than $\mathrm{SO}_{4}$ in $\mathrm{La}$ Duke thermal water. Differences in concentrations of $\mathrm{Cl}, \mathrm{Ca}$, and $\mathrm{Na}$ between upstream and downstream sites are close to analytical accuracy and should not be used to calculate rates of thermal-water discharge. The distribution of $\mathrm{Q}_{\mathrm{Tw}}$ values calculated from the sulfate data is too limited to determine if the observed variations in thermal-water discharge represent actual changes, for example as a function of river stage, or result from measurement error.

A single measurement of thermal-water discharge in the vicinity of Bear Creek Springs (fig. G-2), using the same technique discussed above, was made on September 28, 1990. The calculated value, based on the increase in dissolved sulfate in integrated samples collected in the Yellowstone River at sites upstream and downstream from a 500 m-long reach over which high-sulfate thermal springs flow into the River was $17 \mathrm{~L} / \mathrm{s}$ (table G-4). This represents a discharge of Bear-Creek-type thermal water with a sulfate concentration of $870 \mathrm{mg} / \mathrm{L}$. Differences in dissolved $\mathrm{Cl}, \mathrm{Ca}$, and $\mathrm{Na}$ lend support to this interpretation. The estimated uncertainty for this thermal-water discharge value is \pm 10 percent, based on estimated errors in streamflow and integrated-sulfate determinations. The total flow of individual hot springs on the banks of the Yellowstone River and Bear Creek on this date was estimated at 5-10 L/s. Streambed-temperature anomalies and areas of warming of river water were detected in the reach over which this inflow of thermal water was calculated (Hamilton and Chambers, this volume). The dissolved sulfate measurements could be repeated to lend support to the interpretations noted here.

An apparent addition of high-sulfate thermal water to the Yellowstone River was also detected in the September 1990 measurements between sites just upstream from the confluence with the Gardner River and $1.4 \mathrm{~km}$ downstream from the confluence. An input of $26 \mathrm{~L} / \mathrm{s}$ of Bear Creek-type thermal water is calculated for this reach, after accounting for the addition of dissolved sulfate from the Gardner River (table G-4). The uncertainty in this calculation could be \pm 80 percent or larger because of errors in the discharge determination for the Gardner River and the significant contribution of sulfate from the Gardner River to the Yellowstone River. No streambed-temperature anomalies have been detected within this reach (Hamilton and Chambers, this volume). Hence, it is likely that there is, in fact, no thermal-water discharge in this area; but additional sulfate-flux measurements are required to confirm this.

Weak streambed-temperature and soil-mercury anomalies, have been detected in the vicinity of the Gardiner airport (Hamilton and Chambers, this volume). No corresponding increase in dissolved sulfate was found in the September 1990 samples collected upstream and downstream 
from this area (table G-4). This suggests that the rate of thermal-water inflow in this area is small and/or that the weak temperature and mercury anomalies do not reflect inflow of high-sulfate thermal water. Water produced from shallow wells near the airport contain $<100 \mathrm{mg} / \mathrm{L}$ sulfate. The anomalous areas near the airport lie along or between the trends of the Landslide Creek and Rainbow Lakes faults, as delineated by electrical geophysical surveys (Stanley and others, this volume), and are also adjacent to the asymmetric, and possibly faulted, axis of the Gardiner syncline (Pierce and others, this volume). These structures could provide conduits for upward ground-water flow in this area.

Two areas further downstream on the Yellowstone River, at the Queen of the Waters site and the confluence with Reese Creek (fig. G-2), exhibit both high soil mercury and streambed thermal anomalies. No river-water samples were collected to isolate these sites from those closer to La Duke. Based on the magnitude of streambed-temperature anomalies in these upstream areas $\left(1^{\circ}\right.$ $6^{\circ} \mathrm{C}$ above river temperature), it is likely that the rate of thermal-water input to the river is small relative to that in the La Duke area, or that nonthermal ground-water inflow is partly or fully responsible for the streambed-temperature anomalies. Low-sulfate $(97 \mathrm{mg} / \mathrm{L})$ water at temperatures near $9^{\circ} \mathrm{C}$ is encountered to depths of $27 \mathrm{~m}$ in the Park Service well adjacent to the Queen of the Waters site (well number 6 in fig. G-2). River temperature during times when streambed temperatures were measured in this area ranged from $1^{\circ}$ to $6^{\circ} \mathrm{C}$.

\section{Well Data}

Data obtained during this study from thermal and nonthermal wells in the Corwin Springs KGRA area are listed in table G-5. Locations of these wells area shown in figure G-2. Of these ten wells, only the CUT geothermal well, the Miller geothermal well, and the U'ren well are considered as tapping thermal water, as evidenced by relatively high sulfate concentrations and $\mathrm{SO}_{4} / \mathrm{Cl}$ ratios and maximum temperatures in excess of $15^{\circ} \mathrm{C}$. The Royal Teton Ranch (RTR) Spring Creek well has a maximum temperature of only $13^{\circ} \mathrm{C}$ at $70 \mathrm{~m}$, but produces water with a $\mathrm{SO}_{4} / \mathrm{Cl}$ ratio close to that for La Duke Hot Spring. This well is only $700 \mathrm{~m}$ northwest of the CUT geothermal well and along the strike of an anomalous streambed-temperature zone (Hamilton and others, this volume), suggesting that it encounters a zone of conductively cooled thermal water.

Temperature profiles obtained during this study (fig. G-9) in the CUT geothermal, Miller, and RTR Spring Creek wells show evidence of disturbance from the effects of vertical fluid flow. Both the CUT and Miller well profiles are affected by fluid flow up the well bore, due in the case of the Miller well to intermittent pumping. In the case of the CUT well, borehole logging data (caliper, televiewer, and spinner logs) collected in May 1990 show that water is flowing upward from the bottom of the casing at a depth of 128 at rates near $2.5 \mathrm{~L} / \mathrm{s}$. About half of this flow leaks out of the well through a break in the casing at $91 \mathrm{~m}$ and half leaks out through a similar break at $37 \mathrm{~m}$. As in the case of well Y-10 at Mammoth Hot Springs, these casing breaks may have resulted from the effects of thermal expansion on casing that was not adequately cemented against the formation. Note that this upflow occurs with no pump in the CUT well and a static water level $11 \mathrm{~m}$ below the top of the casing. Because of the thermal disturbance caused by this upflow, the measured temperature profile in the well does not represent conditions in the adjacent formation, except perhaps near the bottom of the casing where the measured temperature is $57^{\circ} \mathrm{C}$. In fact, it is 
possible that before this well was drilled, the temperature-depth profile at this location more closely resembled that measured in the nearby RTR Spring Creek well to depths of about $70 \mathrm{~m}$. Below 70 $\mathrm{m}$, the undisturbed thermal regime at both sites may have resembled the extrapolated profile shown for the RTR Spring Creek well, reaching temperatures near $57^{\circ} \mathrm{C}$ in sedimentary bedrock at depths below $128 \mathrm{~m}$.

Water-level and elevation measurements indicate that the fluid level in the CUT well is approximately $9 \mathrm{~m}$ above the level of the Yellowstone River, and $2 \mathrm{~m}$ above the level of La Duke Hot Spring (fig. G-9). These differences are indicative of excess head (above hydrostatic) driving thermal water upward in the La Duke area. It is not possible to determine which way thermal water is flowing between La Duke Hot Spring and the CUT well based on water-surface elevations because of the unknown amount of head loss in the upflow conduit supplying La Duke. Cooler fluid temperatures at the bottom of the CUT well $\left(57^{\circ} \mathrm{C}\right)$ compared with temperatures in the hot spring $\left(65^{\circ} \mathrm{C}\right)$ are, however, indicative of lateral flow and conductive cooling from La Duke toward the CUT well. Measurements made of decreases in flow of La Duke Hot Spring during the pumping test on the CUT well in 1986 (Hydrometrics, 1986) demonstrate that sustained production from this well will divert or capture thermal water that currently discharges in La Duke and related river-bank hot springs. The effect of sustained production from the Miller geothermal well on La Duke Hot Spring is unknown but could be expected to be similar that of the CUT geothermal well because of its proximity to thermal springs along the banks of the Yellowstone River and the highsulfate content $(990 \mathrm{mg} / \mathrm{L})$ of water produced from this well .

The average value of reservoir transmissivity calculated from drawdown and recovery data collected during the 1986 aquifer test on the CUT geothermal well was $1.2 \times 10^{-2} \mathrm{~m}^{2} / \mathrm{s}$ (Hydrometrics, 1986). This probably represents a minimum value for the reservoir tapped by this well because the well penetrates only about $11 \mathrm{~m}$ into a permeable zone in bedrock which could be much thicker (Pierce and others, this volume). The actual stratigraphic unit encountered in this well is not known, but is most likely a limestone or sandstone of Paleozoic age. Fine-grained sediments of relatively low permeability overlie the bedrock and are in part responsible for the low value of reservoir storage coefficient $(0.0028)$ calculated by Sonderegger (1987) based on the time required for the effects of drawdown from this well to reach La Duke Hot Spring (84 minutes). The combination of relatively high transmissivity and low storage coefficient would result in relatively rapid transmission of reservoir drawdown induced by production from this well to distant locations, as discussed in the next section of the report, "Effects of Potential Geothermal Development".

The $62 \mathrm{~m}$-deep U'ren well is located $1.25 \mathrm{~km}$ south of La Duke Hot Spring on the east side of Highway 89. A thermal component in water tapped by this well is indicated by the relatively high temperature of fluid produced from the well during post-drilling airlift operations $\left(27^{\circ} \mathrm{C}\right)$, compared with temperatures in other wells of comparable depth along the Gardiner fault. A single fluid sample for chemical analysis was obtained by Park Service personnel in 1987 using a bailer. Although dissolved constituents in this sample, for example $259 \mathrm{mg} / \mathrm{L}$ sulfate, were significantly less concentrated than in La Duke Hot Spring water, the $\mathrm{SO}_{4} / \mathrm{Cl}$ ratio is similar. The driller's log for the U'ren well indicates limestone between 31 and $62 \mathrm{~m}$. It is possible that sustained production from this well could also divert thermal water from the hot springs in the La Duke area.

Four wells located within the eastern part of the Corwin Springs KGRA near the town of 
Gardiner were inventoried during this study (table G-5). No evidence of elevated fluid temperatures was found to suggest a thermal component in any of these wells (temperatures $\leq 12^{\circ} \mathrm{C}$ ). Fluid chemistries from samples pumped from these wells are quite variable, with sulfate concentrations ranging from 25 (McPherson well) to 1,522 (Hoppe well). These differences apparently reflect differences in rock types encountered at each site. Travertine outcrops near each well suggest that they are close to sites where hot-spring discharge occurred in the past (Pierce and others, this volume), and may still be underlain by hot-water reservoirs.

\section{Clearwater Springs}

Clearwater Springs is a group of hot springs located on the west and east banks of Obsidian Creek $0.8 \mathrm{~km}$ north of Roaring Mountain (fig. B-1). Spring temperatures range from $70-95^{\circ} \mathrm{C}$, and the combined discharge from the springs is about $10 \mathrm{~L} / \mathrm{s}$. . Thermal waters discharge from two separate areas of spring vents, separated by a distance of about $150 \mathrm{~m}$. Thermal waters in the northernmost area (CW-3B and CW-3C) are more concentrated and higher in $\mathrm{pH}$ than thermal waters in the southernmost area (CW-2 and CW-1) (Kharaka and others, this volume). Most of the discharge occurs in the northernmost area where $\mathrm{Cl}$ concentrations of $435-480 \mathrm{mg} / \mathrm{L}$ have been measured over the course of this study. Clearwater Springs is considered in this study to be representative of the high-chloride, low sulfate end-member derived from caldera-related volcanic rocks. The total discharge of thermal water at Clearwater over the 1988-1990 period was monitored for comparison with similar data from the Mammoth area.

Thermal-water discharge at Clearwater was calculated from the difference in chloride flux in Obsidian Creek at sites above and below the hot springs, assuming a $\mathrm{Cl}$ concentration in thermal water of $470 \mathrm{mg} / \mathrm{L}$. These data (table G-6) show a range in calculated thermal-water discharge of 2.6 to $10.6 \mathrm{~L} / \mathrm{s}$, with an RSD of 38 percent of the mean value of $6.5 \mathrm{~L} / \mathrm{s}$. Hot-spring flow at Clearwater may be more variable than at Hot River and La Duke, although errors in streamflow and chloride determinations cause more scatter in the Clearwater data set compared with these other areas. This results from the fact that Obsidian Creek at the gaging site upstream from the hot springs contains high chloride concentrations contributed by other areas of hot-spring inflow further upstream, making it difficult to accurately detect the increase in chloride from the Clearwater springs. No pattern of seasonal or annual variations in thermal-water discharge can be delineated in the available data.

\section{Other Monitoring Sites}

Water samples were collected periodically at two other sites in the study area where discharge measurements were not feasible to provide baseline data on variations in water chemistry. At Bear Creek Springs, three areas of hot-spring discharge were identified (BC-1, BC-2, and BC-3 in fig. G-10). Travertine-depositing springs $\mathrm{BC}-1$ and $\mathrm{BC}-2$ produce thermal water of a $\mathrm{Ca}-\mathrm{Na}-\mathrm{HCO}_{3}-\mathrm{SO}_{4}$ type with a combined discharge estimated at $5-10 \mathrm{~L} / \mathrm{s}$ (Kharaka and others, this volume). Spring $\mathrm{BC}-3$ is a lower-temperature, $\mathrm{Na}-\mathrm{HCO}_{3}$-type fluid source with discharge estimated at $<1 \mathrm{~L} / \mathrm{s}$. The chloride concentration in each of these springs is similar $(42-43 \mathrm{mg} / \mathrm{L})$. Partial chemical analyses 

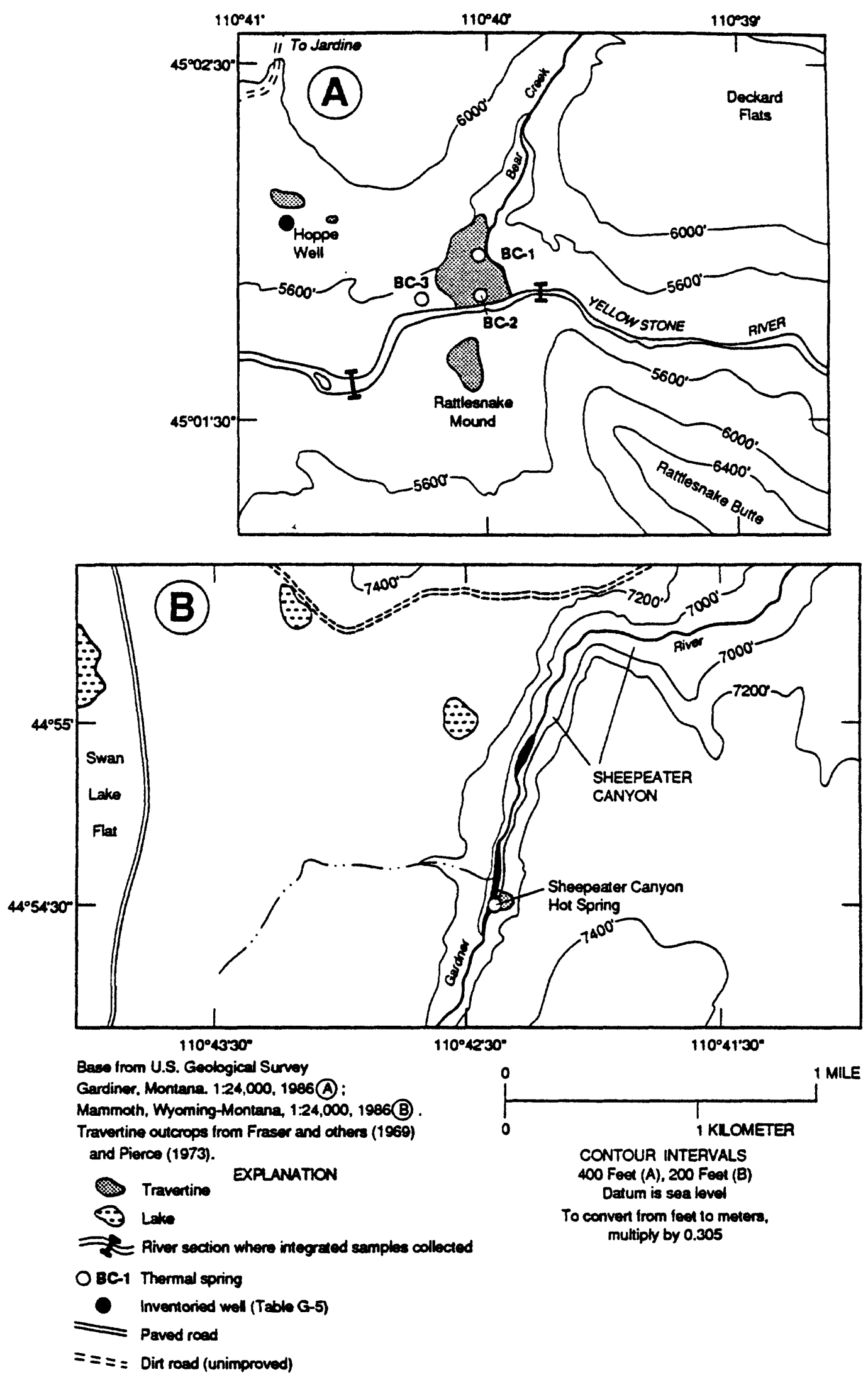

Figure G-10. Area around Bear Creek Springs in the Corwin Springs Known Geothermal Resources Area (A) and area around Sheepeater Canyon Hot Spring in Yellowstone National Park (B) showing locations of springs sampled during this study and topographic contours. 
on 16 water samples from $\mathrm{BC}-1$ show relative standard deviations of 6.7 percent $(\mathrm{Cl})$ and 12.3 percent $\left(\mathrm{SO}_{4}\right)$ about the mean values (table G-7). No consistent pattern of seasonal variation exists and most of the variability can probably be attributed to analytical accuracy.

Travertine-depositing springs and seeps occur along the east bank of the Gardner River in the Sheepeater Canyon area south of Bunsen Peak (fig. G-10). The highest discharge spring occurs at the base of a travertine ledge near river level; its flow is estimated at $2 \mathrm{~L} / \mathrm{s}$. The combined discharge of all springs above river level was not measured but is estimated at $4 \mathrm{~L} / \mathrm{s}$. Additional thermal-water discharge occurs through the river bed. Travertine older than similar deposits at river level occurs at higher elevations in the canyon and east of the canyon (Pierce and others, this volume), indicating a lowering of points of hot-spring discharge as the river has eroded the canyon. Variability in $\mathrm{Cl}$ and $\mathrm{SO}_{4}$ in the spring sampled at the base of the travertine ledge is of similar magnitude to that for Bear Creek spring BC-1 (table G-7).

\section{Summary}

The following items summarize the data and discussions presented in this section of the report.

1. Hydrologic data available within the study area are limited to the discharge characteristics of springs and their variations with time, and data from 3 thermal and 7 nonthermal wells of depths less than $150 \mathrm{~m}$.

2. These data allow us to calculate rates of thermal-water discharge from various areas inside and outside the Park, chemical characteristics of thermal waters in each area, and differences in hydraulic head within and between areas.

3. For the period 1987-1990, total thermal-water discharge in the Mammoth-Hot River area averaged $560 \mathrm{~L} / \mathrm{s}$, of which $43 \mathrm{~L} / \mathrm{s}$ discharged in the Mammoth Outflow stream which drains springs on the south side of the Main Terrace. The total hot-spring discharge on the Mammoth Terraces was estimated at $63 \mathrm{~L} / \mathrm{s}$ during our study, in general agreement with measurements made during the $1928-1932$ period.

4. An additional flow of about $30 \mathrm{~L} / \mathrm{s}$ of Mammoth-type thermal water discharges into the Gardner River from springs and seeps located between the 45th parallel bridge and the confluence with the Yellowstone River. Tracer tests establish that there is a hydraulic connection between one of these discharge areas, at Chinese Garden, and a sinkhole at Mammoth Terraces.

5. Variations in thermal-water discharge in Hot River over the 1986-90 period were of comparable magnitude to those expected from measurement errors. The distribution of calculated thermalwater discharge values, however, shows an inverse correlation with precipitation in the Mammoth area, indicating that there might be small changes in the outflow from the Mammoth hydrothermal system in response to naturally occurring hydrologic processes.

6. Periodic streamflow measurements and chemical sampling, and the continuous record of temperature, stage, and specific conductance obtained at Hot River indicate changes in each 
property related to changes in the input of nonthermal water from the Gardner River, Clematis Creek, and Primrose Creek through sinkholes.

7. The flow of La Duke Hot Spring in the Corwin Springs KGRA averaged $6.9 \pm 1.0 \mathrm{~L} / \mathrm{s}$ during this study. Total thermal-water discharge from springs and seeps that discharge into the Yellowstone River in the La Duke area averaged $61 \pm 8.5 \mathrm{~L} / \mathrm{s}$ for four sets of measurements of chemical flux in the river. The nearby CUT geothermal well is capable of producing $25 \mathrm{~L} / \mathrm{s}$.

8. Measurements of chemical flux in the Yellowstone River above and below Bear Creek Springs on September 28, 1990, yielded a total thermal-water discharge value of $17 \mathrm{~L} / \mathrm{s}$. Additional chemical-flux measurements on the Yellowstone River at sites farther downstream do not provide any clear indications of other areas of thermal-water inflow, except in the vicinity of La Duke Hot Spring.

9. There is a hydraulic connection between the CUT geothermal well and La Duke Hot Spring. The measured temperature profile in the CUT well has been substantially disturbed by fluid flow up the well casing under unpumped conditions.

10. Hydrologic monitoring at Clearwater Springs indicates that hot-spring discharge is more variable than at the other thermal areas monitored in this study, but measurement conditions result in relatively large errors in calculated thermal-water discharge.

\section{Acknowledgments}

We thank Christopher D. Farrar and Andrew R. Skerda for valuable assistance in hydrologic data collection activities. Borehole measurements in well Y-10 and CUT geothermal well were made by Frederick L. Paillet and Richard E. Hodges. Irving Friedman and Daniel R. Norton shared their data on chloride-flux monitoring at several sites in the study area and contributed valuable interpretive discussions. Access to privately owned wells and information about these wells was provided by numerous land owners in the Corwin Springs KGRA, including the Church Universal and Triumphant. Valuable information about hydrologic conditions in the La Duke area was also provided by Hydrometrics Consulting Scientists and Engineers (Helena, Montana), Doris Whithorn (Livingston, Montana), and William Kupfer (Joliet, Montana).

\section{$\underline{\text { References Cited }}$}

Allen, E.T. and Day, A.L., 1935, Hot Springs of the Yellowstone National Park: Carnegie Institution of Washington Publication 466, 525 p.

Dole, R.B., 1914, Sanitary inspections 1914: in U.S. Department of Agriculture Bulletin No. 57, $92 \mathrm{p}$.

Bargar, K.E., 1978, Geology and thermal history of Mammoth Hot Springs, Yellowstone National Park, Wyoming: U.S. Geological Survey Bulletin 1444, 55 p. 
Farrar, C.D., Sorey, M.L., Rojstaczer, S.A., Janik, C.J., Mariner, R.H., and Winnett, T.L., 1985, Hydrologic and geochemical monitoring in Long Valley caldera, Mono County, California, 1982-1984: U.S. Geological Survey Water-Resources Investigations Report 85-4183, 139 p.

Fraser, G.D., Waldrop, H.A., and Hyden, H.J., 1969, Geology of the Gardiner area, Park County, Montana: U.S. Geological Survey Bulletin 1,277, 118 p.

Friedman, I. and Norton, D.R., 1990, Anomalous chloride discharges from Yellowstone National Park: Journal of Volcanology and Geothermal Research, v. 42, p. 225-234.

Hydrometrics, 1986, Aquifer testing and evaluation of a geothermal well at Royal Teton Ranch near Corwin Springs, Montana: Report prepared for Edward L. Francis, Royal Teton Ranch by Hydrometrics, 2727 Airport Road, Helena, Montana 59021, 37 p.

Hydrometrics, 1987, Water production tests of La Duke Hot Spring, Park County, Montana: Report prepared for Royal Teton Ranch by Hydrometrics, 2727 Airport Road, Helena, Montana $59021,12 \mathrm{p}$.

Janecky, D.R., Spall, W.D., Dixon, P.R., and Bayhurst, G.K., 1991, A multicomponent tracer experiment in Mammoth Hot Springs system, Yellowstone National Park: in Isotope and Nuclear Chemistry Division Annual Report FY 1990, October 1989-September 1990, Los Alamos National Laboratory report, (in press).

Leonard, R.B., Tordis, M.B., and Midtlyng, N.A., 1978, Selected data from thermal-spring areas, southwestern Montana: U.S. Geological Survey Open-File Report 78-438, 71 p.

Mariner, R.H., Presser, T.S., and Evans, W.C., 1976, Chemical characteristics of the major thermal springs of Montana: U.S. Geological Survey Open-File Report 76-480, 31 p.

Norton, D.R., Friedman, I., Mohrman, J., and Hutchinson, R.A., 1989, Monitoring of thermal activity in the northern part of Yellowstone National Park: Part 1 -February 1985-June 1988: U.S. Geological Survey Open-File Report 89-211, 35 p.

Pierce, K.L., 1973, Surficial geologic map of Mammoth Quadrangle and part of the Gardiner Quadrangle, Yellowstone National Park, Wyoming and Montana: U.S. Geological Survey Miscellaneous Geologic Investigations Map I-641.

Sonderegger, J.L., 1987, Potential effects of production from a geothermal well located near La Duke Hot Spring: Montana Bureau of Mines report to Montana State Department of Health and Environmental Sciences and Department of Natural Resources and Conservation, $12 \mathrm{p}$.

Thompson, J.M., Presser, T.S., Barnes, R.B., and Bird, D.B., 1975, Chemical analyses of the waters of Yellowstone National Park, Wyoming, from 1965-1973: U.S. Geological Survey Open-File Report 75-25, 59 p.

White, D.E., Fournier, R.O., Muffler, L.J.P., and Truesdell, A.H., 1975, Physical results of research drilling in thermal areas in Yellowstone National Park, Wyoming: U.S. Geological Survey Professional Paper 892, $70 \mathrm{p}$. 
Table G-1. Hydrologic monitoring data for Mammoth Outflow (site Mammoth Springs Outflow at Mammoth) in Yellowstone National Park

Sample Date: Listed by year, month, and day.

Gage Height: Reported in feet; multiply by 0.305 to obtain meters.

Discharge: Calculated from gage height at weir below Lost Lake after September 13, 1988; measured at site above Lost Lake on and before that date.

Laboratory: NORT, data supplied by Dan Norton, U.S. Geological Survey, Denver, Colorado, based on corrected values from analyses by U.S. Geological Survey Central Laboratory, Arvada, Colorado; CL, U.S. Geological Survey Central Laboratory, Arvada, Colorado; ING, U.S. Geological Survey laboratory, Menlo Park, California , under the direction of W.C. Evans.

Chloride Flux: Discharge times chloride concentration.

Thermal Discharge: Chloride flux divided by $170 \mathrm{mg} / \mathrm{L}$.

[L/s, liters per second; $\mu \mathrm{S} / \mathrm{cm}$, microsiemens per centimeter, $\mathrm{g} / \mathrm{s}$, grams per second; * , no data]

\begin{tabular}{|c|c|c|c|c|c|c|c|c|c|}
\hline $\begin{array}{l}\text { Sample } \\
\text { Date }\end{array}$ & $\begin{array}{l}\text { Sample } \\
\text { Time } \\
\text { (hour) }\end{array}$ & $\begin{array}{c}\text { Water } \\
\text { Temperature } \\
\text { (Celsius) }\end{array}$ & $\begin{array}{l}\text { Gage } \\
\text { Height } \\
\text { (feet) }\end{array}$ & $\begin{array}{l}\text { Dis- } \\
\text { charge } \\
(\mathrm{L} / \mathrm{s})\end{array}$ & $\begin{array}{c}\text { Chloride } \\
\text { (mg/L) }\end{array}$ & $\begin{array}{l}\text { Conduct- } \\
\text { ance } \\
(\mu \mathrm{S} / \mathrm{cm})\end{array}$ & $\begin{array}{l}\text { Labo- } \\
\text { ratory }\end{array}$ & $\begin{array}{c}\text { Chloride } \\
\text { Flux } \\
\text { (g/s) }\end{array}$ & $\begin{array}{c}\text { Thermal } \\
\text { Discharge } \\
(\mathrm{L} / \mathrm{s})\end{array}$ \\
\hline 860904 & * & * & * & 79.3 & 172 & * & NORT & 13.6 & 80.0 \\
\hline 870115 & * & * & $\star$ & 104.7 & 171 & $\star$ & NORT & 17.9 & 105.3 \\
\hline 870130 & $\star$ & * & $\star$ & * & 171 & $\star$ & NORT & $\star$ & $\star$ \\
\hline 870204 & $\star$ & * & * & * & 169 & $\star$ & NORT & * & * \\
\hline 870212 & * & * & * & * & 172 & * & NORT & * & * \\
\hline 870220 & * & * & * & * & 168 & * & NORT & $\star$ & $\star$ \\
\hline 870226 & $\star$ & * & $\star$ & 92.0 & 170 & $\star$ & NORT & 15.6 & 91.8 \\
\hline 870306 & * & * & * & * & 169 & * & NORT & * & * \\
\hline 870313 & * & $\star$ & * & * & 172 & $\star$ & NORT & * & $\star$ \\
\hline 870320 & * & $\star$ & * & * & 177 & * & NORT & * & $\star$ \\
\hline 870401 & $\star$ & * & * & * & 172 & * & NORT & $\star$ & $\star$ \\
\hline 870410 & * & $\star$ & * & * & 171 & • & NORT & $\star$ & $\star$ \\
\hline 870417 & $\star$ & * & * & * & 174 & $\star$ & NORT & * & $\star$ \\
\hline 870421 & $\star$ & * & $\star$ & $\star$ & 169 & $\star$ & NORI & * & $\star$ \\
\hline 870501 & $\star$ & * & * & * & 172 & * & NORT & * & $\star$ \\
\hline 870512 & * & * & $\star$ & $\star$ & 177 & * & NORT & $\star$ & $\star$ \\
\hline 870521 & $\star$ & * & * & * & 173 & $\star$ & NORT & * & * \\
\hline 870530 & * & * & * & $\star$ & 170 & * & NORT & * & * \\
\hline 870605 & * & * & $\star$ & * & 169 & $\star$ & NORT & $\star$ & $\star$ \\
\hline 870610 & $\star$ & * & * & * & 170 & * & NORT & * & * \\
\hline 870619 & * & * & $\star$ & * & 171 & $\star$ & NORT & * & $\star$ \\
\hline 870625 & $\star$ & $\star$ & * & 85.0 & 173 & $\star$ & NORT & 14.7 & 86.5 \\
\hline 870703 & $\star$ & * & * & * & 172 & $\star$ & NORT & $\star$ & * \\
\hline 870709 & $\star$ & * & * & * & 173 & * & NORT & $\star$ & $\star$ \\
\hline 870715 & $\star$ & $\star$ & $\star$ & * & 172 & $\star$ & NORI & * & * \\
\hline 870724 & $\star$ & * & $\star$ & * & 170 & $\star$ & NORT & * & $\star$ \\
\hline 870730 & $\star$ & * & * & * & 173 & * & NORT & * & $\star$ \\
\hline 870804 & $\star$ & * & $\star$ & * & 173 & * & NORT & * & * \\
\hline 870812 & * & * & * & * & 170 & * & NORT & * & $\star$ \\
\hline 870821 & $\star$ & * & * & $\star$ & 171 & * & NORT & * & * \\
\hline 870827 & $\star$ & * & * & 39.6 & 170 & * & NORT & 6.7 & 39.4 \\
\hline 870903 & * & * & * & 56.6 & 170 & * & NORT & 9.6 & 56.5 \\
\hline 870912 & $\star$ & $\star$ & $\star$ & * & 171 & * & NORT & * & * \\
\hline
\end{tabular}




$\begin{array}{cccccccccc}\begin{array}{c}\text { Sample } \\ \text { Date }\end{array} & \begin{array}{c}\text { Sample } \\ \text { Time }\end{array} & \begin{array}{c}\text { Water } \\ \text { Temperature }\end{array} & \begin{array}{c}\text { Gage } \\ \text { Height }\end{array} & \begin{array}{c}\text { Dis- } \\ \text { charge }\end{array} & \begin{array}{c}\text { Chloride } \\ (\mathrm{mg} / \mathrm{L})\end{array} & \begin{array}{c}\text { Conduct- } \\ \text { ance }\end{array} & \begin{array}{c}\text { Labo- } \\ \text { ratory }\end{array} & \begin{array}{c}\text { Chloride } \\ \text { Flux }\end{array} & \begin{array}{c}\text { Thermal } \\ \text { Discharge }\end{array} \\ & \text { (hour) } & \text { (Celsius) } & (\text { feet }) & (\mathrm{L} / \mathrm{s}) & & (\mu \mathrm{S} / \mathrm{cm}) & & (\mathrm{g} / \mathrm{s}) & (\mathrm{L} / \mathrm{s})\end{array}$

\begin{tabular}{|c|c|c|c|c|c|c|c|c|c|}
\hline 870919 & * & * & * & * & 171 & * & NORT & * & * \\
\hline 871009 & * & * & * & * & 172 & $\star$ & NORT & $\star$ & * \\
\hline 871023 & * & * & * & * & 172 & * & NORT & * & * \\
\hline 871106 & * & * & $\star$ & * & 171 & * & NORT & $\star$ & * \\
\hline 871204 & * & * & * & 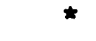 & 172 & * & NORT & $\star$ & $\star$ \\
\hline 880106 & * & * & $\star$ & * & 271 & * & NORT & $\star$ & $\star$ \\
\hline 880205 & $\star$ & * & * & $\star$ & 179 & * & NORT & $\star$ & $\star$ \\
\hline 880212 & * & * & * & * & 170 & * & NORT & $\star$ & * \\
\hline 880226 & * & * & * & * & 170 & * & NORT & $\star$ & * \\
\hline 880318 & * & * & $\star$ & * & 164 & $\star$ & NORT & * & $\star$ \\
\hline 880401 & * & * & * & * & 167 & * & NORT & * & $\star$ \\
\hline 880415 & $\star$ & $\star$ & $\star$ & $\star$ & 166 & * & NORT & $\star$ & * \\
\hline 880429 & * & * & * & * & 164 & * & NORT & $\star$ & * \\
\hline 880513 & $\star$ & * & * & $\star$ & 165 & * & NORT & $\star$ & $\star$ \\
\hline 880519 & * & * & * & $\star$ & 166 & * & NORT & * & * \\
\hline 880527 & $\star$ & * & $\star$ & $\star$ & 167 & * & NORT & * & * \\
\hline 880603 & * & * & $\star$ & $\star$ & 166 & $\star$ & NORT & * & * \\
\hline 880610 & $\star$ & * & $\star$ & $\star$ & 168 & * & NORT & * & * \\
\hline 880617 & $\star$ & $\star$ & $\star$ & * & 168 & * & NORT & * & $\star$ \\
\hline 880624 & * & $\star$ & * & $\star$ & 168 & * & NORT & * & $\star$ \\
\hline 880805 & 940 & 15.0 & * & 19.8 & * & * & * & * & * \\
\hline 880811 & 1415 & 22.5 & * & 25.5 & $\star$ & * & * & * & $\star$ \\
\hline 880818 & 1200 & 20.0 & $\star$ & 19.8 & $\star$ & $\star$ & $\star$ & * & * \\
\hline 880825 & 1430 & 22.0 & $\star$ & * & * & * & $\star$ & * & * \\
\hline 880901 & 1055 & 15.0 & $\star$ & 22.7 & $\star$ & $\star$ & $\star$ & $\star$ & * \\
\hline 880908 & 1022 & * & * & 22.7 & * & $\star$ & $\star$ & * & * \\
\hline 880913 & 1530 & $\star$ & $\star$ & 25.5 & * & * & * & * & * \\
\hline 880914 & 745 & 12.0 & 0.25 & 23.8 & 170 & 2050 & CI & 4.0 & 23.5 \\
\hline 880915 & 1715 & 19.0 & * & $\star$ & * & $\star$ & $\star$ & $\star$ & * \\
\hline 880922 & 1400 & 22.0 & $\star$ & * & $\star$ & * & * & * & * \\
\hline 880929 & 1330 & 18.0 & * & * & * & ; $\quad$ & * & * & * \\
\hline 881006 & 730 & 8.0 & 0.26 & 25.2 & 160 & 1980 & CI & 4.0 & 23.5 \\
\hline 881006 & 1545 & 17.0 & * & * & 160 & $\star$ & NORT & * & * \\
\hline 881013 & 1145 & * & 0.28 & 28.3 & 170 & * & NORT & 4.8 & 28.2 \\
\hline 881020 & 1715 & 15.0 & 0.27 & 26.7 & 170 & $\star$ & NORT & 4.5 & 26.5 \\
\hline 881027 & 1450 & 13.0 & 0.28 & 28.3 & 170 & $\star$ & NORT & 4.8 & 28.2 \\
\hline 881102 & 1545 & 12.5 & 0.28 & 28.3 & 170 & 2000 & CI & 4.8 & 28.2 \\
\hline 881118 & 1540 & 11.0 & 0.30 & 31.4 & 170 & * & NORT & 5.3 & 31.2 \\
\hline 881206 & 1700 & 9.0 & 0.30 & 31.4 & 170 & 2150 & CI & 5.3 & 31.2 \\
\hline 881216 & 1437 & 7.5 & 0.30 & 31.4 & 170 & 1 * & NORT & 5.3 & 31.2 \\
\hline 890110 & 845 & 6.0 & 0.27 & 26.9 & 170 & 2090 & CI & 4.6 & 27.1 \\
\hline 890214 & * & $\star$ & * & * & 170 & * & NORT & * & * \\
\hline 890306 & 1420 & 10.0 & 0.25 & 23.8 & 170 & $\star$ & NORT & 4.0 & 23.5 \\
\hline 890315 & 1100 & 9.5 & 0.26 & 25.2 & 170 & 2100 & CI & 4.3 & 25.3 \\
\hline 890330 & 1550 & 15.0 & 0.26 & 25.2 & 170 & * & NORT & 4.3 & 25.3 \\
\hline 890411 & 1030 & 11.0 & 0.26 & 25.2 & 170 & 2110 & CI & 4.3 & 25.3 \\
\hline 890427 & 1115 & 15.0 & 0.32 & 34.6 & * & * & * & * & * \\
\hline 890510 & 1545 & 18.0 & 0.34 & 37.9 & 170 & 2070 & CL & 6.4 & 37.6 \\
\hline 890524 & 1030 & 13.0 & 0.40 & 48.1 & * & * & * & * & * \\
\hline 890607 & 1150 & 23.5 & 0.35 & 39.4 & 180 & 2050 & CI & 7.1 & 41.8 \\
\hline 890615 & 1220 & 20.0 & 0.36 & 41.3 & * & * & $\star$ & * & * \\
\hline 890622 & 1521 & 23.5 & 0.37 & 43.0 & * & $\star$ & $\star$ & $\star$ & * \\
\hline 890626 & 1055 & 19.0 & 0.38 & 44.7 & * & $\star$ & $\star$ & * & * \\
\hline 890630 & 905 & 17.5 & 0.36 & 41.3 & * & $\star$ & $\star$ & * & $*$ \\
\hline
\end{tabular}




\begin{tabular}{|c|c|c|c|c|c|c|c|c|c|}
\hline $\begin{array}{l}\text { Sample } \\
\text { Date }\end{array}$ & $\begin{array}{l}\text { Sample } \\
\text { Time } \\
\text { (hour) }\end{array}$ & $\begin{array}{c}\text { Water } \\
\text { Temperature } \\
\text { (Celsius) }\end{array}$ & $\begin{array}{l}\text { Gage } \\
\text { Height } \\
\text { (feet) }\end{array}$ & $\begin{array}{c}\text { Dis- } \\
\text { charge } \\
(\mathrm{L} / \mathrm{s})\end{array}$ & $\begin{array}{l}\text { Chloride } \\
(\mathrm{mg} / \mathrm{L})\end{array}$ & $\begin{array}{l}\text { Conduct- } \\
\text { ance } \\
(\mu \mathrm{S} / \mathrm{cm})\end{array}$ & $\begin{array}{l}\text { Labo- } \\
\text { ratory }\end{array}$ & $\begin{array}{l}\text { Chloride } \\
\text { Flux } \\
\text { (g/s) }\end{array}$ & $\begin{array}{c}\text { Thermal } \\
\text { Discharge } \\
(\mathrm{L} / \mathrm{s})\end{array}$ \\
\hline 890705 & 1130 & 24.0 & 0.34 & 37.9 & 180 & 2050 & CI & 6.8 & 40.0 \\
\hline 890714 & 930 & 19.0 & 0.36 & 41.3 & * & * & $\star$ & $\star$ & * \\
\hline 890720 & 1430 & 28.0 & 0.32 & 34.6 & $\star$ & $\star$ & $\star$ & $\star$ & $\star$ \\
\hline 890728 & 1400 & 28.0 & 0.31 & 32.9 & $\star$ & $\star$ & $\star$ & $\star$ & * \\
\hline 890803 & 900 & 17.0 & 0.34 & 37.9 & $\star$ & $\star$ & $\star$ & $\star$ & $\star$ \\
\hline 890808 & 800 & 18.0 & 0.32 & 36.3 & 180 & 2080 & $C I$ & 6.5 & 38.2 \\
\hline 890817 & 1110 & 19.0 & 0.33 & 36.3 & * & * & $\star$ & $\star$ & $\star$ \\
\hline 890823 & 1415 & 25.0 & 0.32 & 34.6 & $\star$ & $\star$ & $\star$ & $\star$ & $\star$ \\
\hline 890831 & 1250 & 19.0 & 0.36 & 41.3 & ^ & $\star$ & ^ & $\star$ & * \\
\hline 890908 & 1310 & $\star$ & 0.40 & 48.1 & 175 & $\star$ & $\mathbf{Y K}$ & 8.4 & 49.4 \\
\hline 890911 & 1245 & 16.0 & 0.39 & 46.4 & 180 & 1970 & CI & 8.4 & 49.4 \\
\hline 890915 & 1205 & 18.0 & 0.40 & 48.1 & * & * & * & * & * \\
\hline 890922 & 1205 & 11.0 & 0.40 & 48.1 & * & * & $\star$ & $\star$ & $\star$ \\
\hline 890928 & 1600 & 22.0 & 0.38 & 44.7 & $\star$ & $\star$ & * & * & * \\
\hline 890928 & 1600 & 22.0 & 0.38 & 44.7 & 170 & $\star$ & $\mathrm{YK}$ & 7.6 & 44.7 \\
\hline 891003 & 1045 & 11.0 & 0.41 & 50.1 & 170 & 2030 & CL & 8.5 & 50.0 \\
\hline 891018 & 830 & 12.0 & 0.55 & 77.9 & $\star$ & $\star$ & * & * & $\star$ \\
\hline 891103 & 1400 & 11.0 & 0.40 & 48.1 & $\star$ & $\star$ & * & $\star$ & $\star$ \\
\hline 891115 & 1010 & 8.0 & 0.39 & 46.4 & 170 & 2040 & CL & 7.9 & 46.5 \\
\hline 891213 & 1545 & 10.0 & 0.41 & 50.1 & $\star$ & * & $\star$ & $\star$ & * \\
\hline 900103 & 1230 & 6.9 & 0.40 & 48.1 & 170 & 2152 & CL & 8.2 & 48.2 \\
\hline 900117 & 1430 & 10.5 & 0.38 & 44.7 & $\star$ & $\star$ & $\star$ & $\star$ & $\star$ \\
\hline 900130 & 1455 & 8.0 & 0.40 & 48.1 & $\star$ & * & • & * & * \\
\hline 900216 & 845 & 4.0 & 0.39 & 46.4 & 160 & 2040 & CI & 7.4 & 43.5 \\
\hline 900219 & 1535 & 10.0 & 0.38 & 44.7 & $\star$ & $\star$ & $\star$ & $\star$ & $\star$ \\
\hline 900307 & $\star$ & 12.0 & 0.39 & 46.4 & $\star$ & $\star$ & $\star$ & $\star$ & $\star$ \\
\hline 900327 & 1340 & * & 0.40 & 48.1 & $\star$ & $\star$ & * & * & * \\
\hline 900404 & 1030 & 12.0 & 0.41 & 50.1 & 370 & 2020 & CI & 8.5 & 50.0 \\
\hline 900413 & 1035 & 16.0 & 0.41 & 50.1 & $\star$ & $\star$ & * & $\star$ & $\star$ \\
\hline 900418 & 900 & 12.0 & 0.40 & 48.1 & $\star$ & $\star$ & $\star$ & * & $\star$ \\
\hline 900425 & 1449 & 22.0 & 0.38 & 14.7 & * & * & $\star$ & * & * \\
\hline 900507 & 1220 & $\star$ & 0.39 & 46.4 & * & * & $\star$ & * & * \\
\hline 900509 & 1415 & 19.0 & 0.39 & 46.4 & 160 & 2020 & CI & 7.4 & 43.5 \\
\hline 900517 & 1210 & 19.0 & 0.39 & 46.4 & $\star$ & 1980 & CL & $\star$ & $\star$ \\
\hline 900522 & 1125 & $\star$ & 0.38 & 44.7 & $\star$ & $\star$ & $\star$ & $\star$ & $\star$ \\
\hline 900529 & 945 & 17.0 & 0.39 & 46.4 & $\star$ & * & $\star$ & * & $\star$ \\
\hline 900606 & 1230 & 23.0 & 0.35 & 39.4 & $\star$ & $\star$ & $\star$ & $\star$ & $\star$ \\
\hline 900612 & 1305 & * & 0.35 & 39.4 & $\star$ & * & $\star$ & * & $\star$ \\
\hline 900613 & 830 & 13.0 & 0.38 & 44.7 & 170 & 1940 & CI & 7.6 & 44.7 \\
\hline 900618 & 1610 & $\star$ & 0.33 & 36.3 & $\star$ & * & $\star$ & $\star$ & $\star$ \\
\hline 900622 & 1200 & * & 0.36 & 41.3 & * & * & $\star$ & * & $\star$ \\
\hline 900629 & 1340 & * & 0.35 & 39.4 & * & * & $\star$ & * & $\star$ \\
\hline 900706 & 1350 & $\star$ & 0.34 & 37.9 & * & * & $\star$ & * & $\star$ \\
\hline 900719 & 1453 & $\star$ & 0.39 & 46.4 & $\star$ & $\star$ & $\star$ & $\star$ & $\star$ \\
\hline 900725 & 830 & 17.0 & 0.38 & 44.7 & 170 & 2040 & $\mathrm{CI}$ & 7.6 & 44.7 \\
\hline 900906 & 840 & 17.5 & 0.37 & 43.0 & 170 & 2060 & CI & 7.3 & 42.9 \\
\hline N & & 66 & 68 & 80 & 84 & 22 & $\star$ & 35 & 35 \\
\hline MraN & & 15.7 & 0.35 & 41.9 & 170 & 2047 & $\star$ & 7.3 & 42.9 \\
\hline STANDARD & DBVIATION & 5.5 & 0.05 & 15.0 & 3.9 & 55 & $\star$ & 3.4 & 20.0 \\
\hline MONINOY & & 4.0 & 0.25 & 19.8 & 160 & 1940 & $\star$ & 4.0 & 23.5 \\
\hline $\operatorname{Max} \operatorname{sux}$ & & 28.0 & 0.55 & 104.7 & 180 & 2152 & $\star$ & 17.9 & 105.3 \\
\hline
\end{tabular}


Table G-2. Hydrologic monitoring data for Hot River (site name Hot River near Mammoth) in Yellowstone National Park

Sample Date: Listed by year, month, and day.

Gage Height: Reported in feet; multiply by 0.305 to obtain meters.

Discharge: Calculated from gage height after January 1, 1987; measured on September 4, 1986.

Laboratory: NORT, data supplied by Dan Norton, U.S. Geological Survey, Denver, Colorado, based on corrected values from analyses by U.S. Geological Survey Central Laboratory, Arvada, Colorado; CL, U.S. Geological Survey Central Laboratory, Arvada, Colorado; ING, U.S. Geological Survey laboratory, Menlo Park, California, under the direction of W.C. Evans; YK, U.S. Geological Survey laboratory, Menlo Park, California, under the direction of Y.K. Kharaka. Chloride Flux: Discharge times chloride concentration.

Thermal Discharge: Chloride flux divided by $170 \mathrm{mg} / \mathrm{L}$.

$[\mathrm{L} / \mathrm{s}$, liters per second; $\mu \mathrm{S} / \mathrm{cm}$, microsiemens per centimeter; $\mathrm{g} / \mathrm{s}$, grams per second; * , no data]

\begin{tabular}{|c|c|c|c|c|c|c|c|c|c|}
\hline $\begin{array}{c}\text { Sample } \\
\text { Date }\end{array}$ & $\begin{array}{l}\text { Sample } \\
\text { Time } \\
\text { (hour) }\end{array}$ & $\begin{array}{c}\text { Water } \\
\text { Temperature } \\
\text { (Celsius) }\end{array}$ & $\begin{array}{l}\text { Gage } \\
\text { Height } \\
\text { (feet) }\end{array}$ & $\begin{array}{c}\text { Dis- } \\
\text { charge } \\
(\mathrm{L} / \mathrm{s})\end{array}$ & $\begin{array}{l}\text { Chloride } \\
\text { (mg/L) }\end{array}$ & $\begin{array}{l}\text { Conduct- } \\
\text { ance } \\
(\mu \mathrm{S} / \mathrm{cm})\end{array}$ & $\begin{array}{l}\text { Labo- } \\
\text { ratory }\end{array}$ & $\begin{array}{c}\text { Chloride } \\
\text { Flux } \\
\text { (g/s) }\end{array}$ & $\begin{array}{r}\text { Therm } \\
\text { Discha } \\
\text { (L/s }\end{array}$ \\
\hline 860613 & 1000 & 39.5 & * & $\star$ & * & $\star$ & $\star$ & $\star$ & $\star$ \\
\hline 860613 & 1630 & 41.5 & * & $\star$ & * & * & * & $\star$ & * \\
\hline 860618 & 930 & 44.0 & * & $\star$ & * & $\star$ & * & $\star$ & $\star$ \\
\hline 860618 & 1320 & 45.0 & * & * & * & * & * & $\star$ & * \\
\hline 860619 & 1015 & 45.5 & * & $\star$ & * & * & $\star$ & * & $\star$ \\
\hline 860620 & 700 & 45.5 & * & $\star$ & * & * & * & * & $\star$ \\
\hline 860624 & 900 & 45.5 & * & $\star$ & * & $\star$ & * & * & $\star$ \\
\hline 860625 & 1115 & 45.5 & * & $\star$ & $\star$ & $\star$ & $\star$ & $\star$ & $\star$ \\
\hline 860626 & 915 & 45.0 & * & * & $\star$ & * & $\star$ & $\star$ & $\star$ \\
\hline 860629 & 1030 & 46.0 & $\star$ & $\star$ & $\star$ & * & $\star$ & $\star$ & $\star$ \\
\hline 860703 & $\star$ & 49.0 & * & * & * & $\star$ & * & * & $\star$ \\
\hline 860708 & $\star$ & 49.0 & $\star$ & $\star$ & $\star$ & $\star$ & $\star$ & $\star$ & $\star$ \\
\hline 860710 & $\star$ & 49.0 & * & $\star$ & $\star$ & * & * & $\star$ & $\star$ \\
\hline 860714 & * & 48.5 & $\star$ & $\star$ & $\star$ & * & * & $\star$ & $\star$ \\
\hline 860716 & * & 48.5 & $\star$ & $\star$ & $\star$ & * & * & $\star$ & $\star$ \\
\hline 860721 & $\star$ & 48.5 & $\star$ & * & * & $\star$ & $\star$ & $\star$ & $\star$ \\
\hline 860723 & $\star$ & 49.5 & $\star$ & $\star$ & * & $\star$ & * & * & $\star$ \\
\hline 860728 & $\star$ & 47.5 & $\star$ & * & * & $\star$ & * & $\star$ & $\star$ \\
\hline 860729 & $\star$ & 47.5 & $\star$ & $\star$ & * & $\star$ & * & * & $\star$ \\
\hline 860730 & $\star$ & 47.5 & $\star$ & $\star$ & $\star$ & $\star$ & * & $\star$ & * \\
\hline 860804 & * & 48.0 & $\star$ & $\star$ & * & * & * & * & $\star$ \\
\hline 860812 & * & 48.0 & $\star$ & $\star$ & $\star$ & $\star$ & $\star$ & $\star$ & $\star$ \\
\hline 860904 & * & $\star$ & 1.22 & 612 & 122 & $\star$ & NORT & 74.7 & 439 \\
\hline 860930 & $\star$ & 48.0 & * & * & * & $\star$ & * & * & * \\
\hline 870115 & 1230 & * & 1.22 & 612 & 134 & $\star$ & NORT & 82.0 & 482 \\
\hline 870129 & $\star$ & $\star$ & 1.20 & 583 & 134 & $\star$ & NORT & 78.1 & 460 \\
\hline 870204 & $\star$ & $\star$ & 1.21 & 597 & 133 & $\star$ & NORT & 79.4 & 467 \\
\hline 870226 & 915 & * & 1.19 & 570 & 144 & $\star$ & NORT & 82.1 & 483 \\
\hline 870306 & 830 & 50.0 & 1.24 & 640 & 132 & $\star$ & NORT & 84.5 & 497 \\
\hline 870313 & * & * & 1.26 & 668 & 136 & $\star$ & NORT & 90.8 & 534 \\
\hline 870321 & 1810 & 50.5 & 1.25 & 654 & 133 & $\star$ & NORT & 87.0 & 512 \\
\hline 870401 & $\star$ & 52.5 & 1.24 & 640 & 138 & $\star$ & NORT & 88.3 & 520 \\
\hline 870410 & $\star$ & 52.5 & 1.24 & 640 & 137 & $\star$ & NORT & 87.7 & 516 \\
\hline 870416 & $\star$ & 49.5 & 1.25 & 654 & 132 & $\star$ & NORI & 86.3 & 508 \\
\hline
\end{tabular}




\begin{tabular}{|c|c|c|c|c|c|c|c|c|c|}
\hline $\begin{array}{c}\text { Sample } \\
\text { Date }\end{array}$ & $\begin{array}{c}\text { Sample } \\
\text { Time } \\
\text { (hour) }\end{array}$ & $\begin{array}{c}\text { Water } \\
\text { Temperature } \\
\text { (Celsius) }\end{array}$ & $\begin{array}{l}\text { Gage } \\
\text { Height } \\
\text { (feet) }\end{array}$ & $\begin{array}{c}\text { Dis- } \\
\text { charge } \\
(\mathrm{L} / \mathrm{s})\end{array}$ & $\begin{array}{l}\text { Chloride } \\
(\mathrm{mg} / \mathrm{L})\end{array}$ & $\begin{array}{l}\text { Conduct- } \\
\text { ance } \\
(\mu \mathrm{S} / \mathrm{cm})\end{array}$ & $\begin{array}{l}\text { Labo- } \\
\text { ratory }\end{array}$ & $\begin{array}{l}\text { Chloride } \\
\text { Flux } \\
\text { (g/s) }\end{array}$ & $\begin{array}{c}\text { Thermal } \\
\text { Discharge } \\
(\mathrm{L} / \mathrm{s})\end{array}$ \\
\hline 870421 & $\star$ & 49.0 & 1.26 & 668 & 137 & * & NORT & 91.5 & 538 \\
\hline 870429 & $\star$ & 47.0 & 1.30 & 725 & 126 & * & NORT & 91.4 & 537 \\
\hline 870506 & 2030 & 49.0 & 1.30 & 725 & 128 & $\star$ & NORT & 92.8 & 546 \\
\hline 870512 & 630 & 48.0 & 1.32 & 753 & 122 & $\star$ & NORT & 91.9 & 540 \\
\hline 870527 & * & 46.0 & 1.31 & 739 & 120 & $\star$ & NORT & 88.7 & 522 \\
\hline 870602 & $\star$ & 46.0 & 1.32 & 753 & 119 & * & NORT & 89.6 & 527 \\
\hline 870611 & $\star$ & 48.5 & 1.32 & 753 & 119 & $\star$ & MORT & 89.6 & 527 \\
\hline 870619 & $\star$ & $\star$ & 1.30 & 725 & 123 & $\star$ & NORT & 89.2 & 525 \\
\hline 870623 & $\star$ & 49.0 & 1.29 & 711 & 121 & $\star$ & KORT & 86.0 & 506 \\
\hline 870702 & $\star$ & 48.0 & 1.30 & 725 & 120 & $\star$ & NORT & 87.0 & 512 \\
\hline 870708 & $\star$ & 48.0 & 1.30 & 725 & 123 & $\star$ & MORT & 89.2 & 525 \\
\hline 870717 & 1130 & 48.0 & 1.30 & 725 & 124 & $\star$ & NORT & 89.9 & 529 \\
\hline 870723 & 1045 & 48.0 & 1.31 & 739 & 124 & $\star$ & MORT & 91.6 & 539 \\
\hline 870731 & 1030 & 47.0 & 1.31 & 739 & 124 & $\star$ & NORT & 91.6 & 539 \\
\hline 870807 & 1030 & 48.0 & 1.31 & 739 & 125 & $\star$ & NORT & 92.4 & 543 \\
\hline 870812 & 930 & 47.0 & 1.32 & 753 & 123 & $\star$ & NORT & 92.6 & 545 \\
\hline 870819 & 1415 & 47.5 & 1.34 & 782 & 125 & $\star$ & NORT & 97.8 & 575 \\
\hline 870828 & 1500 & 48.5 & 1.32 & 753 & 124 & $\star$ & MORT & 93.4 & 549 \\
\hline 870903 & * & * & 1.32 & 753 & 121 & $\star$ & MORT & 91.1 & 536 \\
\hline 870909 & 830 & 47.0 & 1.33 & 767 & 122 & $\star$ & NORT & 93.6 & 550 \\
\hline 870919 & * & $\star$ & 1.34 & 782 & 120 & $\star$ & MORT & 94.8 & 552 \\
\hline 870923 & 930 & 46.0 & 1.32 & 753 & 123 & * & NORT & 92.6 & 545 \\
\hline 870930 & 1000 & 46.0 & 1.32 & 753 & 122. & * & MORT & 91.9 & 540 \\
\hline 871006 & 1020 & 47.0 & 1.32 & 753 & 122 & * & NORT & 91.9 & 540 \\
\hline 871023 & 1900 & 48.0 & 1.32 & 753 & 130 & $\star$ & NORT & 97.9 & 576 \\
\hline 871105 & * & $\star$ & 1.32 & 753 & 127 & * & NORT & 95.6 & 563 \\
\hline 871203 & * & * & 1.32 & 753 & 127 & * & NORT & 95.6 & 563 \\
\hline 880106 & 1610 & 44.5 & 1.30 & 725 & 132 & $\star$ & NORT & 95.7 & 563 \\
\hline 880205 & * & $\star$ & 1.28 & 697 & 139 & $\star$ & NORT & 96.9 & 570 \\
\hline 880212 & $\star$ & $\star$ & 1.25 & 654 & 141 & $\star$ & NORT & 92.2 & 542 \\
\hline 880221 & $\star$ & $\star$ & 1.26 & 668 & 135 & $\star$ & NORT & 90.2 & 530 \\
\hline 880314 & $\star$ & 46.0 & 1.32 & 753 & 126 & $\star$ & MORT & 94.9 & 558 \\
\hline 880328 & $\star$ & 46.0 & 1.34 & 782 & 122 & $\star$ & NORT & 95.4 & 560 \\
\hline 880516 & $\star$ & 40.0 & 1.40 & 866 & 101 & $\star$ & NORT & 87.5 & 515 \\
\hline 880524 & $\star$ & 42.0 & 1.40 & 866 & 101 & $\star$ & NORT & 87.5 & 515 \\
\hline 880623 & 1000 & 44.0 & 1.40 & 866 & 105 & $\star$ & NORT & 90.9 & 535 \\
\hline 880804 & 1450 & 44.0 & 1.38 & 839 & * & * & * & * & * \\
\hline 880811 & 1150 & 44.0 & 1.39 & 853 & $\star$ & $\star$ & * & $\star$ & $\star$ \\
\hline 880818 & 957 & 42.0 & 1.40 & 866 & $\star$ & $\star$ & $\star$ & $\star$ & $\star$ \\
\hline 880825 & 1330 & 43.0 & 1.38 & 839 & $\star$ & $\star$ & * & * & * \\
\hline 880901 & 930 & 44.0 & 1.39 & 852 & $\star$ & $\star$ & * & * & * \\
\hline 880908 & 1055 & 41.5 & 1.39 & 852 & * & $\star$ & * & * & * \\
\hline 880914 & 1300 & 42.0 & 1.39 & 852 & 111 & 1580 & CI & 94.6 & 556 \\
\hline 880915 & 1500 & 42.5 & 1.39 & 852 & * & * & * & $\star$ & * \\
\hline 880922 & 955 & 42.0 & 1.39 & 852 & $\star$ & $\star$ & * & $\star$ & $\star$ \\
\hline 880929 & 1035 & 41.5 & 1.39 & 852 & $\star$ & * & * & $\star$ & $\star$ \\
\hline 881005 & 1538 & 42.0 & 1.38 & 838 & 108 & 1550 & CL & 89.9 & 532 \\
\hline 881006 & 1200 & 41.6 & 1.39 & 852 & 110 & * & NORT & 93.7 & 551 \\
\hline 881013 & 930 & 41.4 & 1.39 & 852 & 110 & $\star$ & NORT & 93.7 & 551 \\
\hline 881020 & 846 & 40.7 & 1.39 & 852 & 110 & $\star$ & MORT & 93.7 & 551 \\
\hline 881027 & 915 & 40.3 & 1.39 & 852 & 110 & $\star$ & MORT & 93.7 & 551 \\
\hline 881101 & 845 & $\star$ & 1.37 & 824 & 110 & * & NORT & 90.6 & 533 \\
\hline 881101 & 1000 & 40.5 & 1.37 & 824 & 111 & 1670 & CL & 91.5 & 538 \\
\hline 881118 & 1100 & 39.9 & 1.37 & 824 & 120 & $\star$ & NORT & 98.9 & 582 \\
\hline
\end{tabular}


Sample Sample Water Gage Dis- Chloride Conduct- Labo- Chloride Thermal Date Time Temperature Height charge $(\mathrm{mg} / \mathrm{L})$ ance ratory Flux Discharge

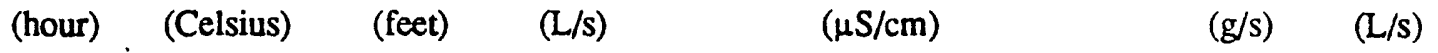

\begin{tabular}{|c|c|c|c|c|c|c|c|c|c|}
\hline 881205 & 1345 & 39.5 & 1.34 & 782 & 110 & 1660 & CI & 86.0 & 506 \\
\hline 881215 & 1045 & $\star$ & 1.28 & 697 & $\star$ & 1800 & CI & $\star$ & $\star$ \\
\hline 881216 & 1220 & 42.5 & 1.35 & 796 & 120 & * & NORT & 95.5 & 562 \\
\hline 881229 & 1656 & 40.0 & 1.38 . & 839 & $\star$ & $\star$ & * & * & * \\
\hline 890113 & 1600 & 40.0 & 1.36 & 810 & 112 & $\star$ & NORT & 90.7 & 534 \\
\hline 890113 & 1600 & 40.0 & 1.36 & 810 & 112 & 1640 & CI & 90.7 & 534 \\
\hline 890127 & 1715 & 40.0 & 1.40 & 866 & 110 & * & NORT & 95.3 & 560 \\
\hline 890214 & 925 & 41.5 & 1.34 & 784 & 120 & 1830 & NORT & 94.1 & 553 \\
\hline 890306 & 1153 & 42.0 & 1.34 & 782 & 120 & 1910 & NORT & 93.8 & 552 \\
\hline 890313 & 1530 & 43.0 & 1.31 & 739 & 120 & 1810 & CI & 88.7 & 522 \\
\hline 890330 & 1120 & 44.0 & 1.33 & 767 & 120 & * & NORT & 92.0 & 541 \\
\hline 890411 & 1245 & 44.0 & 1.33 & 767 & 122 & 1840 & CL & 93.6 & 550 \\
\hline 890427 & 1345 & 48.0 & 1.31 & 739 & $\star$ & * & * & $\star$ & * \\
\hline 890505 & 1620 & 49.0 & 1.29 & 711 & * & * & * & * & * \\
\hline 890509 & 1030 & 41.0 & 1.38 & 838 & 105 & 1610 & CI & 88.0 & 518 \\
\hline 890512 & 1100 & 42.0 & 1.40 & 859 & $\star$ & $\star$ & * & $\star$ & * \\
\hline 890522 & 905 & 44.0 & 1.35 & 797 & $\star$ & $\star$ & $\star$ & $\star$ & $\star$ \\
\hline 890524 & 1420 & 42.5 & 1.38 & 838 & $\star$ & $\star$ & * & $\star$ & * \\
\hline 890605 & 1600 & 43.0 & 1.32 & 753 & * & $\star$ & * & * & * \\
\hline 890606 & 1415 & 42.0 & 1.36 & 810 & 106 & 1550 & $C L$ & 85.9 & 505 \\
\hline 890615 & 1327 & 43.0 & 1.35 & 797 & $\star$ & $\star$ & * & $\star$ & * \\
\hline 890622 & 1550 & 41.8 & 1.35 & 797 & $\star$ & $\star$ & $\star$ & $\star$ & * \\
\hline 890626 & 1420 & 43.5 & 1.33 & 760 & * & $\star$ & * & $\star$ & * \\
\hline 890626 & 1420 & 43.5 & 1.33 & 760 & 107 & $\star$ & ING & 81.3 & 478 \\
\hline 890626 & $\star$ & $\star$ & 1.33 & 760 & 105 & 1590 & $\mathrm{r}$ & 79.8 & 469 \\
\hline 890630 & 1605 & 44.0 & 1.33 & 767 & * & $\star$ & * & * & * \\
\hline 890705 & 1515 & 44.5 & 1.31 & 739 & 109 & 1640 & CI & 80.6 & 474 \\
\hline 890714 & 825 & 44.5 & 1.32 & 753 & * & * & * & * & * \\
\hline 890720 & 840 & 45.5 & 1.32 & 753 & $\star$ & * & * & $\star$ & * \\
\hline 890720 & 840 & 45.5 & 1.32 & 753 & 105 & 1590 & ING & 79.1 & 465 \\
\hline 890728 & 1315 & 46.0 & 1.31 & 739 & $\star$ & $\star$ & ^ & • & * \\
\hline 890803 & 1043 & 46.0 & 1.31 & 739 & $\star$ & * & * & * & * \\
\hline 890808 & 1500 & 45.5 & 1.32 & 753 & 116 & 1700 & CI & 87.3 & 514 \\
\hline 890817 & 1210 & 45.5 & 1.31 & 739 & * & * & * & * & * \\
\hline 890823 & 1000 & 47.5 & 1.28 & 697 & $\star$ & $\star$ & * & ๘ & * \\
\hline 890823 & 1000 & 47.5 & 1.28 & 697 & 112 & 1760 & ING & 78.1 & 459 \\
\hline 890831 & 1400 & 48.5 & 1.28 & 697 & * & $\star$ & * & * & * \\
\hline 890905 & Ł & * & 1.27 & 682 & $\star$ & * & * & $\star$ & * \\
\hline 890908 & 1050 & 48.5 & 1.27 & 682 & 122 & 1810 & $\mathbf{Y K}$ & 83.2 & 489 \\
\hline 890911 & 1500 & 47.5 & 1.27 & 682 & 124 & 1900 & $C L$ & 84.6 & 497 \\
\hline 890915 & 1410 & 48.0 & 1.28 & 697 & * & * & * & $\star$ & * \\
\hline 890922 & 1410 & 48.0 & 1.27 & 682 & * & $\star$ & $\star$ & $\star$ & * \\
\hline 890928 & 940 & 48.0 & 1.26 & 668 & * & * & * & $\star$ & * \\
\hline 891003 & 1400 & 47.0 & 1.27 & 682 & 121 & 1760 & CI & 82.5 & 486 \\
\hline 891018 & 1355 & 48.5 & 1.25 & 654 & * & $\star$ & $\star$ & * & * \\
\hline 891018 & 1355 & 48.5 & 1.25 & 654 & 128 & 1780 & ING & 83.7 & 492 \\
\hline 891103 & 1430 & 48.5 & 1.25 & 646 & * & * & ^ & * & * \\
\hline 891115 & 1239 & 48.3 & 1.24 & 640 & 132 & 1880 & Cr & 84.5 & 497 \\
\hline 891213 & 1500 & 44.0 & 1.29 & 711 & * & * & * & * & * \\
\hline 891213 & 1500 & 44.0 & 1.29 & 711 & 120 & 1700 & ING & 85.3 & 502 \\
\hline 900103 & 1400 & 47.0 & 1.29 & 711 & 115 & 1760 & CI & 81.8 & 481 \\
\hline 900117 & 1310 & 43.0 & 1.27 & 682 & * & $\star$ & * & $\star$ & * \\
\hline 900130 & 1150 & 44.5 & 1.27 & 682 & $\star$ & * & * & $\star$ & * \\
\hline 900130 & 1150 & 44.5 & 1.27 & 682 & 122 & 1600 & ING & 83.2 & 489 \\
\hline
\end{tabular}


Table G-2.--Hydrologic monitoring data for Hot River--continued

\begin{tabular}{|c|c|c|c|c|c|c|c|c|c|}
\hline $\begin{array}{c}\text { Sample } \\
\text { Date }\end{array}$ & $\begin{array}{l}\text { Sample } \\
\text { Time } \\
\text { (hour) }\end{array}$ & $\begin{array}{c}\text { Water } \\
\text { Temperature } \\
\text { (Celsius) }\end{array}$ & $\begin{array}{l}\text { Gage } \\
\text { Height } \\
\text { (feet) }\end{array}$ & $\begin{array}{c}\text { Dis- } \\
\text { charge } \\
(\mathrm{L} / \mathrm{s})\end{array}$ & $\begin{array}{l}\text { Chloride } \\
(\mathrm{mg} / \mathrm{L})\end{array}$ & $\begin{array}{l}\text { Conduct- } \\
\text { ance } \\
(\mu \mathrm{S} / \mathrm{cm})\end{array}$ & $\begin{array}{l}\text { Labo- } \\
\text { ratory }\end{array}$ & $\begin{array}{c}\text { Chloride } \\
\text { Flux } \\
(\mathrm{g} / \mathrm{s})\end{array}$ & $\begin{array}{c}\text { Thermal } \\
\text { Discharge } \\
(\mathrm{L} / \mathrm{s})\end{array}$ \\
\hline 900202 & $\star$ & 55.0 & 1.15 & 518 & $\star$ & 2090 & CI & $\star$ & * \\
\hline 900216 & 1030 & 44.0 & 1.29 & 711 & 115 & 1780 & CL & 81.8 & 481 \\
\hline 900219 & 1415 & 46.5 & 1.28 & 697 & $\star$ & $\star$ & $\star$ & $\star$ & * \\
\hline 900307 & 1309 & 46.0 & 1.29 & 711 & 126 & 1600 & ING & 89.6 & 527 \\
\hline 900327 & 1415 & 51.5 & 1.21 & 597 & $\star$ & $\star$ & $\star$ & $\star$ & $\star$ \\
\hline 900329 & 900 & 51.0 & 1.21 & 597 & $\star$ & $\star$ & $\star$ & $\star$ & $\star$ \\
\hline 900404 & 1445 & 48.0 & 1.24 & 640 & 134 & 1880 & CI & 85.8 & 504 \\
\hline 900413 & 1105 & 42.0 & 1.31 & 739 & $\star$ & $\star$ & $\star$ & * & * \\
\hline 900418 & 1015 & 39.0 & 1.34 & 782 & $\star$ & $\star$ & $\star$ & $\star$ & $\star$ \\
\hline 900425 & 900 & 40.5 & 1.37 & 824 & $\star$ & * & $\star$ & * & $\star$ \\
\hline 900507 & 1245 & $\star$ & 1.33 & 767 & $\star$ & $\star$ & $\star$ & $\star$ & $\star$ \\
\hline 900509 & 1730 & 42.0 & 1.33 & 767 & 106 & 1620 & $C I$ & 81.3 & 478 \\
\hline 900517 & 1415 & 42.5 & 1.34 & 782 & $\star$ & $\star$ & $\star$ & $\star$ & * \\
\hline 900522 & 1230 & $\star$ & 1.33 & 767 & $\star$ & * & $\star$ & $\star$ & $\star$ \\
\hline 900529 & 1055 & 40.0 & 1.32 & 753 & $\star$ & $\star$ & $\star$ & $\star$ & $\star$ \\
\hline 900606 & 1430 & $\star$ & 1.32 & 753 & $\star$ & $\star$ & $\star$ & * & $\star$ \\
\hline 900612 & 1020 & $\star$ & 1.30 & 725 & $\star$ & $\star$ & $\star$ & $\star$ & $\star$ \\
\hline 900612 & 1527 & $\star$ & 1.33 & 767 & $\star$ & $\star$ & $\star$ & * & $\star$ \\
\hline 900613 & 1400 & 42.0 & 1.33 & 767 & 107 & 1550 & CI & 82.1 & 483 \\
\hline 900613 & $\star$ & $\star$ & 1.33 & 767 & 105 & * & Yx & 80.5 & 474 \\
\hline 900622 & 1330 & $\star$ & 1.33 & 767 & $\star$ & * & $\star$ & $\star$ & $\star$ \\
\hline 900629 & 1100 & * & 1.33 & 767 & $\star$ & $\star$ & $\star$ & * & $\star$ \\
\hline 900706 & 930 & 44.0 & 1.33 & 767 & $\star$ & 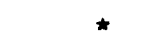 & * & $\star$ & $\star$ \\
\hline 900725 & 1200 & 43.5 & 1.34 & 753 & 107 & 1630 & CL & 80.6 & 474 \\
\hline 900906 & 1240 & 44.0 & 1.35 & 796 & 106 & 1660 & CL & 84.4 & 496 \\
\hline $\mathrm{N}$ & & 141 & 144 & 144 & 90 & 33 & $\star$ & 90 & 90 \\
\hline MEAY & & 45.3 & 1.31 & 745 & 120 & 1719 & $\star$ & 88.8 & 522 \\
\hline STANDARD & DEVIATION & 3.2 & 0.05 & 71 & 10 & 130 & $\star$ & 5.4 & 32 \\
\hline MINIMUX & & 39.0 & 1.15 & 518 & 101 & 1550 & $\star$ & 74.7 & 439 \\
\hline MaXndOX & & 55.0 & 1.40 & 866 & 144 & 2090 & $\star$ & 98.9 & 582 \\
\hline
\end{tabular}


Table G-3. Hydrologic monitoring data for La Duke Hot Spring (site name LaDuke (Corwin) Hot Springs near Corwin Springs, MT)

Sample Date: Listed by year, month, and day.

Gage Height: Reported in feet; multiply by 0.305 to obtain meters.

Discharge: Calculated from gage height at weir below culvert after September 5, 1987; measured on and before that date.

Laboratory: NORT, data supplied by Dan Norton, U.S. Geological Survey, Denver, Colorado, based on corrected values from analyses by U.S. Geological Survey Central Laboratory, Arvada, Colorado; CL, U.S. Geological Survey Central Laboratory, Arvada, Colorado; ING, U.S. Geological Survey laboratory, Menlo Park, California, under the direction of W.C. Evans; YK, U.S. Geological Survey laboratory, Menlo Park, Califomia, under the direction of Y.K. Kharaka.

Chloride Flux: Discharge times chloride concentration.

[L/s, liters per second; $\mu \mathrm{S} / \mathrm{cm}$, microsiemens per centimeter; $\mathrm{g} / \mathrm{s}$, grams per second; * , no data]

\begin{tabular}{|c|c|c|c|c|c|c|c|c|}
\hline $\begin{array}{c}\text { Sample } \\
\text { Date }\end{array}$ & $\begin{array}{l}\text { Sample } \\
\text { Time } \\
\text { (hour) }\end{array}$ & $\begin{array}{c}\text { Water } \\
\text { Temperature } \\
\text { (Celsius) }\end{array}$ & $\begin{array}{l}\text { Gage } \\
\text { Height } \\
\text { (feet) }\end{array}$ & $\begin{array}{c}\text { Dis- } \\
\text { charge } \\
(\mathrm{L} / \mathrm{s})\end{array}$ & $\begin{array}{l}\text { Chloride } \\
(\mathrm{mg} / \mathrm{L})\end{array}$ & $\begin{array}{l}\text { Conduct- } \\
\text { ance } \\
(\mu \mathrm{S} / \mathrm{cm})\end{array}$ & $\begin{array}{l}\text { Labo- } \\
\text { ratory }\end{array}$ & $\begin{array}{c}\text { Chloride } \\
\text { Flux } \\
\text { (g/s) }\end{array}$ \\
\hline 860904 & * & * & * & $\star$ & 45 & * & NORT & $\star$ \\
\hline 870110 & $\star$ & * & * & $\star$ & 46 & * & MORT & $\star$ \\
\hline 870211 & * & $\star$ & * & * & 47 & $\star$ & NORT & $\star$ \\
\hline 870312 & $\star$ & * & * & $\star$ & 47 & * & MORT & $\star$ \\
\hline 870413 & $\star$ & $\star$ & $\star$ & * & 47 & * & MORT & $\star$ \\
\hline 870512 & $\star$ & * & $\star$ & * & 47 & * & MORT & $\star$ \\
\hline 870514 & $\star$ & * & * & $\star$ & 47 & $\star$ & NORT & $\star$ \\
\hline 870609 & $\star$ & $\star$ & * & * & 46 & * & MORT & * \\
\hline 870717 & $\star$ & $\star$ & $\star$ & * & 46 & * & MORT & $\star$ \\
\hline 870731 & $\star$ & * & * & * & 46 & * & MORT & * \\
\hline 870817 & $\star$ & $\star$ & * & * & 46 & * & NORT & * \\
\hline 870903 & $\star$ & * & * & 7.36 & $\star$ & * & * & * \\
\hline 870905 & $\star$ & $\star$ & * & 7.65 & $\star$ & $\star$ & $\star$ & $\star$ \\
\hline 870906 & $\star$ & * & 0.480 & 6.63 & 46 & $\star$ & NORT & 0.30 \\
\hline 870911 & $\star$ & * & * & * & 47 & * & NORT & Ł \\
\hline 870924 & $\star$ & * & 0.500 & 7.36 & $\star$ & $\star$ & $\star$ & * \\
\hline 871011 & $\star$ & * & * & * & 46 & * & NORT & * \\
\hline 871105 & * & * & 0.475 & 6.23 & 44 & * & MORT & 0.27 \\
\hline 871112 & $\star$ & $\star$ & 0.490 & 7.08 & 45 & * & MORT & 0.32 \\
\hline 871208 & $\star$ & $\star$ & 0.480 & 6.51 & $\star$ & $\star$ & * & * \\
\hline 871210 & $\star$ & $\star$ & 0.475 & 6.23 & 45 & * & NORT & 0.28 \\
\hline 871215 & $\star$ & $\star$ & 0.475 & 6.23 & * & * & * & * \\
\hline 871223 & $\star$ & $\star$ & 0.460 & 5.95 & * & * & * & * \\
\hline 871229 & $\star$ & $\star$ & 0.480 & 6.51 & 44 & * & NORT & 0.29 \\
\hline 880105 & $\star$ & $\star$ & 0.480 & 6.51 & $\star$ & $\star$ & * & * \\
\hline 880115 & $\star$ & $\star$ & 0.475 & 6.23 & 45 & * & NORT & 0.28 \\
\hline 880121 & $\star$ & $\star$ & 0.475 & 6.23 & * & $\star$ & * & $\star$ \\
\hline 880127 & $\star$ & $\star$ & 0.500 & 7.36 & 45 & * & NORT & 0.33 \\
\hline 880203 & $\star$ & $\star$ & 0.510 & 7.65 & $\star$ & * & * & * \\
\hline 880212 & $\star$ & $\star$ & 0.480 & 6.51 & 45 & * & NOR2 & 0.29 \\
\hline 880213 & $\star$ & $\star$ & 0.490 & 7.08 & 44 & * & NORT & 0.31 \\
\hline 880217 & $\star$ & $\star$ & 0.480 & 6.51 & $\star$ & $\star$ & $\star$ & $\star$ \\
\hline 880225 & $\star$ & $\star$ & 0.500 & 7.36 & $\star$ & * & $\star$ & $\star$ \\
\hline 880302 & $\star$ & $\star$ & 0.480 & 6.51 & ! $\quad *$ & $\star$ & * & $\star$ \\
\hline 880308 & $\star$ & $\star$ & 0.480 & 6.51 & 45 & $\star$ & NORT & 0.29 \\
\hline
\end{tabular}




\begin{tabular}{|c|c|c|c|c|c|c|c|c|}
\hline $\begin{array}{c}\text { Sample } \\
\text { Date }\end{array}$ & $\begin{array}{l}\text { Sample } \\
\text { Time } \\
\text { (hour) }\end{array}$ & $\begin{array}{c}\text { Water } \\
\text { Temperature } \\
\text { (Celsius) }\end{array}$ & $\begin{array}{l}\text { Gage } \\
\text { Height } \\
\text { (feet) }\end{array}$ & $\begin{array}{c}\text { Dis- } \\
\text { charge } \\
(\mathrm{L} / \mathrm{s})\end{array}$ & $\begin{array}{l}\text { Chloride } \\
\text { (mg/L) }\end{array}$ & $\begin{array}{l}\text { Conduct- } \\
\text { ance } \\
(\mu \mathrm{S} / \mathrm{cm})\end{array}$ & $\begin{array}{l}\text { Labo- } \\
\text { ratory }\end{array}$ & $\begin{array}{c}\text { Chloride } \\
\text { Flux } \\
(\mathrm{g} / \mathrm{s})\end{array}$ \\
\hline 880310 & $\star$ & $\star$ & 0.480 & 6.51 & $\star$ & $\star$ & $\star$ & * \\
\hline 880315 & * & $\star$ & 0.480 & 6.51 & $\star$ & $\star$ & $\star$ & * \\
\hline 880316 & $\star$ & $\star$ & 0.480 & 6.51 & $\star$ & $\star$ & $\star$ & * \\
\hline 880322 & $\star$ & * & 0.480 & 6.51 & * & * & $\star$ & * \\
\hline 880331 & $\star$ & * & 0.490 & 7.08 & $\star$ & * & $\star$ & * \\
\hline 880407 & $\star$ & * & 0.500 & 7.36 & $\star$ & * & $\star$ & * \\
\hline 880412 & $\star$ & $\star$ & 0.500 & 7.36 & 45 & $\star$ & NORT & 0.33 \\
\hline 880414 & $\star$ & * & 0.500 & 7.36 & * & $\star$ & * & * \\
\hline 880422 & $\star$ & * & 0.500 & 7.36 & $\star$ & * & $\star$ & * \\
\hline 880428 & $\star$ & * & 0.500 & 7.36 & $\star$ & * & $\star$ & * \\
\hline 880504 & $\star$ & * & 0.510 & 7.65 & 45 & * & NORT & 0.34 \\
\hline 880511 & $\star$ & $\star$ & 0.510 & 7.65 & $\star$ & $\star$ & $\star$ & * \\
\hline 880512 & $\star$ & * & 0.510 & 7.65 & 45 & $\star$ & NORT & 0.34 \\
\hline 880519 & $\star$ & * & 0.520 & 7.93 & $\star$ & * & * & * \\
\hline 880525 & $\star$ & $\star$ & 0.525 & 8.21 & $\star$ & $\star$ & * & * \\
\hline 880602 & $\star$ & $\star$ & 0.525 & 8.21 & * & $\star$ & $\star$ & * \\
\hline 880607 & $\star$ & * & 0.533 & 8.50 & 45 & $\star$ & NORT & 0.38 \\
\hline 880608 & $\star$ & * & 0.525 & 8.21 & $\star$ & * & $\star$ & * \\
\hline 880614 & $\star$ & $\star$ & 0.533 & 8.50 & 45 & * & NORT & 0.38 \\
\hline 880616 & $\star$ & $\star$ & 0.533 & 8.50 & $\star$ & $\star$ & $\star$ & $\star$ \\
\hline 880624 & $\star$ & $\star$ & 0.533 & 8.50 & $\star$ & * & $\star$ & $\star$ \\
\hline 880629 & $\star$ & $\star$ & 0.540 & 8.78 & $\star$ & $\star$ & $\star$ & $\star$ \\
\hline 880705 & $\star$ & * & 0.540 & 8.78 & $\star$ & * & $\star$ & * \\
\hline 880707 & $\star$ & * & 0.540 & 8.78 & $\star$ & * & $\star$ & $\star$ \\
\hline 880710 & $\star$ & * & 0.540 & 8.78 & $\star$ & $\star$ & $\star$ & $\star$ \\
\hline 880713 & $\star$ & $\star$ & 0.533 & 8.50 & $\star$ & $\star$ & $\star$ & $\star$ \\
\hline 880805 & 1046 & 66.0 & 0.540 & 8.78 & $\star$ & $\star$ & $\star$ & $\star$ \\
\hline 880812 & 1630 & 62.0 & 0.540 & 8.78 & $\star$ & $\star$ & $\star$ & $\star$ \\
\hline 880819 & 1242 & 64.5 & 0.533 & 8.50 & $\star$ & $\star$ & $\star$ & $\star$ \\
\hline 880825 & 1545 & 62.0 & 0.533 & 8.50 & $\star$ & * & $\star$ & $\star$ \\
\hline 880831 & * & * & 0.540 & 8.78 & 44 & * & NORT & 0.39 \\
\hline 880901 & 1541 & 66.0 & 0.540 & 8.78 & $\star$ & * & $\star$ & $\star$ \\
\hline 880909 & 1405 & 64.0 & 0.510 & 7.65 & $\star$ & * & $\star$ & * \\
\hline 880914 & $\star$ & 64.0 & 0.510 & 7.65 & 44 & 2490 & NORT & 0.34 \\
\hline 880916 & 1531 & 60.0 & 0.510 & 7.65 & $\star$ & $\star$ & $\star$ & $\star$ \\
\hline 880922 & 1540 & 64.0 & 0.510 & 7.65 & $\star$ & $\star$ & * & $\star$ \\
\hline 880930 & 930 & 64.0 & 0.510 & 7.65 & $\star$ & * & * & * \\
\hline 881004 & 1430 & 63.5 & 0.490 & 7.08 & 43 & 2570 & CL & 0.30 \\
\hline 881004 & $\star$ & $\star$ & 0.500 & 7.36 & 44 & $\star$ & NORT & 0.32 \\
\hline 881013 & 800 & 63.0 & $\star$ & * & $\star$ & $\star$ & * & $\star$ \\
\hline 881022 & 1420 & 63.5 & 0.500 & 7.36 & $\star$ & $\star$ & * & * \\
\hline 881027 & 1630 & 64.0 & 0.510 & 7.65 & 44 & $\star$ & NORT & 0.34 \\
\hline 881031 & 1310 & $\star$ & 0.500 & 7.36 & 44 & * & NORT & 0.32 \\
\hline 881031 & 1310 & $\star$ & 0.500 & 7.36 & 44 & 2700 & $\mathrm{CL}$ & 0.32 \\
\hline 881103 & $\star$ & $\star$ & * & $\star$ & $\star$ & $\star$ & * & $\star$ \\
\hline 881103 & 1504 & 64.5 & $\star$ & $\star$ & $\star$ & $\star$ & * & $\star$ \\
\hline 881118 & 920 & 63.0 & $\star$ & $\star$ & $\star$ & $\star$ & $\star$ & $\star$ \\
\hline 881208 & 915 & 61.5 & 0.490 & 7.08 & 45 & $\star$ & NORT & 0.32 \\
\hline 881208 & 915 & 61.5 & 0.490 & 7.08 & 44 & 2590 & CL & 0.31 \\
\hline 881210 & $\star$ & $\star$ & 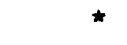 & $\star$ & 44 & $\star$ & NORT & $\star$ \\
\hline 881223 & 1603 & 63.5 & 0.510 & 7.65 & 44 & $\star$ & NORT & 0.34 \\
\hline 881227 & $\star$ & $\star$ & * & $\star$ & 45 & ๘ & NORT & $\star$ \\
\hline 890114 & 1106 & 61.5 & 0.490 & 7.08 & 43 & 2650 & CL & 0.30 \\
\hline 890114 & 1106 & 61.5 & 0.490 & 7.08 & 44 & * & NORT & 0.31 \\
\hline
\end{tabular}




$\begin{array}{ccccccccc}\text { Sample } & \text { Sample } & \text { Water } & \text { Gage } & \text { Dis- } & \text { Chloride } & \text { Conduct- } & \text { Labo- } & \text { Chloride } \\ \text { Date } & \text { Time } & \text { Temperature } & \text { Height } & \begin{array}{c}\text { charge } \\ (\mathrm{mg} / \mathrm{L})\end{array} & \begin{array}{c}\text { ance } \\ \text { ratory }\end{array} & \begin{array}{c}\text { Flux } \\ (\mathrm{g} / \mathrm{s})\end{array} \\ & \text { (hour) } & \text { (Celsius) } & \text { (feet) } & (\mathrm{L} / \mathrm{s}) & & (\mu \mathrm{S} / \mathrm{cm}) & & (\mathrm{g})\end{array}$

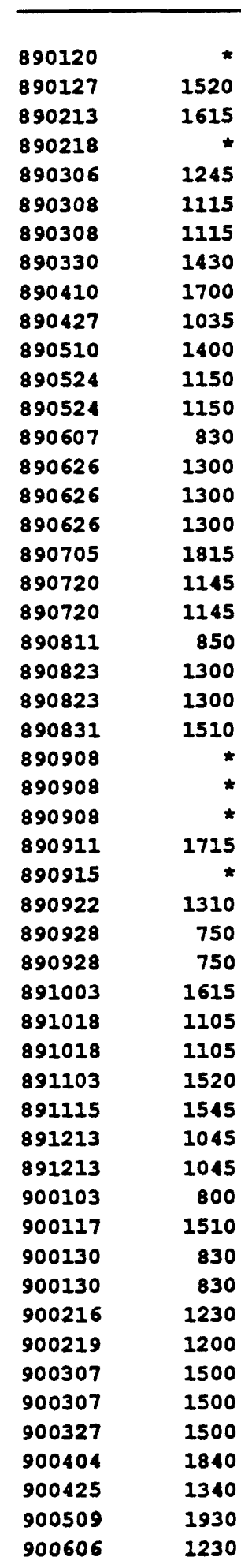

\begin{tabular}{|c|c|c|}
\hline$\star$ & $\star$ & * \\
\hline 62.0 & 0.490 & 7.08 \\
\hline 61.0 & 0.488 & 6.80 \\
\hline * & $\star$ & * \\
\hline 63.0 & 0.490 & 7.08 \\
\hline 63.5 & 0.488 & 6.80 \\
\hline 63.5 & 0.488 & 6.80 \\
\hline 62.0 & 0.488 & 6.80 \\
\hline 61.5 & 0.470 & 6.23 \\
\hline 64.0 & 0.500 & 7.36 \\
\hline 62.0 & 0.490 & 7.08 \\
\hline 65.5 & 0.490 & 7.08 \\
\hline 65.5 & 0.490 & 7.08 \\
\hline 62.0 & 0.510 & 7.65 \\
\hline 66.0 & 0.500 & 7.36 \\
\hline 66.0 & 0.500 & 7.36 \\
\hline 66.0 & 0.500 & 7.36 \\
\hline 62.5 & 0.460 & 5.95 \\
\hline 67.0 & 0.475 & 6.23 \\
\hline 67.0 & 0.475 & 6.23 \\
\hline 63.0 & 0.450 & 5.66 \\
\hline 66.5 & 0.490 & 7.08 \\
\hline 66.5 & 0.490 & 7.08 \\
\hline 64.0 & 0.430 & 5.10 \\
\hline$\star$ & 0.440 & 5.38 \\
\hline$\star$ & 0.440 & 5.38 \\
\hline$\star$ & 0.440 & 5.38 \\
\hline 62.5 & 0.440 & 5.38 \\
\hline 63.5 & 0.460 & 5.95 \\
\hline 64.0 & 0.460 & 5.95 \\
\hline 66.5 & 0.475 & 6.23 \\
\hline 66.5 & 0.475 & 6.23 \\
\hline 62.5 & 0.440 & 5.38 \\
\hline 66.5 & 0.450 & 5.66 \\
\hline 66.5 & 0.450 & 5.66 \\
\hline 64.0 & 0.460 & 5.95 \\
\hline 62.5 & 0.440 & 5.38 \\
\hline 66.0 & 0.450 & 5.66 \\
\hline 66.0 & 0.450 & 5.66 \\
\hline 62.0 & 0.450 & 5.66 \\
\hline 64.0 & 0.450 & 5.66 \\
\hline 66.0 & 0.440 & 5.38 \\
\hline 66.0 & 0.440 & 5.38 \\
\hline 61.0 & 0.440 & 5.24 \\
\hline 64.0 & 0.460 & 5.95 \\
\hline 66.0 & 0.475 & 6.23 \\
\hline 66.0 & 0.475 & 6.23 \\
\hline 63.5 & 0.475 & 6.23 \\
\hline 63.0 & 0.440 & 5.24 \\
\hline 63.0 & $\star$ & * \\
\hline 63.0 & 0.450 & 5.55 \\
\hline 66.0 & 0.475 & 6.23 \\
\hline
\end{tabular}

\begin{tabular}{|c|c|c|c|}
\hline 44 & $\star$ & NORT & $\star$ \\
\hline 43 & $\star$ & NORT & 0.30 \\
\hline 44 & $\star$ & CL & 0.30 \\
\hline 44 & $\star$ & NORT & * \\
\hline 44 & $\star$ & NORT & 0.31 \\
\hline 44 & $\star$ & NORT & 0.30 \\
\hline 43 & 2700 & CI & 0.29 \\
\hline 44 & $\star$ & NORT & 0.30 \\
\hline 43 & 2640 & CI & 0.27 \\
\hline$\star$ & $\star$ & $\star$ & * \\
\hline 43 & 2580 & CL & 0.30 \\
\hline 44 & $\star$ & NORT & 0.31 \\
\hline$\star$ & $\star$ & $\star$ & 0.35 \\
\hline 41 & 2540 & CL & 0.31 \\
\hline$\star$ & $\star$ & $\star$ & $\star$ \\
\hline 45 & 2580 & YK & 0.33 \\
\hline 43 & $\star$ & ING & 0.32 \\
\hline 44 & 2610 & CI & 0.26 \\
\hline$\star$ & $\star$ & $\star$ & $\star$ \\
\hline 45 & $\star$ & ING & 0.28 \\
\hline 41 & 2490 & CL & 0.23 \\
\hline$\star$ & $\star$ & $\star$ & $\star$ \\
\hline 45 & $\star$ & ING & 0.32 \\
\hline$\star$ & $\star$ & $\star$ & $\star$ \\
\hline$\star$ & $\star$ & $\star$ & $\star$ \\
\hline$\star$ & $\star$ & $\star$ & $\star$ \\
\hline 44 & 2570 & $\mathbf{Y X}$ & 0.24 \\
\hline 41 & 2650 & CL & 0.22 \\
\hline$\star$ & $\star$ & $\star$ & $\star$ \\
\hline$\star$ & $\star$ & $\star$ & $\star$ \\
\hline$\star$ & $\star$ & $\star$ & $\star$ \\
\hline 45 & $\star$ & ING & 0.28 \\
\hline 42 & 2610 & $C L$ & 0.23 \\
\hline$\star$ & $\star$ & $\star$ & $\star$ \\
\hline 45 & $\star$ & ING & 0.25 \\
\hline$\star$ & $\star$ & $\star$ & $\star$ \\
\hline 44 & 2580 & CL & 0.24 \\
\hline$\star$ & $\star$ & $\star$ & $\star$ \\
\hline 45 & $\star$ & ING & 0.25 \\
\hline 45 & 2680 & CE & 0.25 \\
\hline$\star$ & $\star$ & $\star$ & $\star$ \\
\hline$\star$ & $\star$ & $\star$ & $\star$ \\
\hline 45 & $\star$ & ING & 0.24 \\
\hline 46 & 2810 & CL & 0.24 \\
\hline$\star$ & $\star$ & $\star$ & * \\
\hline 45 & $\star$ & ING & 0.28 \\
\hline$\star$ & $\star$ & $\star$ & * \\
\hline$\star$ & $\star$ & $\star$ & $\star$ \\
\hline 45 & 2600 & CI & 0.24 \\
\hline$\approx$ & $\star$ & $\star$ & $\star$ \\
\hline $\begin{array}{r}42 \\
\star\end{array}$ & $\begin{array}{r}2600 \\
\star\end{array}$ & ${ }^{C I}$ & 0.23 \\
\hline
\end{tabular}


Table G-3.--Hydrologic monitoring data for La Duke Hot Spring--continued

\begin{tabular}{|c|c|c|c|c|c|c|c|c|}
\hline $\begin{array}{c}\text { Sample } \\
\text { Date }\end{array}$ & $\begin{array}{l}\text { Sample } \\
\text { Time } \\
\text { (hour) }\end{array}$ & $\begin{array}{c}\text { Water } \\
\text { Temperature } \\
\text { (Celsius) }\end{array}$ & $\begin{array}{l}\text { Gage } \\
\text { Height } \\
\text { (feet) }\end{array}$ & $\begin{array}{c}\text { Dis- } \\
\text { charge } \\
(\mathrm{L} / \mathrm{s})\end{array}$ & $\begin{array}{l}\text { Chloride } \\
(\mathrm{mg} / \mathrm{L})\end{array}$ & $\begin{array}{l}\text { Conduct- } \\
\text { ance } \\
(\mu \mathrm{S} / \mathrm{cm})\end{array}$ & $\begin{array}{l}\text { Labo- } \\
\text { ratory }\end{array}$ & $\begin{array}{l}\text { Chloride } \\
\text { Flux } \\
(\mathrm{g} / \mathrm{s})\end{array}$ \\
\hline 900613 & 1830 & 63.0 & 0.460 & 5.86 & 43 & 2550 & CI & 0.25 \\
\hline 900706 & 1326 & 67.0 & 0.440 & 5.38 & $\star$ & * & * & $\star$ \\
\hline 900725 & 1630 & 63.0 & 0.460 & 5.95 & 46 & 2550 & CI & 0.27 \\
\hline $\mathbf{N}$ & & 71 & 120 & 122 & 76 & 23 & $\star$ & 59 \\
\hline Meas & & 64.0 & 0.488 & 6.91 & 45 & 2604 & * & 0.30 \\
\hline STAMDARD & DEVIATION & 1.8 & 0.029 & 1.01 & 1.5 & 73 & $\star$ & 0.04 \\
\hline mornom & & 60.0 & 0.430 & 5.10 & 41 & 2490 & $\star$ & 0.22 \\
\hline Maxmox & & 67.0 & 0.540 & 8.78 & 51 & 2810 & * & 0.39 \\
\hline
\end{tabular}


Table G-4. Concentrations of selected chemical components in waters sampled from the Yellowstone River, Gardner River, and Bear Creek and calculated values of thermal-water discharge into the Yellowstone River between its confluence with Bear Creek and the gaging station at Corwin Springs

Concentrations: Reported in milligrams per liter.

Site abbreviations: YR (Yellowstone River), BC (Bear Creek), GR (Gardner River), QW (Queen of the Waters), CS (Corwin Springs), us (upstream), ds (downstream).

$$
[\mathrm{L} / \mathrm{s} \text {, liters per second] }
$$

\begin{tabular}{|c|c|c|c|c|c|c|c|}
\hline \multirow[t]{2}{*}{ Date } & \multirow{2}{*}{$\begin{array}{l}\text { Sampling } \\
\text { Site }\end{array}$} & \multicolumn{4}{|c|}{ Concentration $^{2}$} & \multirow{2}{*}{$\begin{array}{c}\text { Stream } \\
\text { flow } \\
(\mathrm{L} / \mathrm{s})\end{array}$} & \multirow{2}{*}{$\begin{array}{c}\text { Thermal } \\
\text { Water } \\
\text { Discharg } \\
(\mathrm{L} / \mathrm{s})\end{array}$} \\
\hline & & $\mathrm{SO}_{4}$ & $\mathrm{Cl}$ & $\mathrm{Ca}$ & $\mathrm{Na}$ & & \\
\hline \multirow[t]{2}{*}{$9 / 12 / 89$} & YR at QW & 23.59 & 10.15 & 13.67 & 17.83 & $(46,600)$ & -- \\
\hline & YR at CS & 25.31 & 10.16 & 14.05 & 17.65 & 46,600 & 64 \\
\hline \multirow[t]{2}{*}{$2 / 27 / 90$} & YR at QW & 41.43 & 15.72 & 18.71 & 26.73 & $(24,100)$ & -- \\
\hline & YR at CS & 43.55 & 15.85 & 19.67 & 27.22 & 24,100 & 49 \\
\hline \multirow[t]{2}{*}{$5 / 16 / 90$} & YR at QW & 14.87 & 4.92 & 12.81 & 10.31 & $(111,000)$ & -- \\
\hline & YR at CS & 15.62 & 4.99 & 13.31 & 10.47 & 111,000 & 67 \\
\hline \multirow[t]{8}{*}{$9 / 28 / 90$} & $\mathrm{BC}$ us springs & 5.35 & 0.56 & 10.58 & 5.06 & $710 \mathrm{e}$ & -- \\
\hline & YR us BC & 16.20 & 8.35 & 9.24 & 17.50 & $(39,600)$ & -- \\
\hline & YR ds BC & 16.38 & 8.42 & 9.32 & 17.40 & $(40,310)$ & 17 \\
\hline & YR us GR & 16.39 & 8.27 & 9.34 & 16.86 & $(40,310)$ & 0 \\
\hline & GR at YR & 116.4 & 31.17 & 65.45 & 29.36 & 3,290 & -- \\
\hline & YR ds GR & 24.45 & 10.04 & 13.84 & 17.89 & $(43,600)$ & 26 \\
\hline & YR us QW & 24.47 & 10.12 & 13.92 & 18.15 & $(43,600)$ & 0 \\
\hline & YR at CS & 26.36 & 10.20 & 14.57 & 18.64 & 43,600 & 66 \\
\hline
\end{tabular}

${ }^{1}$ Samples collected at two or more points across stream were mixed to yield an integrated sample for each site. Refer to 2 figure G-2 for map of site locations.

${ }_{3}^{2}$ Concentrations reported to one significant number more than warranted by precision of laboratory analysis.

3 Assumed values shown in ( ); streamflow values for YR at QW assumed equal to values for YR at CS; value for GR at YR assumed equal to value at 45th parallel bridge gaging station (Gardner River near Mammoth) plus $30 \mathrm{~L} / \mathrm{s}$; value for YR ds BC assumed equal to value for YR at CS minus GR at YR; value for YR us BC assumed equal to value for YR ds $B C$ minus $B C$ us springs; value for $B C$ us springs based on visual estimate by R.H. Mariner, U.S. Geological Survey.

${ }^{4}$ Calculated from equation 1 in text, using the difference in dissolved sulfate between adjacent sites and assumed sulfate concentrations in Bear Creek-type thermal water of $869 \mathrm{mg} / \mathrm{L}$ (for all sites upstream of YR us QW) and an assumed sulfate concentration in La Duke-type thermal water of $1250 \mathrm{mg} /$ (for all sites downstream of YR us QW). 
Table G-5. Selected data for wells in Corwin Springs KGRA obtained during this study. Locations given in figure $\mathrm{G}-2$

[m, meters; mg/L, milligrams per liter]

\begin{tabular}{|c|c|c|c|c|c|c|}
\hline $\begin{array}{l}\text { Well } \\
\text { number }\end{array}$ & $\begin{array}{l}\text { Well name } \\
\text { or owner }\end{array}$ & $\begin{array}{c}\text { Drilled } \\
\text { depth } \\
(\mathrm{m})\end{array}$ & $\begin{array}{c}\text { Depth to } \\
\text { water } \\
(\mathrm{m})\end{array}$ & $\begin{array}{c}\text { Maximum } \\
\text { temperature }^{2} \\
\text { (Celsius) }\end{array}$ & $\begin{array}{l}\mathrm{SO}_{4} \\
(\mathrm{mg} / \mathrm{L})\end{array}$ & $\mathrm{SO}_{4} / \mathrm{Cl}$ \\
\hline 1 & CUT geothermal & 140 & 11 & 57 & 1228 & 33 \\
\hline 2 & Miller geothermal & 59 & 12 & 24 & 1001 & 27 \\
\hline 3 & U'ren & 62 & $\mathrm{~nm}$ & $27(\mathrm{p})$ & 259 & 19 \\
\hline 4 & RTR East Gate & 27 & 16 & 9 & 92 & 12 \\
\hline 5 & RTR Spring Creek & 70 & 25 & 13 & 271 & 29 \\
\hline 6 & NPS & 27 & 14 & 9 & 94 & 5 \\
\hline 7 & Bill Hoppe & 55 & 40 & 10 & 1522 & 63 \\
\hline 8 & Dan Creek & 45 & $\mathrm{~nm}$ & $9(p)$ & 162 & 32 \\
\hline 9 & Ken Ballagh & 89 & 30 & 11 & 112 & 7 \\
\hline 10 & Jack McPherson & 75 & 60 & $12(p)$ & 25 & 3 \\
\hline
\end{tabular}

${ }^{1}$ Average of available measurements; $\mathrm{nm}$ signifies not measured.

${ }^{2}$ From temperature log or produced-fluid temperature (p). 
Table G-6. Total discharge of Clearwater Springs based on the difference in chloride flux between monitoring sites on Obsidian Creek downstream from Clearwater Springs and upstream from Clearwater Springs in Yellowstone National Park

Sample Date: Listed by year, month, and day.

$\Delta$ : Difference between downstream and upstream sites.

Chloride Flux: Discharge times chloride concentration.

Thermal Discharge: Chloride flux divided by $470 \mathrm{mg} / \mathrm{L}$.

$[\mathrm{L} / \mathrm{s}$, liters per second; $\mathrm{mg} / \mathrm{L}$, milligrams per liter; $\mathrm{g} / \mathrm{s}$, grams per second; * , no data]

\begin{tabular}{|c|c|c|c|c|c|}
\hline $\begin{array}{l}\text { Sample } \\
\text { Date }\end{array}$ & $\begin{array}{c}\Delta \\
\text { Temperature } \\
\text { (Celsius) }\end{array}$ & $\begin{array}{c}\Delta \\
\text { Discharge } \\
(\mathrm{L} / \mathrm{s})\end{array}$ & $\begin{array}{c}\Delta \\
\text { Chloride } \\
(\mathrm{mg} / \mathrm{L})\end{array}$ & $\begin{array}{c}\Delta \\
\text { Chloride Flux } \\
(\mathrm{g} / \mathrm{s})\end{array}$ & $\begin{array}{c}\text { Thermal } \\
\text { Discharge } \\
(\mathrm{L} / \mathrm{s})\end{array}$ \\
\hline 880804 & -0.5 & 15.0 & 32 & 4.8 & 10.2 \\
\hline 880812 & 0.5 & 3.4 & 30 & 1.5 & 3.2 \\
\hline 880818 & 1.0 & 15.5 & 37 & 5.0 & 10.6 \\
\hline 880825 & 1.0 & 12.8 & 33 & 4.2 & 8.9 \\
\hline 880901 & 1.0 & 11.7 & 28 & 3.9 & 8.3 \\
\hline 880923 & 3.5 & 10.8 & -48 & 1.9 & 4.0 \\
\hline 881009 & 4.5 & 10.2 & 11 & 2.9 & 6.2 \\
\hline 881014 & 3.0 & 8.8 & $\star$ & $\star$ & $\star$ \\
\hline 881022 & 5.0 & 7.7 & * & * & * \\
\hline 881027 & 5.0 & 6.5 & $\star$ & $\star$ & * \\
\hline 881103 & 11.0 & 11.3 & 51 & 4.4 & 9.4 \\
\hline 881110 & 5.5 & 10.5 & 39 & 3.9 & 8.3 \\
\hline 881212 & 4.0 & 7.4 & 46 & 3.3 & 7.0 \\
\hline 890208 & 7.0 & 7.4 & 52 & 3.2 & 6.8 \\
\hline 890302 & 3.0 & 0.5 & 35 & 1.2 & 2.6 \\
\hline 890420 & 3.0 & 6.8 & 7 & 1.5 & 3.2 \\
\hline 890518 & * & 39.4 & 7 & 3.6 & 7.7 \\
\hline 890601 & 10.0 & 19.3 & 14 & 3.1 & 6.6 \\
\hline 890613 & 5.0 & 3.4 & 34 & 2.9 & 6.2 \\
\hline 890626 & $\star$ & * & 35 & * & $\star$ \\
\hline 890724 & 8.0 & 9.6 & 44 & 3.4 & 7.2 \\
\hline 890822 & 3.5 & 10.2 & 48 & 3.6 & 7.7 \\
\hline 890919 & 6.5 & 10.2 & 32 & 3.2 & 6.8 \\
\hline 891017 & $\star$ & 8.2 & 37 & 2.9 & 6.2 \\
\hline 891121 & * & 8.8 & 39 & 3.3 & 7.0 \\
\hline 891215 & 9.0 & 8.0 & 43 & 3.3 & 7.0 \\
\hline 900216 & -3.5 & 4.8 & 26 & 2.0 & 4.3 \\
\hline 900330 & 21.2 & 10.8 & 42 & 3.8 & 8.1 \\
\hline 900613 & * & 4.8 & 26 & 2.7 & 5.7 \\
\hline $\mathrm{N}$ & 24 & 28 & 26 & 25 & 25 \\
\hline MEAN & 4.9 & 10.1 & 30 & 3.1 & 6.5 \\
\hline STD DEV & 4.9 & 7.0 & 20 & 1.1 & 2.5 \\
\hline MINIMOM & -3.5 & 0.5 & -48 & 1.2 & 2.6 \\
\hline MAXIMON & 21.2 & 39.4 & 52 & 5.0 & 10.6 \\
\hline
\end{tabular}


Table G-7. Partial chemical analyses for spring BC-1 at Bear Creek Springs in the Corwin Springs KGRA and for Sheepeater Canyon Hot Spring in Yellowstone National Park

Sample Date: Listed by year, month, and day.

Laboratory: UURI, University of Utah Research Institute Earth Science Laboratory, Salt Lake City, Utah; CL, U.S. Geological Survey Central Laboratory, Arvada, Colorado; YK, U.S. Geological Survey laboratory, Menlo Park, California, under the direction of Y.K. Kharaka.

[mg/L, milligrams per liter; $\mu \mathrm{S} / \mathrm{cm}$, microsiemens per centimeter; * , no data]

\begin{tabular}{ccccccc}
\hline $\begin{array}{c}\text { Sample } \\
\text { Date }\end{array}$ & $\begin{array}{c}\text { Sample } \\
\text { Time } \\
\text { (hour) }\end{array}$ & $\begin{array}{c}\text { Water } \\
\text { Temperature } \\
\text { (Celsius) }\end{array}$ & $\begin{array}{c}\text { Chloride } \\
(\mathrm{mg} / \mathrm{L})\end{array}$ & $\begin{array}{c}\text { Sulfate } \\
(\mathrm{mg} / \mathrm{L})\end{array}$ & $\begin{array}{c}\text { Conduct- } \\
\text { ance } \\
(\mu \mathrm{S} / \mathrm{cm})\end{array}$ & $\begin{array}{c}\text { Labo- } \\
\text { ratory }\end{array}$ \\
\hline
\end{tabular}

Bear Creek Spring

\begin{tabular}{|c|c|c|c|c|c|c|}
\hline 880805 & 1300 & 31.0 & 40 & 758 & 3210 & UURI \\
\hline 880811 & $\star$ & $\star$ & 40 & 758 & 2880 & UURI \\
\hline 880819 & 1200 & 31.5 & 41 & 737 & 3100 & UURI \\
\hline 880826 & 930 & 31.0 & 40 & 804 & 2600 & UURI \\
\hline 880902 & 930 & 30.0 & 39 & 756 & 2500 & UURI \\
\hline 880915 & 1000 & 31.7 & 36 & 790 & 2690 & CL \\
\hline 880915 & 1000 & 31.7 & 40 & 745 & 2400 & UURI \\
\hline 880923 & 1020 & 32.5 & 40 & 740 & 2350 & UURI \\
\hline 881006 & 930 & 32.0 & 40 & 785 & * & UURI \\
\hline 890104 & 1500 & 31.5 & 44 & 770 & 2200 & DURI \\
\hline 890426 & 1100 & 32.0 & 46 & 908 & 2500 & UURI \\
\hline 890601 & 1400 & 33.0 & 47 & 1130 & 2900 & UURI \\
\hline 890620 & * & $\star$ & 42 & 869 & 2880 & $\mathbf{Y K}$ \\
\hline 890909 & * & * & 42 & 824 & 2650 & $\mathbf{x}$ \\
\hline 891124 & 1400 & 32.0 & 42 & 793 & 2900 & UURI \\
\hline 900326 & 1100 & 32.0 & 46 & 915 & 2330 & OURI \\
\hline MEAN & & 31.7 & 42 & 818 & 2673 & $\star$ \\
\hline STANDARD & DEVIAIION & 0.7 & 2.9 & 101 & 298 & $\star$ \\
\hline MINIMUM & & 30 & 36 & 737 & 2200 & $\star$ \\
\hline MAXIMUM & & 33 & 47 & 1130 & 3210 & $\star$ \\
\hline
\end{tabular}

Sheepeater Canvon Hot Soring

\begin{tabular}{|c|c|c|c|c|c|c|}
\hline 880812 & * & * & 116 & 84 & 1270 & UURI \\
\hline 880819 & * & $\star$ & 101 & 77 & 1280 & UURI \\
\hline 880915 & * & * & 124 & 83 & 1200 & UURI \\
\hline 890113 & 1200 & 73.0 & 99 & 83 & 1100 & UURI \\
\hline 890626 & $\star$ & $\star$ & 97 & 85 & 1260 & TURI \\
\hline 891228 & 1330 & 72.5 & 97 & 89 & 1200 & UURI \\
\hline 900330 & 1100 & 72.0 & 95 & 91 & 1300 & UURI \\
\hline MEAN & & 72.5 & 104 & 85 & 1230 & * \\
\hline STANDARD & DEVIATION & 0.5 & 11 & 4.5 & 69 & * \\
\hline MUNIMOM & & 72.0 & 95 & 77 & 1100 & * \\
\hline MaxIMOM & & 73.0 & 124 & 91 & 1300 & * \\
\hline
\end{tabular}




\title{
CHAPTER H
}

\section{EFFECTS OF POTENTIAL GEOTHERMAL DEVELOPMENT}

\author{
By Michael L. Sorey
}

\section{Contents}

Page

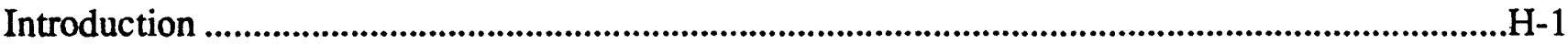

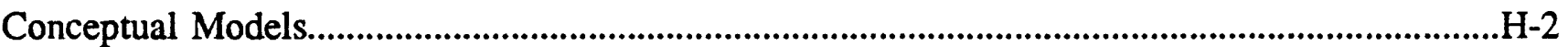

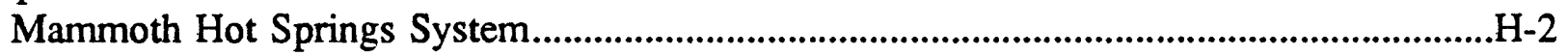

La Duke and Bear Creek Systems..........................................................................................

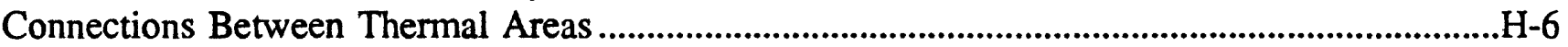

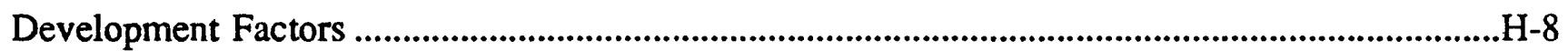

Geothermal Fluid Production Limited to the Natural Thermal-Water Discharge .................H-9

Geothermal Fluid Production Exceeding the Natural Thermal-Water Discharge ...............H-10

Injection of Produced Fluid ............................................................................................

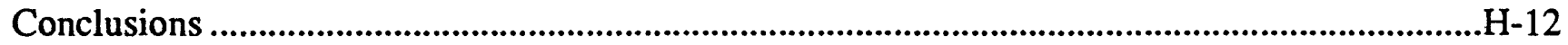

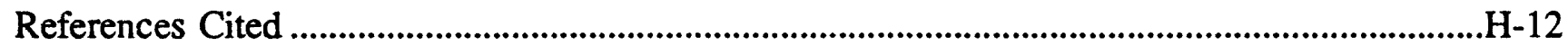

\section{Introduction}

In this section of the report, the results of our scientific investigations are used to address the three principal issues of our study - (1) sources of thermal water for hot spring areas, (2) subsurface connections between thermal areas, and (3) effects of geothermal development on thermal features. The key question is whether future geothermal development in the Corwin Springs KGRA could affect thermal features in Yellowstone National Park. The answer depends on whether hydraulic connections exist between these areas and on the locations and scales of future developments.

Our study focussed on potential effects of geothermal development on the surficial thermal features in the Mammoth area, although the entire Park is currently listed as a significant thermal feature in the Federal Register notice of August 3,1987. The intent of this designation was to include all thermal features connected to the Yellowstone hydrothermal system, as listed under seven groups of features. This list includes Mammoth Hot Springs. If thermal aquifers that may exist beneath the north boundary of the Park are considered part of the Yellowstone hydrothermal system, then changes in head in such aquifers could be viewed as adverse effects to be considered following the guidelines set forth in Geothermal Steam Act Amendments accompanying Public Law 100-443. One such effect could be a decrease in thermal-water discharge to the Yellowstone River in the vicinity of Bear Creek Springs where the river is inside the Park boundary. 


\section{Conceptual Models}

Previous sections of the report describe the general geologic, hydrologic, and geochemical conditions affecting the main thermal features in the study area: at Norris Geyser Basin and Clearwater Springs, Mammoth Hot Springs and Hot River, Bear Creek Springs, and La Duke Hot Spring. The lack of subsurface information from wells prevented delineation of actual recharge areas and flow paths that supply thermal water to each of these areas. As illustrated in the block diagram in figure $\mathrm{H}-1$, a common feature of these systems is flow through pre-Cretaceous sedimentary rocks in the Gardiner syncline, where reservoirs for thermal fluids and sources of dissolved chemicals are most likely found in Paleozoic carbonate rocks, such as the Mission Canyon Limestone (Pierce and others, this volume). Stratigraphic and hydrologic relations favor an overall south-to-north direction for ground-water flow in the syncline from Mammoth toward the Gardiner fault. Reservoir-temperatures, which can only be estimated from chemical-geothermometer calculations, range from $100^{\circ} \mathrm{C}$ for Mammoth thermal water to $80^{\circ} \mathrm{C}$ and $70^{\circ} \mathrm{C}$ for La Duke and Bear Creek thermal water, respectively (Kharaka and others, this volume). These results are consistent with a northerly trending flow system in the Gardiner syncline. Minimum depths of circulation required to reach these temperatures, based on heat flow and temperature gradients expected in the absence of shallow magmatic heat sources, range from 2-3 km. The Paleozoic carbonate rocks occur at such depths under the Sepulcher structural low west of Mammoth and beneath the axis of the Yellowstone River Valley between Bear Creek and La Duke (fig. C-2).

\section{Mammoth Hot Springs System}

Beneath the Mammoth area, thermal fluid is derived from some combination of lateral flow moving northward in the Norris-Mammoth corridor and deep circulation originating from more local sources (for example, the Gallatin Range to the west). Chemical and isotopic evidence for each of these possibilities is discussed by Kharaka and others (this volume). Similar ratios of conservative constituents, relatively high $\mathrm{Cl}$, and shifts in oxygen-18 from the meteoric-water line are observed in thermal waters at Norris, Clearwater, and Mammoth. This suggests that Mammoth-type thermal water could be derived by mixing about $30-40$ percent Norris water with $60-70$ percent low-salinity meteoric water. However, differences in the rates and compositions of gas discharge from Mammoth Hot Springs and thermal areas between Mammoth and Norris argue for a source of magmatic volatiles (and heat) that is independent of the main Yellowstone hydrothermal system. Kharaka and others (this volume) suggest that a separate magmatic source could exist beneath Mammoth Hot Springs because the highest helium-isotope ratios, gas discharges, and heat fluxes are obtained there.

The most significant aspect of the Mammoth geothermal system is its rate of heat and fluid discharge. For a total flow of $590 \mathrm{~kg} / \mathrm{s}$ attaining a temperature of $100^{\circ} \mathrm{C}$, the indicated convective heat output is $2.5 \times 10^{8} \mathrm{~W}$. This is within the range of convective heat flow values calculated for Norris $(2-4 \times 10$ W) by Fournier and others (1976). Such a high rate of heat flow together with elevated helium-isotope ratios (Kharaka and others, this volume), indicate that inputs of magmatic heat and volatiles occur somewhere within the Mammoth hydrothermal system. Heat-balance calculations show that it is not possible to provide this rate of heat input in a localized flow system 


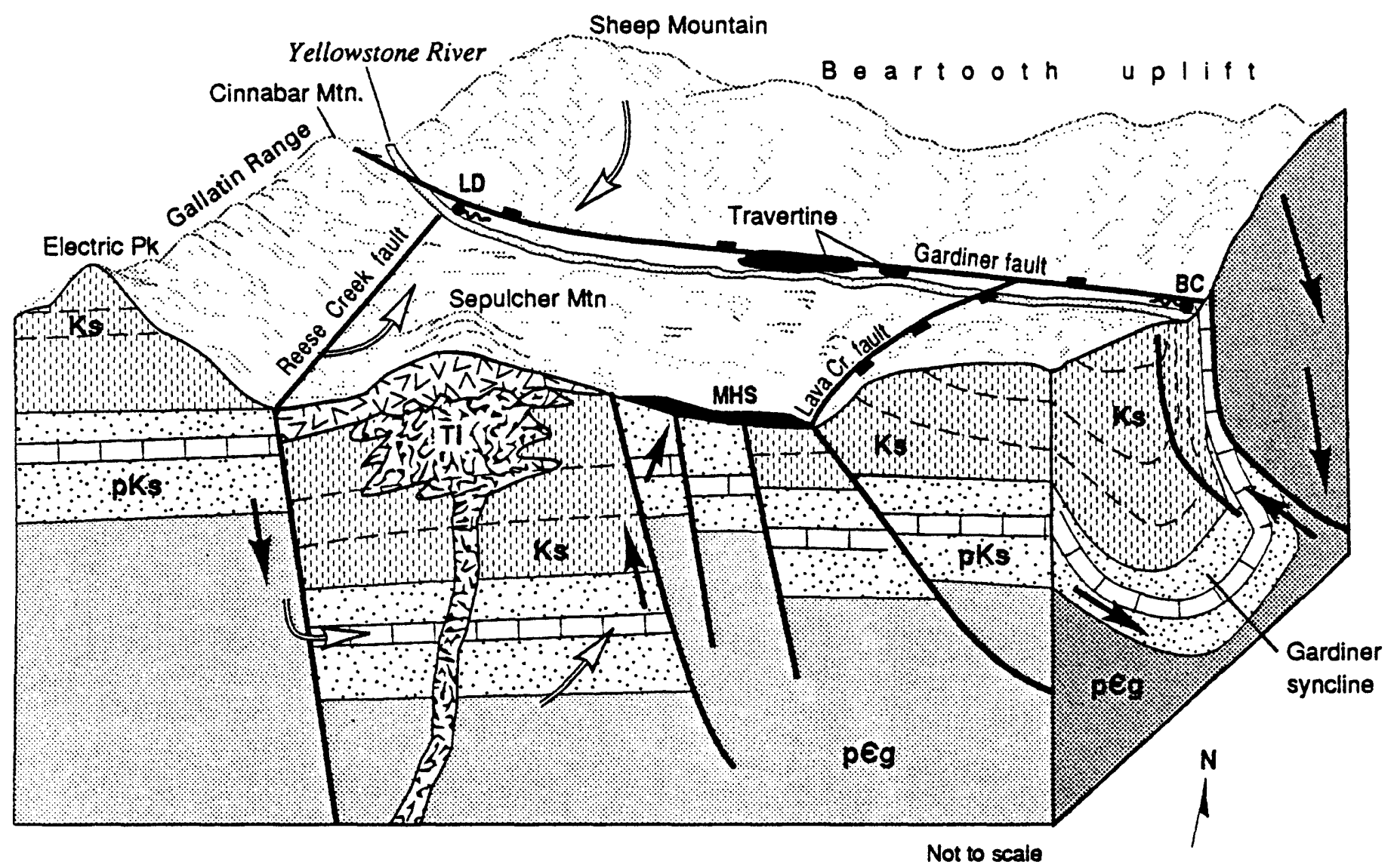

Figure H-1. Conceptual model of possible flow systems associated with thermal areas at Mammoth Hot Springs (MHS), Hot River (HR), Bear Creek Springs (BC), and La Duke Hot Spring (LD). Arrows indicate general directions of fluid flow (solid in exposed planes of the diagram and open along zones unseen in exposed planes of the diagram). Faults shown as heavy solid lines, with block teeth on overriding plate of reverse faults. Simplified stratigraphic units are labeled Ks (Cretaceous sedimentary rocks), pKs (pre-Cretaceous sedimentary rocks), Tvc (Tertiary volcaniclastic rocks), Ti (Tertiary intrusives), and p€g (Precambrian gneiss and schist). Approximate position of the Mission Canyon Limestone is shown by blocky pattern. 
of limited areal extent $\left(<100 \mathrm{~km}^{2}\right)$, unless a long-lived magma chamber exists at relatively shallow depths beneath the Mammoth area or fluid circulation extends down to depths on the order of 10 kilometers.

Interpretations of electrical geophysical soundings indicate that partial-melt conditions exist at depths below about $6 \mathrm{~km}$ in the Norris-Mammoth corridor south of Bunsen Peak (Stanley and others, this volume). North of Bunsen Peak, the electrical sounding data do not show evidence of magmatic conditions at depths less than about $10 \mathrm{~km}$ in the Mammoth area, but interpretations are limited by sparse sounding locations (Stanley and others, this volume).

Heat-balance calculations applied to a flow of high-temperature $\left(300^{\circ} \mathrm{C}\right)$ thermal water from Norris to Mammoth indicate that most of the heat and about 40 percent of the fluid for the Mammoth system could originate from Norris, provided flow from Norris to Mammoth occurred in permeable zones at depths sufficient to minimize conductive cooling $(2-3 \mathrm{~km})$. These mixing proportions are close to those indicated by the conservative constituent ratios. The geophysical results and the heat-balance considerations indicate that there is a component of flow in the Mammoth system originating from southerly sources in the Norris-Mammoth corridor, although not necessarily from as far south as Roaring Mountain or Norris as postulated by White and others (1988) and Fournier (1989).

Upflow of thermal fluid beneath the Mammoth area could be associated with conduits provided by the Mammoth fault, by the Swan Lake fault, and/or by north-south trending faults east of Terrace Mountain (Pierce and others, this volume). Similarities in strontium-isotope ratios of travertine in older deposits at Terrace Mountain, Snow Pass, and Pinyon Terrace and of the active terraces at Mammoth indicate that present-day discharge at Mammoth and Hot River is derived by lateral flow of thermal water through the travertine and underlying sedimentary rocks from upflow zones located to the west of the active spring vents.

\section{La Duke and Bear Creek Systems}

Several conceptual models are possible for flow systems and reservoir rocks supplying thermal water to La Duke Hot Spring and Bear Creek Springs. These models include (1) flow from the south along permeable zones associated with the northward-trending East Gallatin-Reese Creek fault system and other north and northeast-trending faults, (2) flow from the south through Paleozoic carbonate rocks within the gently dipping southern limb of the Gardiner syncline, and (3) flow from the north through Precambrian rocks of the Beartooth uplift and/or from more local sources within the Gardiner fault or the vertical limb of the Gardiner syncline. The geochemical data set indicate that thermal-water chemistry at La Duke and Bear Creek is influenced by low-temperature $\left(<100^{\circ} \mathrm{C}\right)$ interactions with carbonate rocks and Precambrian metamorphic rocks. Both types of rocks occur in the vicinity of the Gardiner reverse fault and in the vertical limb of the Gardiner syncline, so the chemical characteristics of these thermal waters could be attainable from a flow system localized along the Gardiner fault. However, heat-balance considerations based on total thermal-water discharge estimates of 61 and $17 \mathrm{~L} / \mathrm{s}$ for the La Duke and Bear Creek areas, respectively, indicate that the areal extents of flow systems supplying these features are more regional in scale $\left(\sim 100 \mathrm{~km}^{2}\right)$ 
and hence probably not confined to the Gardiner fault zone.

The geochemical and isotopic data are useful in assessing the likelihood of hydraulic connections between thermal features in the KGRA and at Mammoth, but do not allow us to delineate actual flow paths and recharge areas for each hydrothermal system. For example, the stable water-isotope data set is consistent with recharge in the Gallatin Range or the Beartooth uplift for the KGRA thermal waters. Oxygen-isotope values for the KGRA thermal waters are not shifted from the meteoric-water line, whereas values for thermal water from Mammoth Hot Springs are. This lack of oxygen shift could be due either to long residence-time flow through the Precambrian rocks of the Beartooth uplift and short residence-time flow through carbonate rocks in upflow zones adjacent to the Gardiner fault, or to lower reservoir temperatures in hydrothermal systems supplying thermal features in the KGRA (Kharaka and others, this volume). In the vicinity of La Duke Hot Spring, thermal features with similar water chemistry are aligned along segments of the Reese Creek fault system, indicating that intersections of these north-trending faults with the vertical limb of the Gardiner syncline or the Gardiner fault are important in localizing and transmitting upflow through the fine-grained valley fill deposits (Pierce and others, and Hamilton and others, this volume).

Other indirect indications of zones of thermal-water flow that could be associated with hydrothermal systems in the KGRA are provided by electrical geophysical data, soil-mercury and streambed-temperature data, and the distribution and isotopic characteristics of travertine deposits. Similarities in strontium-isotopic values in travertine on the Gardiner bench above Gardiner and at Rattlesnake mound south of Bear Creek Springs with travertines at Mammoth Hot Springs and Terrace Mountain support the concept of previous high thermal-water flow rates from the Mammoth hydrothermal system to the vicinity of the Gardiner fault (Pierce and others, Kharaka and others, this volume). Several zones of deep-seated low resistivity along north and northeast-trending faults near the northern boundary of the Park (Stanley and others, this volume) reflect intense hydrothermal alteration along flow paths that may have been active during these previous periods of travertine deposition. Strontium-isotopic values for water and travertine being deposited today at Bear Creek Springs and La Duke Hot Spring differ from the values noted above, indicating that the flow systems and reservoir rocks supplying these features are at least in part different from flow systems active during previous flow periods.

The magnetotelluric-sounding data reflect intense hydrothermal alteration along the Reese Creek fault near the Park boundary down to depths of at least $3 \mathrm{~km}$. This would be consistent with a hydrothermal system supplying thermal water to La Duke Hot Spring from recharge areas in the Gallatin Range to the south.

The soil-mercury and streambed-temperature data sets have been interpreted as indicating that there is a geothermal aquifer complex trending northward between Roaring Mountain and the northboundary area, with extensions to the Gardiner travertine bench, Bear Creek Springs, and La Duke Hot Spring (Hamilton and Chambers, this volume). Near Bear Creek Springs and La Duke Hot Springs, streambed-temperature anomalies of $6^{\circ}$ to $44^{\circ} \mathrm{C}$ correlate with hot springs near river level and inflows of thermal water at substantial rates detected from sulfate-flux measurements. Between Bear Creek Springs and La Duke Hot Spring, correlated mercury and streambed-temperature 
anomalies $\left(1-6^{\circ} \mathrm{C}\right)$ at several locations are inferred to signify thermal-water flow across the Park boundary in geothermal aquifers tapped by faults (Hamilton and Chambers, this volume). These interpretations cannot be confirmed without drilling, sampling, and testing wells in these areas. Existing chemical and temperature data from shallow wells in the north-boundary area do not show evidence of thermal water and suggest that weak streambed-thermal anomalies in this area could result from seepage of nonthermal ground water that is slightly warmer than river water.

Geochemical and isotopic characteristics of thermal waters sampled in the La Duke area, including those of La Duke Hot Spring and other hot springs along the banks of the Yellowstone River, and the CUT geothermal well, are virtually identical. Two other wells within a distance of $0.8 \mathrm{~km}$ south of La Duke Hot Spring tap thermal water at temperatures $\geq 24^{\circ} \mathrm{C}$ that may be a mixture of La Duke-type thermal water and more dilute ground water (Sorey and others, this volume). This indicates that the area encompassed by these thermal features represents all or part of the discharge area for the same hydrothermal system.

Significant differences in chemical characteristics and stable-isotope values are observed among springs with temperatures of $15^{\circ}-33^{\circ} \mathrm{C}$ at Bear Creek Springs. However, most of the thermal-water discharge is of uniform composition and probably is derived from the same flow system (Kharaka and others, this volume). Tritium contents of the hottest Bear Creek springs indicate that the thermal water contains 25-50 percent ground water post-1960 in age, and hence of relatively local origin. Thermal waters at La Duke Hot Spring and Mammoth Hot Springs contain no tritium.

\section{Connections Between Thermal Areas}

Thermal waters from La Duke Hot Springs and the CUT geothermal well show significant differences from thermal waters at Mammoth Hot Springs in terms of (1) ratios of conservative constituents, (2) pressures of dissolved $\mathrm{CO}_{2}$, (3) water isotope values, and (4) isotopes of helium, strontium, boron, and lithium (Kharaka and others, this volume). These differences are consistent with the existence of separate hydrothermal systems for La Duke and Mammoth, involving reactions with different reservoir rocks under different thermodynamic conditions. The water-isotope data and relatively high chloride concentration $(170 \mathrm{mg} / \mathrm{L})$ show that thermal water from the Mammoth system has undergone high-temperature water/rock reactions, whereas the La Duke (and Bear Creek) thermal water has not. The helium-isotope data show a significant mantle-derived helium component in Mammoth thermal water but virtually none in La Duke thermal water. Although mixing-model calculations of the percentage of Mammoth-type water that could be in La Duke Hot Spring are subject to some uncertainty, the results are consistent with at most a 5 percent Mammothtype component, and most likely no Mammoth-type component, in La Duke Hot Spring water (Kharaka and others, this volume).

The hottest thermal waters at Bear Creek Springs have similar major element chemistry to that of Mammoth Hot Spring waters, except for chloride concentration, which is only $43 \mathrm{mg} / \mathrm{L}$ at Bear Creek (compared with $170 \mathrm{mg} / \mathrm{L}$ at Mammoth). Ratios of conservative constituents are similar at 
each area, but Bear Creek thermal water shows no oxygen shift. This indicates that thermal water from both areas has been influenced by the same low-temperature processes and reservoir rock types, but that Mammoth water first undergoes high-temperature rock/water reactions. Strontium, boron, and lithium isotopic values for Bear Creek thermal water are substantially different from those for Mammoth water, indicating that although the low-temperature rock/water reactions are similar, the rocks that are the source of these constituents are different. Alternatively, the chemical constituents in the hottest Bear Creek thermal water could be derived from the Mammoth system by mixing Mammoth water with three parts dilute cold water, reheating, and dissolving additional major ions (for example $\mathrm{Ca}$ and $\mathrm{SO}_{4}$ ). Mixing-model calculations using water-isotopes and isotopes of helium, boron, and lithium, are consistent with a $10 \pm 10$ percent Mammoth component in Bear Creek Springs, but do not prove that such a component exists.

A distinction was made in Pierce and others (this volume) between hydrogeologic and hydraulic connections between thermal areas. As used in this report, a hydrogeologic connection requires a continuous permeable zone, or aquifer, between thermal areas, whereas a hydraulic connection includes the additional aspect of a positive head gradient that transmits water through the aquifer. If a hydraulic connection exists between two thermal areas, we would expect to find chemical evidence of fluid from the upstream hydrothermal system in the downstream thermal features. The geochemical and isotopic considerations discussed above imply that there is little or no hydraulic connection between the Mammoth hydrothermal system and La Duke Hot Spring, and at most only a weak hydraulic connection between the Mammoth hydrothermal system and Bear Creek Springs. This may be because hydrogeologic connections (continuous permeable pathways) do not exist between these areas or because the existing distribution of hydraulic head beneath the northern part of the study area effectively prevents or restricts thermal water from the Mammoth system from reaching La Duke Hot Spring and Bear Creek Springs. The latter could be the case if the proximity of high-altitude recharge areas to La Duke and Bear Creek causes higher heads in the thermal reservoirs beneath these areas than in adjacent aquifers that may transmit thermal water northward from the Mammoth area. The distinction between these two situations is important because fluid production for geothermal development that resulted in large head declines could conceivably change the existing head distribution enough to establish a hydraulic connection between areas not currently connected or to enhance an existing hydraulic connection, provided permeable pathways exist.

There exists an overall difference in elevation between hot springs at Mammoth and La Duke of about $450 \mathrm{~m}$, and between Mammoth and Bear Creek Springs of $380 \mathrm{~m}$ (fig. B-2), to drive flow northward from the Mammoth hydrothermal system to these areas. Permeable carbonate rocks extend between Mammoth Hot Springs and the Gardiner fault in the Gardiner syncline. The inference from the geochemical and isotopic data that such flow does not occur or is relatively small in magnitude, in spite of these head differences, could mean that barriers exist in the form of zones of low-permeability or stratigraphic discontinuities along faults occur between Mammoth Hot Springs and Corwin Springs KGRA. However, large head differences do not necessarily imply geologic barriers, as evidenced by the hydraulic connection between the Mammoth Terraces and Hot River, for which the head difference is about $280 \mathrm{~m}$ over a distance of $2 \mathrm{~km}$. 
The role of faults in enhancing or disrupting thermal-water flow northward from the Mammoth area is poorly understood. There is clear evidence from electrical geophysical data of deep-seated hydrothermal alteration along several faults near the north boundary of the Park that most likely results from thermal-water flow at present or in the past. Hydraulic connections, possibly faultrelated, between the Mammoth hydrothermal system and areas of extensive travertine deposits along the Gardiner fault west and south of Bear Creek Springs appear to have existed during glacial times (Pierce and others, and Kharaka and others, this volume). The Mammoth to Bear Creek connection, suggested by our chemical and isotopic data, may be a remnant of this older and more active flow system.

All factors considered, we conclude that a hydrogeologic connection between Mammoth Hot Springs and La Duke Hot Spring is possible and that the apparent lack of Mammoth-type thermal water in La Duke Hot Spring could be due to the existing head distribution. A similar situation is possible between Mammoth and Bear Creek.

\section{Development Factors}

Exploitable geothermal resources have been demonstrated to exist near La Duke Hot Spring, but may also exist elsewhere in the Corwin Springs KGRA. Reservoir temperatures are likely to be less than or equal to those estimated from chemical geothermometer calculations $\left(80^{\circ} \mathrm{C}\right.$ for $\mathrm{La}$ Duke Hot Spring and $70^{\circ} \mathrm{C}$ for Bear Creek Springs). Exploitation could involve either production of thermal water from wells, extraction of heat but not fluid from wells using downhole heat exchangers, or diversion of hot-spring discharge. Unmanipulated diversion of natural hot-spring discharge would pose no risk of adverse effects to thermal features in Yellowstone National Park. The Church Universal and Triumphant holds the preeminent water right to La Duke Hot Spring and thus could divert its flow for use on the Royal Teton Ranch (Montana Department of Natural Resources and Conservation, written communication, 1989). This water right totals $328 \mathrm{~L} / \mathrm{s}$ and far exceed the flow of La Duke Hot Spring; it does not as yet include a right to change the point of diversion from the spring to a geothermal well.

The use of downhole heat exchangers in wells tapping geothermal reservoirs offers a mechanism for removal of heat without production of geothermal fluids. Water from another source is required to circulate through the heat exchanger. This type of development method does not affect the head distribution in any significant way and would present no risk of affecting the Park's thermal features. The heat extracted from the reservoir in such a development is supplied by heat stored locally in the reservoir rocks.

For geothermal development involving production of thermal water from wells, factors that need to be considered in evaluating the effects on thermal features in Yellowstone National Park include the capacities and locations of production wells, whether produced fluids are reinjected to minimize reservoir drawdown, and whether reservoir drawdown could create or enhance hydraulic connections with the Park's thermal areas. These factors, along with the hydraulic properties of the reservoir, influence the distribution of reservoir drawdown and resultant effects on thermal features. 


\section{Geothermal Fluid Production Limited to the Natural Thermal-Water Discharge}

Geothermal development that resulted in relatively small, localized drawdown of production reservoirs would pose no risk of adverse effects, such as decreased spring flow, in the Mammoth Hot Springs area. This is true whether or not hydraulic connections exist between the development area and Mammoth Hot Springs. One way to assure that drawdown would be small and localized is to limit production to areas of natural thermal-water discharge and to rates less than this discharge. It is also necessary that production be obtained from the same reservoir that feeds the natural thermal features. Such production would in large part capture the natural thermal-water discharge. Under these conditions, changes would still tend to spread throughout the reservoir, but would remain small within the development area and decrease away from the development area.

When in use, the CUT geothermal well produces from the same zone that feeds La Duke Hot Spring, as evidenced by the reduction in flow of this spring during the 1986 flow test on this well. Sustained production from the well at rates near the flow of La Duke Hot Spring $(5-9 \mathrm{~L} / \mathrm{s})$ would effectively divert the flow of the spring to the well, resulting in relatively little reservoir drawdown. Such production poses no risk of adverse effects to thermal features in Yellowstone National Park.

Production from the CUT geothermal well at rates near $25 \mathrm{~L} / \mathrm{s}$, which is close to its capacity, would most likely result in diversion of more of the natural thermal-water discharge in the vicinity of La Duke Hot Spring. We have determined from four sets of measurements of sulfate flux in the Yellowstone River that $61 \pm 8.5 \mathrm{~L} / \mathrm{s}$ of La Duke-type thermal water discharges into the river upstream from Corwin Springs. The fraction of the total production from the well that would be obtained from diversion of the natural thermal-water discharge cannot be determined without additional measurements of sulfate flux in the river during production. The greater this fraction, the smaller the drawdown in the reservoir. Given the relatively small drawdown $(<5 \mathrm{~m})$ measured in the CUT well during the 1986 flow test and the similarity in chemistry between the produced fluid and La Duke Hot Spring (Hydrometrics, 1986; Kharaka and others, this volume), it is reasonable to expect that sustained production from this well at rates near $25 \mathrm{~L} / \mathrm{s}$ would be obtained largely from diversion of natural thermal-water discharge and would therefore induce only small reservoir drawdown. Under such conditions, there would also be no risk of adverse effects to thermal features in Yellowstone National Park.

Additional geothermal wells drilled in the La Duke area and completed in the same reservoir as the existing CUT geothermal well could also obtain most of their production from diversion of the natural thermal-water discharge, provided the combined production from all such wells was less than about $60 \mathrm{~L} / \mathrm{s}$. To determine that each additional well did produce from this reservoir it could be necessary to show that well discharge caused a decline in the flow of La Duke Hot Spring. If this spring were no longer flowing because of sustained production from the CUT geothermal well, the required hydraulic connection would need to be evaluated from comparison of production-fluid chemistry with the chemistry of La Duke Hot Spring and from repeated sulfate-flux measurements in the Yellowstone River. Such measurements should show a decline in thermal-spring input to the river that is close to the rate of well production. It should be noted, however, that the accuracy of such determinations would decrease as the rate of thermal-water inflow to the river decreased. 
Alternatively, the distribution of production-induced reservoir drawdown could be evaluated by drilling one or more observation wells near the Park boundary and conducting well flow tests.

A similar type of production-rate limit for geothermal development in the vicinity of Bear Creek Springs could minimize the chances of decreased spring flow in the Mammoth area. We estimate the rate of thermal-water discharge at Bear Creek as $17 \mathrm{~L} / \mathrm{s}$, but recommend additional sulfate-flux measurements for confirmation. Geothermal-fluid production that captured this natural thermal-water discharge would result in relatively small reservoir drawdown and pose a minimal risk to Mammoth Hot Springs. However, the resultant reduction in thermal-water discharge in the Bear Creek area may constitute an adverse impact because the area of natural discharge is in or adjacent to the Park.

For the region in the Corwin Springs KGRA between Bear Creek Springs and La Duke Hot Spring, a production limit cannot be specified at this time that would eliminate the risk of adverse effects to the Park's thermal features. There are no active thermal springs in this region and sulfateflux measurements in the Yellowstone River have not delineated significant inputs of thermal water to the river. A hydraulic connection between the Gardiner travertine bench and the Mammoth hydrothermal system is likely to have existed in the past $(>12,000$ years ago). Additional information from well drilling and testing is needed before a meaningful assessment of reservoir conditions and effects of geothermal development in this region between Bear Creek Springs and La Duke Hot Spring can be made.

\section{Geothermal Fluid Production Exceeding the Natural Thermal-Water Discharge}

For geothermal-fluid production rates exceeding the natural thermal-water discharge in the development area, reservoir drawdown is likely to be more substantial regardless of how much of the natural discharge is captured by wells. Under these conditions, detection of head changes in permeable zones beneath the Park would require a monitoring program with observation wells completed near the Park boundary. Monitor wells for this purpose must be completed in formations that are in hydraulic connection with the production reservoir. Satisfactory completion of such monitor wells would require collection and interpretation of considerable subsurface information from drilling and well testing.

The degree of reservoir head decline, or drawdown, within the Corwin Springs KGRA required to establish a hydraulic connection and cause drawdown in reservoirs beneath Mammoth Hot Springs or elsewhere in the Park cannot be determined without additional information on the distribution of hydraulic head. Such information must come from well drilling and testing. Should a hydraulic connection be established, the rate and amplitude of the spread of subsequent production-induced head changes would depend on the hydraulic properties of the associated aquifer. The only existing information on aquifer properties in the study area comes from the 13-hour production test on the CUT geothermal well in 1986 (Hydrometrics, 1986; Sonderegger, 1987). This well produced at rates near $25 \mathrm{~L} / \mathrm{s}$ from a permeable zone in bedrock of unknown composition at a depth of $128 \mathrm{~m}$ (Pierce and others and Sorey and others, this volume). Assuming that values of transmissivity $\left(1.1 \times 10^{-2} \mathrm{~m}^{2} / \mathrm{s}\right)$ and storage coefficient $(0.0028)$ from this test are applicable, simple analytical 
solutions show that induced head changes in the La Duke area could cause measurable head changes to reach Mammoth Hot Springs (14 km distant) in 0.5-1.5 years, depending on the geometric configuration of the aquifer connecting these areas. Similarly, induced head changes in the Bear Creek area ( $8 \mathrm{~km}$ from Mammoth) could cause head changes to reach Mammoth Hot Springs in only a few months. Such rapid propagation of drawdown requires that conditions of high transmissivity and low storage coefficient exist throughout the hydrogeologic connection(s) between these areas. Regionally continuous carbonate formations such as the Mission Canyon Limestone could allow such assumptions.

Under the condition of a hydraulic connection involving these same aquifer properties, the level of drawdown induced beneath the Mammoth area from geothermal fluid production in the KGRA would remain small (on the order of 10 percent or less, as determined from the simple analytical solution for radial flow in a homogenous aquifer) relative to drawdown in the production reservoir. Within the Mammoth hydrothermal system, spring flow on the Mammoth Terraces is most sensitive to changes in reservoir head because these springs occur at relatively high altitudes in the discharge area for the system. Although the amount of reservoir drawdown beneath the Mammoth Terraces that would cause a noticeable effect on hot spring flow is not known with certainty, the estimated altitude of the piezometric surface at well Y-10 ( $25 \mathrm{~m}$ above land surface) indicates that drawdown would need to be on the order of a few meters to cause noticeable effects. This corresponds with drawdown in KGRA production reservoirs of $30 \mathrm{~m}$ or more. For comparison, the drawdown in the existing CUT geothermal well produced at $25 \mathrm{~L} / \mathrm{s}$ during the 1986 flow test was about $5 \mathrm{~m}$. From this, we infer that more substantial production rates and induced drawdown in the development area are required to cause adverse effects at Mammoth Hot Springs, assuming again that a hydraulic connection were established.

\section{Injection of Produced Fluid}

An alternative method of minimizing reservoir drawdown during development is to inject some or all of the produced fluid into additional wells completed in the production reservoir. This scheme is being used in many developed geothermal fields throughout the world to increase energy recovery, minimize drawdown, and dispose of cooled geothermal fluid. Injection of all the produced fluid, after some direct-use application at the land surface, results in withdrawal of heat but no net withdrawal of fluid from the reservoir. Ideally, injection wells are located at distances from production wells sufficient to minimize both reservoir drawdown and production-well cooling. Selection of optimum well spacing for these purposes requires knowledge of the hydraulic properties of the reservoir.

In the case of the Corwin Springs KGRA, the location and extent of potential production reservoirs are virtually unknown. Depths to potential reservoir rocks such as the Paleozoic Mission Canyon Limestone may vary from $100 \mathrm{~m}$ to $2,000 \mathrm{~m}$, and permeability and stratigraphic continuity in such units may be influenced by faults. From the standpoint of protection of thermal features in Yellowstone National Park, it is essential that injection wells be completed in zones that are in hydraulic communication with production zones to prevent the spread of drawdown beneath the Park. In addition to the collection and interpretation of geologic and geochemical data, meeting this 
condition would require analysis of data from well interference tests that may need to be run for periods of weeks to months.

\section{Conclusions}

Although evaluation of geochemical and isotopic data shows that little or no thermal water from the Mammoth hydrothermal system is flowing to La Duke Hot Spring and Bear Creek Springs, the possibility that permeable flow paths exist between these areas cannot be discounted. Consequently, geothermal development anywhere in the Corwin Springs KGRA that resulted in large reservoir drawdown could conceivably cause adverse effects on thermal features in Yellowstone National Park. The safest options which would pose no discernible risk to thermal springs in the Park are to limit development to surface diversion of the natural thermal-water discharge, to use downhole heat exchangers, or to produce from only the existing geothermal well near La Duke Hot Spring. More risk is involved for greater levels of development, unless fluid production is obtained mainly from the capture of natural thermal-water discharge and reservoir drawdown in the development area remains small. For geothermal fluid production exceeding the natural thermalwater discharge, properly completed monitor wells would be needed to determine the level of drawdown in reservoirs beneath the Park. Carefully planned reinjection of produced fluids would tend to minimize the risk of undesired drawdown beneath the Park, but as with successful completion of monitor wells, additional subsurface information is required to properly carry out such an effort.

\section{References Cited}

Fournier, R.O., 1989, Geochemistry and dynamics of the Yellowstone National Park hydrothermal system: Annual Review of Earth and Planetary Science, v. 17, p. 13-53.

Fournier, R.O., White, D.E., and Truesdell, A.H., 1976, Convective heat flow in Yellowstone National Park: in United Nations Symposium on the development and uses of geothermal resources, San Francisco, California, Proceedings, v. 1. p. 731-739.

Hydrometrics, 1986, Aquifer testing and evaluation of a geothermal well at Royal Teton Ranch near Corwin Springs, Montana: Report prepared for Edward L. Francis, Royal Teton Ranch by Hydrometrics, 2727 Airport Road, Helena, Montana 59021, 37 p.

Sonderegger, J.L., 1987, Potential effects of production from a geothermal well located near La Duke Hot Spring: Montana Bureau of Mines report to Montana State Department of Health and Environmental Sciences and Department of Natural Resources and Conservation, 12 p.

White, D.E., Hutchinson, R.A., and Keith, T.E.C., 1988, The geology and remarkable thermal activity of Norris Geyser Basin, Yellowstone National Park, Wyoming: U.S. Geological Survey Professional Paper 1456, 84 p. 